TATIANA PENHARRUBIA FAGUNDES

\title{
O CONTROLE DAS CONTAS MUNICIPAIS
}

Tese de Doutorado

Orientadora: Profa. Associada Monica Herman Salem Caggiano

Universidade de São Paulo (USP)

Faculdade de Direito do Largo de São Francisco

São Paulo

2012 
TATIANA PENHARRUBIA FAGUNDES

O CONTROLE DAS CONTAS MUNICIPAIS

Tese apresentada à Faculdade de Direito do Largo de São Francisco da Universidade de São Paulo (USP) como requisito para a obtenção do título de Doutor em Direito do Estado.

Orientadora: Profa. Associada Monica Herman Salem Caggiano

São Paulo

2012 


\section{O CONTROLE DAS CONTAS MUNICIPAIS}

Tese apresentada à Faculdade de Direito do Largo de São Francisco da Universidade de São Paulo (USP) como requisito para a obtenção do título de Doutor em Direito do Estado.

Departamento de Direito do Estado.

Data de aprovação:

Banca Examinadora:

Prof.(a) Dr.(a)

Instituição:

Assinatura:

Prof.(a) Dr.(a)

Instituição:

Assinatura:

Prof.(a) Dr.(a)

Instituição:

Assinatura:

Prof.(a) Dr.(a)

Instituição:

Assinatura:

Prof.(a) Dr.(a)

Instituição:

Assinatura: 


\section{DEDICATÓRIA}

Este trabalho é dedicado à minha mãe. Exemplo. Profissional competente. Amiga. Companheira. Por seu amor incondicional e carinho em todos os momentos de minha vida.

É também dedicado ao meu pai, Nelson, por ter me ensinado a ser uma pessoa honesta, responsável e determinada, valores sem os quais este trabalho não se completaria. In memoriam. 


\section{AGRADECIMENTOS}

Escrever uma tese de Doutorado é uma tarefa difícil e demorada, que se faz solitariamente. Trocamos os finais de semana por finais de computador, as reuniões com os amigos por reuniões com os Clássicos do Direito, o convívio com pessoas queridas pela reclusão em uma sala de escritório. E isto se repete dia após dia, mês após mês, ano após ano.

Muitas pessoas, no entanto, passaram pela minha vida neste período e contribuíram para que este trabalho se concretizasse dignamente. A todas elas devo os meus sinceros agradecimentos. Por isso, passo aos agradecimentos:

Agradeço a Deus por me dar força, coragem, ânimo e determinação para realizar esta árdua tarefa.

Agradeço à Faculdade de Direito da Universidade de São Paulo, por ter me proporcionado a honra de fazer parte de sua Casa.

Agradeço aos Professores Maria Sylvia Zanella Di Pietro e Roger Stiefelmann Leal, pelas valiosas observações conferidas na fase da qualificação, que me permitiram aprimorar este trabalho.

Agradeço aos meus Professores de Doutorado, Professores Cláudio Lembo, Manoel Gonçalves Ferreira Filho, Nina Beatriz Stocco Ranieri, Ignacio Maria Poveda Velasco e José Levi Mello do Amaral Junior que, com seus ensinamentos, permitiram a expansão dos meus conhecimentos, contribuindo para a elaboração deste trabalho.

Agradeço ao Conselheiro do Tribunal de Contas do Município de São Paulo, Dr. Roberto Tanzi Braguim, pela confiança em mim depositada para a realização desta tese e no cotidiano do Tribunal. 
Agradeço à minha mãe Suelly por realizar, inúmeras vezes e, de novo, a difícil tarefa de revisão do texto e pelas diversas ocasiões em que, juntas, discutimos pontos deste trabalho.

Agradeço ao meu irmão Reynaldo, por sempre se mostrar disposto a ajudar, principalmente com a árdua questão da formatação do trabalho.

Agradeço aos meus queridos amigos Alexandre Sanson e Marcelo Mazotti, colegas de caminhada, pelo auxílio durante todos estes anos, pelas dúvidas esclarecidas, risadas trocadas e discussões jurídicas que me fizeram engrandecer.

Agradeço ao amigo Marcos Peixoto Mello Gonçalves, a ajuda com o primeiro esboço do sumário da tese, colaborando para a concretização do sonho de cursar o Doutorado.

Agradeço ao amigo e Professor da Faculdade de Direito da Universidade Mackenzie, José de Resende Junior, pela preciosa colaboração no esclarecimento de dúvidas, fazendo-me trilhar o caminho certo.

Agradeço aos também queridos Ana Cláudia e Rodrigo Scalquette e Lilian e Antônio Cecílio Pires, simplesmente por serem meus Amigos. E ao último deles, por dividir comigo, em outra Faculdade, mas com o mesmo empenho, a difícil, porém honrosa e gratificante tarefa de concluir o Doutorado.

Agradeço a todos aqueles que, de alguma forma, me incentivaram e estiveram torcendo por mim.

Agradeço, especialmente, à Professora Monica Herman Salem Caggiano, pela orientação durante o curso, pelas palavras de carinho e incentivo até a conclusão desta obra e também por ter me aberto as portas para o mundo do Magistério. 


\section{RESUMO}

Só é possível estudar o tema "O controle das contas municipais" em um Estado que apresente, em sua Constituição, o princípio da separação de Poderes como uma de suas pedras angulares.

Além de competir a cada órgão do Poder uma função típica, também reflexo da teoria da separação de Poderes de Montesquieu é o sistema de "checks and balances" pelo qual um Poder controla o outro evitando a prática dos abusos.

Em matéria de contas públicas, este controle recíproco se apresenta com o dever que o Chefe do Poder Executivo tem de prestar contas ao Poder Legislativo do uso que conferiu ao dinheiro público que, na verdade, pertence ao povo. Fala-se, portanto, na função de controle externo que o Legislativo realiza sobre as contas prestadas pelo Executivo.

Em âmbito municipal, o controle externo é exercido pela Câmara Municipal com o auxílio do Tribunal de Contas, ao qual compete o dever de elaborar um parecer prévio sobre as contas de governo anualmente prestadas pelo Prefeito e encaminhá-lo ao julgamento político da Câmara Municipal. À Corte de Contas compete, pois, o controle técnico das contas, através das fiscalizações contábil, financeira, orçamentária, operacional e patrimonial e à Câmara dos Vereadores, o controle político de tais contas.

Palavras Chave: separação de Poderes. Controle. Dever do Prefeito de prestar contas. Controle externo. Câmara Municipal. Tribunal de Contas. Controles técnico e político.

\section{ABSTRACT}


To study "The control over municipal accounts" it is mandatory that a State has the principle of separation of powers as a cornerstone of its Constitution.

Besides that each branch of Government has specific responsibilities, another reflection of Montesquieu's theory of separation of Powers is the system of checks and balances, under which each branch of government controls the other to prevent abuse of power.

In terms of public accounts, this reciprocated control is represented by the duty the Head of the Executive has to account for the destination of the public money, which belongs to the people, to the Legislative; i.e., the external control carried out by the Legislative Branch over the accounts of the Executive Branch.

At municipal level, external control is carried out by the City Council and the Court of Auditors, which has to prepare a previous opinion on the government accounts annually presented by the Mayor and send it for the political judgment of the City Council. Thus, the Court of Auditors is responsible for the technical control of the accounts, running accounting, financial, budgetary, operational and equity audits, while the City Council is responsible for the political control thereof.

Key words: Separation of Powers. Control. Accountability of Mayor. External control. City Council. Court of Auditors. Technical and political controls. 


\section{RIASSUNTO}

Si puó studiare il tema "Il controllo dei conti comunali" solo in uno Stato che nella Costituzione abbia il principio della separazione dei Poteri come una delle pietre angolari.

Oltre ad attribuire ad ogni organo di Potere una funzione tipica, anche il sistema di "checks and balances" è un riflesso della teoria della separazione dei Poteri di Montesquieu, per cui un Potere controlla un altro per evitare l'uso degli abusi.

In materia di conti pubblici, il controllo si manifesta con l'obbligo che ha il Capo del Potere Esecutivo di presentare i conti al Potere Legislativo per giustificare l'uso del denaro pubblico che è del popolo. Si parla di una funzione di controllo esterno che il potere Legislativo esercita sui conti forniti dall' Esecutivo.

In ambito comunale, il controllo esterno è esercitato dal Consiglio Comunale con l'aiuto della Corte dei Conti, che esprime un parere previo sul bilancio di governo che il Sindaco presenta ogni anno e lo sottopone al giudizio politico del Consiglio Comunale. Spetta alla Corte dei Conti il controllo tecnico dei conti, attraverso controlli contabili, finanziari, sui preventivi, sulle operazioni e sul patrimonio e il Consiglio Comunale ha il controllo politico di tali conti.

Parole chiave: separazione dei Poteri. Controllo. Obbligo del Sindaco di presentare il bilancio. Controllo esterno. Consiglio Comunale. Corte dei Conti. Controlli tecnici e politici. 


\section{SUMÁRIO}

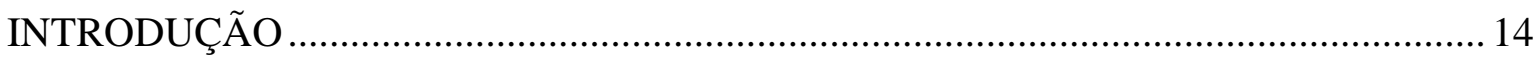

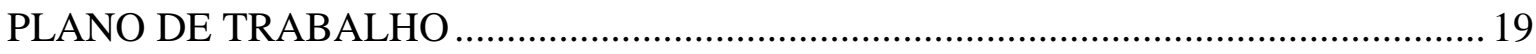

1. CAPÍTULO I: DO PODER DO ESTADO ….......................................................... 24

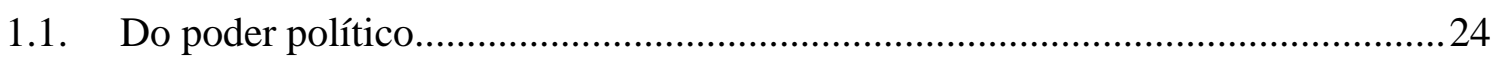

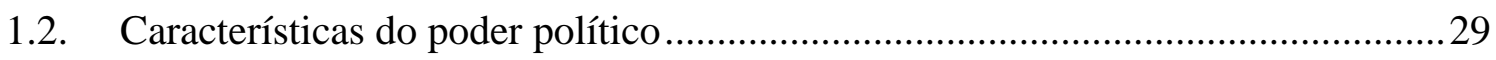

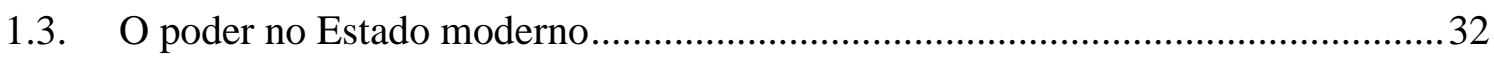

1.4. O princípio da separação de Poderes como fórmula de limitação e de controle do

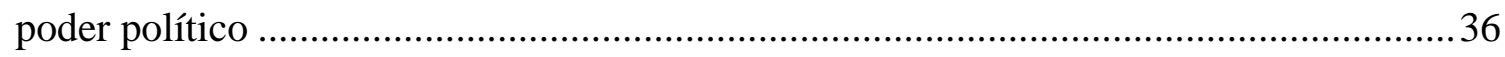

1.4.1. O Poder Legislativo: órgão de controle .................................................... 41

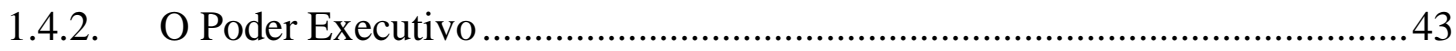

1.4.3. O Poder Judiciário: outro órgão de controle ..................................................46

1.4.3.1. O fenômeno da "judicialização da política" ............................................47

1.5. O princípio da separação de Poderes no século XX: novas perspectivas de divisão

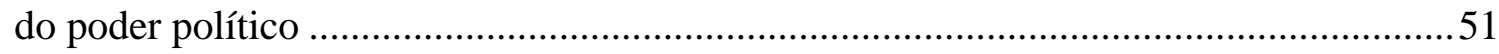

1.5.1. A função de controle inserida no processo do poder: a proposta de Karl

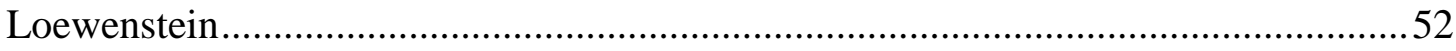

1.5.1.1. O Poder Legislativo e o controle político ...............................................55

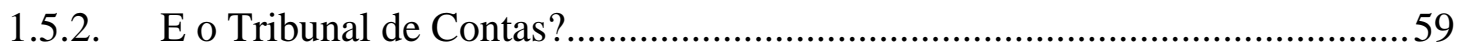

1.6. A responsabilidade do detentor do poder ....................................................... 61

1.6.1. A responsabilidade política.....................................................................63

2. CAPÍTULO II: O DEVER DE PRESTAR CONTAS E O CONTROLE DO PODER66

2.1. Evolução histórica do dever de prestar contas ...................................................68

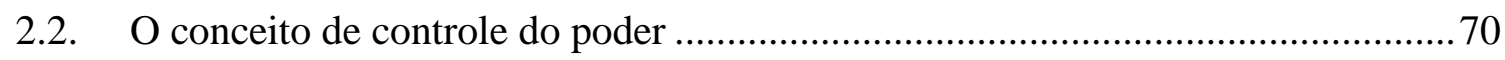

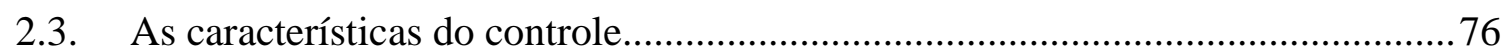

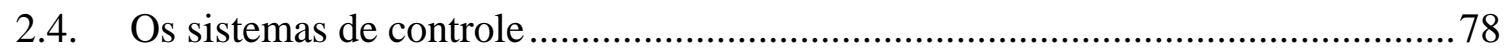

2.4.1. As "Entidades de Fiscalização Superiores" - (EFS) ou "Instituições Supremas de Controle - (ISC) das contas públicas .................................................. 78 
2.4.2. A independência das "Entidades de Fiscalização Superiores" - (EFS) ou

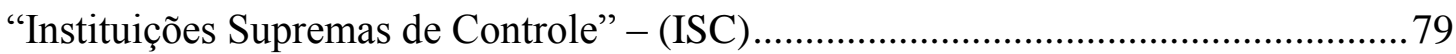

2.4.3. A Controladoria Geral, o Tribunal de Contas e o sistema misto ....................81

2.4.3.1. Características dos sistemas Controladoria Geral e Tribunal de Contas 83

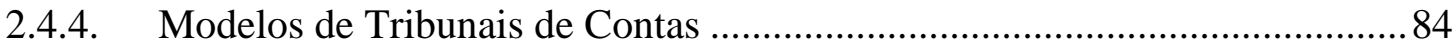

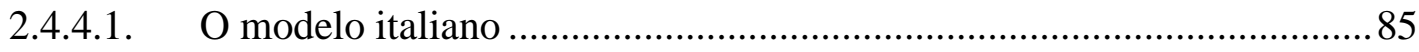

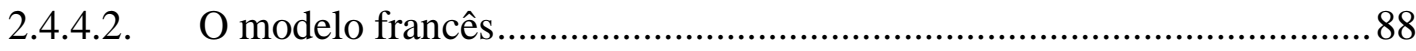

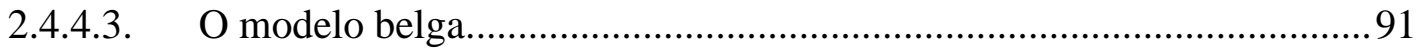

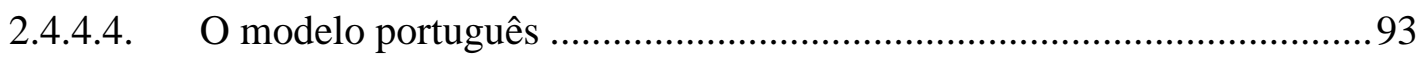

3. CAPÍTULO III: O CONTROLE DO PODER NO ORDENAMENTO BRASILEIRO.

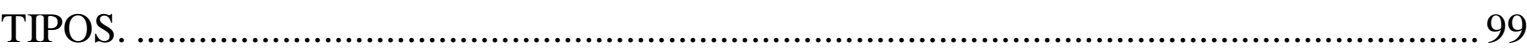

3.1. A "Entidade de Fiscalização Superior" brasileira: o Tribunal de Contas .............99

3.2. A independência e a autonomia do Tribunal de Contas brasileiro.......................101

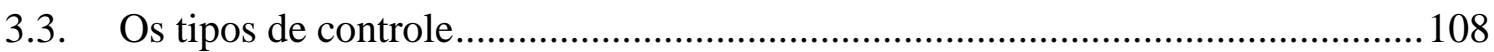

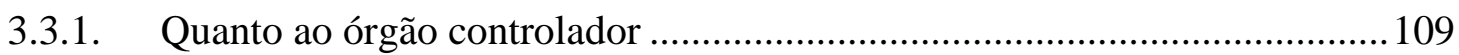

3.3.1.1. Controle administrativo (ou pelo Poder Executivo) ............................ 109

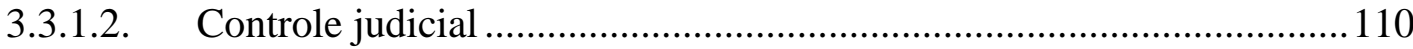

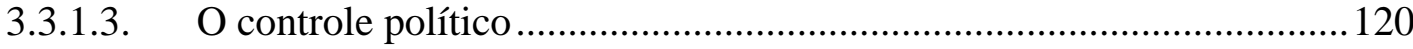

3.3.1.4. O controle realizado pelos órgãos constitucionais autônomos ..............120

3.3.1.4.1. O controle pelo Ministério Público ............................................................... 120

3.3.1.4.2. O controle pelo Tribunal de Contas ............................................................. 121

3.3.1.5. O controle popular (ou o controle social) ........................................ 123

3.3.2. Quanto ao momento em que o controle é realizado..................................128

3.3.2.1. Controle prévio, concomitante ou posterior ...................................... 128

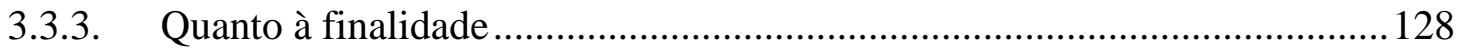

3.3.3.1. Controle de legalidade e de mérito .................................................... 128

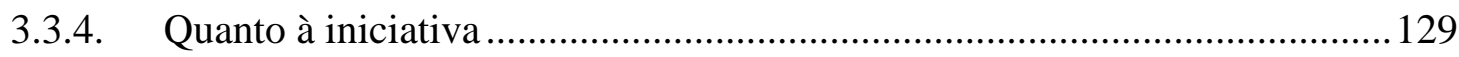

3.3.4.1. Controle de ofício e por provocação ................................................. 129 


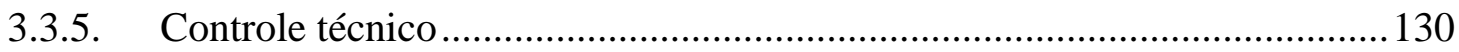

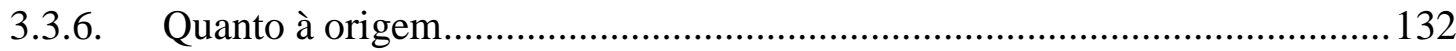

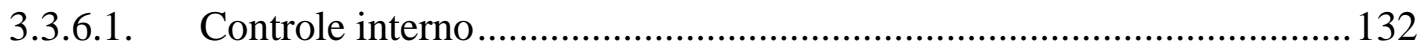

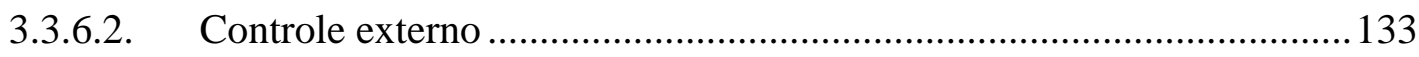

4. CAPÍTULO IV: O DEVER DE PRESTAR CONTAS E O CONTROLE EXTERNO DAS CONTAS MUNICIPAIS NA CONSTITUIÇÃO FEDERAL DE 1988 .................... 136

4.1. A prestação de contas na Constituição Federal Brasileira de 1988 ......................136

4.2. A prestação de contas pelo Prefeito ……………………………………….......137

4.3. Do Poder Legislativo municipal e suas funções ....................................................139

4.3.1. A preponderância da função de controle …………………………………...143

4.3.1.1. A função de controle financeiro …………………………………....... 145

4.3.1.2. A função de controle político ………………………………………....... 151

4.4. Do Tribunal de Contas em âmbito municipal …………………………………....159

4.4.1. O tratamento constitucional do Tribunal de Contas no âmbito do Município: os Tribunais de Contas dos Estados; os Tribunais (ou Conselhos) de Contas dos Municípios e os Tribunais de Contas dos Municípios de São Paulo e do Rio de Janeiro 160

4.4.2. A vedação constitucional para a criação de novos Tribunais, Conselhos ou

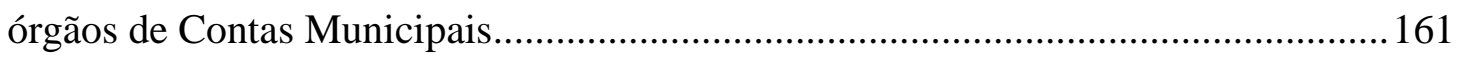

4.4.3. A ampliação da atividade fiscalizadora do Tribunal de Contas.....................162

4.4.4. As competências constitucionais e os tipos de contas ..................................167

4.4.4.1. A apreciação das "contas de governo" anualmente prestadas pelo Prefeito mediante a elaboração de um parecer prévio ...............................................169

4.4.4.2. O julgamento das "contas de gestão" dos administradores e responsáveis

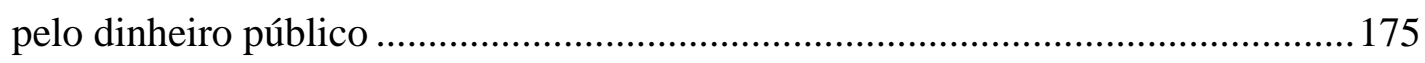

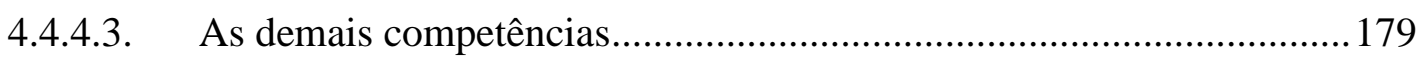

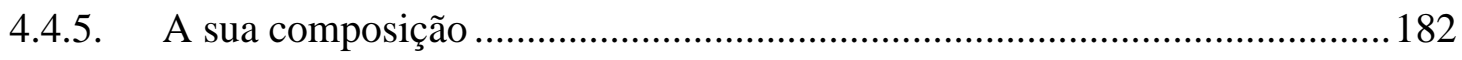

5. CAPÍTULO V: DA COMPETÊNCIA PARA A APROVAÇÃO DAS CONTAS

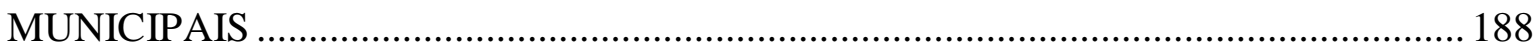


5.1. A participação do Tribunal de Contas na função fiscalizadora das "contas de governo" anualmente prestadas pelo Prefeito: a apreciação das contas municipais através da elaboração do parecer prévio

5.1.1. O significado de "parecer prévio"

5.1.2. Características do parecer prévio 191

5.1.2.1. O parecer prévio é técnico 191

5.1.2.2. O parecer prévio é obrigatório 194

5.1.2.3. O parecer prévio é meramente opinativo? 196

5.1.3. A imprescindibilidade da elaboração do parecer prévio do Tribunal de Contas para o julgamento anual das contas municipais pela Câmara Municipal.......206

5.2. A participação da Câmara Municipal na função fiscalizadora das "contas de governo" anualmente prestadas pelo Prefeito: o julgamento das contas municipais .....209

5.2.1. O julgamento político realizado pela Câmara Municipal 211

5.2.2. O critério constitucional para a rejeição do parecer prévio elaborado pelo Tribunal de Contas no âmbito do Município: a necessidade do voto de dois terços dos membros da Câmara Municipal. 216

5.3. A rejeição das contas de governo anuais dos Prefeitos do Município de São Paulo: os casos "Luíza Erundina" e "Celso Pitta"

5.3.1. A rejeição das contas de governo da Prefeita Luíza Erundina de Souza .....217

5.3.2. A rejeição das contas de governo do Prefeito Celso Roberto Pitta do Nascimento 219

5.4. Há controle político quando o Tribunal de Contas elabora o parecer prévio apreciando as contas de governo apresentadas pelo Prefeito? .222

5.5. A natureza da competência exercida pelo Tribunal de Contas e pela Câmara Municipal na aprovação das contas municipais .226

5.6. Os efeitos da atuação do Tribunal de Contas no âmbito municipal .232 


\section{INTRODUÇÃO}

O nosso trabalho visa a estudar " $O$ controle das contas municipais".

Sabe-se que o Estado absoluto é irresponsável. O Príncipe não responde pelos atos praticados no exercício do Poder. Não pode, pois, ser responsabilizado pelo mau uso do dinheiro público. A situação oposta ocorre no Estado Democrático de Direito: o governante, por representar o povo, responde pelos seus atos ao povo. Esta responsabilização faz-se nas urnas e, também na Casa do Povo, que é o Poder Legislativo. Daí porque necessário, no Estado de Direito, que o poder esteja repartido e devidamente limitado apresentando, como características essenciais, a existência de uma Constituição que contém as normas mais importantes e que deve ser respeitada, inclusive pelo mandatário do poder, e o princípio da separação de Poderes, tal como teorizado por Montesquieu.

Por este princípio, o poder político é dividido entre órgãos independentes e harmônicos, sendo-lhes atribuídas funções típicas. Ao Poder Legislativo é conferida a função de elaborar a lei, ao Executivo a função de administrar a lei e ao Judiciário a de dirimir os conflitos surgidos entre pessoas ou entre estas e o Estado. Esquece-se, no entanto, que o Poder Legislativo possui outras funções típicas, das quais o poder financeiro e o controle político são exemplos.

A função de poder financeiro nasceu em 1215 com a inserção do princípio do "no taxation without representation" na Magna Carta da Inglaterra. Este princípio vinculava a cobrança de tributos à existência de uma lei elaborada por representantes do povo. É a partir daí, então, que aparece a função legislativa, em que pese esta seja mais conhecida do que aquela. Mais tarde, a função de poder financeiro ganha outra conotação: a de controlar o uso e a destinação do dinheiro público utilizado pelo detentor do poder. Tem lugar, assim, a função de controle financeiro dos atos praticados pelo governo, isto é, passa o Poder Legislativo a controlar os gastos do Poder Executivo e o faz fiscalizando a matéria orçamentária. É o caso, por exemplo, da elaboração, pelo Poder Legislativo, da lei orçamentária aprovando o orçamento que será utilizado pelo 
Chefe do Poder Executivo para implantar as políticas públicas necessárias ao desenvolvimento do país.

Mais tarde, o controle financeiro adquire uma conotação investigatória, funcionando como verdadeiro "vigilante" dos atos praticados pelo Poder Executivo. Esta atividade investigatória é desempenhada com o auxílio de órgãos técnicos que têm como cerne melhor acompanhar a matéria orçamentária. Um destes órgãos é o Tribunal de Contas. Surge, assim, a função de controle externo que o Poder Legislativo realiza sobre a matéria orçamentária em relação ao Poder Executivo.

No cenário pátrio, a função de controle externo está inserida na Seção IX - "Da Fiscalização Contábil, Financeira e Orçamentária" -, do Capítulo I - "Do Poder Legislativo" -, do Título IV - "Da Organização dos Poderes". Estabelece a Constituição Federal de 1988, nos artigos 70, caput e 71, caput, que a fiscalização contábil, financeira, orçamentária, operacional e patrimonial das contas públicas será exercida pelo sistema de controle interno de cada Poder e pelo controle externo, este a cargo do Congresso Nacional, que o desempenha com o auxílio do Tribunal de Contas da União. Em razão do princípio da simetria constitucional e por disposição do artigo 75, caput, da Lei Maior, em âmbito municipal o controle externo das contas públicas é efetuado pela Câmara Municipal com o auxílio do Tribunal de Contas do Estado, do Tribunal (ou Conselho) de Contas dos Municípios do Estado da Bahia, do Ceará, de Goiás e do Pará ou, em se tratando de São Paulo e do Rio de Janeiro, pelos Tribunais de Contas do Município de São Paulo e do Município do Rio de Janeiro, respectivamente.

Já a função típica de controle político, que confere ao Poder Legislativo novamente destaque no cenário mundial, a partir da década de noventa, se desenvolve com o sistema de controles recíprocos mencionado por Montesquieu, e estabelece que o Poder Legislativo deve ser o fiscal dos atos praticados pelo Poder Executivo. Especificamente na matéria orçamentária, isto significa que o Poder Legislativo tem a competência exclusiva de "fiscalizar e controlar, diretamente, ou por qualquer de suas Casas, os atos do Poder Executivo, incluídos os da administração indireta" (artigo 49, X, da Constituição Federal de 1988), bem como a competência para julgar anualmente as contas prestadas pelo Chefe do Executivo (artigo 49, IX, da Constituição Federal). 
Ocorre que, no Estado Democrático de Direito pátrio, em esfera municipal, o julgamento das contas, que se caracteriza como um julgamento político, é precedido do dever que tem o Prefeito de prestar suas contas. Tal tarefa não se faz diretamente à Câmara Municipal e sim a um órgão intermediário: o Tribunal de Contas.

Verifica-se, assim, o funcionamento do sistema dos controles recíprocos, na medida em que a Câmara dos Vereadores tem a missão constitucional de fiscalizar como o dinheiro público é utilizado e de exigir, de seu responsável, a devida prestação das contas, sobre as quais responderá em caso de excessos praticados. Sendo responsável o Prefeito, à Câmara Municipal compete, ainda, o dever de julgar as contas, anualmente, demonstrando, com isso, que um Poder controla o outro, para que abusos não sejam cometidos.

Isto significa que a prestação de contas pelo Prefeito é uma das balizas mestras do Estado Democrático de direito. E por qual razão? É que, como o dinheiro público pertence ao povo, é ao povo que o Prefeito estará prestando contas quando a Câmara Municipal, que congrega os seus representantes, as julga. Ao Poder Legislativo municipal compete, pois, o julgamento político das contas.

Não obstante, antes do julgamento político pela Câmara Municipal, as contas passam por um controle técnico, que é desempenhado pelo Tribunal de Contas. A este competem as fiscalizações contábil, financeira, orçamentária, operacional e patrimonial das contas públicas. E, para bem exercer esta função técnica, o Tribunal deve ser independente e autônomo.

O Tribunal de Contas é, pois, órgão centenário no ordenamento pátrio. Existe desde o Governo Provisório, tendo sido implantado através do Decreto $\mathrm{n}^{\mathrm{o}}$ 966-A, da lavra de Ruy Barbosa. Foi criado para tornar o orçamento uma instituição independente e visava com isso combater a corrupção. Nos dias de hoje verifica-se a atualidade do tema: a corrupção e o deficit orçamentários continuam a ser objeto de preocupação na sociedade moderna, razão pela qual a função precípua do Tribunal de Contas na fiscalização das contas constitui papel de relevo no Estado Democrático de direito brasileiro.

Assim é que ao Tribunal de Contas foram conferidas atribuições importantes no controle técnico das contas municipais: a ele compete a apreciação das 
contas de governo prestadas pelo Prefeito, através da elaboração de um parecer prévio técnico e obrigatório - para o posterior julgamento político das contas municipais a ser efetuado pela Câmara Municipal, cabendo-lhe, ainda, o julgamento das contas dos demais gestores públicos, tudo em consonância com os incisos I e II do artigo 71 da Constituição Federal de 1988.

No que tange especificamente às contas de governo em âmbito municipal, devem elas ser apresentadas pelo Prefeito, anualmente, após sessenta dias da abertura da sessão legislativa, cabendo ao Tribunal de Contas a elaboração do parecer prévio, no Município de São Paulo, no prazo de noventa dias após o seu recebimento. Elaborado o parecer prévio - opinando pela aprovação ou pela rejeição das contas municipais - é ele encaminhado para o julgamento político da Câmara Municipal.

Questão interessante que ocorre apenas em seara municipal diz respeito à rejeição do parecer prévio elaborado pelo Tribunal de Contas. É que, por disposição constitucional, contida no $\S 2^{\circ}$ do artigo 31 , são necessários dois terços dos votos dos membros da Câmara Municipal para derrubar o referido parecer prévio, que opinou pela aprovação ou pela rejeição das contas de governo prestadas pelo Prefeito. O tema sugere várias indagações. E qual o motivo, em âmbito municipal, de exigir-se maioria qualificada de dois terços - que é superior à maioria qualificada de três quintos existente para a aprovação de emendas constitucionais - para derrubar o parecer prévio elaborado pela Corte de Contas? Pode-se dizer, então, como defende parte da doutrina, que a natureza do parecer prévio ao apreciar as contas de governo prestadas pelo Prefeito é meramente opinativa? É o parecer prévio capaz de - sozinho - gerar a inelegibilidade do Prefeito que teve as suas contas rejeitadas pelo Tribunal de Contas (órgão que realiza o controle técnico) ou a inelegibilidade do Chefe do Executivo municipal só se concretiza com o julgamento político efetuado pela Câmara Municipal? Qual órgão é capaz de causar a responsabilidade política do mau gestor público?

Para responder a estas questões, tratamos de estudar, especificamente, em que consistem as competências da Câmara dos Vereadores e do Tribunal de Contas na aprovação das contas municipais, isto é, estudamos pormenorizadamente as competências relativas à apreciação das contas desempenhada pelo Tribunal de Contas e a referente ao seu julgamento político na Câmara Municipal. 
Nosso estudo, ainda, tem como cerne responder às grandes questões que se inserem como a "novidade" trazida pela tese: o Tribunal de Contas também exerce controle político quando elabora o parecer prévio das contas de governo anualmente prestadas pelo Prefeito ou esta competência é exclusiva da Câmara Municipal? E mais, qual a natureza da competência exercida pelo Tribunal de Contas e pela Câmara Municipal na aprovação das contas municipais? É mesmo de mero "auxílio", querendo este significar dependência do Poder Legislativo municipal ou há entre ambos - Tribunal de Contas e Câmara Municipal - verdadeira cooperação na aprovação das contas?

Objetivamos, pois, com o estudo proposto, demonstrar a real importância da função fiscalizadora relativa ao controle financeiro sobre as contas municipais, realizada pela Câmara dos Vereadores e pelo Tribunal de Contas, ambos no exercício do controle externo. 


\section{PLANO DE TRABALHO}

Para estudar o tema proposto - O controle das contas municipais dividimos o trabalho em cinco capítulos.

O Capítulo I - intitulado Do poder do Estado - parte do estudo do poder social, que é o existente em uma sociedade, para, depois, examinar, especificamente, o poder político. Tratamos de diferenciar o poder político das outras espécies de poder, trazendo as características do primeiro. Em seguida, analisamos a estrutura do poder político nos Estados modernos, pois foi a partir das grandes revoluções, que culminaram com o nascimento dos Estados modernos, que esse poder político passou a ser limitado, fazendo surgir o Estado de Direito, que apresenta, como um de seus pilares, o princípio da separação de Poderes. Apresentamos, assim, as características do princípio na visão clássica de Montesquieu. Em seguida, cuidamos de cada um dos órgãos do Estado Legislativo, Executivo e Judiciário - ganhando destaque a análise da função de controle concernente ao Poder Legislativo, sobre a qual voltaremos a discorrer no Capítulo IV, itens 4.3.1.1 (A função de controle financeiro) e 4.3.1.2 (A função de controle político).

Ainda no que concerne à separação de Poderes, investigamos a proposta de Karl Loewenstein, que nos oferece uma nova abordagem sobre a teoria de Montesquieu. O autor insere a função de controle no processo do poder político, conferindo a função de controle político ao Parlamento. O Parlamento controla, assim, os atos praticados pelo governo, fazendo surgir o princípio da responsabilidade política. É possível, pois, exigir a responsabilidade política do mau detentor, ou, no nosso caso, do detentor que usou mal os recursos públicos e que não prestou contas devidamente aos outros detentores do poder.

Em sequência, tratamos de lançar as linhas gerais da atuação do Tribunal de Contas, uma vez que, em que pese tratar-se de um órgão de controle, não foi ele inserido no processo do poder político traçado por Montesquieu e por Karl Loewenstein.

Por último, neste Capítulo, examinamos o instituto da responsabilidade do poder. Isto porque, em um Estado de Direito, em que o poder é 
limitado, torna-se imprescindível a identificação da conduta do agente político, fazendo-o responder à sociedade pelos atos praticados, uma vez que ele nada mais é do que representante do povo. Assim, todas as vezes que o representante não atua de acordo com a vontade dos governados (representados) que o elegeram, cometendo abusos ou praticando ilegalidades, deve ele ser responsabilizado politicamente. A responsabilidade funciona, pois, como uma forma de limitar o poder político e está relacionada com o dever de prestar contas. No nosso trabalho, incide a responsabilidade política quando a prestação de contas ao povo não for realizada ou for feita de modo insatisfatório, vale dizer, quando os recursos públicos não forem bem aplicados pelo gestor.

O Capítulo II - O dever de prestar contas e o controle do poder se inicia com o estudo do dever que o gestor público - Prefeito ou outro administrador público - tem de prestar contas. Isto porque este instituto - a prestação de contas - é imprescindível em um Estado Democrático de Direito e é por meio dele que o povo controla o poder político. Assim é que só se pode falar em prestação de contas pelo Prefeito - que é o objeto de nosso interesse - em um Estado em que o poder político esteja limitado e controlado. É por isso que trazemos, na sequência, o conceito de controle do poder. Abordamos as diversas acepções da palavra "controle", para concluir que, em nosso trabalho, o vocábulo significa "vigilância" (ou "fiscalização") ou, ainda, "verificação".

Apresentamos, em seguida, as características do controle e os seus sistemas, com destaque para as "Entidades de Fiscalização Superiores" (EFS) ou "Instituições Supremas de Controle" (ISC), órgãos técnicos e independentes, cuja especialidade é fiscalizar - sob o aspecto técnico - as contas públicas em nome do povo e que existem em diversos países do mundo. Exemplo destas "Entidades de Fiscalização Superiores”, em cenário pátrio, é o Tribunal de Contas, que objetiva cooperar com o Poder Legislativo na realização do controle externo das contas do Executivo. Abordamos, ainda, o sistema de Tribunal de Contas na Itália, França, Bélgica e em Portugal, este último em razão das similitudes na elaboração do parecer a ser aprovado ou rejeitado pelo Poder Legislativo, em que pese, em Portugal, esteja a Corte de Contas inserida no Poder Judiciário.

O Capítulo III - O controle do poder no ordenamento brasileiro. Tipos. - se inicia com a análise da "Entidade de Fiscalização Superior" brasileira, que é o Tribunal de Contas. Explicamos que ele é um órgão constitucional autônomo e 
independente, para bem exercer o seu mister constitucional. Posteriormente, passamos ao exame dos diversos tipos de controle, que pode ser administrativo, judicial, político, realizado pelo Ministério Público ou pelo Tribunal de Contas ou popular; prévio, concomitante ou posterior; de legalidade ou de mérito; de ofício ou por provocação; técnico e; interno ou externo.

Já o Capítulo IV - O dever de prestar contas e o controle externo das contas municipais na Constituição Federal de 1988 - aborda a prestação de contas no cenário municipal pátrio. O Capítulo é fundamentado em três pilares: a prestação de contas pelo Prefeito, a função de controle externo das contas municipais a cargo do Poder Legislativo e as atribuições do Tribunal de Contas nesta mesma função de controle externo.

Começamos, pois, por verificar a obrigação de o Prefeito, que utiliza o dinheiro público, prestar contas anualmente do uso que conferiu a estes recursos. Em seguida, explicamos como atua a Câmara dos Vereadores na função de controle externo, cuidando, especificamente, das funções de controle financeiro e de controle político, definindo cada uma delas, para concluir que o julgamento das contas anualmente prestadas pelo Prefeito se caracteriza como controle político. As contas são, porém, apresentadas a um órgão intermediário, que é o Tribunal de Contas, ao qual compete o seu controle técnico.

Partimos, assim, para a análise da atuação do Tribunal de Contas no exame das contas de governo prestadas pelo Prefeito. Explicamos como se dá o tratamento constitucional do Tribunal de Contas no âmbito do Município; que é vedada a criação de novos Tribunais de Contas em âmbito municipal; quais foram as ampliações às competências da Corte de Contas trazidas pela Constituição Federal de 1988; qual a composição do órgão e quais são as suas competências, sendo, as mais importantes, as referidas nos incisos I e II do artigo 71 da Constituição Federal, que estabelecem, primeiramente, que ao Tribunal de Contas compete a apreciação das contas de governo prestadas pelo Prefeito, através da elaboração de um parecer prévio que é julgado pela Câmara Municipal e, no segundo caso, confere ao Tribunal o julgamento das contas dos demais gestores públicos. 
Tratamos, neste tópico, ainda, de explicar por qual razão, em nosso entendimento, o parecer prévio que rejeita as contas do Prefeito não é capaz de, sozinho, causar a inelegibilidade do Prefeito, prevista na alínea "g" do inciso I do artigo $1^{\circ}$ da Lei Complementar $n^{\circ}$ 64/90 com redação dada pela Lei Complementar $n^{\circ} 135 / 10$, conhecida como a Lei da "Ficha Limpa", resultado que se apresenta diferente quando os demais gestores públicos são julgados pelo Tribunal de Contas, já que, nestes casos, o administrador público torna-se inelegível, incidindo na previsão inserta na alínea, inciso e artigo da Lei anteriormente citada.

O Capítulo V - Da competência para a aprovação das contas municipais -, por seu turno, analisa, especificamente, o inciso I do artigo 71 da Constituição Federal, com incidência no âmbito municipal em razão do princípio da simetria constitucional, e que se refere à participação do Tribunal de Contas e da Câmara Municipal na função fiscalizadora das contas de governo anualmente prestadas pelo Prefeito. Ao primeiro, compete a elaboração do parecer prévio, motivo pelo qual apresentamos as suas características, e à segunda, o julgamento político. Tratamos de diferenciar o controle técnico realizado pelo primeiro do controle político a cargo da segunda para, nas "novidades" trazidas pela tese, examinar, com atenção: 1) se o Tribunal de Contas também exerce controle político quando aprecia as contas do Prefeito através da elaboração de um parecer prévio e 2) qual a natureza da competência exercida pelo Tribunal de Contas e pela Câmara Municipal na aprovação das contas municipais.

O Capítulo termina com o exame dos efeitos da atuação do Tribunal de Contas em cenário municipal, no qual abordamos a importância da atuação do Tribunal de Contas para o controle das contas municipais.

Ademais, para melhor ilustrar a importância do parecer prévio em âmbito municipal, trazemos à colação os motivos que levaram a Corte de Contas paulista a rejeitar os pareceres prévios das contas de governo dos ex-Prefeitos Luíza Erundina (1991) e Celso Roberto Pitta do Nascimento (1999 e 2000) para, a seguir, apontar a atuação da Câmara Municipal, que manteve os pareceres prévios citados, pela rejeição das contas de governo prestadas pelos Prefeitos. Analisamos, ainda, a conduta dos ex-Prefeitos que, inconformados, recorreram ao Poder Judiciário para reverter as decisões - não da Corte de Contas mas sim da Câmara dos Vereadores - e as consequências da decisão judicial para o julgamento político realizado pelo Poder Legislativo municipal. 
Todo o trabalho é, ainda, complementado por vasta pesquisa jurisprudencial, aduzindo como os Tribunais Superiores se comportam na matéria relativa ao controle externo das contas municipais. 


\section{CAPÍTULO I: DO PODER DO ESTADO}

\subsection{Do poder político}

A palavra "poder" possui diversos significados. O dicionário Melhoramentos da Língua Portuguesa, por exemplo, traz onze ${ }^{1}$ conceituações diferentes para este vocábulo, ora associando-o a uma mera faculdade ("faculdade, possibilidade"); ora a uma autoridade ("faculdade de impor obediência; autoridade, mando"); à força ("força ou influência; força fisica ou moral) e, até mesmo, ao Estado (poder aqui entendido como o "governo de um Estado"). Quanto a este último, muitas vezes a expressão "poder político" é utilizada como sinônimo de poder, "significando autoridade, por meio de prerrogativas legais e políticas". 2

Pode-se falar, também, em poder econômico, poder paterno/materno, poder de fato, poder de direito, por exemplo. É possível, ainda, relacionálo à Igreja (poder espiritual) ou ao Estado.

Importa, para este trabalho, estudarmos o poder social, isto é, aquele existente em uma sociedade e, nesta, especificamente, o poder político.

Assim é que, enquanto fenômeno social, isto é, considerando o poder em uma sociedade organizada, Mario Stoppino, na seara da política, aduz que "o poder é necessário e se converte, de genérica capacidade de agir, na capacidade do homem para determinar a conduta do homem: o poder do homem sobre o homem". 3

\footnotetext{
${ }^{1}$ De acordo com o Dicionário Melhoramentos da Língua Portuguesa, "poder" é conceituado como: "1. Faculdade, possibilidade. 2. Faculdade de impor obediência; autoridade, mando. 3. Império, soberania. 4. Posse, jurisdição, domínio, atribuição. 5. Governo de um Estado. 6. Forças militares. 7.Força ou influência. 8. Força física ou moral. 9. Eficácia, efeito, virtude. 10. Meios, recursos. 11. Capacidade de agir ou de produzir um efeito: P. aquisitivo -. P. espiritual: autoridade eclesiástica. P. temporal: a) autoridade civil; b) o poder dos papas como soberanos espirituais". Dicionário Melhoramentos da Língua Portuguesa. Antônio Houaiss (apresentação). São Paulo: Melhoramentos, 1994. p. 803.

${ }^{2}$ MORAES, Filomeno. Verbete Poder. In: BARRETTO, Vicente de Paulo. (Coord.). Dicionário de Filosofia do Direito. São Leopoldo: Unisinos e Rio de Janeiro: Renovar, 2006. p. 640.

${ }^{3}$ No original: “(...) el p. se precisa y se convierte, de genérica capacidad de obrar, em capacidad del hombre para determinar la conducta del hombre: p. del hombre sobre el hombre". STOPPINO, Mario. Verbete Poder. In: BOBBIO, Norberto; MATTEUCCI, Nicola (Coord.). Dicionário de Política L-Z. Gianfranco Pasquino (redator). Tradução de José Aricó e Jorge Tula. $2^{\mathrm{a}}$ ed. Madrid: Siglo Veintiuno de España Editores, 1983. p. 1.217.
} 
Este "poder do homem sobre o homem" apresenta-se, para Karl Loewenstein, ainda no campo da ciência política, como uma relação entre os detentores e os destinatários do poder. De acordo com o autor:

\begin{abstract}
"Considerada como um todo, a sociedade é um sistema de relações de poder, cujo caráter pode ser político, social, econômico, religioso, moral cultural ou de outro tipo. O poder é uma relação sociopsicológica baseada em um efeito recíproco entre os que detêm e exercem o poder - os detentores do poder - e aqueles a quem o poder é dirigido - os destinatários do poder". (tradução nossa)
\end{abstract}

Já no campo da filosofia do Direito, Filomeno Moraes define o poder como "a capacidade, atual e potencial, de impor-se a vontade sobre os outros, inclusive, mas não necessariamente, contra a sua resistência". 5

O que se extrai dos conceitos citados é que a relação entre os homens e o poder, em uma sociedade, resulta na existência de um dominante e de um dominado, cabendo ao primeiro impor a sua vontade sobre o segundo.

Analisado o conceito de poder dentro de uma sociedade, cumprenos, agora, trazer à colação um conceito para o poder político (ou poder estatal).

Monica Herman Salem Caggiano explica que o poder político deve, necessariamente, balizar a relação liberdade individual/bem-estar social ${ }^{6}$, que existe em toda a sociedade organizada. Nesse sentido, preleciona a autora que:

\footnotetext{
4 "Considerada como un todo, la sociedad es un sistema de relaciones del poder cuyo carácter puede ser político, social, económico, religioso, moral, cultural o de outro tipo. El poder es una relación sociopsicológica basada en un recíproco efecto entre los que detentan y ejercen el poder - séran denominados los detentadores del poder - y aquellos a los que va dirigido - séran aqui designados como los destinatarios del poder". LOEWENSTEIN, Karl. Teoría de la Constitución. Traducción y estudio sobre la obra por Alfredo Gallego Anabitarte. Barcelona: Editorial Ariel, 1976. p. 26. Também aqui, o autor explica que dentro de uma sociedade pode haver uma diversidade de poderes, como, por exemplo, o político, o econômico, o moral, etc.

${ }_{6}^{5}$ MORAES, Filomeno. Op. cit. p. 640.

${ }^{6}$ Acerca da relação liberdade individual/bem-estar social, relata Monica Herman Salem Caggiano: "reponta, a esse passo, o eterno paradoxo - liberdade individual/bem-estar social - questão que envolve exatamente o problema da conciliação entre a ordem social indispensável para que o homem viva em segurança e a liberdade, sem a qual sequer valeria a pena viver. Por isso é que, admitem os teóricos, em consenso quase que pacífico, discorrer acerca da liberdade, ou simplesmente proclamá-la não implica maiores problemas, porquanto o que na realidade importa é posicioná-la numa conjuntura social, situá-la e definir-lhe os contornos no quadro de uma ordem social viável". CAGGIANO, Monica Herman Salem. Oposição na política: propostas para uma rearquitetura da democracia. São Paulo: Angelotti, 1995. pp. 25-26.
} 
"A questão que avulta, pois, é a forma de organização do poder, dessa esfera de relacionamento que encerra fenômenos de interação e de interdependência, com vistas a resguardar a liberdade, até porque o exercício do poder e os reflexos que esse irradia são distintos, dependendo exatamente do arranjo adotado e da ideologia que lhe serve de pauta".

$\mathrm{Ou}$ seja, proteção da liberdade individual e poder político se relacionam em uma sociedade organizada.

Karl Loewenstein, por sua vez, aduz:

"Em uma sociedade estatal, o poder político aparece como o exercício de um efetivo controle social dos detentores sobre os destinatários do poder". ${ }^{8}$ (grifos nossos)

Explica, ainda, o mesmo autor, que:

"Por controle social, no estrito sentido da ciência política contemporânea, se deve entender a função de tomar ou determinar uma decisão, assim como a capacidade dos detentores do poder de obrigar os destinatários do poder a obedecer tal decisão". ${ }^{9}$

Norberto Bobbio, no mesmo sentido que Karl Loewenstein, assevera que o poder político é compreendido como “'poder coercitivo' e 'exclusivo', ou seja, detentor do monopólio do uso da força (ou dos meios de coação)". ${ }^{10}$

O poder político, portanto, é exclusivo ${ }^{11}$ e está associado ao poder coercitivo, capaz de obrigar os destinatários deste poder.

\footnotetext{
${ }^{7}$ Idem. p. 26.

8 "En la sociedad estatal, el poder político aparece como el ejercicio de un efectivo control social de los detentadores del poder sobre los destinatarios del poder". LOEWENSTEIN, Karl. Op. cit. p. 27.

9 "Por control social, en el estricto sentido de la ciencia política contemporánea, se debe entender la función de tomar o determinar una decisión, así como la capacidad de los detentadores del poder de obligar a los destinatarios del poder a obedecer dicha decisión". Idem. Ibidem.

${ }^{10}$ BOBBIO, Norberto. Teoria geral da política: a filosofia política e as lições dos clássicos. BOVERO, Michelangelo (Org.). Tradução de Daniela Beccaccia Versiani. $6^{\text {a }}$ Tiragem. Rio de Janeiro: Campus, 2000. p. 34.

${ }^{11}$ Rodrigo Borja diferencia o poder do Estado do poder das outras "sociedades menores existentes dentro do Estado", como ele as chama. Explica que o poder do Estado "está dotado de uma força dominante, irresistível, que tem o monopólio da coação física legítima. Exercer este poder é mandar de uma maneira absoluta e estar em situação de coagir para a execução das ordens dadas. Em troca, o poder das sociedades especiais é restrito, está limitado ao campo de suas atividades específicas e sua eficácia está condicionada à permissão do poder estatal”. BORJA, Rodrigo. Derecho político y constitucional. $2^{\mathrm{a}}$ ed. Primera reimpresión.
} 
Como, no entanto, a imposição aos destinatários se concretiza?

Tanto pode ela decorrer da vontade de uma pessoa - o rei ${ }^{12}$ - que personifica o poder soberano, além de possuir o poder de mando, como também, derivar do fenômeno da institucionalização do poder $^{13}$ que consiste, segundo Manoel Gonçalves Ferreira Filho, em o poder "ser separado dos indivíduos que o exercem, segundo regras preestabelecidas que o atribuem a um titular abstrato" "14, sendo, esse titular abstrato, o Estado $^{15}$.

Sobre a relação entre Estado e poder político, preleciona Rodrigo

Borja:

\begin{abstract}
“(...) o Estado necessita de uma vontade dominante e investida de autoridade para dirigir a atividade social e coordenar os esforços individuais. Esta vontade dominante e investida de autoridade, capaz de se fazer obedecer compulsivamente se chama poder político ou poder público". ${ }^{16}$ (grifos e tradução nossos)
\end{abstract}

No mesmo sentido do autor precitado, José Afonso da Silva

prescreve:

México: Fondo de Cultura Económica, 1992. pp. 60-61. ("Pero es indudable que el poder del Estado, a diferencia de los que existen en las agrupaciones subalternas, está dotado de uma fuerza dominante, irresistible, que tiene el monopolio de la coacción física legítima. Ejercer esse poder es mandar de uma manera absoluta y estar en situación de coaccionar la ejecución de las ordenes dadas. En cambio, el poder de las sociedades especiales es restringido, está limitado al campo de sus actividades específicas y su eficácia está condicionada a la permisión del poder estatal".)

${ }^{12}$ Lembre-se que no Absolutismo valia a regra: "O Estado sou eu", já que o rei personificava o poder.

${ }^{13}$ Tratando da institucionalização do poder, Luis Sanchez Agesta explica: "En la medida en que se reconoce um 'derecho a mandar', se acepta un fundamento de esse derecho. La persona 'autorizada' para ejercerlo está trascendida por el mismo fundamento de su autoridad. El poder de autoridad supone la imputación subjetiva del poder como un derecho; el vínculo de obediencia se apoya em último término en los hechos o en los principios en que esse derecho se funda. Se obedece a una persona, pero no por sí misma, sono por la función que cumple, la legalidad de su posición jurídica, la tradición que em ella se concreta o la representación que se le atribuye. En todo caso, por su inserción en un orden que se considera justo o, al menos, legítimo. Esta es una de las vías por las que el poder se institucionaliza. El poder, emanado de la estructura social, se inserta así en la organización política como un elemento estable". (grifos nossos) AGESTA, Luis Sanchez. Princípios de teoria política. $2^{\mathrm{a}}$ impresión. Madrid: Editora Nacional, 1967. p. 344.

${ }^{14}$ FERREIRA FILHO, Manoel Gonçalves. O poder e seu controle. Revista de Informação Legislativa. Ano 21, n. 84. Brasília: out./dez., 1984. p. 78.

${ }^{15}$ Acerca da institucionalização do poder através da sua entrega ao Estado (o "titular abstrato"), explica Manoel Gonçalves Ferreira Filho, que ela (a institucionalização do poder) se concretiza “(...) ao se consolidar a idéia de que o poder não é apanágio de um indivíduo como tal, mas tem um suporte que transcende aos que o exercem. Um suporte impessoal, em geral simbolizado, estruturado em normas obrigatórias". FERREIRA FILHO, Manoel Gonçalves. O poder e seu controle. Revista de Informação Legislativa. Ano 21, n. 84. Brasília: out./dez., 1984. p. 79.

16 “(...) el Estado necesita una voluntad dominante e investida de autoridad para dirigir la actividad social y coordinar los esfuerzos individuales. Esa voluntad dominante e investida de autoridad, capaz de hacerse obedecer compulsivamente, se llama poder político o poder público”. BORJA, Rodrigo. Op. cit., p. 58. 
"O Estado, como grupo social máximo e total, tem também o seu poder, que é o poder político ou poder estatal. A sociedade estatal, chamada também sociedade civil, compreende uma multiplicidade de grupos sociais diferenciados e indivíduos, aos quais o poder político tem que coordenar e impor regras e limites em função dos fins globais que ao Estado cumpre realizar. Daí se vê que o poder político é superior a todos os outros poderes sociais, os quais reconhece, rege e domina, visando a ordenar as relações entre esses grupos e os indivíduos entre si reciprocamente, de maneira a manter um mínimo de ordem e estimular um máximo de progresso à vista do bem comum". ${ }^{17}$ (grifos nossos)

A "superioridade" do poder político justifica-se no fato de a ele competir a concretização dos "interesses gerais da sociedade" ou do "bem comum". Apresenta-se, assim, com uma característica que o distingue de todas as outras formas de poder anteriormente citadas. Mas, de que forma tal superioridade é mantida?

Consoante Paulo Bonavides, pela força e pela competência. Explana o autor que o poder é um elemento essencial do Estado e que com ele (o poder) "se entrelaçam a força e a competência, compreendida esta última como a legitimidade oriunda do consentimento". ${ }^{18}$

O mencionado autor repudia o poder estatal baseado exclusivamente no uso da força, pois, neste caso, o cumprimento das normas e das leis pela sociedade fica condicionado, exclusivamente, à violência e, dessa forma, o poder não se legitima, fazendo nascer, então, apenas um poder de fato. O poder de direito, ao contrário, decorre da conexão entre a força e a competência, o que demonstra o aval, o consentimento (a legitimação) da população quanto ao seu exercício.

Para Filomeno Moraes, a resposta não está apenas no uso da força, mas também no da persuasão ${ }^{19}$, entendida esta como o mecanismo mais seguro do exercício do poder, "pois faz com que o dominado aceite a dominação como justa ou razoável".20

Manoel Gonçalves Ferreira Filho perfilha o entendimento de Filomeno Moraes. Explica que o uso da força é o que diferencia o poder político das

17 SILVA, José Afonso da. Curso de direito constitucional positivo. $25^{\mathrm{a}}$ ed. rev. e atual. São Paulo: Malheiros, 2005. p. 107.

${ }^{18}$ BONAVIDES, Paulo. Ciência política. $10^{\mathrm{a}}$ ed. rev. e atual. São Paulo: Malheiros, 2000. p. 106.

${ }^{19}$ Por isso Filomeno Moraes diz “... mas não, necessariamente, contra a sua resistência”. (Vide nota 5, no corpo do texto).

${ }^{20}$ MORAES, Filomeno. Op. cit. p. 641. 
demais formas de poder. Aduz, no entanto, que a superioridade do poder político não se mantém unicamente pela força e sim pela ideia de direito ${ }^{21}$, entendida esta como a crença do povo acerca do que é certo, do que é justo em sua comunidade. Isto é, os indivíduos obedecem às normas provenientes do Estado porque acreditam que suas determinações são devidas, são justas.

Apresentados o poder e o poder político, passamos, em seguida, à análise das características deste último.

\subsection{Características do poder político}

Como se viu no tópico anterior, diversas são as acepções para o vocábulo "poder". Interessa, para o nosso trabalho, o poder político que é institucionalizado, ou seja, separado dos indivíduos em geral e atribuído a um ente despersonalizado, o Estado, que, por ser detentor do monopólio da força, impõe o cumprimento das normas para toda a coletividade, estabelecendo, assim, uma relação dominante-dominado ou detentor-destinatário do poder. O fundamento da superioridade do poder não se encontra, no entanto, apenas na coerção e sim também na "competência", "persuasão" ou "ideia de direito", dependendo do autor que se consulte, expressões que, na verdade, convergem para a crença de que as pessoas cumprem as normas, primeiramente, porque acreditam que elas são justas, são corretas para aquela coletividade em determinado momento e, depois, porque se não o fizerem, poderão ser apenadas através da força estatal.

Destacado o poder político, abordamos, em seguida, a análise de suas características, que são, para este trabalho, trazidas por Paulo Bonavides ${ }^{22}$.

A primeira delas diz respeito à imperatividade $e$ à natureza integrativa do poder estatal e concerne ao fato de que o convívio social é necessário, não

\footnotetext{
${ }^{21}$ Manoel Gonçalves Ferreira Filho assevera que o poder está sempre fundamentado em uma crença, que é o que lhe garante superioridade. Esta crença é representada pela "idéia de direito". Nas palavras do autor: "O poder institucionalizado deve ser mais forte do que os poderes sociais, ao menos isolados, para que se possa impor sobre eles. Tem de ser, numa palavra, incontrastável. Entretanto, nunca se pode olvidar que essa superioridade se arrima numa idéia de direito que consagra a prevalência do interesse geral (ou ao menos do que assim se apresenta) sobre os interesses particulares”. FERREIRA FILHO, Manoel Gonçalves. O poder... Op. cit. p. 81.

${ }^{22}$ Para maiores detalhes, vide: BONAVIDES, Paulo. Op. cit. pp. 107-110
} 
havendo possibilidade de o homem viver fora da sociedade. Cabe, ainda, ao Estado, em último caso, de maneira exclusiva, o emprego da força para obrigar ${ }^{23}$ tal associação.

Ademais, sendo o Estado uma pessoa jurídica, o poder político é atribuído a uma minoria (o governo ou o detentor do poder) que impõe à maioria (os governados ou destinatários do poder), o cumprimento das normas, sob pena de utilização do monopólio da força, que é exclusivo do Estado, como anteriormente afirmado.

A segunda característica consiste na capacidade de autoorganização do Estado, competindo-lhe, então, a elaboração de seu próprio direito, de sua própria organização constitucional. Entende-se que o poder estatal, para que possa imporse à coletividade, deve estar baseado em uma ordem constitucional criada por ele, daí falar-se em Estado de Direito ${ }^{24}$, característico da Idade Moderna.

Citamos, na sequência, a unidade e a indivisibilidade do poder, significando que o titular ${ }^{25}$ do poder é um só: o Estado como pessoa jurídica ${ }^{26}$, que se manifesta pelas figuras do monarca, de uma classe ou do povo.

Esta é uma típica característica do Estado moderno, onde o poder do Estado foi desvinculado do seu detentor, fazendo surgir a diferenciação entre o titular e aquele que exerce o poder. O titular é um só e, no Estado Democrático de Direito materializa-se no povo, cabendo o exercício do poder aos representantes deste (que é o seu titular). É possível falar, assim, em separação do exercício das funções do Estado - as conhecidas funções legislativa, executiva e judiciária, provenientes da separação de Poderes -, em contraposição à concentração das funções em uma só pessoa, marca do Estado absoluto.

Segundo Paulo Bonavides, outro traço característico do poder é a soberania, o maior poder do Estado, entendida como uma qualidade do poder. No âmbito

\footnotetext{
${ }^{23}$ Nas outras formas de associações, o ingresso e a saída das pessoas são voluntários, de modo que não se pode falar em imperatividade do poder. É que nestes casos não há uma força superior obrigando as pessoas a se manterem na sociedade e, dessa forma, a entrada e a retirada do indivíduo são livres.

${ }^{24}$ É que foi com o Estado de Direito que o Estado submeteu-se à ordem constitucional e, pois, às normas por ele mesmo criadas, fenômeno não observado no Estado absoluto, onde o rei se encontrava acima da lei.

${ }^{25}$ Paulo Bonavides explica o conceito de "titular do poder": "Titulares do poder são aquelas pessoas cuja vontade se toma como vontade estatal”. BONAVIDES, Paulo. Op. cit. p. 109. No Estado Democrático de Direito, dita vontade pertence ao povo.

${ }^{26}$ Sobre o tema, profere Paulo Bonavides: "A indivisibilidade do poder configura uma outra nota característica do poder estatal. Significa que somente pode haver um único titular desse poder, que será sempre o Estado como pessoa jurídica ou aquele poder social que em última instância se exprime, segundo querem alguns publicistas, pela vontade do monarca, da classe ou do povo". Idem. Ibidem.
} 
interno, quer dizer que não existe nenhum poder maior do que o poder político (ele é supremo) e, no externo, que um Estado soberano não admite a interferência, em seu ordenamento, de nenhum outro Estado soberano, daí porque pode-se afirmar que o poder político é independente.

O autor citado cuida, em seguida, do princípio da legalidade e da legitimidade. O primeiro indica que o poder estatal deve sempre agir em conformidade com as leis, que decorrem da Constituição ${ }^{27}$. Ou seja, os atos do governante (detentor do poder), bem como a forma como a sua autoridade sobressai, derivam das normas jurídicas, insertas no Texto Constitucional.

Verifica-se, pois, que o poder e o Direito são dois fenômenos que se desenvolvem conjuntamente. Vale dizer, o poder não cria o Direito, mas naquele poder político - há certa juridicidade. Os fenômenos - poder e Direito - são, pois, concomitantes e, sobre eles, destaca Miguel Reale: “(...) se a atividade política do Estado não é toda jurídica, não é tampouco ajurídica, porquanto devem ser jurídicas as competências de decidir e a forma de exercício". ${ }^{28}$ (grifos do autor)

Pensamos que o Direito não origina o poder estatal (o poder político), mas o seu exercício é pautado pelo Direito, posto que o desenvolvimento do Estado e a relação deste com os membros da comunidade se concretizam através das leis, das normas jurídicas, daquilo que o Direito reconhece. É a norma jurídica que determina o que pode e o que não pode ser feito pelos membros da sociedade. A coerção estatal, aliás, somente será utilizada em último caso, quando tiver havido o total desrespeito às normas jurídicas $^{29}$.

No conceito de legitimidade, por seu turno, “(...) entram as crenças de determinada época, que presidem à manifestação do consentimento e da obediência" ${ }^{30}$,

\footnotetext{
${ }^{27}$ A prevalência da Constituição e a submissão às leis são elementos caracterizadores do Estado de Direito, que nasceu após as revoluções americana e francesa, dando origem aos Estados modernos.

${ }^{28}$ REALE, Miguel. Teoria do direito e do estado. $5^{\mathrm{a}}$ ed. rev. São Paulo: Saraiva, 2000. pp. 117-118.

${ }^{29}$ Ainda acerca da relação entre poder e Direito, complementa Miguel Reale: "Quando dizemos que o poder é jurídico, fazemo-lo relativamente a uma graduação de juridicidade, que vai de um mínimo, que é representado pela força ordenadamente exercida como meio de certos fins, até a um máximo, que é a força empregada exclusivamente como meio de realização do Direito e segundo normas de Direito. Isto quer dizer que o poder não existe sem o direito, mas pode existir com maior ou menor grau de juridicidade. Por outro lado, assim como o poder não existe sem o Direito, o Direito não se positiva sem o poder, um implicando o outro, segundo o princípio de complementariedade, de tanto alcance nas ciências naturais e humanas". Idem. p. 118.

${ }^{30}$ BONAVIDES, Paulo. Op. cit. p. 112.
} 
consoante Paulo Bonavides. Quer isto dizer que a legitimidade não decorre da legalidade e sim de um estágio anterior: do consentimento das pessoas, que aceitam se submeter às normas da sociedade ${ }^{31}$ porque acreditam que esta é o melhor sistema para a proteção da liberdade e da segurança. São as crenças $^{32}$ (e não as leis) que levam, inicialmente, à obediência por parte dos homens.

Apresentadas as características do poder passamos, em seguida, de modo breve, a estudar como se estrutura o poder, apenas na Idade Moderna, porque é neste período que surgem os Estados absoluto e de Direito, contrapondo-se, dessa forma, o poder centralizado ao poder limitado.

\subsection{O poder no Estado moderno}

A Idade Moderna apresenta dois cenários antagônicos: de um lado, o Estado absoluto, caracterizado pela concentração do poder nas mãos do monarca soberano, que se coloca acima da lei, já que neste vige a regra "o Estado sou Eu" e, de outro, o Estado de Direito, fundamentado em uma Constituição e em normas jurídicas criadas pelo próprio Estado, mas com o diferencial de que, neste, os governantes não são irresponsáveis e devem obediência à Constituição, já que esta se apresenta como a norma mais importante do país.

A passagem do Estado absoluto para o de Direito deu-se com as grandes revoluções americana (de 1776) e francesa (de 1789), que culminaram, a primeira, com a independência das colônias americanas do poderio inglês e a promulgação da Constituição Americana de 1787 e, a segunda, com a queda da Bastilha e a promulgação da Constituição de 1791, com o consequente enfraquecimento do poder absoluto do rei. Foi, então, a partir delas, que o Estado absoluto caiu e deu lugar ao Estado de Direito.

\footnotetext{
${ }^{31}$ Cuidando da vida em sociedade, Monica Herman Salem Caggiano explica: "De outra parte, há de se convir que a vida isolada do ser humano é, em regra, impossível. Esse, por sua própria natureza, é compelido a viver em sociedade, a qual lhe oferece a vantagem da cooperação de seus semelhantes na consecução de seus objetivos. Exsurge, assim, o 'homem político' ao qual se refere Robert Dahl, isto é, o homem social que, vivendo numa comunidade, desenvolve sistemas políticos". CAGGIANO, Monica Herman Salem. Oposição... Op. cit. p. 25.

${ }^{32}$ Ainda acerca da legitimidade, esclarece Paulo Bonavides que ela “(...) tem exigências mais delicadas, visto que levanta o problema de fundo, questionando acerca da justificação e dos valores do poder legal. A legitimidade é a legalidade acrescida de sua valoração. É o critério que se busca menos para compreender e aplicar do que para aceitar ou negar a adequação do poder às situações da vida social que ele é chamado a disciplinar”. BONAVIDES, Paulo. Op. cit. p. 112.
} 
Esse fenômeno se espalhou pelo mundo afora. À medida que os países iam se tornando independentes, formavam-se os Estados modernos e, na forma preconizada pelos Estados Unidos da América e pela França, também derrubavam o poder absoluto e adotavam Constituições escritas em seus ordenamentos.

Nascia o Estado de Direito e, com ele, uma nova forma de organização do poder político nos Estados modernos.

Sobre o tema, profere Dalmo de Abreu Dallari:

"Foi a intenção de enfraquecer o poder do Estado, complementando a função limitadora exercida pela Constituição, que impôs a separação de poderes como um dos dogmas do Estado Moderno, chegando-se mesmo a sustentar a impossibilidade de democracia sem aquela separação. Assim é que, já na Declaração de Direitos da Virgínia, de 1776, consta do parágrafo $5^{\circ}$ 'que os poderes executivo e legislativo do Estado deverão ser separados do judiciário". ${ }^{33}$

Por outro lado, Carl Schmitt explica que, inicialmente, o Estado de Direito tem uma conceituação polêmica significando "o contraste frente ao Estado de força - o várias vezes citado contraste entre a liberdade do cidadão e o poder do Estado". 34 Seu sentido preciso aparece quando a ele se ligam os "critérios orgânicos", isto é, a separação de Poderes. Profere o autor que "o fundamento geral da organização segue sendo, naturalmente, o princípio da separação de Poderes". 35

Rodrigo Borja também nos fornece um conceito de Estado de

Direito:

"O movimento do constitucionalismo ${ }^{36}$ produz um tipo especial de Estado - o Estado de Direito ou Estado constitucional - cujas

${ }^{33}$ DALLARI, Dalmo de Abreu. Elementos de teoria geral do Estado. 22a ed. atual. São Paulo: Saraiva, 2001. pp. 218-219.

34 "Estado de Derecho significa el contraste frente al Estado de fuerza - el varias veces citado contraste entre 'liberté du citoyen y gloire de l'état'”. SCHMITT, Carl. Teoría de la Constitución. Traducción de Francisco Ayala. Madrid: Editorial Revista de Derecho Privado, 1934. p. 151.

35 "El fundamento general de la organización sigue siendo, naturalmente, el principio de la distinción de poderes". Idem. Ibidem. Em passagem anterior o autor profere que "El concepto del Estado burgués de Derecho recibe un sentido preciso cuando, no contentándose com los princípios generales de la libertad burguesa y de la defensa del Derecho, se establecen ciertos critérios orgânicos y se sostienen como característicos del verdadero Estado de Derecho". Idem. Ibidem.

${ }^{36}$ Sobre o constitucionalismo profere Rodrigo Borja: "A esta tendencia política moderna a someter el Estado al Derecho se conoce con el nombre de constitucionalismo". BORJA, Rodrigo. Op. cit., p. 309. E continua o autor: "Se propone el constitucionalismo establecer um Estado cuyo gobierno y organización respondan 
características são, não apenas estar submetido por completo às normas jurídicas, mas sobretudo garantir aos indivíduos o mais amplo e livre gozo de seus direitos". ${ }^{37}$ (tradução nossa)

Os dois conceitos nos permitem extrair as características do Estado de Direito: Estado submetido à Constituição e às normas jurídicas do país, que se sobrepõem à vontade do rei; necessária adoção do princípio da separação de Poderes, de modo que as funções do Estado sejam repartidas em executivas, legislativas e judiciárias e proteção dos direitos fundamentais ${ }^{38}$ do homem, de forma que o uso, o gozo e a fruição de seus direitos sejam garantidos independentemente dos desmandos do Estado (que no absolutismo coincidia com o próprio rei). Todas estas características ${ }^{39}$ têm o intuito de limitar o poder do rei que, no Estado absoluto, era irresponsável.

\title{
Gianpaolo Poggio Smanio explica a relação entre Estado de
}

Direito, direitos fundamentais e cidadania. Nas palavras do autor:

\begin{abstract}
"O Estado de Direito é a forma política em que os poderes atuam autônoma e independentemente e submetidos ao império de uma legalidade que garante os direitos fundamentais dos cidadãos. Os direitos fundamentais, por sua vez, legitimam o Estado de Direito e o conteúdo da cidadania. A cidadania é a base de participação política no Estado de Direito, através do exercício dos direitos fundamentais". ${ }^{40}$
\end{abstract}

fielmente a las exigencias de la voluntad general de los gobernados, expresadas mediante normas jurídicas. Se estima que solo así los derechos de las personas están garantizados y el Estado puede marchar ordenada y regularmente bajo el império de la ley, que es expresión de la voluntad general, y no bajo el império de la arbitrariedad". Idem. Ibidem.

37 "El movimiento constitucionalista produjo um tipo especial de Estado - el Estado de Derecho o Estado constitucional - cuyas características son, no sólo estar sometido por completo a normas jurídicas, sino sobre todo garantizar a los individuos el más amplio y libre goce de sus derechos”. Idem. p. 310.

${ }^{38}$ Cláudio Lembo oferece um conceito de direitos fundamentais. Consoante o autor os direitos fundamentais "configuram, hoje, a expressão mais utilizada, apresentando-se insculpida, inclusive, na Constituição brasilelira de 1988. Cabe, portanto, neste primeiro passo, formular uma conceituação inicial: os direitos fundamentais são os direitos naturais da pessoa elevados a nível constitucional, ou seja, positivados pelo legislador constituinte”. LEMBO, Cláudio. A pessoa: seus direitos. Barueri, SP: Manole, 2007. p. 7.

${ }_{39}$ O artigo 16 da Declaração de Direitos do Homem, de 1789, foi incorporado ao texto da primeira Constituição Francesa, de 1791, e determina: "Artigo $16^{\circ}$. Toda sociedade que não assegura a garantia dos direitos, nem determina a separação dos poderes não tem Constituição". Disponível em <http://www.escoladegoverno.org.br/biblioteca/125-declaracao-1789>, acesso em 13 jul. 2011.

${ }^{40}$ SMANIO, Gianpaolo Poggio. A conceituação da cidadania brasileira e a Constituição Federal de 1988. In: MORAES, Alexandre de. (Coord.). Os 20 anos da Constituição da República Federativa do Brasil. São Paulo: Atlas, 2009. p. 334. Ainda discorrendo sobre a cidadania, aliada, agora, à democracia, profere Gianpaolo Poggio Smanio: “A cidadania pressupõe a liberdade para o exercício dos direitos fundamentais. A cidadania é uma condição da pessoa que vive em uma sociedade livre. Onde há tirania não existem cidadãos. A cidadania pressupõe a igualdade entre todos os membros da sociedade, para que inexistam privilégios de classes ou grupos socias no exercício de direitos. Para o exercício das liberdades fundamentais da cidadania, então, é preciso estabelecer uma ordem política democrática que a garanta”. Idem. pp. 334-335. Em outra 
Por outro lado, deve-se atentar para os ensinamentos de Dalmo de Abreu Dallari, no sentido de não se confundir Estado de Direito com Estado arbitrário. Nas palavras do autor:

\begin{abstract}
"Não há dúvida de que a superação do Absolutismo, forma extremada do 'governo de homens', evoluindo para o 'governo de leis', perspectiva de governo justo e responsável, significou um avanço para a Humanidade. Entretanto, é necessária permanente vigilância para que a forma de governo legal não sirva apenas para ocultar a realidade de um governo arbitário, ou seja - lembrando as expressões inglesas consagradas -, para que não se tenha aparente the rule of law e na realidade the law of ruller". 41
\end{abstract}

E continua, explicando que o governo autoritário predominou em diversos momentos, mesmo após o surgimento do Estado de Direito francês em 1791, isto é, sob a aparência de Estado de Direito muitos Estados arbitrários se desenvolveram. Consoante ensina o autor:

\begin{abstract}
"Isso, em grande parte, foi o que ocorreu na França a partir de sua primeira Constituição, de 1791. A Assembléia Nacional foi consagrada como 'fábrica de leis', e os membros da Assembléia eram delegados dos 'cidadãos ativos', categoria social privilegiada, da qual foram excluídos os trabalhadores e as mulheres. O governo de leis, nesse caso, passou a ser, na realidade, o governo dos homens escondidos atrás das leis, criando-se a aparência do Estado de Direito. Essa ilusão do governo limitado e regulado pelo Direito pode ocorrer, e efetivamente ocorre, atualmente, em muitos Estados, quando as leis não são a expressão da vontade do povo, mas apenas veículos formais de imposições arbitrárias dos governantes". ${ }^{2}$
\end{abstract}

obra, contudo, o autor assevera que a cidadania já existia no Estado absoluto, porém, com outro significado. Consoante o autor: "A relação entre o cidadão súdito e o soberano era pensada de forma vertical, entre o sujeito dotado de poder e os sujeitos obrigados a obedecer. No entanto, estes cidadãos sujeitos à autoridade possuiriam uma série de direitos que limitariam o exercício do poder. Além do mais, o soberano devia ao cidadão proteção e justiça. A cidadania era um instrumento para a unificação do Estado Absoluto do século XVI. O indivíduo passava a pertencer a uma determinada esfera jurídica enquanto cidadão do Estado, detentor de um status jurídico que possibilitava o exercício de relações e direitos em relação ao soberano. Os escravos e os estrangeiros não eram considerados cidadãos porque não gozavam dos direitos e privilégios dos cidadãos. As mulheres e as crianças também não eram consideradas cidadãs porque estavam sujeitas ao poder do chefe de família. Somente o indivíduo livre e nacional do Estado era considerado cidadão. SMANIO, Gianpaolo Poggio. As dimensões da cidadania. Revista da Jurídica: novos direitos e proteção da cidadania. Ano 2. São Paulo: Escola Superior do Ministério Público de São Paulo, jan./jun, 2009. p. 13.

${ }^{41}$ DALLARI, Dalmo de Abreu. Estado de Direito e direitos fundamentais. In: FIGUEIREDO, Marcel; PONTES FILHO, Valmir (Org.). Estudos de Direito Público em homenagem a Celso Antônio Bandeira de Mello. São Paulo: Malheiros, 2006. p. 228.

${ }^{42}$ Idem. Ibidem. 
Feita esta observação, partimos para a análise, no tópico seguinte, de uma das formas de limitar e de controlar o poder político: o princípio da separação de Poderes.

\subsection{O princípio da separação de Poderes como fórmula de limitação e de controle do poder político}

Quando se fala em princípio da separação de Poderes, logo nos aflora à mente a famosa tripartição formulada por Montesquieu, em que o exercício do poder político fora distribuído a três órgãos independentes - o Legislativo, o Executivo e o Judiciário -, de modo que a cada um deles foi atribuída uma função típica. Isto ocorreu no início do século XVIII, na Inglaterra.

Embora tenha sido pela obra de Montesquieu que a teoria ficou conhecida, Aristóteles ${ }^{43}$ e John Locke $^{44}$, cada um a seu tempo, contribuíram para a formulação da separação de Poderes, correspondentes às funções do Estado.

${ }^{43}$ A ajuda de Aristóteles veio da Antiguidade. O mestre explicou que o Estado ateniense era composto de "três partes" sendo que "uma dessas tres partes está encarregada de deliberar sobre os negocios publicos; a segunda é a que exerce as magistraturas (...). A terceira é a que administra justiça". ARISTÓTELES. A política. Tradução de Nestor Silveira Chaves. São Paulo: Edições Cultura Brasileira S/A, [s.n]. p. 263. Discorrendo sobre estas funções, Manoel Gonçalves Ferreira Filho afirma, então, que "na república ateniense, com efeito, havia uma Assembléia, à qual era deferida a função deliberativa, numerosos magistrados, que detinham o poder executivo, e juízes independentes que compunham o tribunal, os heliastas". (grifos do autor). FERREIRA FILHO, Manoel Gonçalves. Princípios fundamentais do direito constitucional. São Paulo: Saraiva, 2009. p. 248. Dessa forma, o que se observa é que já Aristóteles previu três funções a serem desempenhadas pelo Estado: a deliberativa, a executiva e a judicial. Havia, porém, uma diferença: em Atenas, a função deliberativa "decide soberanamente da guerra, da paz, da alliança, da ruptura dos tratados, promulga as leis, pronuncia a sentença de morte, o exilio, o confisco, e examina as contas do estado". (grifos nossos). ARISTÓTELES. A política. Op. cit. pp. 263-264. Tal função era, pois, bem mais ampla do que a função legislativa proposta por Montesquieu e, talvez, tenha sido daqui que se originou a necessidade de o Estado prestar contas de seus gastos.

${ }^{44}$ Já no final do século XVII, John Locke, partindo do estado de natureza para a sociedade civil, identificou três funções ao Estado inglês: a legislativa, a executiva e a federativa. Ao Poder Legislativo, formado por diversas pessoas, competia a elaboração das leis que objetivavam o bem público. De se destacar, que para o autor, este poder não precisava continuar funcionando se não tivesse lei a elaborar. Ao Executivo coube garantir a execução das leis pelo tempo que ela durasse, daí porque sua existência, diferentemente do anterior, devia ser contínua. E, ao Federativo coube "fazer a guerra e a paz, ligas e alianças, e todas as transações com todas as pessoas e todas as comunidades que estão fora da comunidade civil". LOCKE, John. Segundo tratado sobre o governo civil e outros escritos: ensaio sobre a origem, os limites e os fins verdadeiros do governo civil. Tradução de Magda Lopes e Marisa Lobo da Costa. $4^{\mathrm{a}}$ ed. Bragança Paulista: Editora Universitária São Francisco; Petrópolis: Vozes, 2006. p. 171. A diferença em relação à teoria clássica da separação de Poderes decorre do fato de que, para John Locke, os Poderes Executivo e Federativo, embora fossem distintos, deveriam ficar juntos. E isto porque a ambos competia o uso da força - característica do Estado - de modo que “(...) é quase impraticável situar a força da comunidade civil em mãos distintas e sem o elo hierárquico; ou que os poderes executivo e federativo sejam confiados a pessoas que possam agir separadamente; isto equivaleria a submeter a força pública a comandos diferentes e resultaria, um dia ou 
A famosa teoria da separação de Poderes, tal como conhecem hoje os Estados contemporâneos, dentre os quais o Brasil, foi formulada por Montesquieu, na Inglaterra do século XVIII, e se apresenta como o marco divisor entre: o governo que centraliza todas as funções em uma só pessoa e o que reparte tal função entre órgãos diferentes; o governante despótico que está acima da lei e o governante que respeita e se subordina às leis; o governante irresponsável e o governante que responde ao povo pelos atos praticados; em suma, entre a concentração e a limitação do poder e, pois, entre o Estado absoluto e o Estado de Direito.

Adílson Abreu Dallari profere sobre o tema:

"O objetivo fundamental da chamada teoria da separação de Poderes ou, mais exatamente, da especificação das funções de cada Poder - é exatamente evitar o absolutismo, o exercício do Poder Político em termos absolutos, sem qualquer limitação, pois isso levaria inevitavelmente à tirania. Evidentemente, não se pode logicamente entender que a tripartição do Poder tenha tido como propósito criar três Poderes absolutamente autônomos e independentes, pois isso corresponderia nada mais, nada menos - a triplicar a tirania. O objetivo fundamental dessa teoria é a criação de instrumentos de contenção do Poder, possibilitando que cada um dos Poderes controle cada um dos outros Poderes". ${ }^{5}$

Sobre a concentração e abuso do poder, preleciona Montesquieu: “todo homem que tem Poder é levado a abusar dele; vai até encontrar os limites. Por isso necessária a divisão dos Poderes. Para que cada Poder freie o outro; impeça o abuso por parte deste. Esse o fundamento da divisão dos Poderes". 46

Para que a separação de Poderes funcione é imprescindível que um Poder controle o outro ou, como prefere Montesquieu, é preciso "dar a um Poder, por assim dizer, um lastro, para pô-lo em condições de resistir a um outro" ${ }^{47}$. Igualmente, Carl

outro, em desordem e ruína". Idem. p. 172. Manoel Gonçalves Ferreira Filho, comentando tais funções, afirma que "fica bem claro que a fórmula de divisão do Poder, que recomenda Locke, não leva em conta rigorosamente as funções que exerce o Estado. Sim, porque a de julgar fica incluída no Legislativo, a de executar é bipartida entre o Executivo e o Federativo". FERREIRA FILHO, Manoel Gonçalves. Princípios... Op. cit. p. 250.

${ }^{45}$ DALLARI, Adílson Abreu. Controle compartilhado da administração da justiça. In: FIGUEIREDO, Marcel; PONTES FILHO, Valmir (Org.). Estudos de Direito Público em homenagem a Celso Antônio Bandeira de Mello. São Paulo: Malheiros, 2006. p. 27.

${ }^{46}$ MONTESQUIEU, Charles-Louis de Secondat, Baron de La Brède et de. O espírito das leis: as formas de governo, a federação, a divisão dos poderes, presidencialismo versus parlamentarismo. Introdução, tradução e notas de Pedro Vieira Motta. $7^{\mathrm{a}}$ ed. São Paulo: Saraiva, 2000. p. 25.

${ }^{47}$ Idem. p. 26. 
Schmitt profere que "a finalidade da sua divisão [de poderes] consiste em que um Poder freie o outro. O Poder pára o Poder. Deste modo se alcança um equilíbrio, um contrapeso". ${ }^{48}$

Montesquieu conclui, então, que o melhor governo é o moderado, isto é, aquele onde existe e se preserva o princípio da legalidade (o "império das leis"), de modo a evitar excessos ou abusos por parte do governante.

Esta teoria é, portanto, uma das técnicas existentes para limitar e controlar o poder e leva em conta o seu critério funcional (das funções que serão atribuídas a cada órgão), o que faz com que Carl Schmitt profira: "é o princípio orgânico [a teoria da separação de Poderes] destinado a assegurar, a colocar em prática, a moderação e o controle de todos os órgãos do poder do Estado". 49 (tradução e grifos nossos)

Ora, o poder político é uno, indivisível ${ }^{50}$ e indelegável. O exercício do poder político, ao contrário, de acordo com Montesquieu, é distribuído a três órgãos distintos (chamados "Poderes"), tendo, cada qual, uma função típica a desempenhar. Ou seja, cada órgão (ou Poder) se especializa em uma função, que é a sua função primordial.

Para o mestre francês, três são os poderes do Estado: “o poder legislativo, o poder executivo das coisas que dependem do direito das gentes e o poder executivo daquelas que dependem do direito civil". 51

Ao primeiro, segundo o doutrinador, foi atribuída a tarefa de fazer as leis; ao segundo, chamado de poder executivo, a função de fazer a guerra e a paz, enviar ou receber embaixadas, garantir a segurança e impedir invasões; e, ao terceiro,

\footnotetext{
48 "La finalidad de su división de las distintas ramas de la actividad del Estado consiste en que un Poder frene a los otros. Le pouvoir arrête Le pouvoir. De este modo há de alcanzarse um equilíbrio, um contra-balanceo". SCHMITT, Carl. Op. cit. p. 214.

49 "Es el principio orgánico destinado a asegurar, ao ponerse em práctica, la moderación y controlabilidad de todos los órganos de poder del Estado". SCHMITT, Carl. Op. cit. p. 212.

${ }^{50}$ Sobre o tema profere Dalmo de Abreu Dallari: 'Embora seja clássica a expressão 'separação de poderes', que alguns autores desvirtuaram para 'divisão' de poderes, é ponto pacífico que o poder do Estado é uno e indivisível. É normal e necessário que haja muitos órgãos exercendo o poder soberano do Estado, mas a unidade do poder não se quebra por tal cirscunstância”. DALLARI, Dalmo de Abreu. Elementos... Op. cit. pp. 215-216.

${ }^{51}$ MONTESQUIEU, Charles-Louis de Secondat, Baron de La Brède et de. O espírito das leis. Apresentação de Renato Janine Ribeiro. Tradução de Cristina Murachco. $3^{\mathrm{a}}$ ed. São Paulo: Martins Fontes, 2005. p. 167.
} 
denominado poder judiciário, a incumbência de resolver os crimes e dirimir os conflitos entre os particulares. ${ }^{52}{ }^{53}$

Trazidos para a realidade brasileira, ao Poder Legislativo competem as funções de elaborar a lei e a do controle financeiro, primordialmente; ao Poder Executivo, a aplicação da lei; e ao Judiciário a função de dirimir os conflitos surgidos. No século XXI, passa o Judiciário a desenvolver, ainda, o ativismo judicial, em que pese não seja esta sua função típica.

Por outro lado, para que a teoria funcione, não é possível que os poderes sejam estanques, isto é, que cada um exerça a sua função típica com exclusividade. Se isso fosse cabível, poderia acarretar a deterioração da teoria, na medida em que um Executivo muito forte poderia fechar o Parlamento e um Legislativo muito forte poderia impedir o Executivo de governar. Dessa forma, surgem as funções atípicas ${ }^{54}$, através das quais cada Poder pode - e deve - desempenhar as funções dos outros dois, mas de maneira menos usual.

Delimitadas estas três funções típicas, mister, ainda, que elas sejam independentes umas das outras, vale dizer, que inexista subordinação de uma em relação às demais. Também em nome da independência devem ser asseguradas prerrogativas e imunidades ${ }^{55}$ aos membros dos Poderes e à própria instituição.

Outra característica integrante da teoria é a harmonia entre os Poderes, ou seja, devem eles cooperar, agir em conjunto para que as finalidades do Estado sejam alcançadas e não atuar de modo a impedir que cada um cumpra suas funções.

\footnotetext{
${ }^{52}$ Montesquieu explica cada uma das funções: "Com o primeiro [poder legislativo], o príncipe ou o magistrado cria leis por um tempo ou para sempre e corrige ou anula aquelas que foram feitas. Com o segundo [poder executivo], ele faz a paz ou a guerra, envia ou recebe embaixadas, instaura a segurança, previne invasões. Com o terceiro [poder judiciário], ele castiga os crimes, ou julga as querelas entre os particulares". Para maiores detalhes consultar: MONTESQUIEU, Charles-Louis de Secondat, Baron de La Brède et de. Idem. pp. 167-168.

${ }^{53}$ Montesquieu repudia, assim, que os Poderes Legislativo e Executivo sejam reunidos em uma só pessoa porque, neste caso, não haveria liberdade para o homem, uma vez que o governante poderia criar e executar leis tirânicas. Por outro lado, também não se consente a reunião do Poder Legislativo com o Judiciário, pois inexistiria liberdade, uma vez que o juiz seria também o legislador. Da mesma forma, a junção do Poder Executivo com o Judiciário não é possível, uma vez que o juiz poderia agir como opressor. Para maiores detalhes consultar: MONTESQUIEU, Charles-Louis de Secondat, Baron de La Brède et de. Idem. p. 168.

${ }^{54}$ Assim, por exemplo, no Brasil, o Legislativo julga o Chefe do Executivo no crime de impeachment; o Chefe do Executivo legisla através da lei delegada e o Judiciário administra ao dar férias a um funcionário seu.

${ }^{55} \mathrm{~A}$ respeito das prerrogativas e imunidades de cada Poder que é reflexo de sua independência, consultar os seguintes artigos da Constituição Federal de 1988: 53, caput; 53, § 1º ;4, I e II (para o Legislativo); 95, I a III (para o Judiciário); e 84 (para o Executivo).
} 
Há que se falar, ainda, nos freios e contrapesos $^{56}$ (checks and

balances), pelos quais um Poder deve controlar o outro, um deve frear o outro, para que abusos não sejam praticados. Acerca da vinculação desses freios e contrapesos com a impossibilidade do total isolamento entre os Poderes, profere Carl Schmitt:

\begin{abstract}
"Separação e contrapesos de Poderes. A distinção de Poderes tem que considerar dois pontos de vista: primeiro, a introdução de uma separação das autoridades superiores do Estado e de sua competência; depois, o estabelecimento de uma vinculação de influências e contrapesos recíprocos das faculdades destes "poderes" diferenciados. Uma certa separação é necessária e com ela se faz possível uma diferenciação. Se bem que não cabe praticar um isolamento pleno e absoluto, portanto, é preciso considerá-lo, não obstante, como ponto de vista independente dentro deste princípio de organização". ${ }^{57}$ (tradução nossa)
\end{abstract}

Extrai-se que o autor difere a separação total do isolamento entre os Poderes. A separação é necessária para que o poder político possa ser controlado. Entretanto, é preciso que os Poderes se relacionem, sob pena de os abusos também serem praticados. O objetivo dos freios e contrapesos ${ }^{58}$ é, portanto, permitir o equilíbrio entre os Poderes, por meio do qual um Poder fiscaliza o outro.

Antes de entrarmos no estudo de cada um dos Poderes e de suas funções, é preciso fazer uma distinção conceitual, que se segue.

\footnotetext{
${ }^{56}$ A validade dos freios e contrapesos, no ordenamento pátrio, pode ser traduzida pela faculdade de o Chefe do Poder Executivo vetar um projeto de lei; de o Poder Judiciário declarar a inconstitucionalidade de uma lei que fere a Constituição; e de o Poder Legislativo, através do Senado Federal, sabatinar o futuro Ministro do Supremo Tribunal Federal, escolhido pelo Chefe do Executivo, como condição para a nomeação daquele.

57 "Separación y contrapeso de poderes. En la distinción de poderes hay que considerar dos puntos de vista: primero, la introducción de una separación de las autoridades superiores del Estado y de su competencia; después, el establecimiento de una vinculación de influjo y contrapeso recíprocos de las facultades de estos "poderes" diferenciados. Una cierta separación es necesaria, y con ella se hace posible una diferenciación. Si bien no cabe practicar un pleno y absoluto aislamiento, por lo pronto es preciso considerarlo, no obstante, como punto de vista independiente dentro de este principio de organización". SCHMITT, Carl. Op. cit. p. 216.

${ }^{58}$ Sobre os freios e contrapesos, explica Nelson Saldanha que eles tiveram origem nos "checks and balances" da Constituição britânica, durante os séculos XVIII e XIX. A mesma ideia, conhecida como "pouvoirs", também esteve presente na França, tendo sido utilizada por Montesquieu. Aduz, ainda, o autor, sobre os freios e contrapesos: “os 'contrapesos' freiam os excessos governamentais em sentido equivalente ao da limitação recíproca que a 'separação' francesa oferece. Trata-se de não permitir nem a invasão de atribuições nem o seu enfeixamento numa só mão ('ai da infeliz vítima - dizia um personagem do 'Maria Stuart de Schiller - se a mesma boca que dita a lei profere a sentença'), embora o primeiro ponto, o do impedimento às invasões recíprocas, se achasse mais nítido nos enunciados franceses". SALDANHA, Nelson. O estado moderno e a separação de poderes. São Paulo: Saraiva, 1987. p. 115.
} 


\subsubsection{O Poder Legislativo: órgão de controle}

O Poder Legislativo é, por excelência, um órgão de controle.

As primeiras notícias a respeito do Parlamento datam da Idade Média e têm sede na Inglaterra onde lhe competia uma função meramente consultiva. Em 1215, com a Magna Carta, o Parlamento conquista o poder tributário, cabendo-lhe a instituição dos impostos ${ }^{59}$. A partir de $1265^{60}$ os seus membros passaram a se reunir periodicamente com o rei. O sistema bicameral, por seu turno, remonta ao ano de 1351, ocasião em que foi configurado pela primeira vez ${ }^{61}$. Posteriormente, em 1462, o Parlamento ganha outra função, a da elaboração das "bills" (leis) que, aprovadas pelas duas Casas do Parlamento, eram submetidas ao rei, que só podia ratificá-las ${ }^{62}$.

\section{Observa-se, desde seus primórdios, a função de controle do}

Parlamento perante o rei e, hoje, frente ao Executivo.

Foi o Estado de Direito, no século XVIII, no entanto, que proporcionou o fortalecimento da instituição parlamentar, na medida em que "o direito divino em que se sustentava o poder dos reis foi sendo substituído pelo direito positivo elaborado pelo Parlamento". ${ }^{63}$ (tradução nossa).

O que se observa é que não bastava mais a explicação de que o rei era o filho de Deus na terra, para que o soberano pudesse mandar e desmandar. Ele encontrou um limite: as normas positivadas na Constituição e provenientes do Parlamento, momento em que prolifera, em tal órgão, a função legislativa. Nesse sentido, a partir do

\footnotetext{
${ }^{59}$ Monica Herman Salem Caggiano explica que a origem embrionária do Parlamento se encontra no período medieval inglês, onde um conselho feudal, formado por vassalos e com atribuição meramente consultiva, reunia-se para deliberar com o rei. Este Conselho deu origem ao Magnum Concilium (Conselho Comum do Rei) e, em 1215 foi incorporado na Magna Carta com a "competência para participar da imposição tributária e para apresentar petições ao rei". CAGGIANO, Monica Herman Salem. Direito parlamentar e direito eleitoral. Barueri, SP: Manole, 2004. p. 7. Para detalhes, consultar, ainda: CAGGIANO, Monica Herman Salem. Direito parlamentar e direito eleitoral. Barueri, SP: Manole, 2004. p. 12.

${ }^{60}$ Ainda de acordo com Monica Herman Salem Caggiano, "a certidão de nascimento do Parlamento" ocorreu em 1265, ano em que "Simon de Monfort convoca dois cavalheiros de cada condado para participar do Grande Concilium, ao lado dos prelados e barões, procedimento que ingressa numa linha de regularidade com Eduardo I (1295)". CAGGIANO, Monica Herman Salem. Direito... Op. cit. p. 7.

${ }^{61}$ Mais tarde, no século XIII, há a convocação da assembleia e é em 1351 que surge o sistema bicameral do parlamento britânico, formado por duas Câmaras: a dos Lordes e a dos Comuns. Para maiores detalhes, consultar: Idem. Ibidem.

${ }_{62}^{62}$ Para detalhes, consultar: CAGGIANO, Monica Herman Salem. Direito... Op. cit. p. 10.

${ }^{63}$ "Fue entonces cuando el derecho divino en que se sustentaba el poder de los reyes fue siendo sustituido por el derecho positivo, elaborado por el parlamento". VALENZUELA, Francisco Berlín. Derecho parlamentario. $4^{\mathrm{a}}$ reimpresión. México: Fondo de Cultura Económica, 2000. p. 128.
} 
Estado de Direito, o Parlamento se fortaleceu, de modo que muitas das brigas entre este e o monarca terminaram com o enfraquecimento e até mesmo a deposição do segundo.

Consolidado, o Parlamento apresenta-se na Idade Contemporânea como um órgão político, em sua maioria bicameral ${ }^{64}$, que reúne os representantes de todas as camadas sociais e com o objetivo de decidir as políticas que serão adotadas para a condução do país. Denota-se, assim, a relevância da instituição.

Visto como se deu o aparecimento do Parlamento, podemos, agora, trazer uma definição da instituição. Adotamos o conceito de Francisco Berlín Valenzuela para o qual:

\begin{abstract}
"Como é sabido, o Parlamento é um órgão político colegiado, de caráter representativo em que recaem as funções mais elevadas da direção do Estado e que, além da função de elaborar leis, exerce - entre outras - a de controlar os atos dos governantes, de acordo com as constituições e com o sistema político em que atua". (tradução e grifos nossos) ${ }^{65^{3}}$
\end{abstract}

Nossa escolha por esta definição deve-se ao fato de que ela reúne os elementos essenciais do Parlamento (ou do Poder Legislativo ${ }^{66}$ ): órgão político colegiado, de caráter representativo e que tem, como uma de suas funções primordiais, controlar os atos dos governantes, de acordo com o disposto na Constituição do país.

\footnotetext{
${ }^{64}$ A Constituição Peruana de 1993, elaborada à época em que Alberto Fujimori era Presidente e vigente até hoje dispõe, em seu artigo 90, que o Legislativo apresenta-se em sua forma unicameral. Tal ocorreu com o objetivo de facilitar o controle da Câmara única pelo Poder Executivo, já que a Constituição de 1993 foi resultado do golpe militar dado por Alberto Fujimori. Consoante já tive a oportunidade de esclarecer, "as críticas ao sistema unicameral residem na dificuldade que o Poder Legislativo enfrenta ao executar suas tarefas típicas. É que, sem a outra Câmara, para realizar o controle interno, a elaboração e a aprovação das leis ressentem-se de solidez e, ainda, a função de fiscalização que o Poder Legislativo exerce sobre os demais Poderes pode não ocorrer, bastando, para tal, que o governo detenha a maioria parlamentar na única Câmara". FAGUNDES, Tatiana Penharrubia. Reforma política no Peru. Cadernos de Pós-Graduação em Direito: estudos e documentos de trabalho. Tendências e desafios do constitucionalismo latino-americano. n. 3. São Paulo: Comissão de Pós-Graduação da Faculdade de Direito da USP, 2011. p. 80.

65 “Como es sabido, el parlamento es un órgano político colegiado, de carácter representantivo en el que recaen las funciones más elevadas de la dirección del Estado y quien, además de la función creadora de leyes, ejerce - entre otras - la de controlar los actos de los gobernantes, de acuerdo con las constituciones y con el sistema político en que actúa". VALENZUELA, Francisco Berlín. Op. cit. pp. 127-128.

${ }^{66}$ Poder Legislativo é sinônimo de Parlamento, consoante assevera Francisco Berlín Valenzuela. O autor explica, ainda, que a palavra Parlamento vem do baixo latim parabolare ("falar") e do termo francês parlement, com o mesmo significado. A assembleia, por seu turno, é proveniente do baixo latim atsibulare (reunir simultaneamente), significando várias pessoas que se reúnem para decidir algum assunto. Não é palavra exclusiva do direito, daí porque, a assembleia parlamentar (esta relacionada ao Direito) tem como função principal elaborar a lei. Para maiores detalhes, consultar: Idem. VALENZUELA, Francisco Berlín. Derecho parlamentario. $4^{\text {a }}$ reimpresión. México: Fondo de Cultura Económica, 2000. p. 127.
} 
A função de controle é tão importante que José Afonso da Silva, após explicar que as funções do Poder Legislativo são aquelas "que se atribuem aos órgãos desse Poder"67 e de elencá-las como sendo as de representação, de legislação, de legitimação da atuação governamental e de controle, assevera, ainda, que:

"Se formos buscar no recesso da história a explicação e os fundamentos do Poder Legislativo, poderíamos até dizer que todas as suas funções são de controle, porque se desenvolveu como órgão de representação destinado a controlar o poder do soberano" ${ }^{68}$ (grifos nossos)

Importante esta conclusão: o Poder Legislativo tem, desde o seu nascimento, o objetivo de controle do governo. E, uma das formas deste controle consiste, no ordenamento pátrio e em cenário municipal, no julgamento, pela Câmara dos Vereadores, das contas municipais, fazendo-o juntamente com o Tribunal de Contas, matéria que constitui o cerne do nosso trabalho.

\subsubsection{O Poder Executivo}

Enquanto o século XIX representou o auge do Poder Legislativo, graças à importância conferida ao princípio da legalidade, o século $\mathrm{XX}$, por seu turno, especialmente após a Primeira Guerra Mundial, colocou o Poder Executivo no ponto mais alto do cenário político. E isto se deu em face do desenvolvimento do Welfare State (o Estado de Bem-Estar Social), que requereu ações intervencionistas do Estado para a concretização de políticas públicas em prol dos hipossuficientes. Estas políticas materializaram-se nos planos assistencialistas de Governo, como nas áreas econômica e financeira e, ainda, em medidas para a consecução dos direitos fundamentais básicos de segunda dimensão, como saúde e educação. Consoante Cláudio Lembo, "os direitos sociais exigem prestações do Estado. Aqui se quer o Estado ativo, buscando afastar as iniqüidades sociais e oferecer condições de sobrevivência para as pessoas (alimento, moradia, educação, lazer, saúde, entre outros)". ${ }^{69}$

${ }^{67}$ SILVA, José Afonso da. Processo constitucional de formação das leis. $2^{\mathrm{a}}$ ed. $2^{\mathrm{a}}$ tiragem. São Paulo: Malheiros, 2007. p. 57.

${ }^{68}$ Idem. Ibidem.

${ }^{69}$ LEMBO, Cláudio. A pessoa...Op. cit. p. 16. 
Tudo isso demandou a participação efetiva do Chefe do Executivo porque “(...) sua estrutura concentrada lhe permitia as decisões prontas que nesses campos são necessárias". ${ }^{70}$

Um ponto negativo do Welfare State e do fortalecimento da figura do Presidente para a consecução dos direitos de segunda dimensão foi entender que a cidadania só se alcançaria através das medidas adotadas pelo Poder Executivo. Gianpaolo Poggio Smanio é quem explica:

"Uma conseqüência do desenvolvimento da cidadania entre nós é a excessiva valorização do Executivo, uma vez que são os governos que 'concederam' os direitos sociais. Este processo traz uma visão paternalista, de troca de favores, para ganhar benefícios, trazendo também o messianismo, a busca pelo 'salvador da pátria', tão presente entre nós. Na feliz expressão de José Murilo de Carvalho, o que prevalece no Brasil é a 'estadania', ao invés da cidadania, o que dificulta a organização autônoma de nossa sociedade". ${ }^{71}$ (grifos nossos)

Versando sobre o tema do Estado de Bem-Estar Social, assevera

Marcelo Figueiredo:

"O Estado Social, em uma palavra, foi uma tentativa mundial de não só abrandar as desigualdades sociais, mas sobretudo compreender que o Estado não se limita a garantir direitos, mas principalmente a proporcioná-los. Assim, de 1793 a 1848, na França, grande avanço deu-se no tocante ao direito ao trabalho e no dever de o Estado prestá-lo a todos. Os direitos sociais afirmavam-se". ${ }^{72}$

\section{E continua o Professor:}

“Ademais, era preciso que, além da igualdade jurídica, se estendesse aos homens também a igualdade econômica. Surge a ordem econômica e social como capítulo constitucional. As Constituições de 1917 e 1919 respectivamente do México e Weimar são representativas do período". ${ }^{73}$

\footnotetext{
${ }^{70}$ FERREIRA FILHO, Manoel Gonçalves. Curso de direito constitucional. $34^{\mathrm{a}}$ ed. rev. e atual. São Paulo: Saraiva, 2008. p. 221.

${ }_{71}^{71}$ SMANIO, Gianpaolo Poggio. A conceituação... Op. cit. p. 339.

72 FIGUEIREDO, Marcelo. A crise no entendimento clássico do princípio da legalidade administrativa e temas correlatos. In: FIGUEIREDO, Marcelo; PONTES FILHO, Valmir (Org.). Estudos de Direito Público em homenagem a Celso Antônio Bandeira de Mello. São Paulo: Malheiros, 2006. p. 432.

${ }^{73}$ Idem. Ibidem.
} 
Entendia-se, nessa seara, que ninguém melhor do que o Presidente da República para garantir a igualdade econômica de que trata o autor precitado. O Presidente passa, então, a praticar ações intervencionistas que visam a promover bem-estar para a classe mais carente. Daí a força da pessoa do Presidente da República.

A preponderância do Poder Executivo foi resultado, ainda, da supremacia dos partidos políticos, de modo que "o poder passa a ser exercido sob a liderança da agremiação partidária alçada ao pólo do Executivo (...)" ${ }^{74} \mathrm{O}$ poder político e as decisões políticas são tomados pelo grupo que venceu as eleições, de modo que tal grupo "passa a dominar o Executivo e o Legislativo, sob o controle indisfarçável do primeiro". 75

Mais tarde, observa-se o ressurgimento do Legislativo, através de sua função típica de controle e, posteriormente, uma nova hegemonia do Executivo, motivada, conforme Monica Herman Salem Caggiano, pela “(...) própria banalização dos instrumentos de controle [do Poder Legislativo] e a sua manipulação perseguindo interesses pessoais ou de grupos passou a realimentar o domínio do Executivo em cena política e a retomada da fase de dormência parlamentar, sob o comando camuflado ou não do Executivo" ${ }^{\text {76 }}$ (grifos da autora).

Esta preponderância do Executivo é sentida no Brasil e, em especial, no que tange à matéria financeira, pois compete ao Chefe do Executivo e aos administradores públicos, após aprovada a lei orçamentária, usar o dinheiro público para a construção de casas, escolas, distribuição de remédios e etc, determinando a aplicação dos recursos às políticas sociais que entenderem necessárias, devendo, no entanto, tais gestores, prestar contas ao Poder Legislativo, por intermédio do Tribunal de Contas, incidindo sobre eles, no caso de rejeição das contas, as sanções decorrentes da má utilização do dinheiro. E isto porque quem usa o dinheiro público se responsabiliza pela sua boa utilização.

\footnotetext{
74 CAgGiano, Monica Herman Salem. A emergência do Poder Judiciário como contraponto ao bloco monocolor Legislativo/Executivo. In: MORAES, Alexandre de. (Coord.). Os 20 anos da Constituição da República Federativa do Brasil. São Paulo: Atlas, 2009. p. 100.

${ }^{75}$ Idem. Ibidem.

${ }^{76}$ Idem. p. 101.
} 


\subsubsection{O Poder Judiciário: outro órgão de controle}

O Poder Judiciário, na teoria de Montesquieu, foi considerado como um poder quase nulo ${ }^{77}$. Isto porque a ele competia a função de ser "a boca que pronuncia as palavras da lei ${ }^{, 78}$, restringindo a função do juiz a mero aplicador ${ }^{79}$ das leis elaboradas pelo Legislativo. Não havia, assim, muita diferença entre ele e o Executivo, que também aplicava a lei. Ademais, o juiz não participava e não influenciava na escolha das decisões políticas e nos destinos do Estado, que eram atribuições do Executivo e do Legislativo, que deveriam frear-se mutuamente.

$\mathrm{Na}$ atualidade, ao Poder Judiciário compete a função jurisdicional cabendo-lhe dizer o direito no caso concreto. Ocorre que, para exercê-la, às vezes é preciso manifestar-se sobre uma determinação dada por outro Poder. Neste caso, Manoel Gonçalves Ferreira Filho assevera que o Judiciário "não o faz, contudo, para controlar, fiscalizar este outro Poder, mas apenas para assegurar o império da lei". ${ }^{80}$ Age, nestas situações, como o "guardião da legalidade".

Ressalte-se, ainda, que a decisão judicial tem caráter de definitividade, o que não ocorre com as proferidas em âmbito administrativo. Ademais, a definitividade é reforçada pela garantia constitucional inserta no artigo $5^{\circ}, \mathrm{XXXV}$, segundo o qual "a lei não excluirá da apreciação do Poder Judiciário lesão ou ameaça a direito" Significa que qualquer pessoa que se sentir ameaçada ou violada em seus direitos pode recorrer ao Poder Judiciário ainda que seja portadora de uma decisão dada em âmbito administrativo. É garantia constitucional concernente ao princípio da inafastabilidade do Poder Judiciário.

\footnotetext{
${ }^{77}$ De acordo com o autor, “(...) o Poder de Julgar, tão terrível entre os homens, não estando ligado nem a um certo estado, nem a uma certa profissão, torna-se, por assim dizer, invisível e nulo". In: MONTESQUIEU, Charles-Louis de Secondat, Baron de La Brède et de. O espírito das leis: as formas de governo, a federação, a divisão dos poderes, presidencialismo versus parlamentarismo. Introdução, tradução e notas de Pedro Vieira Motta. $7^{\text {a }}$ ed. São Paulo: Saraiva, 2000. p. 170.

${ }^{78}$ Idem. p. 55.

${ }^{79}$ Os julgamentos mais graves não eram atribuídos ao Judiciário e sim à Câmara Alta, que corresponde ao nosso Senado.

${ }^{80}$ FERREIRA FILHO, Manoel Gonçalves. Poder Judiciário na Constituição de 1988: judicialização da política e politização da justiça. In: FERREIRA FILHO, Manoel Gonçalves. Aspectos de direito constitucional contemporâneo. $2^{\mathrm{a}}$ ed. São Paulo: Saraiva, 2009. p. 192.

${ }^{81}$ BRASIL. Constituição (1988). Constituição da República Federativa do Brasil: promulgada em 5 de outubro de 1988: atualizada até a Emenda Constitucional n ${ }^{\circ}$ 67, de 22-12-2010. 45 a ed. ampl. São Paulo: Saraiva, 2011. p. 7.
} 
Dessa forma, em matéria financeira, é possível ao Chefe do Executivo ou àquele que teve suas contas rejeitadas pelo Tribunal de Contas recorrer ao Poder Judiciário contra tal decisão. Isto quer dizer que a determinação do Tribunal de Contas, em que pese não possa ter o seu mérito reapreciado ou modificado pelo juiz, carece de definitividade, que somente será encontrada no Poder Judiciário, em razão do princípio constitucional referido.

Por outro lado, também se insere como atribuição do Poder Judiciário a guarda da Constituição, tarefa que é desempenhada através do controle de constitucionalidade das normas. Ampliam-se, assim, as atribuições do Judiciário, na medida em que deixa de resolver apenas os conflitos decorrentes de casos concretos e passa a analisar as ações abstratas, com eficácia erga omnes. Torna-se, pois, um órgão de controle.

Tratando deste papel de controle de constitucionalidade no direito norte-americano, Monica Herman Salem Caggiano afirma que ao Poder Judiciário foi destinado “(...) um papel político-jurisdicional que se materializa no âmbito do controle jurisdicional de constitucionalidade das leis ou das decisões políticas". ${ }^{82}$

Vê-se, então, que "de poder quase nulo", assim considerado por Montesquieu, o Judiciário se transformou em Poder essencial para a salvaguarda dos direitos fundamentais do homem e para a proteção da lei e da Constituição.

\subsubsection{O fenômeno da "judicialização da política"}

Enquanto o século XIX foi marcado pela preponderância do Poder Legislativo (império da lei) e o século XX teve o Poder Executivo como destaque para a implantação das políticas públicas, o século XXI passa a ser o "século" do Poder Judiciário. É que, além da função típica clássica de dizer o direito no caso concreto, de modo a assegurar o império da lei (agindo, pois, como o "guardião da legalidade") assume agora, também, o papel de "guardião da legitimidade" e, como tal, coloca-se lado a lado com o Legislativo e o Executivo, realizando o controle judicial sobre as ações dos poderes públicos. Reequilibra, pois, as funções clássicas.

${ }^{82}$ CAGGIANO, Monica Herman Salem. A emergência... Op. cit. p. 103. 
Atuando como "guardião da legitimidade", as tensões antes havidas no bloco Legislativo/Executivo mudam de eixo e se estabelecem, a partir daí, entre o Legislativo/Judiciário e o Executivo/Judiciário. Quanto à atuação como "guardião da legitimidade”, profere Manoel Gonçalves Ferreira Filho que ela constitui-se em "um efeito perverso - reflexo imprevisto de institutos adotados como inovações positivas exatamente o de judicializar o tratamento de questões políticas ou político-administrativas e, conseqüentemente, de dar uma dimensão política à atuação desse Poder, até então visto como "neutro",. 83

O Judiciário sai, então, do papel de neutralidade, caracterizado por Montesquieu e assume posição ativista na relação com os demais poderes. Surgem novas tensões. Assim é que a questão que envolve estes novos núcleos de conflito diz respeito a determinar até que ponto o Judiciário pode escolher a política pública que será adotada no país - decisão que competia, primordialmente, ao Executivo - e, até mesmo, em que medida está autorizado a criar normas, substituindo o legislador (lembre-se do caso da lei de greve do setor público civil) ou declarar inconstitucional uma lei, também aqui em detrimento da vontade do legislador. Esta nova atuação do Poder Judiciário vem sendo chamada de "judicialização da política".

E, na "judicialização da política", o Poder Judiciário assume um papel de comando frente aos outros Poderes, de modo que quando se fala em "controle" que este Poder exerce, o seu significado é proveniente do direito inglês ( "control") e quer dizer dominação, o que não se confunde com o "contrôle" do direito francês, que significa fiscalização.

Cláudio Lembo, em suas preciosas lições, explica o fenômeno da “judicialização da política:

\footnotetext{
"Com surpresa, alguns setores da sociedade recebem essa nova configuração do Judiciário. Um poder ágil, capaz de entender anseios coletivos. Situações não previstas nas rígidas regras contidas na legislação clássica.

É um mundo aparentemente novo. A isto muitos dão o nome de politização do Judiciário. Pode ser. Um poder, que deseja influir e expõe
}

${ }^{83}$ FERREIRA FILHO, Manoel Gonçalves. Poder Judiciário... Op. cit. p. 190. 
o seu pensamento de maneira diversa do esperado, está exercendo ação política". ${ }^{84}$ (grifos nossos)

Há diversos exemplos da "judicialização da política" no Brasil, como a decisão do Supremo Tribunal Federal que reconheceu o direito de greve aos servidores públicos civis ${ }^{85}$, bem como as inúmeras determinações do Tribunal Superior Eleitoral quanto a temas como verticalização (que se materializaram por simples resoluções) ou fixação do número máximo de vereadores para os Municípios.

No que tange ao nosso tema, observamos a atuação do Poder Judiciário na questão relativa à inelegibilidade do Chefe do Executivo quando este figurar como Ordenador da despesa. $\mathrm{E}$ isto porque a Lei Complementar $\mathrm{n}^{\mathrm{o}} 135 / 10$, que deu nova redação à Lei Complementar $\mathrm{n}^{\circ}$ 64/90, modificou o artigo 1', I, "g", autorizando a aplicação da sanção de inelegibilidade por oito anos "a todos os ordenadores de despesa, sem exclusão de mandatários que houverem agido nessa condição" quando estes tiverem suas contas rejeitadas "por irregularidade insanável que configure ato doloso de improbidade administrativa, e por decisão irrecorrível do órgão competente, salvo se esta houver sido suspensa ou anulada pelo Poder Judiciário". Por conta desta lei, diversos Prefeitos ficaram inelegíveis em face das condenações proferidas pelos Tribunais de Contas a que eles estavam adstritos. Recorreram, por óbvio, ao Judiciário, visando a anular ou a suspender a decisão das Cortes de Contas.

Por esta razão, diversos recursos foram apreciados pelo Tribunal Superior Eleitoral. Em um deles, o Agravo Regimental no Recurso Ordinário no 4417-

\footnotetext{
${ }^{84}$ LEMBO, Cláudio. Visões do cotidiano. Barueri, São Paulo: Manole, 2012. p. 62.

${ }^{85}$ Um destes exemplos é o Mandado de Injunção no 670-9 pelo qual o Supremo Tribunal Federal adotou a tese, até então minoritária, no sentido de reconhecer, por maioria, a omissão legislativa quanto à necessidade de regulamentação do direito de greve aos servidores públicos civis e aplicar (esta é a novidade), a tais servidores civis, no que couber, a Lei $\mathrm{n}^{\mathrm{o}} 7.783$, de 28 de junho de 1989, que cuida do direito de greve para o setor privado. A decisão do STF, em julgamento do Pleno, no dia 25 de outubro de 2007, no Mandado de Injunção no 670-9 - Espírito Santo, impetrado pelos Servidores Policiais Civis do Estado do Espírito SantoSINPOL em face do Congresso Nacional foi a seguinte: "Decisão: O Tribunal, por maioria, nos termos do voto do Relator, conheceu do mandado de injunção e propôs a solução para a omissão legislativa com a aplicação da Lei $\mathrm{n}^{\mathbf{0}}$ 7.783, de 28 de junho de 1989, no que couber, vencidos, parcialmente, os Senhores Ministros Ricardo Lewandowski, Joaquim Barbosa e Marco Aurélio, que limitavam a decisão à categoria representada pelo sindicato e estabeleciam condições específicas para o exercício das paralisações. Votou a Presidente, Ministra Ellen Gracie. Não votou o Senhor Ministro Menezes Direito por suceder ao Senhor Ministro Sepúlveda Pertence, que proferiu voto anteriormente. Ausente, justificadamente, a Senhora Ministra Cármen Lúcia, com voto proferido em assentada anterior. Plenário, 25.10.2007”. Rel. Originário Min. Maurício Corrêa. Rel. para acórdão Min. Gilmar Mendes. Tribunal Pleno. Julgado em 25/10/07. Para maiores informações, consultar <http://www.stf.gov.br/portal/processo/verProcessoAndamento.asp?numero=712\&classe=MI\&origem=AP\& recurso=0\&tipoJulgamento=M>, acesso em 05 de abr. 2008.
} 
24.2010.6.15.000 ${ }^{86}$ - Classe 37 - João Pessoa - Paraíba, a Corte, por maioria, entendeu que o órgão competente para o julgamento das contas do Chefe do Executivo municipal -, quando este figurar como ordenador da despesa -, é o Poder Legislativo e não o Tribunal de Contas, não se aplicando a ele a inelegibilidade prevista na alínea "g" do inciso I do artigo $1^{\circ}$ da Lei Complementar $n^{\circ}$ 64/90, com redação dada pela Lei Complementar $n^{\circ}$ $135 / 10^{87}$. O Relator, Senhor Ministro Hamilton Carvalhido, aduziu que de acordo com o artigo 31 da Lei Maior, o julgamento das contas do Prefeito é de responsabilidade da Câmara Municipal, cabendo ao Tribunal de Contas elaborar um parecer prévio, de modo que este, ainda que rejeite as contas prestadas pelo Prefeito, como ordenador da despesa, não tem o condão de causar a inelegibilidade do Chefe do Executivo local, o que somente poderá ocorrer no caso da confirmação da rejeição das contas pela Câmara Municipal. Dessa forma, manifestou-se no sentido de que a expressão “aplicando-se o disposto no inciso II do art. 71 da Constituição Federal, a todos os ordenadores de despesa, sem exclusão de mandatários que houverem agido nessa condição" (artigo 1º, I, "g", da Lei Complementar $n^{\circ}$ 64/90, com redação dada pela Lei Complementar $n^{\circ} 135 / 10$ ) não inclui o Chefe do Executivo, ainda que ele figure como ordenador da despesa ${ }^{88}$.

\footnotetext{
${ }^{86} \mathrm{O}$ Tribunal Superior Eleitoral firmou entendimento de que a inelegibilidade inserta na parte final do artigo $1^{\circ}$, inciso I, alínea "g", da Lei Complementar no 64/90, com redação dada pela Lei Complementar no 135/10 não se aplica ao Chefe do Executivo quando ele for ordenador da despesa, salvo no caso do inciso VI, do artigo 71, da Constituição Federal. BRASÍLIA (BR). Lei Complementar nº 64, de 18 de maio de 1990. Estabelece, de acordo com o art. $14, \S 9^{\circ}$ da Constituição Federal, casos de inelegibilidade, prazos de cessação, e determina outras providências. Diário Oficial da União de 21 de maio de 1990.

${ }^{87}$ Dispõe o artigo $1^{\circ}$, I, "g", da Lei Complementar no 64/90, com redação dada pela Lei Complementar ${ }^{\circ}$ 135/10: Art. 1 ${ }^{\circ}$. São inelegíveis: I - para qualquer cargo: g) os que tiverem suas contas relativas ao exercício de cargos ou funções públicas rejeitadas por irregularidade insanável que configure ato doloso de improbidade administrativa, e por decisão irrecorrível do órgão competente, salvo se esta houver sido suspensa ou anulada pelo Poder Judiciário, para as eleições que se realizarem nos 8 (oito) anos seguintes, contados a partir da data da decisão, aplicando-se o disposto no inciso II do art. 71 da Constituição Federal, a todos os ordenadores de despesa, sem exclusão de mandatários que houverem agido nessa condição; (Redação dada pela Lei Complementar $n^{\circ} 135$, de 2010) (grifos nossos) BRASÍLIA (BR). Lei Complementar $\mathrm{n}^{\circ} 64$, de 18 de maio de 1990. Estabelece, de acordo com o art. 14, § $9^{\circ}$ da Constituição Federal, casos de inelegibilidade, prazos de cessação, e determina outras providências. Diário Oficial da União de 21 de maio de 1990.

${ }^{88}$ A ementa do referido acórdão é a seguinte: "ELEIÇÕES 2010. REGISTRO DE CANDIDATURA. AGRAVO REGIMENTAL EM RECURSO ORDINÁRIO. INELEGIBILIDADE. ÓRGÃO COMPETENTE. REJEIÇÃO DE CONTAS. PREFEITO. CÂMARA MUNICIPAL. DESPROVIMENTO. 1. Consoante precedentes desta Corte, a competência para o julgamento das contas de Prefeito é da Câmara Municipal, cabendo aos Tribunais de Contas a emissão de parecer prévio, inclusive, quando examinados atos de ordenação de despesas. 2. Agravo regimental desprovido". (Agravo Regimental no Recurso Ordinário no 4417-24.2010.6.15.000 - Classe 37 - João Pessoa - Paraíba, Rel. Min. Hamilton Carvalhido. "O Tribunal, por maioria, desproveu o agravo regimental, nos termos do voto do relator. Acórdão publicado na sessão de 09/11/10". Disponível em: <http://www.tse.gov.br/internet/jurisprudencia/inteiro_teor.htm>, acesso em 04 de ago. 2011.
} 
O que se verifica no caso em comento é que o Congresso Nacional, composto por representantes do povo, elaborou lei para tornar inelegível o ordenador da despesa que tivesse suas contas rejeitadas pelo Tribunal de Contas, incluído, nessa situação o Chefe do Executivo. O Poder Judiciário, no entanto, modificou o intuito da lei e excluiu da inelegibilidade o Chefe do Executivo, quando ele for ordenador da despesa, consoante anteriormente explicado.

A esta possibilidade de o Poder Judiciário interferir nas hipóteses de inelegibilidade delimitadas pela lei, que reflete a vontade popular, e modificá-la, sem que tenham os seus membros sido eleitos nas urnas para fazê-lo, chama-se "judicialização da política”, que pode degenerar e afetar negativamente a democracia vigente, pois, consoante assevera Karl Loewenstein "instalar um tribunal como árbitro supremo do processo do poder - e este é o núcleo da 'judicialização da política' - transformaria, em última análise, o sistema governamental em um domínio dos juízes ou em uma 'judiciocracia', ,89 (tradução nossa)

\subsection{O princípio da separação de Poderes no século XX: novas perspectivas de divisão do poder político}

Neste tópico, apresentamos doutrinas que visam a reformular a teoria da separação de Poderes de Montesquieu. Quer isto dizer que elas partem da teoria do mestre, porém, dão-lhe uma nova conotação.

A primeira, da lavra de Karl Loewenstein, defende que o controle do poder político deve ser estudado sob uma nova ótica: a dos detentores do poder. Estes não os órgãos - é que devem ser controlados. Já a segunda, visa a inserir o Tribunal de Contas em tal teoria. São as teses de Hamilton Fernando Castardo e Diogo de Figueiredo Moreira Neto. Ambos partem do fato de que a democracia requer a existência de outros polos de controle do poder, dentre os quais se encontra o Tribunal de Contas, como um “órgão autônomo” ou um “órgão constitucional de soberania”, respectivamente.

Analisemos cada uma delas.

\footnotetext{
89 "Instalar um tribunal como árbitro supremo del proceso del poder - y éste es el núcleo de la 'judicialización de la política' -, transformaria, em último término, el sistema gubernamental em um domínio de los jueces o em uma 'judiciocracia””. LOEWENSTEIN, Karl. Op. cit. p. 325.
} 


\subsubsection{A função de controle inserida no processo do poder: a proposta de Karl Loewenstein}

Um dos principais combatentes da teoria clássica de Montesquieu, no século XX, foi Karl Loewenstein.

Parte o autor da explicação de que o poder, quando não é controlado, é demoníaco e se transforma em tirania, em despotismo ou, como dizia Montesquieu, o poder irá corromper o poder. ${ }^{90}$

A fim de evitar este caráter demoníaco, é preciso controlar o exercício do poder, de modo que, em sua visão, não basta dividir o seu exercício entre três órgãos distintos, como dizia Montesquieu. É necessário impor limites e restrições aos detentores do poder. Há, dessa forma, para Karl Loewenstein, uma relação direta entre o controle do exercício do poder e os seus detentores.

Assevera o doutrinador, pois, que "limitar o poder político quer dizer limitar os detentores do poder" ${ }^{\prime 91}$ que, segundo defende, em um Estado constitucional são quatro: o Parlamento, o Governo, os Tribunais Judiciários e o eleitorado ${ }^{92}$.

Essa doutrina é baseada, então, em um Estado constitucional, porém, para comprovar sua tese, o autor compara-o ao seu oposto, o Estado autocrático ${ }^{93}$.

90 "El poder incontrolado es, por su propia naturaleza, malo. El poder encierra en sí mismo la semilla de su
propia degeneración. Esto quiere decir que cuando no está limitado, el poder se transforma en tiranía y em
arbitrario despotismo". Idem. p. 28 .
91 Karl Loewenstein explica que "limitar el poder político quiere decir limitar a los detentadores del poder".
Idem. p. 29.
92 Na parte geral de sua obra (p. 36), Karl Loewenstein não fala em eleitorado. Diz ele que um dos grupos de
detentores do poder são "los propios destinatarios del poder, que, al organizarse em los cuadros de los
partidos políticos, se elevan a la condición de un detentador del poder independiente participando
directamente en el proceso político a través de elecciones, procedimientos de referéndum e impacto de la
opinión pública en los otros órganos estatales". Na segunda parte de sua obra, no entanto, ao tratar dos
controles horizontais do poder político, divide o controle externo em quatro grupos: o controle externo do
Parlamento frente ao Governo; o do Governo frente ao Parlamento; o dos Tribunais frente ao Governo e ao
Parlamento e o do eleitorado frente ao Governo e ao Parlamento daí porque optamos por traduzir este
destinatário do poder como "eleitorado". Para detalhes, consultar: LOEWENSTEIN, Karl. Teoría de la
Constitución. Traducción y estudio sobre la obra por Alfredo Gallego Anabitarte. Barcelona: Editorial Ariel,
1976 . p. 36 e pp. $326-349$.
93 Na verdade, o autor quer comparar dois sistemas políticos: o constitucionalismo e a autocracia. Quanto a
esta última, explica ser ela caracterizada por um único detentor do poder, que é o déspota, uma assembleia,
um comitê, uma junta ou um partido. Neste sistema, o exercício do poder não está distribuído e sim
concentrado e tampouco se pode falar em controle do poder. Não há também, nenhum limite constitucional.
Na verdade, tais características em nada diferem da concentração do poder da época do absolutismo, já
estudada. O autor, na verdade, se utiliza deste sistema para explicar a novidade: que o poder político pode ser 
Acerca do Estado constitucional, assim o define Karl Loewenstein:

\begin{abstract}
"O Estado constitucional se fundamenta no princípio da distribuição do poder. A distribuição do poder existe quando vários e independentes detentores do poder ou órgãos estatais ${ }^{94}$ participam da formação da vontade estatal. As funções que lhes foram conferidas estão submetidas a um controle respectivo por meio dos outros detentores do poder. Pelo fato de estar distribuído, o exercício do poder está necessariamente controlado". ${ }^{95}$ (grifos e tradução nossos)
\end{abstract}

Em um Estado constitucional, portanto, repita-se: quando o exercício do poder político estiver distribuído entre os seus diversos detentores, ele estará também controlado. E mais. Para que haja distribuição do poder, é necessário que os detentores cooperem para a formação da vontade estatal.

Como se dá a cooperação entre os detentores do poder? Por meio dos controles horizontal e vertical. O primeiro caracteriza-se pelo controle interno (dentro da organização de cada detentor) e pelo controle externo ("entre diversos detentores do poder" ${ }^{96}$ ), configurando-se, assim, como controle externo, o exercido pelo Parlamento sobre o Governo; pelo Governo sobre o Parlamento; pelos Tribunais Judiciários sobre o Governo e o Parlamento e pelo eleitorado sobre o Governo e o Parlamento. O controle vertical $^{97}$, por seu turno, é aquele que se processa pela interação de todos os detentores do poder com a sociedade e se apresenta sob três formas: o federalismo, os direitos

controlado pelos seus detentores, o que constitui a finalidade de sua obra. Para detalhes, consultar: LOEWENSTEIN, Karl. Teoría de la Constitución. Traducción y estudio sobre la obra por Alfredo Gallego Anabitarte. Barcelona: Editorial Ariel, 1976. p. 51.

${ }_{94}$ Alertamos o leitor que usaremos esta passagem no Capítulo V, item 5.5 (A natureza da competência exercida pelo Tribunal de Contas e pela Câmara Municipal na aprovação das contas municipais), quando tratarmos da tese propriamente dita quando, então, o nosso interesse será referente à distribuição do poder político não aos detentores do poder (Governo, Parlamento, Tribunais Judiciários e eleitorado) e sim aos órgãos estatais, tal como referido nesta passagem. O objetivo é verificar, primeiro, se o Tribunal de Contas pode ser entendido como um órgão estatal e, depois, se o poder político também é a ele distribuído quando exerce suas competências constitucionais do artigo 71 da Constituição Federal de 1988, dentre as quais, a de elaborar o parecer prévio sobre as contas municipais que são julgadas pelo Poder Legislativo.

95 "El Estado constitucional se basa en el principio de la distribución del poder. La distribución del poder existe cuando varios e independientes detentadores del poder u órganos estatales participan en la formación de la voluntad estatal. Las funciones que les han sido asignadas están sometidas a un respectivo control a través de los otros detentadores del poder; como está distribuido, el ejercicio del poder político está necesariamente controlado". LOEWENSTEIN, Karl. Op. cit. p. 50.

${ }^{96}$ Sobre o controle externo, explica Karl Loewenstein que o quando "las instituciones de control operam (...) entre diversos detentadores del poder que cooperam em la gestión estatal, se les designa como controles interórganos". Idem. p. 232.

${ }^{97}$ Sobre o controle vertical, assevera Karl Loewenstein: "Bajo este concepto caen aquellos tipos o modos de acción e interacción que se producen dentro del cuadro de la dinámica política entre todos los detentadores del poder instituídos - parlamento, gobierno, tribunales y electorado - y la sociedad en su totalidad". Idem. p. 353. 
individuais e garantias constitucionais e o pluralismo. O controle vertical não é, no entanto, objeto de nosso estudo.

Ainda que tenhamos apresentado, até o momento, apenas linhas gerais a respeito da doutrina de Karl Loewenstein, é possível defender que toda sua teoria está fundamentada na ideia do controle.

$\mathrm{Ou}$, melhor dizendo, o controle é trazido para dentro do processo do poder. É este o entendimento de Pedro Carlos Bacelar de Vasconcelos, que ao estudar a obra do autor, conclui:

\footnotetext{
“(...) o controlo político, constitui uma 'função especial separada' (...). Que pretende, então, com esta insistência em qualificar o controlo como uma 'função' do Estado que, todavia, não cuida de articular com as restantes, nem por um critério orgânico-institucional, nem pela sua estrutura ou pelo seu conteúdo material? - Justamente, supomos, incluir o controlo no próprio 'processo do poder"' 98 (grifos nossos)
}

Pedro Carlos Bacelar de Vasconcelos explica, ainda, que a autocracia reaparece nos Estados constitucionais porque estes tentam neutralizar o poder apenas através do controle das suas instituições ("critério orgânico-institucional") - e não também de seus detentores. ${ }^{99}$ E continua:

\begin{abstract}
"Ora, se 'todas as funções estaduais são instrumentos para o exercício da direçção política', não será pela virtude intrínseca de uma qualquer arrumação, por mais engenhosa, que se controla o poder, mas apenas quando esteja garantida a sua distribuição por distintos titulares. Condenados os detentores do poder à cooperação, fica o exercício do poder político necessariamente controlado e o elemento 'controlo', do mesmo passo, 'inscrito' no 'processo do poder". ${ }^{100}$ (grifos nossos)
\end{abstract}

Concordamos em parte com o autor precitado. O controle do poder político integra mesmo o "processo do poder" na teoria de Karl Loewenstein. Toda sua obra, aliás, é baseada em controlar o poder político, o que se obtém pelos controles vertical e horizontal sobre os seus detentores. Mas isto não quer dizer, pensamos, que a teoria de Montesquieu - que traz o critério orgânico-institucional anteriormente citado -

\footnotetext{
${ }^{98}$ VASCONCELOS, Pedro Carlos Bacelar de. Teoria geral do controlo jurídico do poder público. Lisboa: Edições Cosmos, 1996. p. 89.

${ }^{99}$ Idem. Ibidem.

${ }^{100}$ Idem. Ibidem.
} 
deva ser desprezada ou não tenha servido para, também, controlar o poder. Sob o prisma desta teoria, o poder político foi controlado, tanto por meio da atribuição de funções típicas aos órgãos do poder, como através dos "checks and balances", em que pese não houvesse um controle sobre os destinatários do poder. A teoria clássica adequou-se à época em que foi escrita, mas serve de base até hoje para os Estados constitucionais que se formam, pelo menos no Ocidente.

Ademais, o que Karl Loewenstein fez foi revisitar a teoria da separação de Poderes, para construir a sua. Ele não desprezou a versão clássica, mas, é verdade, criticou-a.

É que, enquanto para Montesquieu a função típica é desempenhada por um Poder ${ }^{101}$, para Karl Loewenstein, cada uma das funções se concretiza pela participação de dois ou mais detentores ${ }^{102}$ do poder e é esta mecânica - de dois ou mais detentores terem participação na mesma função -, que resulta no controle do poder político.

\subsubsection{O Poder Legislativo e o controle político}

Com o controle inserido no "processo do poder", trata Karl Loewenstein de apresentar a sua teoria reformulada, partindo, também, de três funções, que são: "policy determination” (ou decisão política fundamental); "policy execution” (ou execução da decisão política); e "policy control” (ou controle político).

As decisões políticas são adotadas pelo constituinte originário e, em uma democracia, dizem respeito às resoluções mais importantes e que conduzem ao desenvolvimento presente e futuro da sociedade. Dentre tais decisões políticas, a fundamental (“policy determination”) consiste na escolha, pela Nação, do sistema político (monarquia constitucional ou república) e, dentro desse sistema, da forma específica de

\footnotetext{
${ }^{101}$ Karl Loewenstein critica a expressão "Poder" usada por Montesquieu. Para o autor, o que a teoria clássica quis foi distribuir e controlar o exercício do poder político através da distribuição de funções estatais a diferentes órgãos do Estado. Daí porque ele não fala em separação de Poderes e sim em separação de funções. Para detalhes, consultar: LOEWENSTEIN, Karl. Op. cit. p. 55.

${ }^{102} \mathrm{O}$ autor exemplifica seu entendimento com o Parlamentarismo explicando que em tal forma de governo, os membros do Parlamento formam o Governo. Nas palavras de Karl Loewenstein "um simple vistazo a la forma más corriente de gobierno, el parlamentarismo, hubiera podido convencer a los autores constitucionalies de que el poder legislativo y el ejecutivo no están separados ni personal ni funcionalmente. Los miembros del gobierno son miembros del parlamento; se há producido, pues, uma integración de estos poderes". Idem. Ibidem. p. 55.
} 
governo (parlamentarismo ou presidencialismo). A decisão política fundamental é executada pelo Governo, mas este necessita, obrigatoriamente, do Parlamento, na medida em que as decisões políticas somente se concretizam através da legislação. Então, $a$ decisão política é exercida conjuntamente pelo Governo (Poder Executivo) e pelo Parlamento, ao contrário do que pregava Montesquieu. E mais, tal função pode contar, posteriormente, com a participação do eleitorado, como função conformadora, isto é, com a participação deste aprovando a decisão política fundamental de modo direto (através de referendos) ou indireto (por meio das eleições).

A execução da decisão política fundamental ("policy execution”), por sua vez, está distribuída entre os diversos detentores do poder: o Parlamento, o Governo e os Tribunais Judiciários. O primeiro, porque a decisão política fundamental escolhida pelo povo é materializada em leis e códigos que serão, por sua vez, aplicados pelos segundos, que são as autoridades e funcionários do Governo. Aos Tribunais Judiciários, por seu turno, compete a execução da decisão política fundamental contida nas leis.

Quanto ao controle político ("policy control"), considerado o núcleo da "nova" Separação de Poderes, este é entendido como o mecanismo mais eficaz para o controle do poder político e requer que o poder seja distribuído entre todos os seus detentores: o Governo, o Parlamento e o eleitorado. Destaca Karl Loewenstein que o ponto central deste controle é a possibilidade de exigir a responsabilidade política. Ensina o autor precitado que:

\footnotetext{
"Existe responsabilidade política quando um determinado detentor do poder tem que prestar contas ao outro detentor do poder sobre o cumprimento da função que lhe foi conferida, por exemplo, o Governo ao Parlamento, o Parlamento ao Governo e, em última instância, ambos ao eleitorado". ${ }^{103}$ (tradução e grifos nossos)
}

\footnotetext{
${ }^{103}$ De acordo com Karl Loewenstein, “existe responsabilidad política cuando um determinado detentador del poder tiene que dar cuenta a outro detentador del poder sobre el cumplimiento de la función que le há sido asignada, por ejemplo, el gobierno al parlamento, el parlamento al gobierno y, em último término, ambos al electorado". Idem. p. 70. Advertimos o leitor que esta passagem será utilizada novamente, quando estudarmos se o Tribunal de Contas também exerce o controle político quando elabora o parecer prévio (Capítulo V, item 5.4 - Há controle político quando o Tribunal de Contas elabora o parecer prévio apreciando as contas de governo apresentadas pelo Prefeito?)
} 
Isto quer dizer que a responsabilidade política ocorre quando um detentor do poder conclui que o outro desempenhou mal a sua função. A consequência é a responsabilização deste mau executor, de modo a restabelecer o equilíbrio, fruto da cooperação entre os detentores do poder.

Assim, em um sistema parlamentar, que é o estudado pelo autor, o voto de desconfiança do Parlamento frente ao Governo; a possibilidade de o Governo dissolver o Parlamento; e, ainda, ambos - parlamentares e membros do Governo - terem os seus mandatos confirmados ou rechaçados pelos eleitores nas urnas, são exemplos ${ }^{104} \mathrm{de}$ responsabilidade política.

No cenário pátrio, que adota o sistema presidencial e, somente no que concerne ao nosso trabalho, o princípio da responsabilidade política, fruto do controle político, faz-se presente na medida em que as contas do Chefe do Executivo (detentor do poder) são julgadas pelo Poder Legislativo (outro detentor do poder). A diferença aqui - relacionada à tese que desejamos comprovar - é que a apresentação delas não se faz diretamente ao Poder Legislativo e sim ao Tribunal de Contas, um órgão estatal, que elabora um parecer prévio e o encaminha ao Poder Legislativo servindo, tal documento, como embasamento para a manifestação deste. Se o julgamento for desfavorável, isto é, se as contas do Chefe do Executivo forem rejeitadas pelo Poder Legislativo, o primeiro sofrerá sanções, dentre as quais a inelegibilidade por oito anos.

O Chefe do Executivo também presta contas ao eleitorado (mais um detentor do poder), que poderá ou não reelegê-lo na época das eleições. Daí porque Karl Loewenstein conclui: “a responsabilidade política se converteu na técnica mais eficaz de controlar o detentor do poder". ${ }^{105}$

Discorrendo sobre a "policy determination", a "policy execution” $\mathrm{e}$ a "policy control” em cenário pátrio, Manoel Gonçalves Ferreira Filho assevera: "a primeira consiste em escolher as políticas que devem ser adotadas. A segunda, em implementá-las; a última, em chamar à responsabilidade os que escolhem as políticas (na perspectiva do 'responsible government') e os que a executam". ${ }^{106}$

\footnotetext{
104 Tais exemplos estão explicados em LOEWENSTEIN, Karl. Op. cit. p. 71.

105 "La responsabilidad política se há convertido en la técnica más eficaz para controlar al detentador del poder". Idem. Ibidem. p. 71.

${ }^{106}$ FERREIRA FILHO, Manoel Gonçalves. Princípios... Op. cit. p. 266.
} 
E continua o mesmo autor:

"Esta visão dinâmica pode inspirar uma revisão de conceitos sobre a divisão, dita funcional, do poder. O Governo deve desempenhar a 'policy determination', orientado, na democracia, pela decisão popular. A Câmara, ou as câmaras, o controle dessa política, tanto na sua formulação quanto na sua execução ('policy control'). E, como um aspecto da formulação é a lei, controlando-a no seu conteúdo. $O$ Judiciário fica com o controle no aspecto jurídico, ou seja, com a fiscalização do cumprimento desse direito e a concretização deste relativamente ao indivíduo e seus direitos fundamentais". ${ }^{107}$ (grifos nossos)

O que se extrai das citações anteriores é que, consoante Manoel Gonçalves Ferreira Filho, o Poder Legislativo ganha prestígio, já que a ele é conferido o controle político. Tal se dá porque a ele compete controlar a escolha da decisão política fundamental ("policy determination”), feita pelo Poder Executivo e a sua execução ("policy execution”), uma vez que a decisão política fundamental só pode ser executada através de lei por ele elaborada.

Há que se ressaltar, ainda, também na lição de Karl Loewenstein, que o controle político a cargo do Poder Legislativo constitui, no sistema parlamentar, a forma mais importante de controle externo que o Parlamento ${ }^{108}$ exerce sobre o Governo. Nesse sentido, assevera o mestre:

"O controle externo mais importante que possui o Parlamento frente ao Governo, e que existe em todas as formas de democracia constitucional, é rejeitar uma proposta legislativa apoiada direta ou indiretamente pelo Governo e sua ação equivalente, isto é, negar um pedido de crédito solicitado pelo Governo"” ${ }^{109}$ (grifos e tradução nossos)

Da mesma forma, no sistema presidencial o controle político funciona como um controle externo frente ao Poder Executivo. É o que preleciona o autor:

\footnotetext{
${ }^{107}$ Idem. Ibidem.

${ }^{108}$ Para Karl Loewenstein o controle externo do Parlamento sobre o Governo decorre: 1) da independência funcional do Parlamento e; 2) dos mecanismos de controle que ele exerce sobre o Governo. Inserem-se neste último grupo: a) a nomeação do Governo; b) os controles políticos de rotina; c) a queda do Governo através do voto de desconfiança e; 4) a destituição do Presidente ou do Chefe de Estado nos casos de impeachment. Para detalhes, consultar: LOEWENSTEIN, Karl. Op. cit. p. 267.

109 "El control interórgano más importante de que está dotado el parlamento frente al gobierno, y que existe en todas las formas de democracia constitucional, es rechazar una propuesta legislativa apoyada directa o indirectamente por el gobierno, y su acción equivalente, esto es, negar una autorización monetaria pedida por el gobierno". Idem. p. 261.
} 
"Também no sistema presidencial, a rejeição a uma proposta legislativa funciona como o controle externo mais eficaz frente ao Presidente, embora este seja inamovível durante o mandato: o Presidente terá que abandonar a medida referida ou mudá-la, de acordo com os desejos do Congresso". ${ }^{110}$ (tradução e grifos nossos)

Ainda no âmbito do nosso tema, o controle político que o Poder Legislativo exerce se faz presente na discussão anual do orçamento, que culmina com a aprovação da lei orçamentária e de suas emendas, apta esta a direcionar a atuação do Chefe do Poder Executivo na realização das políticas públicas que objetivam o bem-estar do povo. Também se observa tal controle, consoante anteriormente explicado, no julgamento das contas públicas.

\subsubsection{E o Tribunal de Contas?}

A teoria da separação de Poderes de Montesquieu não abordou o Tribunal de Contas. Não obstante, em cenário pátrio, alguns autores se preocuparam em inserir tal órgão na sistemática do controle e, para tanto, cuidaram, igualmente, de atualizar a referida teoria da separação de Poderes.

Trazemos à colação as linhas gerais do posicionamento de apenas dois destes doutrinadores, uma vez que as especificidades do órgão serão tratadas nos Capítulos III e IV. A opção por estes dois decorre do papel de destaque que conferem ao Tribunal de Contas. São eles: Hamilton Fernando Castardo e Diogo de Figueiredo Moreira Neto. O primeiro o considera o Tribunal como um órgão autônomo e, o segundo, como um órgão constitucional de soberania.

\section{Hamilton Fernando Castardo defende existirem, no Estado} Democrático de Direito, outras funções, não tratadas por Montesquieu, e relacionadas ao controle do exercício do poder pelo povo, as quais foram conferidas a novos órgãos, chamados de órgãos autônomos, dentre os quais se encontram o Tribunal de Contas e as agências reguladoras. Nas palavras do autor:

\footnotetext{
110 “También en el presidencialismo, el rechazar una propuesta legislativa funciona como el control interórgano más eficaz frente al presidente, aunque éste sea inamovible durante la duración de su cargo: el presidente tendrá que abandonar dicha medida o cambiarla según los deseos del Congreso”. Idem. pp. 261262.
} 
"Contemporaneamente, a idéia da tripartição de poderes não é suficiente para o controle democrático do exercício do poder, induzindo a superála por meio de uma organização com órgãos autônomos, que contenham mais funções do que as preconizadas por Montesquieu, como o Tribunal de Contas. O órgão de contas não se coaduna em se localizar em um dos três poderes, que forçosamente seria inadequado e artificial". ${ }^{111}$ (grifos nossos)

Segundo o autor, são o Estado Democrático de Direito e a necessidade de seu controle que tornam indispensável a revisão da teoria clássica, em razão do surgimento de novos órgãos com funções distintas das concernentes aos três Poderes. Mas o doutrinador não elimina a existência destes Poderes. Convivem juntos - os Poderes Executivo, Legislativo e Judiciário - com os "órgãos autônomos", estes com funções que lhes foram constitucionalmente asseguradas.

O Tribunal de Contas, como um destes órgãos, configura-se como um órgão de controle do Poder. Assevera o autor, no entanto, que a Constituição de 1988 "instrumentalizou-o como se fosse [um Poder], pois os constituintes perceberam a exigência atual: a garantia dos processos democráticos". 112

Na mesma linha de raciocínio, Diogo de Figueiredo Moreira Neto explica que, nas democracias contemporâneas do pós Segunda Guerra Mundial, as Constituições Italiana (1948), a Alemã (1949) e a Portuguesa (1976) conferiram autonomia constitucional às Cortes de Contas, inserindo-as como "órgãos constitucionais de soberania" e que o Brasil (1988), em que pese não tenha seguido a mesma sistemática, garantiu-lhes autonomia, porque lhes atribui as mesmas prerrogativas do Poder Judiciário (artigo 73 in fine combinado com o artigo 96), "de modo que, de maneira enfática, no elenco de suas atribuições constitucionalmente dispostas, satisfaz concomitantemente a todos os critérios que igualmente o identificam e o distinguem como uma das estruturas políticas de soberania, no desempenho de diversas funções de proteção de direitos fundamentais de sede constitucional". ${ }^{113}$ (grifos nossos) Daí porque ser o Tribunal de Contas formalmente um órgão constitucional.

${ }^{111}$ CASTARDO, Hamilton Fernando. O Tribunal de Contas no ordenamento jurídico brasileiro. Campinas, SP: Millenium, 2007. p. 29.

112 Idem. Ibidem.

${ }^{113}$ MOREIRA NETO, Diogo de Figueiredo. O Parlamento e a sociedade como destinatários do trabalho dos Tribunais de Contas. In: SOUSA, Alfredo José de et al. O novo Tribunal de Contas: órgão protetor dos direitos fundamentais. $3^{\mathrm{a}}$ ed. rev. e ampl. Belo Horizonte: Fórum, 2005. p. 104. 
Aduz, ainda, que o Tribunal de Contas é órgão também materialmente constitucional e o faz utilizando a classificação de Enrico Spagna Mussa, pela qual o órgão: a) possui doze funções constitucionais (artigo 71 e $\S 2^{\circ}$ ) que se diferem das de outros órgãos estatais; b) é órgão constitucional essencial, porque exerce funções políticas, "assim entendidas as que são expressões imediatas da soberania (art. 73, I c/c art. 70 , caput)"114 e; c) por ser o responsável pela matéria orçamentária, caracteriza-se como “órgão garantidor dos valores político-constitucionais do Estado Democrático de Direito" 115 à medida que suas funções são vitais para o funcionamento dos princípios republicano e democrático ${ }^{116}$.

Considera também o autor que o Estado Democrático de Direito abre caminho para o aparecimento de novos órgãos, independentes, que não se confundem com os três Poderes e que têm guarida constitucional sendo, assim, dotados de autonomia para o exercício de suas funções, como o são o Tribunal de Contas, as funções essenciais à justiça (o Ministério Público, a Advocacia Geral da União, a Ordem dos Advogados do Brasil e a Defensoria Pública) e os congêneres no âmbito dos Estados-membros, do Distrito Federal e dos Municípios.

\subsection{A responsabilidade do detentor do poder}

O poder é responsável. Esta afirmação só é tida como verdadeira no Estado de Direito. É que neste, a Constituição e o instituto da responsabilidade são conceitos interligados. ${ }^{117}$ Antes, no Estado absoluto, o príncipe era irresponsável e, por isso, não respondia à sociedade pelos atos praticados. Sobre a irresponsabilidade, característica do Estado Aboluto, preleciona Cláudio Lembo:

\footnotetext{
${ }^{114}$ Idem. Ibidem.

${ }^{115}$ MOREIRA NETO, Diogo de Figueiredo. O Parlamento e a sociedade como destinatários do trabalho dos Tribunais de Contas. In: SOUSA, Alfredo José de et al. O novo Tribunal de Contas: órgão protetor dos direitos fundamentais. $3^{\mathrm{a}}$ ed. rev. e ampl. Belo Horizonte: Fórum, 2005. p. 105.

116 Para detalhes, consultar: MOREIRA NETO, Diogo de Figueiredo. O Parlamento e a sociedade como destinatários do trabalho dos Tribunais de Contas. In: SOUSA, Alfredo José de et al. O novo Tribunal de Contas: órgão protetor dos direitos fundamentais. $3^{\mathrm{a}}$ ed. rev. e ampl. Belo Horizonte: Fórum, 2005. pp. 104105.

${ }^{117}$ Pedro Lomba afirma que "a responsabilidade política é um conceito constitucional. As funções da responsabilidade política são também as funções da constituição". LOMBA, Pedro. Teoria da responsabilidade política. Coimbra: Coimbra Editora, 2008. p. 22. Mais adiante, o autor ressalta: "Além de ser um conceito constitucional e de contribuir, nesse sentido, para a moderação do poder político, podemos dizer que a responsabilidade política é a única forma de responsabilidade pública ligada geneticamente ao advento do constitucionalismo". Idem. p. 24.
} 
"Durante séculos, o Estado foi considerado irresponsável. Exatamente isso. A partir do princípio da irresponsabilidade do Estado, os agentes públicos não respondiam pelos atos praticados no exercício de suas atividades funcionais.

A teoria da irresponsabilidade do Estado confundia-se com o princípio do direito divino dos reis, próprio dos regimes absolutistas, estampado em múltiplas constituições, inclusive na brasileira de 1824". ${ }^{118}$

Em cenário oposto encontra-se o Estado de Direito. Aliás, sobre ele já analisamos que a limitação do poder do governante só foi possível graças ao movimento do constitucionalismo, que culminou com a promulgação de Constituições escritas e o surgimento do Estado de Direito, cujas características marcantes são o estabelecimento do princípio da separação de Poderes e a proteção dos direitos fundamentais do homem.

Trata-se, neste tópico, de examinar a responsabilidade do detentor do poder identificando a "conduta do agente político"119 e fazendo-o responder por seus atos diante da sociedade. Isto é, a responsabilidade acaba se tornando, também, uma forma de limitação do poder, na medida em que obriga o governante a respeitar a Constituição e as normas jurídicas e obriga-o a responder à sociedade pelos ilícitos praticados. Como bem assevera Pedro Lomba, "sendo certo que a limitação do poder implica a sua responsabilização e que, por isso, um poder constitucional é um poder responsável, fica por esclarecer de que forma, e sob que processos, é que essa responsabilização se produz". ${ }^{120} \mathrm{Na}$ sequência, o autor explica existirem três formas de responsabilidade: "a responsabilidade civil do Estado por danos causados no âmbito das suas funções; a responsabilidade criminal dos titulares de cargos políticos; e a responsabilidade política desses titulares". ${ }^{121}$ Nosso estudo restringir-se-á a analisar as características gerais desta última, relacionando-a à representação política e ao dever de o detentor do poder prestar contas.

\footnotetext{
${ }^{118}$ LEMBO, Cláudio. Visões... Op. cit. p. 28.

${ }^{119}$ Pedro Lomba afirma: "As constituições delimitam a ordem política no espaço e no tempo, identificando os sujeitos políticos e os respectivos poderes, estabelecendo os direitos dos cidadãos, separando tendencialmente o político do não-político. Em resumo, a função ordenadora das constituições também serve para discriminar um estado - um espaço público constitucional - em que a conduta dos agentes políticos não é neutra ou inócua, assumindo relevância jurídica e criando-lhes obrigações particulares perante outros agentes políticos e perante os cidadãos". Idem. p. 23.

${ }^{120}$ Idem. Ibidem.

${ }^{121}$ Idem. Ibidem.
} 


\subsubsection{A responsabilidade política}

Estado absoluto e Estado de Direito apresentam diferenças também no que concerne ao instituto da responsabilidade do poder.

Consoante analisamos, o déspota era irresponsável e isto se dava porque era ele considerado como filho de Deus na terra. Seu poder político tinha, portanto, origem divina e, enquanto esta situação permaneceu, nenhum de seus atos podia ser julgado pela justiça dos homens. No Estado de Direito, por seu turno e, especialmente com o desenvolvimento da democracia, o governante passa a ser o representante do povo. É eleito pelo povo e a ele deve responder. Desenvolve-se o fenômeno da representação política e, com ele, a tese da responsabilidade do poder. Sobre o tema, bem assevera Pedro Lomba:

"Entramos agora num tema delicado: a relação entre a responsabilidade
política e a representação política. A dúvida imediata passa por saber se a
actividade representativa traduz uma das obrigações possíveis de
responsabilidade política? De facto, alguns dos potenciais sentidos de
responsabilidade política - representação, responsividade, obrigação
de prestar contas (accountability) - são indissociáveis e, em certa
medida, coincidentes". ${ }^{22}$ (grifos nossos)

Como aduziu o autor, a resposta é positiva. Realmente existe uma relação entre representatividade e responsabilidade do poder. Sobre ela, explica Pedro Lomba:

\footnotetext{
“o princípio representativo exige, em primeiro lugar, que o poder dos representantes seja consentido previamente pelos representados através de eleições ou através de outras formas de legitimação democrática. Em segundo lugar, a representação obriga a que os representantes se mantenham, continuamente, fiéis aos representados. A vontade daqueles que exercem o poder, sendo uma vontade formalmente separada da vontade dos representados, não pode, todavia, ser desligada destes últimos. Para garantir que a representação política não significa a criação de uma entidade irresponsável mas, pelo contrário, de um poder normativamente limitado, transparente e revogável, o esquema representativo obriga os representantes a estarem disponíveis para
}

${ }^{122}$ Idem. p. 76. 
explicar e justificar cada uma das suas decisões e, no limite, para suportar as suas consequências". ${ }^{123}$

Há responsabilidade política, portanto, quando o representante não atua de acordo com a vontade dos governados que o elegeram.

De outra parte, a responsabilidade política também se associa com o dever de prestar contas. É que os governantes são eleitos por vontade do povo e devem a ele prestar contas de suas ações. No que tange ao nosso tema - o controle das contas municipais - é preciso consignar que o governante precisa utilizar dinheiro público em prol do bem-estar coletivo. O representante utiliza, assim, recurso público que não lhe pertence, pois a titularidade do poder é do povo. Por consequência, tem ele o dever de prestar-lhe contas (accountability) ${ }^{124}$ e, se não o fizer ou se o fizer de maneira insatisfatória, incide sobre ele a responsabilidade política, a que todo representante está submetido. Também aqui, preciosa a lição de Pedro Lomba: "se obrigarmos aqueles que governam a prestarem contas do que fazem aos representados, isso melhorará a própria actividade de representação". ${ }^{25}$

Verifica-se, ademais, que a forma mais comum de o representante prestar contas ao povo é através das eleições. Este sistema pode não ser muito eficaz, pelo menos nos países presidencialistas como o Brasil, já que as eleições para Presidente, Governadores e Prefeitos ocorrem de quatro em quatro anos. O povo precisa, então, esperar quatro anos para, indiretamente, ou seja, através das urnas, exigir a responsabilidade política daquele que utilizou mal o dinheiro público. Daí porque Pedro Lomba disserta:

"Também aqui se afirma que as eleições constituem o momento certo
para efectivar a prestação de contas. No entanto, creio que podemos
conceber a obrigação de prestar contas como uma obrigação contínua e
muito mais ampla do que a accountability eleitoral. O dever de
prestação de contas será melhor compreendido se for reportado a

${ }^{123}$ Idem. p. 78.

${ }^{124}$ Pedro Lomba explica que a doutrina chama de accountability a obrigação de prestar contas. Explana que "dever de prestar contas é uma tradição necessariamente imperfeita de accountability mas permite-nos descobrir uma nova cadeia de significado entre a representação e a responsabilidade política". Mais para frente, continua o autor: "A responsabilidade política concorre com a obrigação de prestar contas (accountability), mas também a própria obrigação de prestar contas co-existe com outros termos - por exemplo, respondibilidade (answerability) - ou com outras dimensões mais concludentes do conceito de responsabilidade - a obrigação de suportar as consequências legais dos seus actos (liability)”. Idem. p. 82. ${ }^{125}$ Idem. p. 81. 
determinadas acções, num momento imediatamente posterior à sua prática. Convém frisar este aspecto, que não é, segundo creio, sublinhado com clareza por Pitkin: o que diferencia as eleições da obrigação de prestar contas é que as primeiras estão, em regra, temporalmente afastadas dos actos praticados pelos agentes políticos, enquanto as segundas ocorrem em momento imediatamente subsequente àqueles actos". ${ }^{26}$

Dentre estas "determinadas ações", executadas em um "momento imediatamente posterior à sua prática" podem ser consideradas a fiscalização dos atos do Chefe do Poder Executivo municipal pelo Poder Legislativo e, também, pelo Tribunal de Contas. Há, portanto, responsabilidade política quando a Câmara Municipal julga irregulares as contas do Prefeito, embasado no parecer prévio elaborado pelo Tribunal de Contas e quando este último julga as contas dos demais administradores públicos, gerando, em ambos os casos, a inelegibilidade do gestor, por oito anos.

Há que se ressaltar, ainda, que o artigo $9^{\circ}, 2^{127}$, da Lei $n^{\circ} 1.079$, de 10 de abril de 1950 estabelece que a não prestação de contas pelo Presidente da República ao Congresso Nacional, no prazo de sessenta dias após a abertura da sessão legislativa, contas estas referentes ao exercício anterior constitui ato de improbidade administrativa configurando-se, assim, como um crime de responsabilidade.

Após o estudo do poder, do princípio da separação de Poderes, com suas funções típicas, da inserção do controle político no "processo do poder", que resulta no princípio da responsabilidade política, no sentido de que um detentor do poder deve prestar contas ao outro detentor e no ordenamento pátrio, da inclusão do Tribunal de Contas como órgão autônomo ou órgão constitucional de soberania, com competências próprias e relevantes relativas à matéria orçamentária e relacionadas aos princípios democrático e republicano, tratamos, no Capítulo II, do dever de prestar contas e dos sistemas de controle existentes no ordenamento estrangeiro.

\footnotetext{
${ }^{126}$ Idem. p. 87.

127 “Art. $9^{\circ}$ São crimes de responsabilidade contra a probidade na administração: $\mathbf{2}$ - não prestar ao Congresso Nacional dentro de sessenta dias após a abertura da sessão legislativa, as contas relativas ao exercício anterior". BRASÍLIA (BR). Lei $\mathrm{n}^{\mathrm{o}} 1.079$, de 10 de abril de 1950. Disponível em: < http://www.planalto.gov.br/ccivil_03/leis/L1079consol.htm>, acesso em 06 de jan. 2012.
} 


\section{CAPÍtulo II: O DEVER DE PRESTAR CONTAS E O CONTROLE DO PODER}

A prestação de contas e o controle do poder político estão intimamente relacionados. Na verdade, para se entender o controle do poder político e seu objetivo é necessário, primeiramente, tecer algumas considerações sobre a prestação de contas, posto que é graças a ela que o gestor público responde à sociedade pelo bom ou mau uso do dinheiro público, nascendo, daí, a sua responsabilidade.

Este Capítulo é, pois, dedicado à prestação de contas pelo gestor público e, em seguida, às formas como se processa o controle do poder, passando, ademais, pelos modelos tradicionais de Tribunais de Contas existentes: o italiano, o francês, o belga e o português. Este último será estudado graças às similitudes com o sistema brasileiro elaboração de parecer prévio e remessa à Assembleia da República portuguesa - mas, também, pela suas diferenças: é que a Corte de Contas portuguesa integra o Poder Judiciário, o que não ocorre no Brasil.

De imediato, é preciso salientar que não é somente o gestor público que deve prestar contas, mas sim qualquer pessoa física ou jurídica, pública ou privada que utilize dinheiro público. Para incidir na responsabilidade pela prestação de contas, necessário que a pessoa esteja na posse de dinheiro público, que não lhe pertence, e que, no Brasil, pratique uma das ações referidas no parágrafo único do artigo $70^{128}$ da Constituição Federal.

Mas, quem são os gestores públicos? São os agentes políticos ou os funcionários públicos que administram o bem - dinheiro público - pertencente ao povo. São, ainda, nos dizeres de Afonso Gomes Aguiar e Márcio Paiva de Aguiar, com os quais concordamos, os "intermediários que são legalmente habilitados para essa função" "129, e

\footnotetext{
${ }^{128}$ O parágrafo único do artigo 70 dispõe que "prestará contas qualquer pessoa física ou jurídica, pública ou privada, que utilize, arrecade, guarde, gerencie ou administre dinheiros, bens e valores públicos ou pelos quais a União responda, ou que, em nome desta, assuma obrigações de natureza pecuniária". BRASIL. Constituição (1988). Constituição da República Federativa do Brasil: promulgada em 5 de outubro de 1988: atualizada até a Emenda Constitucional n $n^{\circ}$ 67, de 22-12-2010. 45 ed. ampl. São Paulo: Saraiva, 2011. p. 69.

${ }^{129}$ AGUIAR, Afonso Gomes; AGUIAR, Márcio Paiva de. O Tribunal de Contas na ordem constitucional. $2^{\mathrm{a}}$ ed. Belo Horizonte: Fórum, 2008. pp. 13-14.
} 
que, "enquanto administradores de patrimônio e de recursos de terceiros, têm sua atuação por estes [o povo] controlada". 130

Cabe, aqui, uma advertência: nosso trabalho estudará tão somente o uso do dinheiro público pelo gestor público quando este gestor for o Prefeito, enquanto Chefe do Executivo municipal. Porém, para que possamos diferenciar sua responsabilidade na prestação de contas será imprescindível, em caráter subsidiário, cuidarmos da prestação de contas pelos demais administradores (os demais agentes políticos como, por exemplo, o Secretário de Estado ou, também a título de exemplo, o responsável pelo adiantamento bancário, que recebe dinheiro para comprar cortinas para a sua escola).

Esta diferenciação de tratamento se deve ao fato de que os gestores públicos, com exceção do Chefe do Executivo municipal, quando utilizam recursos públicos subsumem-se ao disposto no inciso II do artigo 71 da Constituição Federal e têm suas contas julgadas ${ }^{131}$ pelo Tribunal de Contas. O Prefeito, diferentemente, tem as contas de governo apreciadas $^{132}$ pelo Tribunal de Contas, mediante a elaboração de um parecer prévio e julgadas ${ }^{133}$ pelo Poder Legislativo, de acordo com o disposto no inciso I do artigo 71, combinado com o inciso IX do artigo 49 da Lei Maior. E mais. O parecer prévio emitido pelo Tribunal de Contas, em âmbito municipal, para ser derrubado na Câmara dos Vereadores, necessita de, pelo menos, dois terços dos votos dos parlamentares, consoante artigo 31, $\S 2^{{ }^{134}}$, da Lei Maior.

\footnotetext{
${ }^{130}$ Idem. p. 14.

131 “Art. 71. O controle externo, a cargo do Congresso Nacional, será exercido com o auxílio do Tribunal de Contas da União, ao qual compete: II - julgar as contas dos administradores e demais responsáveis pelos dinheiros, bens e valores públicos da administração direta e indireta, incluídas as fundações e sociedades instituídas e mantidas pelo Poder Público federal, e as contas daqueles que derem causa a perda, extravio ou outra irregularidade de que resulte prejuízo ao erário público". (grifos nossos). BRASIL. Constituição (1988). Constituição da República Federativa do Brasil: promulgada em 5 de outubro de 1988: atualizada até a Emenda Constitucional no 67, de 22-12-2010. 45ª ed. ampl. São Paulo: Saraiva, 2011. p. 70.

${ }^{132}$ Art. 71. O controle externo, a cargo do Congresso Nacional, será exercido com o auxílio do Tribunal de Contas da União, ao qual compete: I - apreciar as contas prestadas anualmente pelo Presidente da República, mediante parecer prévio que deverá ser elaborado em sessenta dias a contar de seu recebimento". BRASIL. Constituição (1988). Constituição da República Federativa do Brasil: promulgada em 5 de outubro de 1988: atualizada até a Emenda Constitucional no 67, de 22-12-2010. 45 a ed. ampl. São Paulo: Saraiva, 2011. p. 69.

133 “Art. 49. É da competência exclusiva do Congresso Nacional: IX - julgar anualmente as contas prestadas pelo Presidente da República e (...)".BRASIL. Constituição (1988). Constituição da República Federativa do Brasil: promulgada em 5 de outubro de 1988: atualizada até a Emenda Constitucional n ${ }^{\circ}$ 67, de 22-12-2010. $45^{\mathrm{a}}$ ed. ampl. São Paulo: Saraiva, 2011. pp. 56-57.

134 “Art. 31. (...). § $2^{\circ}$. O parecer prévio, emitido pelo órgão competente sobre as contas que o Prefeito deve anualmente prestar, só deixará de prevalecer por decisão de dois terços dos membros da Câmara Municipal". (grifos nossos) BRASIL. Constituição (1988). Constituição da República Federativa do Brasil:
} 
Feitas estas considerações, ressaltamos que este Capítulo é dedicado à prestação de contas porque o seu sujeito é o gestor público que, em um regime republicano e democrático, como o nosso, não pode se furtar de cumprir o dever constitucional de apresentar ao povo um contínuo balanço de suas atividades, responsabilizando-se por elas, quer política e administrativamente, quer civil ou penalmente, quer, ainda, em se tratando do Prefeito, enquanto Chefe do Executivo municipal, submetendo-se ao julgamento dos eleitores nas urnas, sendo ou não reeleito para os cargos públicos a que concorrer. Também nos preocupamos, neste Capítulo, com o controle propriamente dito, isto é, com seus diversos significados e com os sistemas existentes no mundo.

Tratemos, inicialmente, de estudar como surgiu este dever de prestar contas.

\subsection{Evolução histórica do dever de prestar contas}

O dever de prestar contas está enraizado na cultura dos povos. Existe, embora com outros contornos, desde os primórdios da Humanidade.

O mundo antigo já conhecia o sistema de prestação de contas. Tanto é assim que o primeiro documento a respeito é contábil, tem dois mil e seiscentos anos e está redigido em escrita cuneiforme. ${ }^{135}$ Também a democracia ateniense e a antiga cidade de Roma apresentavam sistemas de prestação de contas. Destes, destaca-se o modelo Romano, em que:

“(...) os magistrados romanos, que assumiam tais funções temporariamente, deviam prestar contas perante as assembléias de cidadãos ou diante do Senado, conforme o caso, antes de deixarem seus respectivos cargos (exercidos graciosamente) para retornarem à situação de simples cidadãos". ${ }^{136}$

Observa-se, já nesta época, a importância do instituto da prestação de contas: antes de retornar à condição de "simples cidadão", o magistrado tinha o dever

promulgada em 5 de outubro de 1988: atualizada até a Emenda Constitucional no 67, de 22-12-2010. $45^{\mathrm{a}}$ ed. ampl. São Paulo: Saraiva, 2011. p. 40.

${ }^{135}$ CHAVES, Francisco Eduardo Carrilo. Controle externo da gestão pública: a fiscalização pelo Legislativo e pelos Tribunais de Contas. Niterói: Impetus, 2007. p. 6.

${ }^{136}$ Idem. p. 7. 
de prestar contas de suas atividades e o fazia aos cidadãos ou ao Senado. Trata-se, pois, já naquela época, de um verdadeiro controle externo exercido pelos cidadãos e pelo Senado sobre a atividade dos Magistrados.

O marco inicial do dever de prestar contas, no entanto, encontra-se no Estado moderno. A Declaração Universal de Direitos do Homem e do Cidadão, de 1789, fruto da Revolução Francesa e que iria embasar a Constituição norte-americana, pregava, em seu artigo 15 que "a sociedade tem o direito de pedir conta a todo agente público de sua administração" "137. Este artigo é característico do Estado de Direito, que se subordina à lei, não se autorizando aos detentores do poder o uso indiscriminado da verba pública. O Estado de Direito exige, portanto, que quem movimente dinheiro público preste contas à coletividade.

É no Estado Democrático de Direito que o dever de prestar contas assume sua maior importância. E isto porque, com o desenvolvimento da democracia, por um lado confere-se ao povo a titularidade do poder - o que inclui os gastos públicos - e, de outro, porque se exige do gestor público, isto é, no caso do nosso trabalho, do Prefeito que usa o dinheiro público - que os seus atos sejam dotados de transparência. Significa que o Prefeito deve demonstrar ao povo, enquanto detentor do poder - do qual ele é apenas representante -, como o dinheiro público foi gasto para que, então, possa ser responsabilizado pelo bom ou mau uso do recurso, o que se faz, inclusive, através das urnas, com a reeleição ou não do Prefeito para os cargos públicos. Verifica-se, então, que a democracia controla as contas porque quem exerce o poder deve prestar contas de seus atos. Mais do que isso, a democracia estabelece o vínculo entre a representatividade do poder, a prestação de contas e a responsabilização política pelo uso do dinheiro público.

Ademais, o dever de prestar contas é reflexo de um regime republicano, na medida em que o detentor do poder torna-se mero administrador da res publica, cujo comando pertence ao povo (titular do poder). E quem administra recursos alheios tem o dever de prestar contas. Como bem assevera Augusto Sherman Cavalcanti, é

137 Declaração Universal de Direitos do Homem e do Cidadão de 1789. Disponível em: < http://www.direitoshumanos.usp.br/index.php/Documentos-anteriores-à-criação-da-Sociedade-das-Naçõesaté-1919/declaracao-de-direitos-do-homem-e-do-cidadao-1789.html>, acesso em 05 de jan. 2012. 
na república que nasce o “(...) dever de prestar contas, vez que quem geria não era dono, mas apenas administrador desses recursos". ${ }^{138}$

Uma vez verificada a evolução histórica da prestação de contas, analisaremos, a seguir, as consequências dela decorrentes, consubstanciadas no controle do poder. Isto porque o poder limitado precisa ser controlado e, no que tange aos recursos públicos, tal controle se materializa pela prestação de contas do detentor do poder.

\title{
2.2. O conceito de controle do poder
}

Não existe controle sem poder. Mais. Não existe controle sem poder repartido, dividido, limitado. Daí porque a teoria da separação de Poderes atua como o fundamento necessário para que se possa falar em controle do poder político.

Já tive a oportunidade de me manifestar sobre o tema e naquela ocasião asseverei:

\begin{abstract}
"Controle e poder tinham significados antagônicos no Absolutismo, vez que a concentração do poder nas mãos do rei significava a total ausência do controle. Este último somente começa a ganhar destaque com o nascimento do Estado de Direito (governo das leis) que traduz a necessidade da limitação do poder absoluto do soberano. Esta limitação é alcançada pela adoção do Princípio da Separação dos Poderes, de Montesquieu, segundo o qual o exercício do poder político é dividido entre os órgãos do Poder - Executivo, Legislativo e Judiciário - que exercem com exclusividade as funções típicas de administração, de legislação (e também de poder financeiro) e de jurisdição, respectivamente". ${ }^{139}$
\end{abstract}

Nina Beatriz Stocco Ranieri também relaciona controle e poder e explica ser o primeiro necessário em um Estado Democrático. Assevera a autora:

\footnotetext{
"As relações entre controle e poder no regime democrático, portanto, se perfazem na dimensão legal racional: não há poder sem controle, não há controle sem previsão. Logo, se por um lado é necessário que ao Executivo sejam garantidos poderes suficiente à dominação dos conflitos
}

\footnotetext{
${ }^{138}$ CAVALCANTI, Augusto Sherman. Aspectos da competência julgadora dos Tribunais de Contas. Revista de Direito Administrativo. v. 237. Rio de Janeiro: Renovar, jul.-set., 2004. p. 328.

${ }^{139}$ FAGUNDES, Tatiana Penharrubia. A função do Tribunal de Contas no Estado Democrático de Direito brasileiro. In: MESSA, Ana Flávia; THEOPHILO JÚNIOR, Roque (Org.). Estado e Economia: estudos em homenagem a Ademar Pereira. São Paulo: Saraiva, 2011. p. 233.
} 
sociais, de outro se impõe a ênfase nos controles jurídicos como meio de realização da exigência democrática". ${ }^{140}$

Impende, pois, apresentarmos um conceito para o controle, destacando desde logo que a sua fase áurea ocorreu no Estado de Direito. Somente depois é que traremos a definição do controle na administração pública, seara em que se encontram as contas municipais.

Assim como o vocábulo "poder", a expressão "controle” também possui diversas acepções.

Manoel Gonçalves Ferreira Filho ${ }^{141}$ explica que existem dois significados para a palavra controle: um sentido forte - "comando" - proveniente do direito inglês "control" e um sentido fraco - "fiscalização, verificação", este decorrente do direito francês "contrôle".

Gérard Bergeron ${ }^{142}$, publicista francês, é mais detalhista e traz seis definições para o controle: dominação; direção; limitação; vigilância; verificação; e registro. O sentido de dominação assemelha-se ao trazido por Manoel Gonçalves Ferreira Filho. Assevera o autor francês que esta acepção - de dominação - é mais utilizada no direito inglês do que no francês. Odete Medauar, acerca desta definição, assevera que nela “(...) se associam as idéias de subordinação, centralização, monopolização". ${ }^{143}$ O publicista francês cita o controle de um partido político, o controle econômico ou militar sobre um país e o ditador que controla um povo como exemplos de dominação. Controle como

${ }^{140}$ RANIERI, Nina Beatriz Stocco. Governabilidade e Estado Democrático de Direito: o uso e o controle das medidas provisórias. In: GARCIA, Maria. (Coord.). Democracia hoje. Um modelo político para o Brasil. São Paulo: Instituto Brasileiro de Direito Constitucional, Celso Bastos Editor, 1997. p. 116. Continua, a autora, exempleficando este cenário de controle no ordenamento pátrio brasileiro: "Veja-se que a Constituição de 1988, além das leis delegadas (art. 68), do poder de veto e de iniciativa privativa de leis (art. 84, incisos III, IV, V, VI e XXVI), que já assegurariam ao Chefe do Poder Executivo competências legislativas extraordinárias, concedeu-lhe o poder de intervenção discricionária direta (art. 62), sem prejuízo da democracia representativa $\left(\operatorname{art.} 1^{\circ}\right.$ ), da autonomia da sociedade civil em relaão ao aparato do Estado, da forma federativa $\left(\operatorname{art.~} 1^{\circ}\right.$ ) e da separação de poderes (art. $2^{\circ}$ ); o que está a evidenciar que a atuação do Executivo, com fundamento no art. 62, não pode exceder os limites do sistema jurídico-institucional, como também não pode o Legislativo se omitir do controle político ou o Judiciário deixar de atuar conforme a Constituição, independente dos efeitos que possam resultar desse controle, justamente para que se legitimem e se consolidem democraticamente as políticas assim implantadas". Idem. pp. 118-119.

${ }^{141}$ FERREIRA FILHO, Manoel Gonçalves. Poder Judiciário... Op. cit. p. 212.

${ }^{142}$ Os seis sentidos da palavra "controle" (dominação, direção, limitação, vigilância, verificação e registro) são explicados por Gérard Bergeron nas pp. 77-78. Para detalhes, consultar: BERGERON, Gérard. Fonctionnement de l'État. $2^{\mathrm{a}}$ ed. Paris: Librairie Armand Colin, 1965. pp. 77-78. Disponível em: <http://classiques.uqac.ca/contemporains/bergeron_gerard/fonctionnement_de_Etat/fonctionnement_de_Etat _sommaire.html>, acesso em 21 de ago. de 2011.

${ }_{143}^{143}$ MEDAUAR, Odete. Controle da administração pública. São Paulo: Revista dos Tribunais, 1993. p. 14. 
direção significa influência decisiva, direção efetiva, gestão eficaz, ser mestre em uma situação. É o caso do controle dos negócios, dos investimentos. Como limitação, apresenta o controle um lado negativo, restritivo ou inibidor, como por exemplo, o controle (limitação) do câmbio, da importação ou a aposição de um veto. Enquanto vigilância, o controle compreende a ideia de continuidade, tal como o controle da gestão das finanças ou a hipótese de se controlar as ações de alguém, criticando-o e censurando-o. Para Odete Medauar, esta forma de controle pode ser traduzida também como fiscalização, com a "idéia de supervisão, inspeção, censura". ${ }^{144}$ Diferentemente, considerando-se o controle como verificação, não se encontra nele o sentido de continuidade e sim o de exame sobre objetos específicos, como o controle do orçamento ou a atividade do controlador de trem, exemplos estes do publicista francês. Em cenário pátrio, Odete Medauar confere ao controle, enquanto "verificação", também os sentidos de "exame e constatação". ${ }^{145}$ Por fim, controle pode ter o significado de registro, entendido como um simples ato de gravação. É este, aliás, o sentido original da palavra controle e que "designa a mais fraca intensidade do ato de controle". ${ }^{146}$

De todos estes conceitos, é relevante para o nosso trabalho o controle como "vigilância" (ou "fiscalização", na lição de Odete Medauar), já que o controle das contas municipais - de responsabilidade do Poder Legislativo (Câmara Municipal), com o auxílio do Tribunal de Contas no âmbito do município, exercido sobre os atos que envolvam dinheiro público utilizados pelo Poder Executivo (Prefeito ou agentes públicos) - tem a característica de continuidade. Trata-se, no caso, de continuidade perene e, desse modo, sempre haverá o controle - a "vigilância", a "fiscalização" -, realizado tanto pelo Poder Legislativo, já que a função de controle é uma de suas atividades típicas, como pelo Tribunal de Contas, órgão igualmente de controle, cuja função primordial é a fiscalização (contábil, financeira, orçamentária, operacional e patrimonial, na exegese do artigo 70, caput, da Constituição Federal) das contas públicas.

É possível, ainda, no âmbito do nosso trabalho, conceber o controle como verificação, presente, por exemplo, quando o Poder Legislativo aprova a lei orçamentária ou o Tribunal de Contas analisa um contrato ou suspende uma licitação, dentre outros. Ressalte-se, no entanto, uma particularidade: em que pese tratar-se de uma

\footnotetext{
${ }^{144}$ MEDAUAR, Odete. Controle da administração pública. São Paulo: Revista dos Tribunais, 1993. p. 15. ${ }^{145}$ MEDAUAR, Odete. Controle da administração pública. São Paulo: Revista dos Tribunais, 1993. p. 15.

${ }^{146}$ MEDAUAR, Odete. Controle da administração pública. São Paulo: Revista dos Tribunais, 1993. p. 15.
} 
atividade isolada de "verificação", faz ela parte de algo maior, que é o controle (como "fiscalização") do uso do dinheiro público. Isto significa que, em matéria de contas públicas, o controle como "vigilância" está sempre presente - daí porque é perene -, mesmo que se trate, em determinado caso, da "verificação" de um ato isolado.

Jose Anibal Cagnoni, autor uruguaio, por sua vez, atribui ao controle dois significados: de dominação como “(...) o poder sobre coisas, acontecimentos ou pessoas". ${ }^{147}$ (tradução nossa) e o sentido que a este se opõe, ou seja, controle como limitação do poder ou do domínio ${ }^{148}$. Acerca desta última acepção, oferece o autor a definição de Sánchez Agresta:

\begin{abstract}
"O controle significa essencialmente: a faculdade de limitar, impedir ou vetar; ou a faculdade de participar, isto é, de intervir em uma decisão, de tal forma que quem exerce o controle tenha uma influência efetiva na decisão que o controlado adota; ou a faculdade de inspecionar ou verificar se uma conduta corresponde não apenas a um mandamento constitucional ou legal, como também aos fins gerais do ordenamento jurídico-político e aos critérios de oportunidade que devem ser adotados". ${ }^{149}$ (tradução nossa)
\end{abstract}

Extraem-se do conceito diversas finalidades da atividade de controle, que vão desde apenas verificar se a conduta do órgão controlado está de acordo com o princípio da legalidade (é o controle "verificação" de que trata Gérard Bergeron, anteriormente estudado), até a possibilidade de o controlador influenciar a tomada de decisão pelo controlado, sendo exemplo desta última situação um edital de licitação elaborado por uma secretaria municipal, que é reformulado para atender às recomendações de ampla competitividade - que visa a respeitar os princípios da isonomia e da igualdade de oportunidade para todos - feitas pelo Tribunal de Contas. O controle pode, ainda, exteriorizar-se para inspecionar uma conduta verificando se ela está conforme com a

\footnotetext{
${ }^{147}$ Sobre o conceito de controle na acepção dominação, profere Jose Anibal Cagnoni: “(...) o poder sobre cosas, acontecimientos o personas". E continua: "la idea es el dominio, la de que los encargados en cada caso se han enseñoreado del fenómeno; señorio, dominio, mando". CAGNONI, Jose Anibal. El derecho constitucional uruguayo. $2^{\mathrm{a}}$ ed. actual. e ampl. Uruguay: UY Libros, 2006. p. 353.

148 "Es exactamente, el sentido del fenómeno que se le opone, que contradice, o que como mejor expresión sobre su sentido, limita al poder o dominio". CAGNONI, Jose Anibal. El derecho constitucional uruguayo. $2^{\mathrm{a}}$ ed. actual. e ampl. Uruguay: UY Libros, 2006. p. 354.

149 "El control significa esencialmente: la facultad de limitar, impedir o vetar; o la facultad de participar, esto es, de intervenir en una decisión de tal forma que quien ejerce el control tenga una influencia efectiva en la decisión que se adopta por outro; o la facultad de inspeccionar o verificar que una conducta corresponde no sólo a lo que un precepto constitucional o legal ordena, sino también a los fines generales del ordenamiento jurídico-político y a los criterios de oportunidad con que deber cumplirse". CAGNONI, Jose Anibal. El derecho constitucional uruguayo. $2^{\mathrm{a}}$ ed. actual. e ampl. Uruguay: UY Libros, 2006. p. 355.
} 
Constituição, as leis e o ordenamento jurídico. Sob este prisma, citamos como exemplo, agora no âmbito do Poder Legislativo, o pedido de informações, e, em seara federal, a convocação, pela Câmara dos Deputados e pelo Senado Federal, de Ministros de Estado para prestarem, pessoalmente, informações sobre um determinado assunto caracterizando, a ausência sem justificativa adequada do convocado, crime de responsabilidade. ${ }^{150}$

Discordamos, contudo, da parte final da explicação do autor, que autoriza o controlador a interferir nos "critérios de oportunidade que devem ser adotados" pelo controlado. Isto porque, em nosso entendimento, no tocante às despesas públicas, tais critérios correspondem à margem de discricionariedade que a lei confere ao administrador público para decidir como aplicar os recursos de que dispõe. Ou seja, a decisão do administrador é pautada pela lei e, por isso, não se admite que o controlador obrigue o controlado a usar o dinheiro de uma maneira e não de outra, desde que conformes ao ordenamento jurídico. Daí porque, nem o Tribunal de Contas, nem o Poder Legislativo estão autorizados a interferir no critério de conveniência e oportunidade que o Chefe do Executivo ou o agente público escolhem para utilizar os recursos públicos. Podem, apenas, avaliar se o dinheiro foi utilizado de maneira a respeitar os princípios constitucionais e legais do ordenamento jurídico e, em caso negativo, apenar os seus responsáveis. Trata-se, no caso, de um controle no sentido de "verificação", vez que inspeciona, fiscaliza um ato integrante da atividade administrativa, sem a característica da continuidade.

Voltando ao conceito de Jose Anibal Cagnoni, pedimos vênia para discordar do autor quando assevera que "o controle significa essencialmente: a faculdade de limitar (...)"151 (grifos nossos).

É que, levando-se em consideração as contas municipais em cenário pátrio, quer se trate da observância ao princípio da legalidade, quer diga respeito a influenciar a decisão do controlado, há, na verdade, uma limitação imposta (e não uma "faculdade") pelos órgãos controladores - o Poder Legislativo municipal com a participação do Tribunal de Contas - sobre os gastos públicos realizados pelo órgão controlado - o Poder Executivo municipal -, sejam estes gastos efetivados pelo Prefeito ou por servidor público.

\footnotetext{
${ }^{150}$ É o que dispõe o caput do artigo 50 da Constituição Federal de 1988.

${ }^{151}$ CAGNONI, Jose Anibal. Op. cit. p. 355.
} 
E isto porque o dinheiro público é a mola propulsora das atividades do Estado, ou seja, este necessita de recursos para desenvolver as políticas públicas e para atingir os seus fins, que devem ser perseguidos em prol da comunidade. Entretanto, como o Estado, através de seus representantes, utiliza dinheiro que não lhe pertence, tal uso deve ser controlado (fiscalizado) prévia, concomitante e posteriormente, de maneira contínua, pelo órgão controlador, não se admitindo outra conduta deste, que não uma atividade atuante sobre essa utilização. Não tem, assim, o controlador, "faculdade" e sim o "dever" 152 de limitar.

Ressalvamos, contudo, que a limitação não tem como cerne impedir o órgão controlado de desempenhar as suas atividades, mas objetiva, tão somente que estas sejam executadas sob o manto da constitucionalidade e da legalidade, de tal sorte que um órgão, que não o que utiliza o dinheiro público, possa fiscalizar a ação de quem o usa, responsabilizando, se necessário, o mau gestor público. O órgão controlador, que objetiva a proteção do erário, funciona, pois, como um freio e contrapeso ao órgão controlado, revelando-se, portanto, a função de controle indispensável. Trata-se, ademais, do controle no seu sentido de continuidade (ou do controle verificação como explicita Gérard Bergeron).

Cuidando, agora, do "controle da Administração Pública" - e não genericamente do termo "controle" -, trazemos à colação, no cenário pátrio, a definição proposta por Maria Sylvia Zanella Di Pietro.

Antes, porém, é preciso informar, como faz a autora, que quando se alude a "controle da Administração Pública" não se está restringindo tal controle apenas aos órgãos do Poder Executivo. Pelo contrário. Abrange, também, os Poderes Legislativo e Judiciário, quando estes exercem função administrativa. A origem remota desta forma de controle decorre da época da Revolução Francesa, quando foi editada a Declaração Universal dos Direitos do Homem e do Cidadão (1789) e cujo artigo 15 pregava: "a

\footnotetext{
${ }^{152}$ Reforça este nosso posicionamento acerca do dever de controlar a lição de Gérard Bergeron, segundo a qual, na atividade econômica e financeira o controle tem um sentido forte: "o de influenciar preponderantemente a orientação geral dos negócios". Nas palavras do autor: "en activité économique et financière, le contrôle a une acception généralement très forte. Il désigne 'l'influence prépondérante sur l'orientation générale des affaires' selon un arrêt de la Cour Permanente de Justice Internationale (...)". BERGERON, Gérard. Op. cit. p. 72.
} 
sociedade tem o direito de pedir conta a todo agente público quanto à sua administração" ${ }^{\prime 153}$, como já abordado anteriormente.

Assim, quer se trate de servidor público ou de agente político, quer, ainda, pertençam estes a qualquer dos Poderes, a atividade está sujeita a uma fiscalização contínua, que é praticada por um órgão de controle.

Voltando, agora, ao conceito de "controle da Administração Pública", considerada no seu sentido lato, a Professora Maria Sylvia Zanella Di Pietro define-o como sendo “(...) o poder de fiscalização e correção que sobre ela exercem os órgãos dos Poderes Judiciário, Legislativo e Executivo, com o objetivo de garantir a conformidade de sua atuação com os princípios que lhe são impostos pelo ordenamento jurídico". 154

Visto o conceito de controle passamos, em seguida, às suas características.

\subsection{As características do controle}

O controle possui três características importantes: ele é acessório, é inerente ao poder e é retroativo, este, ao menos, quando o controle é posterior.

Jose Anibal Cagnoni ${ }^{155}$ assevera que a acessoriedade decorre do fato de que o controle só existe em razão do poder. Aduz que o "o verdadeiro sentido" do controle, em um Estado de Direito, encontra-se na limitação do exercício do poder pelos órgãos do Estado, enquanto em um Estado autoritário ou em um governo de fato, o controle, se existente, não limita o poder, no máximo, reforça-o ${ }^{156}$. Ainda sobre a acessoriedade, explica ser ela jurídica no Estado de Direito, uma vez que a obediência do poder aos mecanismos de controle decorre da sua subordinação ao ordenamento jurídico.

\footnotetext{
153 Declaração Universal de Direitos do Homem e do Cidadão de 1789. Disponível em: < http://www.direitoshumanos.usp.br/index.php/Documentos-anteriores-à-criação-da-Sociedade-das-Naçõesaté-1919/declaracao-de-direitos-do-homem-e-do-cidadao-1789.html>, acesso em 05 de jan. 2012.

${ }^{154}$ DI PIETRO, Maria Sylvia Zanella. Direito administrativo. $21^{a}$ ed. São Paulo: Atlas, 2008. p. 691.

${ }^{155}$ CAGNONI, Jose Anibal. Op. cit. p. 356.

156 Com efeito. Sobre o controle no Estado autoritário, explica Jose Anibal Cagnoni: "En un Estado autoritario o dictatorial, o en un gobierno que sin corresponder a un Estado autoritario o a um Estado dictatorial, sea en sí un gobierno de facto, un gobierno autoritario, el control no es más que un reforzamiento, una categoría del ejercicio del poder, no destinado a limitarlo sino precisamente y al contrario, destinado a hacerlo más efectivo". Idem. Ibidem.
} 
Outra característica é a inerência do controle. Também considerando o Estado de Direito, assevera Jose Anibal Cagnoni:

"No Estado de Direito a existência (e o exercício efetivo) do controle é inerente (à existência) e ao exercício do poder político. O que significa em seu sentido etimológico e jurídico que não se podem separar; não se concebe separar o controle do exercício do poder político". ${ }^{157}$ (tradução nossa)

Menciona, ainda, como característica, a retroatividade. Para o autor citado, a ação de controle está sempre ligada a um acontecimento no passado. Vale dizer, só nasce o controle para verificar uma atividade que já ocorreu. Explica que esta premissa é válida tanto para o controle posterior como para o prévio, porque, mesmo neste caso, o controlador deve levar em conta a "potencial emanação do ato"158 a ser controlado.

Concordamos em parte com a explicação do autor. Não há dúvidas de que a retroatividade ocorre para o controle posterior. Não para o prévio, pensamos. Entendemos este último, como o controle que objetiva evitar que um ato inconstitucional, ilegal ou que fira o interesse público seja praticado. Daí porque uma série de medidas controladoras deve ser executada. Pensamos, pois, que não é possível considerar a situação de retroatividade explanada pelo autor. A retroatividade só é cabível, para nós, para o controle posterior e, no máximo, para o concomitante, na medida em que, neste, o controle atua quando o ato continua produzindo efeitos, fazendo cessá-los para evitar abusos, ilegalidades ou inconstitucionalidades.

Apresentadas as características do controle, passamos, em seguida, ao estudo dos sistemas de controle existentes no mundo.

\footnotetext{
157 "En el Estado de Derecho la existência (y el ejercicio efectivo) del control es inherente a (la existência) y la ejercitación del poder activo. Lo que significa em su sentido etimológico y jurídico que no puede separarse, no se concibe separar, al control del ejercicio del poder activo". Idem. p. 357.

${ }^{158}$ Idem. Ibidem.
} 


\title{
2.4. Os sistemas de controle
}

\subsubsection{As "Entidades de Fiscalização Superiores" - (EFS) ou "Instituições Supremas de Controle - (ISC) das contas públicas}

O controle dos gastos públicos sempre pertenceu ao Poder

Legislativo. Com o desenvolvimento da democracia, em que os parlamentares representam a vontade popular, este controle passou para as mãos do povo, que é o verdadeiro detentor do poder político.

Auxiliando-o na realização do controle, mas não no sentido de subordinação, estão as "Entidades de Fiscalização Superiores" - (EFS) ou "Instituições Supremas de Controle" - (ISC) ${ }^{159}$, que foram criadas para realizar a "fiscalização financeira do Estado"160 e têm um cunho eminentemente técnico. Sobre elas, preleciona Marcos Valério de Araújo:

\begin{abstract}
"Torna-se fundamental a existência de um órgão especializado e independente que, por delegação de competência da Sociedade e, em segunda instância, do próprio Poder Legislativo, realize o controle técnico e legal da gestão financeira governamental, certificando-se do correto uso dos recursos comunitários". ${ }^{161}$ (grifos nossos)
\end{abstract}

\footnotetext{
${ }^{159}$ No IV Encontro das Instituições Supremas de Controlo da Comunidade dos Países de Língua Portuguesa concluiu-se que o controle externo pertencia aos Parlamentos, porém, é necessária a existência de "órgãos especializados e dirigidos ao controle dos gastos públicos, que lhes possam prestar o apoio necessário ao cumprimento de sua missão fiscalizadora". Estes órgãos são as Instituições Supremas de Controle - (ISC), também chamadas de Entidades de Fiscalização Superiores - (EFS) ou Instituições Superiores de Auditoria. VILAÇA, Marcos. Tema II: As relações das Instituições Supremas de Controlo com o Parlamento. IV Encontro das Instituições Supremas de Controlo da Comunidade dos Países de Língua Portuguesa. p. 43. Disponível em: <http://www.tcontas.pt/pt/publicacoes/outras/enc_cplp/4enc.pdf>, acesso em 14 de abr. 2011. O termo - Instituições Supremas de Controle - decorre do INTOSAI ("Internacional Organization of Supreme Audit Institucions") que, aportuguesado significa "Organização Internacional das Instituições Superiores de Controle das Finanças Públicas" e se trata de uma organização de nível mundial, reconhecida pelas Nações Unidas, que se reúne para discutir temas relacionados ao controle externo e conta com a participação de mais de cento e quarenta Estados soberanos que possuem Tribunais de Contas ou órgão congênere para realizar o controle externo. Cf. GUALAZZI, Eduardo Lobo Botelho. Regime jurídico dos Tribunais de Contas. São Paulo: Revista dos Tribunais, 1992. p. 36.

${ }^{160}$ ARAÚJO, Marcos Valério de. Como controlar o Estado: reflexões e propostas sobre o controle externo nas Américas, Portugal e Espanha. Brasília: UNITEC, 1992. Biblioteca Digital do Tribunal de Contas da União. Trabalho premiado pelo Tribunal de Cuentas de Espana e pela Sociedad Estatal Quinto Centenário. p. 16. Disponível em: <http://portal2.tcu.gov.br/portal/pls/portal/docs/2058856.PDF>, acesso em 20 de out. 2011.

${ }^{161}$ Idem. pp. 15-16.
} 
Sobre a importância das "Entidades de Fiscalização Superior" ou "Instituições Supremas de Controle" nos regimes democráticos, profere José F. F. Tavares:

\begin{abstract}
Muito embora este tipo de órgãos de controlo financeiro possa existir em quaisquer regimes políticos, visando assegurar a legalidade estabelecida, o certo é que é nos regimes democráticos que assume toda a sua plenitude, tendo então como missão fundamental informar os cidadãos e os seus representantes (no Parlamento) de como são geridos, em vários planos, os recursos financeiros e patrimoniais públicos que, na realidade, lhes pertencem com o eventual e consequente apuramento de responsabilidade nos termos legalmente definidos". ${ }^{162}$ (grifos nossos)
\end{abstract}

Como se depreende, a prestação de contas mantém relação direta com a democracia e visa não só a informar o cidadão, por meio do Parlamento, de como os valores são geridos mas, também, a apurar as responsabilidades do mau gestor, nos termos da lei.

\title{
2.4.2. A independência das "Entidades de Fiscalização Superiores" - (EFS) ou "Instituições Supremas de Controle" - (ISC)
}

As "Entidades de Fiscalização Superiores" ou "Instituições Supremas de Controle" foram criadas como órgãos técnicos e independentes ${ }^{163}$ cuja especialidade é fiscalizar - sob o aspecto técnico - as contas públicas em nome do povo.

No mesmo sentido, defendendo a independência das Entidades de Fiscalização Superiores (ou Instituições Supremas de Controle) é o entendimento do então Ministro do Tribunal de Contas da União, Marcos Vilaça, proferido no IV Encontro das Instituições Supremas de Controlo da Comunidade dos Países de Língua Portuguesa, ocorrido em Portugal:

“(...) o relacionamento mantido entre aquelas [Instituições Supremas de Controle] e os Parlamentos não se deve pautar pela submissão hierárquica ou funcional.

\footnotetext{
162 TAVARES, José F. F.. O Tribunal de Contas: do visto em especial: conceito, natureza e enquadramento na actividade de administração. Coimbra: Almedina, 1998. pp. 23-24.

${ }^{163}$ Em cenário pátrio discute-se se os Tribunais de Contas são ou não independentes. Há correntes que defendem a independência e a autonomia deles e outras que os entendem subordinados ao Poder Legislativo. Delas falaremos detalhadamente no Capítulo III, item 3.2 (A independência e a autonomia do Tribunal de Contas brasileiro)
} 
A independência das Instituições Supremas de Controle geralmente só é lembrada em relação ao Poder Executivo. No entanto, essa independência deve assegurar também que as ISC [Instituições Supremas de Controle] não sejam afetadas por influências políticas oriundas do Poder Legislativo". ${ }^{164}$ (grifos nossos)

E discorrendo sobre os aspectos negativos que as Entidades de Fiscalização Superiores portam quando existe um vínculo de subordinação com o Poder Legislativo, o então Ministro Marcos Vilaça traz o discurso do Dr. H. Peschar, exPresidente da Instituição de Controle Superior da Holanda, que afirma:

\footnotetext{
“(...) se rechaça a idéia de uma ISC [Instituição Suprema de Controle] servindo e dependendo do Parlamento. Uma instituição independente é capaz de assegurar que o público e o próprio Parlamento recebam informações objetivas, não influenciadas politicamente. Em uma ISC [Instituições Supremas de Controle] dependente do Parlamento certos assuntos podem não ser investigados ou os resultados podem não ser publicados, se uma maioria no Parlamento se considerar, em parte, responsável pela política seguida". ${ }^{165}$ (grifos nossos)
}

Com efeito, concordamos com os entendimentos expostos. As Entidades de Fiscalização Superiores, entre as quais se insere o Tribunal de Contas brasileiro, devem ser independentes, sob pena de servirem a eventuais desmandos do Poder Legislativo e não conseguirem desenvolver o seu papel - de controladoras dos gastos públicos no aspecto técnico, isto é, no aspecto que envolva a contabilidade, a legalidade das receitas e das despesas etc - de maneira íntegra, correta, verdadeira.

Exemplos desta independência são, mais uma vez, trazidos pelo Ministro Marcos Vilaça. Segundo o autor, devem as Instituições Supremas de Controle: "determinar, elas próprias, os órgãos a serem fiscalizados e o momento em que deverão ocorrer as fiscalizações. Mais, que isso, as "Instituições Supremas de Controle" devem ter competência para determinar os meios pelos quais ocorrerão as fiscalizações, sem a necessidade de prévio consentimento ou comunicação aos Parlamentos". ${ }^{166}$

Analisaremos, em seguida, os tipos de "Entidades de Fiscalização Superiores" ou "Instituições Supremas de Controle" existentes no mundo destacando,

\footnotetext{
${ }^{164}$ VILAÇA, Marcos. Op. cit. p. 44.

165 Idem. Ibidem.

${ }^{166}$ Idem. p. 45.
} 
desde já, que a maioria dos países democráticos possui um órgão de controle técnico das contas públicas.

\subsubsection{A Controladoria Geral, o Tribunal de Contas e o sistema misto}

Observada a importância das "Entidades de Fiscalização Superiores" ou "Instituições Supremas de Controle", Marcos Valério de Araújo ${ }^{167}$ ensina existirem dois tipos de "Entidades de Fiscalização Superiores" ou "Instituições Supremas de Controle": 1) as chamadas Controladorias Gerais (ou Auditorias Gerais), que adotam um modelo unipessoal, encontradas no Chile, Peru e Costa Rica; e 2) os Tribunais, Cortes e Câmaras de Contas, que possuem um modelo colegiado, como no Brasil, Espanha, Portugal e Uruguai. Há, ainda, neste grupo, países, como a Guatemala e o Paraguai, que possuem a Controladoria Geral e, também, o Tribunal de Contas sendo, neste caso, este subordinado àquela.

O mesmo autor, em outra classificação, assevera ainda que há países que: 1) fiscalizam, sancionam e exigem ressarcimento, como são os casos do Brasil, da Espanha e de Portugal; 2) outros que apenas fiscalizam por meio de seu Tribunal de Contas, como o Uruguai; 3) finalmente, alguns países apenas fiscalizam através de suas Controladorias, como o Chile, Colômbia, Costa Rica e México.

Por outro lado, Emerson Cesar da Silva Gomes, por sua vez, aduz existirem quatro modelos de "Entidades de Fiscalização Superiores" ou "Instituições Supremas de Controle" na União Europeia: "as denominadas 'Cortes', com função judicial; os órgãos colegiados sem função judicial; os órgãos independentes chefiados por um Auditor Geral; e os órgãos de auditoria chefiados por um Auditor Geral, mas inseridos na estrutura governamental" ${ }^{168}$, sem contar a Corte de Contas da Áustria, que é chefiada

\footnotetext{
${ }^{167}$ Idem. p. 18.

168 GOMES, Emerson Cesar da Silva. Tribunais de Contas do Brasil: composição, organização e competências. Conteúdo Jurídico: Brasília-DF: 22 jun. 2009. p. 1. Disponível em: <http://www.conteudojuridico.com.br/artigos\&ver=2.24213>, acesso em 07 de jul.2011. O autor explica cada modelo. Assinala que as Entidades de Fiscalização Superiores da França, Bélgica, Portugal, Espanha, Itália e Grécia são equiparadas às Cortes e que na Grécia e em Portugal elas integram o Poder Judiciário sendo, neste último, equiparadas às demais Cortes. Por sua vez, Holanda, Alemanha e Luxemburgo possuem uma estrutura colegiada, sem função judicial, sendo, este também o caso do Tribunal de Contas Europeu. Irlanda, Reino Unido e Dinamarca possuem um órgão de auditoria chefiado pelo Auditor Geral e, na Suécia e na Finlândia, as auditorias integram a estrutura dos governos sendo, nestes países, duas as Entidades de Fiscalização Superiores: um “(...) responsável pelo governo e conduzindo exames detalhados, e o segundo, chefiado por membros do Parlamento e auxiliados por um pequeno secretariado, responsável pelo Poder
} 
por um Presidente, mas que tem funções de auditoria nos âmbitos local, regionais e central do governo ${ }^{169}$.

O mencionado autor entende mais adequada, no entanto, a classificação de José F. F. Tavares, que distribui as Entidades de Controle Superiores ou "Instituições Supremas de Controle" em três grupos e assim se manifesta:

\begin{abstract}
"Em geral, os tribunais de contas têm natureza colegial e exercem a função de fiscalização/auditoria e a função jurisdicional de julgamento, maxime, da responsabilidade financeira. Nalguns casos, tendem a privilegiar o controlo da legalidade e da regularidade financeiras. (...) O sistema de auditor geral, acolhido sobretudo no mundo anglosaxónico, caracteriza-se por haver um órgão singular, com funções exclusivas de auditoria, tendendo a privilegiar o controlo da boa gestão financeira.

Há, porém, Estados que instituíram um órgão de controlo financeiro de natureza mista, combinando características dos sistemas de tribunal de contas e de auditor geral. Na verdade, há exemplos de Tribunais de Contas, com a sua natureza colegial, que não têm poderes jurisdicionais, exercendo apenas a função de auditoria suprema e sem poderes de fiscalização prévia, mas tão só concomitante e sucessiva". ${ }^{170}$ (grifos do autor)
\end{abstract}

Ainda de acordo com o autor precitado, adotam Tribunais de Contas os países da Espanha, França, Bélgica, Itália, Luxemburgo, Cabo Verde, GuinéBissau e Moçambique; a Auditoria Geral existe no Reino Unido, Estados Unidos da América, Irlanda, Canadá, Dinamarca, Noruega e Suécia e os sistemas mistos são representados pelo Tribunal de Contas Europeu e pelos Tribunais de Contas alemão e holandês.

Depreende-se, daí, que as estruturas das Entidades de Fiscalização Superiores ou Instituições Supremas de Controle existem em várias partes do mundo, em cada país com especificidades próprias. Todas, no entanto, convergem a um ponto comum: o controle dos gastos públicos nos seus aspectos da legalidade, da economicidade e da regularidade é realizado por um órgão especializado denominado "Entidade de Fiscalização Superior" - (EFS) ou “Instituição Suprema de Controle" - (ISC).

Legislativo. Uma alteração constitucional na Finlândia em 2000, no entanto, tornará a EFS independente do Ministério das Finanças, que se reportará exclusivamente ao Parlamento”. Idem. p. 2.

${ }^{169}$ Idem. p. 1.

${ }^{170}$ TAVARES, José F. F.. Op. cit. p. 32. 


\subsubsection{Características dos sistemas Controladoria Geral e Tribunal de Contas}

Abordaremos, agora, de modo resumido, as características dos dois principais sistemas de controle: a Controladoria Geral e o Tribunal de Contas.

A Controladoria Geral - órgão unipessoal - é o sistema adotado originalmente em países anglo-saxões e que utilizam o common law, sendo seus expoentes máximos os Estados Unidos da América e a Inglaterra. Na América Latina, também adotam este sistema o Chile, o Peru e a Costa Rica, graças à influência americana

O controle externo, nos Estados Unidos da América, é realizado pelo General Accounting Office, que é chefiado pelo Auditor-Geral e, na Inglaterra, o controle é feito pelo General Comptroller and Auditor ${ }^{171}$. Em ambos, os membros têm as mesmas garantias conferidas à magistratura, encontrando-se em posição de independência em relação aos órgãos controlados, inclusive ao Chefe do Executivo. Paulo Soares Bugarin explica que o Auditor-Geral e o General Comptroller and Auditor são escolhidos e nomeados pelo Parlamento e têm mandato fixo. Devem ser detentores de reputação moral e intelectual e de notórios conhecimentos técnicos da matéria, além de independência político-partidária para exercer as tarefas de fiscalização e de controle externo sobre as contas públicas. ${ }^{172}$

Francisco Eduardo Carrilho Chaves assevera, ainda, que as Controladorias Gerais se diferem dos Tribunais de Contas porque não possuem a função judicante, competindo-lhes, então, "examinar essa gestão [do administrador público, chamada 'contas dos responsáveis'], colecionando dados e argumentos, para subsidiar sua avaliação pelo titular do Controle Externo e pela opinião pública". ${ }^{173}$ Esses órgãos manifestam-se, assim, conclusivamente sobre as contas, mas não as julgam. Ademais, as

\footnotetext{
${ }^{171}$ Odete Medauar explica que o General Comptroller and Auditor "é um alto funcionário que permanece em funçção enquanto atue de modo correto (during good behavior); só pode ser destituído pela Coroa por moção conjunta das duas Câmaras do Parlamento". Assevera, ainda, que ele desempenha duas ações principais: "fiscaliza pagamentos da conta aberta no banco da Inglaterra (Consolidated Fund) depois de certificar-se de que os recursos foram votados para a respectiva finalidade; exerce auditoria sobre as contas de todos os departamentos do governo e assegura de que o dinheiro seja aplicado em finalidades para as quais foi votado; é obrigado a apresentar anualmente ao Parlamento relatório sobre contas orçamentárias; como já se mencionou, presta assessoria para a Comissão de Contas Públicas da Câmara dos Comuns; dispõe de amplo grupo de auditores, alguns dos quais permanecem junto aos departamentos do governo realizando auditoria de contas ou acompanhando as despesas". MEDAUAR, Odete. Controle da administração pública pelo Tribunal de Contas. Revista de Informação Legislativa. Ano 27, n. 108. Brasília: out./dez., 1990. p. 112.

172 Para detalhes conferir: BUGARIN, Paulo Soares. O princípio constitucional da economicidade na jurisprudência do Tribunal de Contas da União. $2^{\mathrm{a}}$ ed. rev. e ampl. Belo Horizonte: Fórum, 2011. p. 48.

${ }^{173}$ CHAVES, Francisco Eduardo Carrilho. Op. cit. p. 11.
} 
Controladorias Gerais não aplicam sanções administrativas. Se houver notícia de desvios ou ilícitos penais praticados, as informações devem ser encaminhadas ao Poder Judiciário para a propositura de ação específica. O controle político, por seu turno, é realizado pelo Parlamento e pela opinião pública ${ }^{174}$.

Os Tribunais de Contas, Câmaras ou Cortes de Contas, por sua vez, são órgãos colegiados que têm como cerne auxiliar ou cooperar com o Poder Legislativo na função do controle externo das contas do Executivo. Desenvolveram-se em países latinos da Europa, como França e Espanha, mas também são adotados em países da América Latina, como o Uruguai. Seus membros têm garantias institucionais que lhes garantem a independência funcional. Além disso, "esse órgão exerce as funções em caráter autônomo e sem qualquer liame com o Chefe do Executivo". ${ }^{175}$

Francisco Eduardo Carrilho Chaves afirma que os Tribunais de Contas têm natureza judicante sobre "a gestão da coisa pública, isto é, sua competência de julgar, punir e emitir determinações de caráter compulsório aos controlados"176, o que não ocorre com as Controladorias Gerais que, na ausência do poder judicante, têm os seus relatórios apreciados ${ }^{177}$ pelo Parlamento. Aplicam, além disso, sanções administrativas pela má gestão da coisa pública e a maioria das determinações ao Poder Executivo é conferida pelo próprio órgão de Contas. O autor explica, ainda, que os Tribunais de Contas são órgãos autônomos "que funcionam junto aos titulares do Controle Externo"178, sem que, no entanto, esta vinculação administrativa signifique subordinação ao Poder Legislativo, já que suas atribuições são distintas: o Tribunal de Contas realizando julgamentos técnicos das contas públicas e o Poder Legislativo, julgamento político.

\subsubsection{Modelos de Tribunais de Contas}

A doutrina aponta três clássicos modelos de Tribunais de Contas: o italiano, o francês e o belga. Nosso intuito é, nesta fase, analisar cada um deles. Estudaremos, ainda, o modelo português, graças à semelhança com o modelo pátrio no

\footnotetext{
${ }^{174}$ Para detalhes conferir: CHAVES, Francisco Eduardo Carrilho. Controle externo da gestão pública: a fiscalização pelo Legislativo e pelos Tribunais de Contas. $2^{\text {a }}$ tiragem. Niterói: Impetus, 2007. pp. 10-13.

${ }^{175}$ BUGARIN, Paulo Soares. Op. cit. p. 48.

${ }^{176}$ CHAVES, Francisco Eduardo Carrilho. Op. cit. p. 11.

177 Sobre o tema profere Francisco Eduardo Carrilho Chaves: "Estas [as Controladorias Gerais], como não detêm poder judicante, têm nos seus relatórios de auditoria os resultados finais dos seus trabalhos, que podem vir a ser apreciados pelos respectivos parlamentos". Idem. Ibidem.

${ }^{178}$ Idem. p. 12.
} 
processo de elaboração da peça técnica - parecer - referente à Conta Geral do Estado e posterior apreciação e votação da Assembleia da República, quando então será exercida a fiscalização política.

\subsubsection{O modelo italiano}

A Corte dei Conti italiana está prevista nos artigos $100, \S 2^{\mathrm{o}^{179}} \mathrm{e}$ $103, \S 2^{\mathrm{o}^{180}}$ da Constituição da República e realiza um controle prévio sobre os atos do Governo e um controle "a posteriori" sobre a gestão financeira do Estado, fazendo este último, pelo processo da prestação de contas geral.

Os membros da Corte de Contas são juízes. O Tribunal é composto pelo Presidente, Procurador-Geral, presidentes de seção, conselheiros, primeiros referendários e referendários. Os juízes são escolhidos por concurso público, apreciação de currículos e provas. Podem participar do concurso: "os magistrados judiciais com o grau de juiz de direito, advogados, directores gerais com pelo menos cinco de serviço público". ${ }^{181}$ A eles são garantidos um regime estatutário semelhante ao dos magistrados judiciais e a inamovibilidade.

Os Conselheiros, no entanto, podem ser pessoas estranhas à magistratura, sendo nomeados pelo Governo Italiano, por força do artigo 7 do Texto Único 1.214 , de 12 de julho de $1934 .^{182}$

No que tange ao controle prévio, materializa-se através do visto ou do veto da despesa. O primeiro é conferido quando a despesa é legítima e o veto da Corte de Contas, que pode ser parcial ou total, suspende (no veto parcial) a realização de

\footnotetext{
179 “Art. 100, $\S 2^{\circ}$. La Corte dei conti esercita il controllo preventivo di legittimità sugli atti del Governo, e anche quello successivo sulla gestione del bilancio dello Stato. Partecipa, nei casi e nelle forme stabilite dalla legge, al controllo sulla gestione finanziaria degli enti a cui lo Stato contribuisce in via ordinaria. Riferisce direttamente alle Camere sul risultato del riscontro eseguito". Costituzione della Repubblica Italiana. "A Corte de Contas realiza o controle preventivo sobre os atos do Governo e, também, o controle posterior sobre a gestão orçamentária do Estado. Participa, nos casos e nas formas estabelecidas pelas leis, do controle sobre a gestão financeira dos entes aos quais o Estado contribui ordinariamente. Remete-se diretamente à Câmara sobre o resultado das verificações encontradas". (tradução nossa). Disponível em: <http://www.senato.it/documenti/repository/costituzione.pdf>, acesso em 26 de nov. 2011.

180 "Art. $103, \S 2^{\circ}$. La Corte dei conti há giurisdizione nelle materie della contabilità publica e nelle altre specificate dalla legge". Costituzione della Repubblica Italiana. "A Corte de Contas tem jurisdição nas matérias de contabilidade pública e nas outras especificadas nas leis". (tradução nossa). Disponível em: <http://www.senato.it/documenti/repository/costituzione.pdf>, acesso em 26 de nov. 2011.

${ }^{181}$ [s. n.]. Tribunais de Contas e instituições congêneres em diferentes países. Gabinete do Conselheiro Presidente. Lisboa: 1992. p. 228.

${ }^{182}$ Para detalhes, consultar: GUALAZZI, Eduardo Lobo Botelho. Op. cit. pp. 78-79.
} 
despesas ou impede (no veto absoluto) que o Poder Executivo as realize, sendo comum o veto nos casos de falta de verba ou nas situações em que a verba foi arrecadada de maneira imprópria.

Quanto ao controle posterior, ocorre sobre a prestação de contas anual do Estado, que é encaminhada à Corte pelo Ministério do Tesouro e que se refere às receitas e às despesas do Governo. Ela é debatida na Corte e, posteriormente, encaminhada ao Parlamento.

Constitui, a Corte de Contas italiana, um órgão auxiliar ${ }^{183}$ do Estado (e não do Governo) da República Italiana. Esta diferença - órgão do Estado e não do Governo - é deveras importante. Reflete a independência da Corte de Contas no exercício de suas funções. Bem profere Eduardo Lobo Botelho Gualazzi sobre o fato de ser a Corte de Contas órgão auxiliar:

"Destarte, a virtual unanimidade da doutrina italiana atribui à Corte de Contas da Itália os seguintes característicos: a) órgão de relevo constitucional - trata-se de órgão auxiliar do Estado, não do Governo, aspecto expresso e nítido nos Relatórios da Assembléia Constituinte da República Italiana, de 1946/1947, de que resultou a Constituição da República Italiana, de 27 de dezembro de 1947, vigente nos dias atuais; (...)"184

Sobre a ausência de subordinação entre a Corte de Contas e o Poder Executivo e, pois, acerca da independência da primeira, profere Enrico Spagna Musso:

\footnotetext{
"Seja a Corte de Contas seja o Conselho de Estado pela natureza e delicadeza das funções que exercem, necessitam de uma posição de independência em particular com relação ao Governo, razão pela qual o 'auxílio' não deve significar subordinação nem confrontos com qualquer órgão. Não são órgãos constitucionais porque a existência deles não influencia de maneira determinante sobre a forma de governo, mas o relevo constitucional impõe igualmente uma garantia de independência; não por acaso o último parágrafo do artigo 100 da Constituição Italiana declara que a lei assegura a independência destes
}

\footnotetext{
${ }^{183}$ De acordo com Eduardo Lobo Botelho Gualazzi, a Corte de Contas é composta pelo "Presidente do Conselho e pelos Ministros, conjunto que forma o Conselho dos Ministros, sob forma de governo parlamentarista. Portanto, a Corte de Contas da Itália é um dos 'órgãos auxiliares' do Poder Executivo (Conselho de Ministros) da Itália (...).Idem. p. 87.

${ }^{184}$ Idem. p. 118.
} 
dois institutos [a Corte de Contas e o Conselho de Estado] e dos seus componentes em relação ao Governo". ${ }^{185}$ (grifos e tradução nossos)

Como se verifica, o fato de ser órgão auxiliar do Estado, não significa que haja subordinação entre este e a Corte de Contas, sob pena de a fiscalização orçamentária desta última não poder ser executada com imparcialidade.

Ressalte-se, ademais, que as decisões da Corte de Contas devem ser encaminhadas ao Poder Legislativo sem que por isso se possa afirmar, mais uma vez, haver subordinação entre estes dois entes.

A Corte de Contas é, ainda, a titular da jurisdição em matéria de contabilidade pública e emite juízo técnico de conformidade ou de não conformidade das contas, sendo que o resultado da atividade de controle deverá ser encaminhado ao Parlamento. Destaca, no entanto, Eduardo Lobo Botelho Gualazzi, que a Corte de Contas não exerce jurisdição em sentido estrito. Firma seu posicionamento interpretando a parte final do artigo 111 da Constituição Italiana, segundo o qual:

"pode-se afirmar conclusivamente que a Corte de Contas da Itália não exerce jurisdição em sentido estrito, não é poder jurisdicional, não é Poder Judiciário, sequer sob aspecto material, objetivo, porque suas decisões finais podem ser objeto de revisão no âmbito do Poder Judiciário italiano, nos casos em que o ordenamento jurídico daquele Estado soberano admite acesso ao Poder Judiciário. em suma, a Corte de Contas da Itália não integra, formal ou substancialmente, o Poder Judiciário (civil e penal) daquele País, embora exerça algumas competências do 'contencioso administrativo' da Itália”. ${ }^{186}$

Contradizendo o autor precitado, Odete Medauar assevera que, no que se refere ao controle posterior, a Corte de Contas exerce função jurisdicional, tratandose, na espécie, de "jurisdição administrativa especial". Cita a autora, para corroborar este entendimento, exemplos de funções jurisdicionais, dentre as quais, "a prestação de contas dos agentes contábeis, aí incluídos todos os que recebem dinheiro do Estado a fim de

\footnotetext{
185 Sia la corte dei conti che il consiglio di Stato per la natura e delicatezza delle funzioni esercitate necessitano di una posizione di indipendenza in particolare nei riguardi del governo, ragion per cui la loro 'ausiliarietà' non deve significare subordinazione nei confronti di alcun organo. Non sono organi costituzionali perché la loro esistenza non incide in maniera determinante sulla forma di governo, ma Il loro rilievo costituzionale impone ugualmente una garanzia di indipendenza; non a caso, dunque, l'ultimo comma dell'art. 100, const. dichiara che la legge assicura l'indipendenza dei due stituti e dei loro componenti nei riguardi del governo". MUSSO, Enrico Spagna. Diritto costituzionale. II ed. Padova: CEDAM - Casa Editrice Dott. Antonio Milani, 1986. p. 655.

${ }^{186}$ GUALAZZI, Eduardo Lobo Botelho. Op. cit. p. 89
} 
realizar pagamentos por conta deste" 187 e a questão referente à "responsabilidade contábil e patrimonial dos agentes públicos". ${ }^{188}$

\subsubsection{O modelo francês}

A Cour des Comptes (Corte de Contas) francesa existe desde a Idade Média e, atualmente, está prevista no artigo 47-2, da Constituição Francesa de 1958 que dispõe que "A Corte de Contas assiste o Parlamento no controle da ação do Governo". ${ }^{189}$ Isto não significa que exista subordinação entre o Parlamento e a Corte de Contas. A independência da Instituição deriva da sua jurisdição, da inamovibilidade que é garantida aos seus membros e do seu programa de controle.

Não há que se falar, ainda, consoante Odete Medauar e diferentemente do que ocorre na Itália, em papel auxiliar da Corte de Contas. A autora citada ensina que:

\footnotetext{
"Em termos institucionais, embora figure na Constituição no título referente às 'Relações entre o Parlamento e o Governo', apresenta-se como órgão jurisdicional, independente de qualquer Poder, não se mencionando na doutrina eventual condição de auxiliar quer do Legislativo quer do Executivo". ${ }^{190}$ (grifos nossos)
}

Não é este o entendimento de Eduardo Lobo Botelho Gualazzi, para o qual a Corte de Contas funciona como "assistente" do Parlamento, competindo-lhe controlar todas as contas do Estado, atuando em três áreas específicas: “a) elaboração do

\footnotetext{
${ }^{187}$ MEDAUAR, Odete. Controle da administração pública pelo Tribunal de Contas. Revista de Informação Legislativa. Ano 27, n. 108. Brasília: out./dez., 1990. p. 106.

${ }^{188}$ Idem. Ibidem.

189 “Art. 47-2. A Corte de Contas assiste o Parlamento no controle da ação do Governo. Assiste o Parlamento e o Governo no controle da execução das leis de finanças e de aplicação das leis de financiamento da seguridade social assim como na avaliação das políticas públicas. Através de seus relatórios públicos, contribui para a informação dos cidadãos. As contas das administrações públicas são conformes às leis e verdadeiras. Elas dão uma imagem fiel do resultado de sua gestão, de seu patrimônio e de sua situação financeira". (tradução nossa). "La Cour des comptes assiste le Parlement dans le contrôle de l'action du Gouvernement. Elle assiste le Parlement et le Gouvernement dans le contrôle de l'exécution des lois de finances et de l'application des lois de financement de la sécurité sociale ainsi que dans l'évaluation des politiques publiques. Par ses rapports publics, elle contribue à l'information des citoyens. Les comptes des administrations publiques sont réguliers et sincères. Ils donnent une image fidèle du résultat de leur gestion, de leur patrimoine et de leur situation financière". Constitucion du 4 de octobre de 1958. Disponível em: <http://www.conseil-constitutionnel.fr/conseil-constitutionnel/francais/la-constitution/la-constitution-du-4octobre-1958/texte-integral-de-la-constitution-de-1958.5074.html\#titre5>, acesso em 27 de nov. 2011.

${ }^{190}$ MEDAUAR, Odete. Controle da administração pública pelo Tribunal de Contas. Revista de Informação Legislativa. Ano 27, n. 108. Brasília: out./dez., 1990. p. 112.
} 
orçamento das Assembléias ${ }^{191}$; b) elaboração e controle do orçamento do Estado; c) controle sobre as empresas públicas". ${ }^{192}$

A Corte é composta por magistrados distribuídos entre Primeiro Presidente, Presidentes de Câmara, Conselheiros Mestres, Conselheiros Referendários e Auditores, sendo o Primeiro Presidente nomeado pelo Presidente da República e escolhido entre magistrados do Tribunal ou de fora dele, "entre pessoas que satisfaçam as condições gerais de ingresso na função pública, sob proposta do Governo". ${ }^{193}$ Os demais membros são nomeados pelo Presidente da República. Conta, ainda, com um Ministério Público especializado, que atua no ramo do controle dos gastos públicos, que não é parte integrante da Corte de Contas, mas age para que a lei seja aplicada.

A Corte de Contas francesa insere-se na justiça administrativa e funciona como a "principal jurisdição administrativa especializada da França"194 podendo, suas decisões, assim como as decisões dos Tribunais Administrativos, ser revistas pelo Conselho do Estado. Consoante afirma Julio Cesar Manhães de Araujo, a Corte de Contas francesa exerce jurisdição ${ }^{195}$, ou seja, diz o direito no caso concreto.

Os acórdãos da Corte de Contas podem impor a responsabilidade pessoal e pecuniária do gestor público; determinar a restituição aos cofres públicos das quantias indevidamente utilizadas; condenar ao pagamento de multas em caso de atraso da elaboração das contas ou de respostas às injunções. ${ }^{196}$

191 Questão interessante diz respeito à participação da Corte de Contas na elaboração do orçamento das Assembleias. Preleciona Eduardo Lobo Botelho Gualazzi: “O art. 7 do decreto de 17 de novembro de 1958 estabelece as regras atinentes à fixação do orçamento das Assembléias. Os créditos indispensáveis ao funcionamento das Assembléias parlamentares são propostos pelos questores de cada Assembléia e acertados por uma comissão de questores de duas Assembléias: esta comissão delibera sob a presidência de um Presidente de Câmara da Corte de Contas, designado pelo Primeiro Presidente desta Corte. Dois Magistrados da Corte de Contas assistem a referida comissão, exercendo função consultiva. As proposições orçamentárias, resultantes das deliberações dessa comissão, são inscritas no projeto de lei orçamentária". GUALAZZI, Eduardo Lobo Botelho. Op. cit. p. 68.

${ }^{192}$ Idem. Ibidem.

193 [s. n.]. Tribunais de Contas e instituições congêneres em diferentes países. Gabinete do Presidente. Lisboa: 1992. pp. 176-177.

${ }^{194}$ GUALAZZI, Eduardo Lobo Botelho. Op. cit. p. 59.

195 “"Alinha ainda, que as Sete Câmaras constituem-se nos órgãos deliberativos e jurisdicionais da Corte, asseverando que inequivocamente a Corte dispõe de função jurisdicional, no sentido de dispor de poder para dizer o direito". ARAÚJO, Julio Cesar Manhães de. Controle da atividade administrativa pelo Tribunal de Contas na Constituição de 1988. Curitiba: Juruá, 2010. p. 103.

196 Para detalhes, consultar: [s. n.]. Tribunais de Contas e instituições congêneres em diferentes países. Gabinete do Conselheiro Presidente. Lisboa: 1992. p. 180. 
A França é conhecida por realizar um controle tão somente " $a$ posteriori" das despesas públicas, havendo diferença entre os ordenadores ou autorizadores (“ordennateurs") das despesas - que "somente decidem, de acordo com a lei orçamentária, quais os pagamentos a serem efetuados"197 e os contadores (“comptables") que "apenas efetuam os pagamentos e, reflexamente, fiscalizam a atividade dos ordenadores". ${ }^{198}$ Segundo Eduardo Lobo Botelho Gualazzi, “(...) esta dicotomia entre as autoridades públicas de execução orçamentária é essencial para assegurar-se a legitimidade, a conveniência, a oportunidade, a eficiência da gestão orçamentária"199 e funciona como um sistema de controles recíprocos, pois os ordenadores da despesa fiscalizam os contadores e vice-versa.

Ademais, sobre os ordenadores da despesa recaem atribuições administrativas da Corte e sobre os controladores, atribuições de ordem jurisdicional ${ }^{200}$. Exemplos de ordenadores das despesas são os Ministros, Prefeitos, Presidentes de Câmaras. Sobre eles não incide a jurisdição da Corte de Contas. Em estudo sobre a Corte de Contas francesa, realizado pelo Gabinete do Presidente do Tribunal de Contas de Lisboa, concluiu-se:

"O Tribunal não tem jurisdição sobre os ordenadores, pelo que a gestão destes não pode ser objecto de observações tornadas públicas. Em compensação, podem por força de certas irregularidades de gestão ser levados perante o Tribunal de Disciplina Orçamental e Financeira". ${ }^{201}$

Há, ainda, além dos já citados - os ordenadores das despesas e os contadores -, os "controladores de despesas empenhadas" ("contrôleurs dês dépenses engagées"), que estão vinculados ao Ministro das Finanças e aos quais compete "verificar as condições em que o administrador decide realizar uma despesa". ${ }^{202}$ O Ministro das Finanças mantém, ainda, a Inspetoria Geral das Finanças, que realiza inspeções sobre as

\footnotetext{
${ }^{197}$ GUALAZZI, Eduardo Lobo Botelho. Op. cit. p. 60.

${ }^{198}$ Idem. Ibidem.

${ }^{199}$ Idem. Ibidem.

${ }^{200}$ Sobre as atribuições de ordem administrativa e jurisdicional, profere Julio Cesar Manhães de Araujo: "As administrativas incidem sobre os ordenadores da despesa, ou seja: sobre aqueles que mandam onerar a Fazenda, no sentido de vinculá-la a uma determinada obrigação, notadamente de índole financeira, ao passo que a jurisdicional incide sobre os contadores, que são aqueles que levam os pagamentos a efeito. ARAÚJO, Julio Cesar Manhães de. Op. cit. p. 103.

${ }^{201}$ [s. n.]. Tribunais de Contas e instituições congêneres em diferentes países. Gabinete do Conselheiro Presidente. Lisboa: 1992. p. 180.

${ }^{202}$ GUALAZZI, Eduardo Lobo Botelho. Op. cit. p. 61.
} 
atividades dos ordenadores e dos contadores, podendo, tais inspeções, ser concomitantes ou "a posteriori".

Todo este aparato - ordenadores da despesa, contadores, Ministro das Finanças e Inspetoria Geral das Finanças - está inserido na Administração Pública, no âmbito do Poder Executivo. O controle “a posteriori”, por seu turno, realizado pela Corte de Contas francesa, insere-se no âmbito do Poder Legislativo e é independente do Poder Executivo. $^{203}$

\subsubsection{O modelo belga}

A Corte de Contas belga está prevista no artigo 116 da Constituição, que determina que os membros do Tribunal - Presidentes, Conselheiros e Secretários - são nomeados pela Câmara dos Deputados para um mandato de seis anos, podendo, a qualquer tempo, ser por ela exonerados. De outra parte, o mandato pode ser renovado ilimitadamente. Os Presidentes e Conselheiros devem ter, no mínimo, trinta anos. A "instituição depende assim do poder legislativo e é independente do poder executivo". ${ }^{204}$

Não existe a figura do Ministério Público especializado, funcionando, o Conselheiro mais novo, como Promotor, competindo-lhe "elaborar uma lista geral de todos responsáveis que devem enviar as suas contas ao Tribunal". ${ }^{205}$ Também se inserem entre as obrigações do Conselheiro que atua como Ministério Público "velar pela apresentação das contas nos prazos legais e é a seu pedido que são pronunciadas as condenações pelo atraso na elaboração das contas". 206

\footnotetext{
${ }^{203}$ Esse conjunto de autoridades de execução orçamentária (autorizadores e contadores), que se controlam mutuamente, bem como as autoridades e órgão de controle específicos, remanescem todos inseridos no âmbito do Poder Executivo - Administração Pública. O controle a posteriori, global, no âmbito do Poder Legislativo, independente do Poder Executivo - Administração Pública, é atribuído exclusivamente à Corte de Contas". GUALAZZI, Eduardo Lobo Botelho. Regime jurídico dos Tribunais de Contas. São Paulo: Revista dos Tribunais, 1992. p. 61.

${ }^{204}$ [s. n.]. Tribunais de Contas e instituições congêneres em diferentes países. Gabinete do Conselheiro Presidente. Lisboa: 1992. p. 63.

${ }^{205}$ [s. n.]. Tribunais de Contas e instituições congêneres em diferentes países. Gabinete do Conselheiro Presidente. Lisboa: 1992. p. 64. Consistem funções também do Conselheiro mais novo, como Ministério Público, velar pela "apresentação das contas nos prazos legais e é a seu pedido que são pronunciadas as condenações pelo atraso na elaboração das contas".

${ }^{206}$ [s. n.]. Tribunais de Contas e instituições congêneres em diferentes países. Gabinete do Conselheiro Presidente. Lisboa: 1992. p. 64.
} 
Além disso, os funcionários da Corte de Contas são remunerados pelo Parlamento, demonstrando, com isso, a subordinação da primeira em relação ao segundo.

A Corte realiza um controle prévio sobre as questões relativas ao orçamento, significando, então, que a Corte de Contas pode utilizar o veto para impedir uma despesa. Entretanto, como o controle é prévio, o ordenador pode praticar o ato, por sua conta e risco. Neste caso, o órgão controlador (a Corte de Contas) comunica o fato ao Parlamento, para a adoção de medidas que entender cabíveis. É que, se assim não fosse, a decisão da Corte de Contas seria totalmente inútil para o controle. ${ }^{207}$

A Corte de Contas Belga exerce atribuições administrativas e jurisdicionais. Dentre as administrativas, encontram-se "a redação da prestação de contas geral do Estado, reunindo as prestações de contas dos Ministros, cada qual no âmbito de seu órgão". ${ }^{208}$ A prestação de contas geral é prévia à votação, no Parlamento, da lei de contas, "que abrange as receitas e despesas do Estado realmente realizadas durante o ano anterior; tais leis são votadas às vezes com certo atraso, o que lhes retira todo interesse". 209

A atribuição administrativa mais importante, segundo Odete Medauar, é a aposição do visto à ordem de pagamento do tesouro para os ordenadores da despesa - que na Bélgica são os Ministros responsáveis ou os seus funcionários delegados. $^{210}$

No que tange à atribuição jurisdicional, trata-se de jurisdição administrativa a que estão sujeitos todos os contadores do tesouro e das províncias, os quais, ao final de seus mandatos, devem prestar contas de seus atos e têm suas contas aprovadas ou rejeitadas. Se aprovadas, os contadores são desobrigados e, se rejeitadas, devem recolher a importância que não foi aprovada.

Além disso, a cada primeiro de julho o Ministro das Finanças deve encaminhar às Câmaras e à Corte de Contas a prestação de contas geral do Estado. Sobre ela, assevera Eduardo Lobo Botelho Gualazzi:

\footnotetext{
${ }^{207}$ Para detalhes, conferir: ARAÚJO, Julio Cesar Manhães de. Op. cit. p. 105.

${ }^{208}$ MEDAUAR, Odete. Controle da administração pública pelo Tribunal de Contas. Revista de Informação Legislativa. Ano 27, n. 108. Brasília: out./dez., 1990. p. 109.

${ }^{209}$ Idem. Ibidem.

${ }^{210}$ Idem. Ibidem.
} 
"O Ministro das Finanças encaminha, em $1^{\circ}$ de julho de cada ano, às Câmaras e à Corte de Contas belga, a prestação de contas geral do Estado, que compreende a conta do orçamento, a conta de tesouraria e a conta dos diversos serviços públicos e especiais; nenhum poder, todavia tem a Corte para fazer respeitar esta data-limite. Até 30 de setembro de cada ano, a Corte transmite às Câmaras a prestação de contas geral, com suas próprias observações; na mesma ocasião, são apresentados o projeto de lei de aprovação do resumo da prestação geral de contas, assim como o projeto de orçamento relativo ao ano sucessivo". ${ }^{211}$

Há, ainda, previsão de visto com reserva, porém não do visto com recusa absoluta de registro. Assim, os motivos da recusa devem ser encaminhados ao Parlamento para que, realizando o juízo político, decida a questão. Nas palavras de Eduardo Lobo Botelho Gualazzi:

"No âmbito da Corte de Contas belga, é prevista a aposição de visto com reserva, mediante procedimento análogo àquele previsto para a Corte de Contas da Itália; porém, não há previsão de casos de recusa absoluta de registro: a denúncia ao Parlamento sobre os motivos de recusa advém imediatamente, para o subsequiente juízo político sobre as operações contábeis do Governo". ${ }^{212}$ (grifos nossos)

Mostram-se, aqui, mais próximas as instituições constituídas pela Corte de Contas e pelo Parlamento, tal como ocorre no Brasil.

\subsubsection{O modelo português}

O controle financeiro é matéria antiga em Portugal. Já no século XIII foi criada a Casa dos Contos, com o intuito de controlar os gastos públicos, embora houvesse, naquele momento, dependência desta em relação aos órgãos que detinham a decisão política. É, no entanto, o ano de 1849 que traz inovações na questão financeira, com a criação do Tribunal de Contas, que "assinala o nascimento do controlo financeiro externo e independente em Portugal". ${ }^{213}$

Atualmente, o Tribunal de Contas integra o Poder Judiciário e tem status de órgão constitucional. Está previsto no artigo 214 da Constituição Portuguesa, que

\footnotetext{
${ }^{211}$ GUALAZZI, Eduardo Lobo Botelho. Op. cit. p. 124.

212 Idem. Ibidem.

${ }^{213}$ SOUSA, Alfredo José. O Tribunal de Contas de Portugal na actualidade. In: SOUSA, Alfredo José et al. O novo Tribunal de Contas: órgão protetor dos direitos fundamentais. $3^{\text {a }}$ ed. rev. e ampl. Belo Horizonte: Fórum, 2005. p. 18.
} 
estabelece: “1. O Tribunal de Contas é o órgão supremo de fiscalização da legalidade das despesas públicas e de julgamento das contas que a lei mandar submeter-lhe, competindolhe, nomeadamente: (...)"214. Dentre tais competências encontram-se dar parecer sobre a Conta Geral do Estado, incluindo a da segurança social, e responsabilizar os agentes por infrações financeiras, na forma da lei. ${ }^{215}$

No que tange à Conta Geral do Estado, em similitude com o modelo brasileiro, dispõe o artigo $107^{\circ}$ da Constituição da República Portuguesa:

“A execução do Orçamento será fiscalizada pelo Tribunal de Contas e pela Assembleia da República, que, precedendo parecer daquele tribunal, apreciará e aprovará a Conta Geral do Estado, incluindo a da segurança social". ${ }^{216}$ (grifos nossos)

Vale dizer, tanto em Portugal como no Brasil, o Tribunal de Contas deve elaborar um parecer para que, no caso português, a Assembleia da República aprove ou rejeite a "Conta Geral do Estado". Trata-se de controle externo realizado tanto pela Assembleia da República quanto pelo Tribunal de Contas sobre as contas do Estado. Consoante asseveram J. J. Gomes Canotilho e Vital Moreira, pode-se ter a falsa impressão de que se trata de uma fiscalização somente posterior. Entretanto, a Assembleia da República e o Tribunal de Contas podem efetuar um controle concomitante à execução do orçamento. $^{217}$

${ }^{214}$ Constituição da República Portuguesa com a VII Revisão Constitucional de 2005. Disponível em: $\langle\mathrm{http} / / /$ www.parlamento.pt/Legislacao/Paginas/ConstituicaoRepublicaPortuguesa.aspx $>$, acesso em $28 \mathrm{de}$ nov. 2011.

${ }^{215}$ Art. 214. "1. O Tribunal de Contas é o órgão supremo de fiscalização da legalidade das despesas públicas e de julgamento das contas que a lei mandar submeter-lhe, competindo-lhe, nomeadamente: a) Dar parecer sobre a Conta Geral do Estado, incluindo a da segurança social; b) Dar parecer sobre as contas das Regiões Autónomas dos Açores e da Madeira; c) Efectivar a responsabilidade por infracções financeiras, nos termos da lei; d) Exercer as demais competências que lhe forem atribuídas por lei. Constituição da República Portuguesa com a VII Revisão Constitucional de 2005. Disponível em: 〈http://www.parlamento.pt/Legislacao/Paginas/ConstituicaoRepublicaPortuguesa.aspx >, acesso em $28 \mathrm{de}$ nov. 2011.

${ }^{216}$ Constituição da República Portuguesa com a VII Revisão Constitucional de 2005. Disponível em: < http://www.parlamento.pt/Legislacao/Paginas/ConstituicaoRepublicaPortuguesa.aspx>, acesso em 28 de nov. 2011.

${ }^{217}$ Asseveram J. J. Gomes Canotilho e Vital Moreira que: "A fiscalização da execução orçamental pode e deve ser efectuada concomitantemente com execução ela mesma, durante o exercício orçamental. A AR [Assembleia da República] pode fazê-lo ao abrigo do seu poder geral de fiscalizar os actos do Governo e da Administração (art. 162\%); o Tribunal de contas pode ser munido de idênticos poderes de fiscalização concomitante, pela sua lei orgânica. De resto, nada impede a cooperação da AR [Assembleia da República] e do Tribunal de Contas nessa tarefa". CANOTILHO, J. J. Gomes; MOREIRA, Vital. Constituição da 
No tocante ao controle da matéria orçamentária, tem o Tribunal de Contas atuação sob três diferentes enfoques: monitora a execução orçamentária; fiscaliza a regularidade das despesas públicas; e elabora parecer sobre as contas do Estado sendo, este, "tanto sob o ponto de vista da legalidade como sob o ponto de vista da sua economia, eficácia e eficiência". ${ }^{218}$

A participação da Assembleia da República na matéria orçamentária é diferente. Compete a ela a "fiscalização política da execução orçamental" 219 e exerce tal atividade quando fiscaliza a ação governamental ou quando aprecia e vota a conta geral do Estado. Sobre esta última hipótese advertem J. J. Gomes Canotilho e Vidal Moreira:

\footnotetext{
“A AR [Assembleia da República] só pode apreciar a Conta após o parecer do Tribunal, mas o Governo é obrigado a apresentar-lha, independentemente do parecer daquele, até ao último dia do ano subseqüente àquele a que ela respeita (art. $\left.162^{\circ} / \mathrm{d}\right)$ ". ${ }^{220}$
}

Semelhante ao modelo brasileiro é o fato de a Assembleia da República só poder apreciar e votar a conta do Estado após a elaboração de parecer pelo Tribunal de Contas que, dessa forma, é prévio.

Outra similitude diz respeito ao fato de que a Assembleia da República não precisa concordar com o parecer prévio do Tribunal de Contas, que aprovou ou rejeitou a conta e isto porque o parecer constitui uma peça técnica, que é encaminhada à Assembleia da República e não uma atividade jurisdicional. Consoante asseveram J. J. Gomes Canotilho e Vital Moreira:

“A AR [Assembleia da República] não tem de seguir o parecer do Tribunal de Contas, quanto à aprovação ou rejeição das contas, podendo divergir da posição daquele, visto não se tratar de um acto jurisdicional que se imponha à AR [Assembleia da República], mas sim de um parecer "técnico",.221 (grifos nossos)

República Portuguesa Anotada. v. I. São Paulo: Revista dos Tribunais; Coimbra: Coimbra Editora, 2007. p. 1121.

${ }^{218}$ Idem. p. 1122.

${ }^{219}$ Idem. Ibidem.

${ }^{220}$ Idem. Ibidem.

${ }^{221}$ Idem. Ibidem. 
Ressalte-se, ademais, que a Assembleia da República pode confirmar o parecer técnico elaborado pelo Tribunal de Contas que concluir pela rejeição da conta do Estado - tal como ocorre no Brasil - mas, como aqui, consoante proferem J. J. Gomes Canotilho e Vital Moreira: "a Constituição é omissa quanto as conseqüências de uma eventual não aprovação da conta, podendo justificar a apresentação de uma moção de censura". 222 (grifos nossos)

Apesar das similitudes apresentadas entre os sistemas, não podemos nos esquecer que o Tribunal de Contas português integra o Poder Judiciário, enquanto o Brasileiro está inserido, de acordo com a Constituição, na Seção IX - "Da Fiscalização Contábil, Financeira e Orçamentária" - no bojo do Capítulo I - "Do Poder Legislativo" - insertos, ambos, no Título IV - "Da Organização dos Poderes".

De outra parte, os juízes do Tribunal de Contas português têm as mesmas garantias que são conferidas aos juízes do Supremo Tribunal de Justiça daquele país. O mandato é vitalício cessando, no entanto, aos setenta anos de idade do juiz. O Tribunal é composto por um Presidente, cujo mandato é de quatro anos, nomeado e exonerado pelo Presidente da República, com o aval do Governo. Os juízes, por sua vez, são nomeados pelo Presidente do Tribunal, sendo recrutados por concurso curricular público. ${ }^{223}$ Conta, ainda, com Ministério Público, representado pelo Procurador-Geral da República. Já nas Secções Regionais, o Procurador-Geral da República indica um magistrado que representa o Ministério Público. ${ }^{224}$ Ao Ministério Público competem, uma vez verificadas infrações financeiras pelo Tribunal de Contas, os processos de apuração de responsabilidades e a aplicação de multas.

\footnotetext{
222 Idem. Ibidem.

${ }^{223}$ Podem participar do concurso as pessoas com mais de trinta e cinco anos de idade, que preencham os requisitos da Lei para nomeação dos funcionários do Estado e que se encontrem em uma das seguintes condições: “a) doutores em Direito, Economia, Finanças ou Organização e Gestão; b) mestres ou licenciados em Direito, Economia, Finanças ou Organização e Gestão, com pelo menos dez anos de serviço na Administração Pública e classificação de 'muito bom', sendo três daqueles anos no exercício de funções dirigentes ao nível do cago de director-geral ou equiparado ou de funções docentes no ensino superior universitário em disciplinas afins da matéria do Tribunal de Contas; c) mestres ou licenciados em Direito, Economia, Finanças ou Organização ou Gestão de empresas, de reconhecido mérito com pelo menos dez anos de serviço em cargos de direçção de empresas e três como membro de conselhos de administração ou de gestão ou de conselhos fiscais ou de comissões de fiscalização e; d) magistrados judiciais dos Tribunais Administrativos e Fiscais ou do Ministério Público, com pelo menos dez anos na respectiva magistratura e classificação superior a 'bom"”. [s. n.]. Tribunais de Contas e instituições congêneres em diferentes países. Gabinete do Conselheiro Presidente. Lisboa: 1992. p. 295. Além disso, quem decide sobre os vencedores é um júri independente.

224 “O Ministério Público é representado pelo magistrado para o efeito designado pelo Procurador-Geral da República, o qual é substituído nas suas faltas e impedimentos, pelo seu substituto geral (artigo $47^{\circ}, \mathrm{n}^{\circ} 2$, da Lei no 86/89)”. [s. n.]. Tribunais de Contas e instituições congêneres em diferentes países. Idem. p. 296.
} 
Além da nomeação dos juízes pelo Presidente do Tribunal de Contas, outras medidas foram tomadas para que se garanta a independência da Corte, que se materializaram na Lei $n^{\circ} 86 / 89^{225}$, conhecida como a primeira parte da Reforma do Tribunal de Contas de Portugal. Entre essas medidas destacam-se: 1) os "Serviços de Apoio" se desvincularam do Ministério das Finanças e "passaram a depender funcionalmente do Tribunal e administrativamente de seu Presidente"226; 2) O Presidente passou a ter os mesmos poderes que os Ministros quanto "à superintendência e gestão dos Serviços de Apoio" ${ }^{227} ; 3$ ) "reduziu-se o âmbito material da fiscalização 'a priori’ aos actos de pessoal e aos contratos de maior relevância financeira embora alargando o seu âmbito subjectivo às autarquias locais" 228 ; 4) tornou-se possível a seleção anual das contas que deveriam ser submetidas ao Tribunal, para o respectivo julgamento; 5) admitiu a realização de auditorias nas contas para verificar a legalidade das despesas realizadas; e 6) com a inserção de Portugal na Comunidade Europeia, garantiu-se ao Tribunal de Contas "a fiscalização da aplicação dos recursos financeiros comunitários e a possibilidade de cooperação com o Tribunal de Contas Europeu". 229

Mais tarde, entrou em vigor a Lei $\mathrm{n}^{\circ} 98 / 97^{230}$, de 26 de agosto, conhecida como a segunda parte da Reforma do Tribunal de Contas. Dentre as inovações introduzidas, que valem até hoje, estão: 1) a arrecadação própria do Tribunal de Contas que, "conjugado com as receitas provindas do Orçamento Geral do Estado consubstancia a sua autonomia financeira e reforçam a sua independência"231; 2) as contas dos gestores públicos podem ser submetidas a julgamento e resultar na sua responsabilização financeira; 3) o Tribunal tem competência para determinar a realização de auditorias que incidem sobre a legalidade dos atos e, também, sobre a boa gestão financeira, esta relativa à economia, à eficácia e à eficiência dos atos; 4) a possibilidade de o Tribunal aprovar pareceres sobre projetos legislativos em matéria financeira, quando solicitado pela Assembleia da República ou pelo Governo ${ }^{232}$; 5) a presença do Presidente ou dos relatores

\footnotetext{
${ }^{225}$ Idem. pp. 20-21.

${ }^{226}$ Idem. p. 20

${ }^{227}$ Idem. Ibidem.

${ }^{228}$ Idem. Ibidem.

${ }^{229}$ Idem. p. 21.

${ }^{230}$ Idem. pp. 21-24.

${ }^{231}$ Idem. p. 22.

232 "Seguindo a sistematização da própria Lei no 98/97 e começando pelas inovações nos conteúdos de competência, em traços muito essenciais as inovações introduzidas são as seguintes: à solicitação da Assembleia da República ou do Governo o tribunal pode aprovar pareceres sobre projectos legislativos em matéria financeira $\left(\operatorname{art}^{\circ} 5^{\circ} \mathrm{n}^{\mathrm{o}} 2\right)^{\prime}$. Idem. p. 23.
} 
das auditorias em comissões parlamentares, para prestarem informações; 6) a possibilidade de, no parecer do Tribunal, serem realizadas recomendações à Assembleia da República ou ao Governo, com o intuito de serem supridas as deficiências de gestão orçamentária, de organização ou de funcionamento dos serviços encontradas. ${ }^{233}$

A Lei $n^{\circ} 98 / 97^{234}$ trouxe, ainda, outra novidade: a separação entre os poderes de controle financeiro e de jurisdição. Decorre, o primeiro, "de verificação interna de contas, de verificação externa de contas através de auditorias, e de auditorias independentemente das contas de gerência" ${ }^{\text {235; }}$ o segundo, de seu turno, consiste na apuração das responsabilidades financeiras após o julgamento das contas e, também, na aplicação de sanções em processo autônomo do julgamento das contas.

Após discorrermos sobre o dever de o gestor público prestar contas e acerca dos sistemas de controle e de suas características no ordenamento estrangeiro partimos, no Capítulo seguinte, para o estudo do sistema de controle das contas públicas existente no Brasil, que se faz por meio do Tribunal de Contas e da Câmara Municipal. Traremos seus aspectos mais importantes e, em seguida, abordaremos os vários tipos de controle do poder existente no ordenamento brasileiro, dentre os quais o controle externo e o controle técnico.

\footnotetext{
233 "Seguindo a sistematização da própria Lei $\mathrm{n}^{\circ}$ 98/97 e começando pelas inovações nos conteúdos de competência, em traços muito essenciais as inovações introduzidas são as seguintes: a possibiliade de no parecer da Conta Geral do Estado se formularem recomendações à Assembleia da República ou ao Governo em ordem a serem supridas as deficiências de gestão orçamental ou de organização e funcionamento dos serviços $\left(\operatorname{art}^{\circ} 41 \mathrm{n}^{\circ} 3\right)$ ". Idem. p. 24.

${ }^{234}$ Idem. pp. 21-24.

235 Idem. p. 25.
} 


\section{CAPÍTULO III: O CONTROLE DO PODER NO ORDENAMENTO BRASILEIRO. TIPOS.}

\subsection{A "Entidade de Fiscalização Superior" brasileira: o Tribunal de Contas}

O Brasil adota o sistema de controle exercido pelo Tribunal de Contas, formado por um órgão colegiado, que possui a missão técnica de, sob a égide da Constituição Federal de 1988, realizar o controle dos gastos públicos segundo os mecanismos da legalidade, legitimidade e economicidade.

Não obstante, o Tribunal de Contas é antigo no ordenamento pátrio. Existe desde 1890 quando, por meio do Decreto nº 966-A, durante o Governo Provisório que antecedeu à Constituição de 1891, atendendo a uma proposta de Ruy Barbosa, foi ele inserido em sede constitucional.

Ruy Barbosa relata que esta Constituição, que estava por vir, tinha o escopo de alicerçar no país os institutos democráticos, já que se tratava de substituir o Império e suas leis pela República e democracia. Para o atingimento dos ideais democráticos, tornava-se necessário cuidar, também, de um outro assunto: o orçamento público. O desejo era transformá-lo em uma "instituição inviolável e soberana" ${ }^{236}$, de modo que a lei orçamentária, uma vez aprovada pelos representantes do povo, fosse totalmente fiscalizada, no seu aspecto técnico. Este trabalho deveria ser feito pelo Tribunal de Contas. Aduzia, ainda, Ruy Barbosa, a necessidade de que o novo governo constitucional fosse pautado pela estabilidade orçamentária ensinando que:

"O primeiro dos requisitos para a estabilidade de qualquer fórma de Governo constitucional está em que o orçamento deixe de ser uma simples combinação especiosa como mais ou menos tem sido, sempre,

\footnotetext{
236 BARBOSA, Ruy. Commentarios á Constituição Federal Brasileira. . v. VI: art. 72 (conclusão) a 91 (Disposições Geraes) e Disposições Transitorias.São Paulo: Livraria Acadêmica, Saraiva, 1934. p. 425. Sobre o orçamento público, proferiu o Mestre: "Refiro-me á necessidade de tornar o orçamento uma instituição inviolável e soberana, em sua missão de prover ás necessidades publicas mediante o menor sacrificio dos contribuintes, á necessidade urgente de fazer dessa lei das leis uma força da nação, um systema sabio, economico, escudado contra todos os desvios, todas as vontades, todos os poderes, que ousem perturbar-lhe o curso normal". Idem. Ibidem.
} 
entre nós, e revista o caracter de realidade segura, solemne, inaccessivel a transgressões impunes" ${ }^{237}$ (grifos nossos)

Sobre estes alicerces criou-se o Tribunal de Contas como:

“(...) corpo de magistratura intermediaria á administração e á legislatura, que, collocado em posição autonoma, com attribuições de revisão e julgamento, cercado de garantias contra quaesquer ameaças, possa exercer as suas funcções vitaes no organismo constitucional, sem risco de converter-se em instituição de ornato apparatoso e inutil". ${ }^{238}$ (grifos nossos)

Na mesma linha, Manoel Gonçalves Ferreira Filho, explicando a lição de Ruy Barbosa, assevera que o Tribunal de Contas foi criado para:

“(...) servir de instrumento para o controle financeiro e orçamentário do Legislativo sobre o Executivo. É intermediário entre um e outro, mas no sentido de que é canal necessário para a fiscalização do Legislativo sobre o Executivo. É auxiliar de um e outro no sentido de que auxilia o Legislativo a fiscalizar o Executivo e o Executivo a bem cumprir a lei". ${ }^{239}$ (grifos nossos)

Como se vê, o Tribunal de Contas, desde a sua criação, teve a autonomia como uma de suas características. A ele competia, ainda, consoante o Decreto n ${ }^{\circ}$ 966-A, realizar o controle financeiro dos gastos públicos. Isto à época da Constituição de 1891

No ordenamento constitucional de 1988, o Tribunal de Contas apresenta-se como órgão igualmente técnico, ao qual compete, em ampliação à sua origem remota, a fiscalização contábil, financeira, orçamentária, operacional e patrimonial e que, juntamente com o Poder Legislativo, é responsável pelo controle externo das contas públicas.

\footnotetext{
${ }^{237}$ Idem. p. 426.

${ }^{238}$ Idem. p. 427.

${ }^{239}$ FERREIRA FILHO, Manoel Gonçalves. Comentários à Constituição Brasileira de 1988. $3^{\mathrm{a}}$ ed. atual. v. 1 (arts. $1^{\circ}$ a 103). São Paulo: Saraiva, 2000. p. 420.
} 


\subsection{A independência e a autonomia do Tribunal de Contas brasileiro}

Verificamos, no Capítulo anterior, que as "Entidades de Fiscalização Superiores" - (EFS) ou "Instituições Supremas de Controle" - (ISC) devem ser independentes, não só do Poder Executivo, como também do Poder Legislativo, já que a independência da Instituição permite que os seus destinatários - o povo e o próprio Parlamento - recebam as informações sobre as contas públicas de maneira correta e livre de influências políticas.

Em cenário pátrio, independência e autonomia são expressões sinônimas.

O Dicionário Caldas Aulete assim define "autonomia”: "1. Situação de quem tem liberdade para pensar, decidir e agir; (...) 2. Situação de quem administra a si mesmo sem interferência externa (diz-se ger. de um país, uma instituição etc.); INDEPENDÊNCIA: a autonomia dos poderes da República. (...)". ${ }^{240} \mathrm{O}$ mesmo dicionário conceitua o vocábulo “independente” como: “1. Que está livre de sujeição, de submissão (...); 2. Que tem meios próprios de subsistência, (...); 3. Que vive sem precisar da ajuda dos outros, (...); 4. Que é politicamente autônomo, soberano (diz-se de país)",241 enquanto que "independer" vem consignado como "Não decorrer de; não estar ligado a [+ de: A liberação das verbas independe da vontade do prefeito.] "242 Também o Dicionário de Sinônimos e Antônimos conceitua as palavras independência, emancipação e autogoverno como sinônimas de "autonomia". 243

Não obstante, em Direito Constitucional e em Administrativo existe diferença entre independência e autonomia.

Independência consiste em ausência de subordinação. São independentes os três Poderes, por exemplo, tal como já afirmado no Capítulo I, não se falando em autonomia dos três Poderes e sim em independência. Caracteriza esta última o fato de os órgãos decorrerem diretamente da Constituição. Hely Lopes Meirelles traz

\footnotetext{
${ }^{240}$ AULETE, Caldas. Minidicionário contemporâneo da Língua Portuguesa. Rio de Janeiro: Nova Fronteira, 2004. p. 82.

${ }^{241}$ Idem. p. 444.

${ }^{242}$ Idem. Ibidem.

${ }^{243}$ FERNANDES, Francisco. Dicionário de Sinônimos e Antônimos da Língua Portuguesa: de acordo com a ortografia oficial brasileira. $43^{\mathrm{a}}$ ed. rev. e ampl. por Celso Luft. São Paulo: Globo, 2005. p. 131.
} 
interessante diferenciação entre eles, quando estuda os órgãos independentes e os autônomos. A explicação pode ser por nós aproveitada:

\begin{abstract}
"Órgãos independentes são os originários da Constituição e representativos dos Poderes de Estado - Legislativo, Executivo e Judiciário -, colocados no ápice da pirâmide governamental, sem qualquer subordinação hierárquica ou funcional, e só sujeitos aos controles constitucionais de um Poder pelo outro. Por isso, são também chamados órgãos primários do Estado. Esses órgãos detêm e exercem precipuamente as funções políticas, judiciais e quase-judiciais outorgadas diretamente pela Constituição, para serem desempenhadas pessoalmente por seus membros (agentes políticos, distintos de seus servidores, que são agentes administrativos), segundo normas especiais e regimentais". ${ }^{244}$ (grifos nossos)
\end{abstract}

Hely Lopes Meirelles explica serem independentes também o Ministério Público e os Tribunais de Contas da União e das demais esferas federativas, porque "participam das decisões governamentais e executam com autonomia as suas funções específicas, mas segundo diretrizes dos órgãos independentes, que expressam as ações políticas do Governo". 245

Quanto aos órgãos autônomos, aasim os define:

“(...) são os localizados na cúpula da Administração, imediatamente abaixo dos órgãos independentes e diretamente subordinados a seus chefes. Têm ampla autonomia administrativa, financeira e técnica, caracterizando-se como órgãos diretivos, com funções precípuas de planejamento, supervisão, coordenação e controle das atividades que constituem sua área de competência. Participam, das decisões governamentais e executam com autonomia as suas funções específicas, mas segundo diretrizes dos órgãos independentes, que expressam as opções políticas do Governo". ${ }^{246}$ (grifos nossos)

Desta definição extrai-se uma relação entre autonomia e independência, sendo que a primeira manifesta-se de acordo com as "diretrizes" da segunda. Socorrêmo-nos, então, dos constitucionalistas para encontrar o conceito de autonomia.

\footnotetext{
${ }^{244}$ MEIRELLES, Hely Lopes. Direito administrativo brasileiro. 31 a ed. São Paulo: Malheiros, 2005. p. 70.

${ }^{245}$ Idem. p. 71

${ }^{246}$ Idem. Ibidem.
} 
José Afonso da Silva ensina que "autonomia é a capacidade de agir dentro de círculo preestabelecido (...)" ${ }^{247}$ E continua: “é, pois, poder limitado e circunscrito e é nisso que se verifica o equilíbrio da federação, que rege as relações entre União, Estados, Distrito Federal e Municípios, todos autônomos nos termos da Constituição (art. 18)". ${ }^{248}$ (grifos nossos). Tratando do Estado federal brasileiro, assevera que essa autonomia caracteriza-se por dois elementos essenciais: "a existência de governo próprio e posse de competência exclusiva". ${ }^{249}$ Tais elementos podem ser transpostos para a seara do Tribunal de Contas, isto é, tem o Tribunal de Contas governo próprio, na medida em que possui mecanismo específico para a escolha de seus dirigentes. Trata-se de eleição que, no âmbito do Tribunal de Contas do Município de São Paulo, é realizada anualmente para escolher o Presidente, o Vice-Presidente e o Corregedor, permitida a reeleição, dela participando somente os cinco Conselheiros. Considera-se eleito o que obtiver, no mínimo, três votos. Possui, ainda, o Tribunal de Contas, competências próprias ${ }^{250}$, que são somente dele e estão previstas nos incisos II a XI do artigo 71 da Constituição Federal.

Alexandre de Moraes aduz, ainda, que a autonomia se manifesta em sua tríplice capacidade: auto-organização e normatização própria, autogoverno e autoadministração. ${ }^{251}$ Destas, o Tribunal de Contas possui o autogoverno, entendido este, no Município de São Paulo, como a capacidade de eleger, sem qualquer subordinação aos Poderes do Estado, os seus Presidente, Vice-Presidente e Corregedor. O autogoverno também se manifesta pela iniciativa do Tribunal de Contas para propor projetos de lei de matérias de sua competência ${ }^{252}$ devendo, é claro, ser aprovados pelo Legislativo e

247 SILVA, José Afonso da. Curso... Op. cit. p. 484. Este “círculo preestabelecido" é determinado pela independência entre os Poderes.

${ }^{248}$ Idem. Ibidem.

${ }^{249}$ Idem. Ibidem.

${ }^{250}$ A única exceção quanto às competências do Tribunal de Contas refere-se à sustação dos contratos, que é exclusiva do Poder Legislativo. Assim, a atribuição do Tribunal de Contas, nestes casos é, constatadas as irregularidades que maculem o contrato, comunicar ao Poder Legislativo para eventual suspensão. É o que determina o $\S 1^{\circ}$ do artigo 71, que estabelece: " $\S 1^{\circ}$. No caso de contrato, o ato de sustação será adotado diretamente pelo Congresso Nacional que solicitará, de imediato, ao Poder Executivo as medidas cabíveis". BRASIL. Constituição (1988). Constituição da República Federativa do Brasil: promulgada em 5 de outubro de 1988: atualizada até a Emenda Constitucional n ${ }^{\circ}$ 67, de 22-12-2010. 45 a ed. ampl. São Paulo: Saraiva, 2011. p. 70.

${ }^{251}$ MORAES, Alexandre de. Op. cit. p. 275. Auto-organização compreende a capacidade de os entes federativos elaborarem suas próprias Constituições e Leis Orgânicas e suas próprias leis, o que se concretiza por meio do Poder Constituinte Derivado; o autogoverno autoriza o ente a organizar o seu Executivo, Legislativo e Judiciário e a autoadministração, suas próprias competências.

${ }^{252}$ Quem confere ao Tribunal de Contas a iniciativa de projeto de lei é a própria Constituição Federal nos artigos 73, caput combinado com o 96. O primeiro dispositivo determina que o Tribunal de Contas da União pode exercer, no que couber, as atribuições previstas no artigo 96 que, por sua vez, trata da competência legislativa dos Tribunais - entre os quais se insere o de Contas -, conferindo-lhes a elaboração do regimento 
sancionados pelo Prefeito. É dizer, o Tribunal de Contas não fica na dependência do Poder Legislativo para ter a iniciativa de uma lei sobre matéria que lhe interesse e pertença. Não obstante, é verdade que a aprovação e conversão em lei dependem da anuência do Parlamento e da sanção do Prefeito, tal como qualquer lei. Possui, ainda, capacidade de autoadministração, na medida em que é detentor, como já foi explanado, de competências próprias, elencadas nos incisos do artigo 71 da Constituição Federal de 1988.

O Tribunal de Contas tem, ainda, autonomia funcional, podendo "dispor os seus recursos materiais e humanos da forma que lhe parecer mais adequada". 253

E mais. Imprescindível para o exercício das demais capacidades, é a autonomia financeira. Para alcançar esse desiderato, a proposta orçamentária é elaborada pelo próprio Tribunal e integra o projeto de lei do orçamento anual. Uma vez aprovado o projeto pelo Legislativo e sancionado pelo Chefe do Executivo, os recursos são repassados ao Tribunal, que os administra, gerencia e utiliza segundo sua conveniência e critérios adotados. Não depende, pois, dos outros Poderes para aplicar seus recursos.

Nina Beatriz Stocco Ranieri arremata trazendo um conceito genérico de autonomia:

\begin{abstract}
"No Direito, o significado mais amplo e genérico de autonomia designa poder de autodeterminação, exprimindo a idéia de direção própria. Em termos mais precisos, 'autonomia' indica a competência de autonormação, ou seja, a possibilidade de dar-se um ordenamento jurídico, o que consiste em poder funcional derivado, circunscrito ao peculiar interesse da entidade que o detém, e limitado pelo ordenamento geral em que se insere, sem o qual, ou fora do qual, não existiria. Este poder encerra conteúdo político, uma vez que ser autônomo é dispor da prerrogativa de criar direito, ainda que em áreas de competência restritas e exclusivas". ${ }^{254}$
\end{abstract}

Infere-se, do que foi exposto, que o Tribunal de Contas é dotado de autonomia, desenvolvendo funções específicas para bem desempenhar sua atividade de

interno ou a apresentação de projeto de lei para a criação de novos cargos. Por simetria, os dispositivos se aplicam no âmbito do Município equiparando-se os Tribunais de Contas ao Tribunal de Justiça. BRASIL. Constituição (1988). Constituição da República Federativa do Brasil: promulgada em 5 de outubro de 1988: atualizada até a Emenda Constitucional nº 67, de 22-12-2010. 45 a ed. ampl. São Paulo: Saraiva, 2011. p. 71 e p. 79.

${ }_{253}^{25}$ ARAÚJO, Marcos Valério de. Op. cit. p. 20.

${ }^{254}$ RANIERI, Nina Beatriz Stocco. Aspectos jurídicos da autonomia universitária no Brasil. Revista CEJ. n. 31. Brasília: out./dez., 2005. p. 20. 
controle. É, ainda, independente, não se configurando como um órgão subordinado ao Poder Legislativo. É dizer, ele é independente e autônomo, não se submetendo aos anseios do Poder Legislativo.

Reforçam nosso entendimento, quanto à ausência de subordinação do Tribunal de Contas em relação ao Poder Legislativo, os ensinamentos do Ministro do Supremo Tribunal Federal Carlos Ayres Britto:

"Diga-se mais: além de não ser órgão do Poder Legislativo, o Tribunal de Contas da União não é órgão auxiliar do Parlamento Nacional, naquele sentido de inferioridade hierárquica ou subalternidade funcional" ${ }^{255}$ (grifos nossos)

E continua:

"Como salta à evidência, é preciso medir com a trena da Constituição a estatura de certos órgãos públicos para se saber até que ponto eles se põem como instituições autônomas e o fato é que o Tribunal de Contas da União desfruta desse altaneiro status normativo da autonomia". ${ }^{256}$ (grifos nossos)

As afirmações do Ministro do Supremo Tribunal Federal, com as quais concordamos, decorrem do fato de ele assegurar que o Tribunal de Contas não compõe a estrutura interna do Congresso Nacional e isto, diz ele, a própria Constituição o autoriza a afirmar. É que o artigo 44 dispõe que "o Poder Legislativo é exercido pelo Congresso Nacional, que se compõe da Câmara dos Deputados e do Senado Federal"257 não havendo, assim, espaço para o Tribunal de Contas da União.

Ora, se não pertence ao Poder Legislativo, não pode ser a ele subordinado. Surge, então, a pergunta: pertence o Tribunal de Contas a algum Poder? Por qual razão foi inserido na Seção IX do Capítulo I da Lei Maior, que cuida do Poder Legislativo?

${ }^{255}$ BRITTO, Carlos Ayres. O regime constitucional do Tribunal de Contas. In: SOUZA, Alfredo José de... et al. O novo Tribunal de Contas: órgão protetor dos direitos fundamentais. $3^{\mathrm{a}}$ ed. rev. e ampl. Belo Horizonte: Fórum, 2005. p. 62.

${ }^{256}$ Idem. Ibidem.

${ }^{257}$ Idem. p. 54. 
À primeira indagação a resposta é negativa. O Tribunal de Contas da União não pertence à estrutura de nenhum dos Poderes. É, como se viu, órgão autônomo. Mais. É órgão constitucional autônomo porque o Tribunal de Contas da União, e os dos Estados, dos Municípios e os Conselhos de Contas têm suas formações e todas as competências - exceto uma ${ }^{258}$ - emanadas da Constituição Federal. Vale dizer, foi o Constituinte Originário que criou o Tribunal de Contas da União e lhe atribuiu suas competências, razão pela qual, mais uma vez, não há que se falar em subordinação ao Poder Legislativo. Pelo contrário, o Tribunal de Contas é autônomo e possui, como já sustentado, a capacidade de escolher seus próprios dirigentes e de apresentar projetos de lei sobre as matérias sob sua área de atuação, sendo detentor, ainda, de competências próprias.

Não sendo órgão subordinado, não se admite entendê-lo como “órgão auxiliar" do Poder Legislativo. Já tive a oportunidade de me manifestar sobre o tema:

\begin{abstract}
"Não há que se falar, portanto, como defendem alguns, que o Tribunal de Contas seria 'órgão auxiliar' do Poder Legislativo e, com isso, a ele subordinado. O entendimento da Constituição Federal é outro e, em que pese tratar-se de órgão de auxílio do Poder Legislativo, é dele independente, competindo-lhe a função de fiscalização, de modo que seus atos e decisões não podem ser alterados pelo Poder Legislativo". ${ }^{259}$
\end{abstract}

A segunda questão, quanto a saber o motivo da inserção do Tribunal em uma Seção dentro do Capítulo referente ao Poder Legislativo, é mais complexa e merece análise pormenorizada, na medida em que mantém relação com a nossa tese. Podemos, assim, adiantar uma de nossas conclusões: o fato de o Tribunal de Contas ter sido inserido na Seção IX ("Da Fiscalização Contábil, Financeira e Orçamentária”), do Capítulo I (“Do Poder Legislativo”), do Título IV (“Da Organização dos Poderes”), dá-se, pensamos, por ele realizar a fiscalização técnica - contábil, financeira, orçamentária, operacional e patrimonial - que está ligada à execução do poder financeiro, sendo este, desde os primórdios, função típica do Poder Legislativo.

\footnotetext{
${ }^{258}$ Trata-se da aplicação de sanções, que dependem de previsão em lei. É o que determina o inciso VIII do artigo 71: "aplicar aos responsáveis, em caso de ilegalidade de despesa ou irregularidade de contas, as sanções previstas em lei, que estabelecerá, entre outras cominações, multa proporcional ao dano causado ao erário". BRASIL. Constituição (1988). Constituição da República Federativa do Brasil: promulgada em 5 de outubro de 1988: atualizada até a Emenda Constitucional no 67, de 22-12-2010. $45^{\mathrm{a}}$ ed. ampl. São Paulo: Saraiva, 2011. p. 70.

${ }^{259}$ FAGUNDES, Tatiana Penharrubia. A função... Op. cit. p. 239.
} 
Pensamos, no entanto, não ser esta a melhor técnica legislativa. Para nós, o mais adequado seria colocar o Tribunal de Contas em um Capítulo específico intitulado "Dos órgãos de Cooperação", por exemplo, já que, assim, acabariam as dúvidas a respeito de ser ou não essa Corte um órgão constitucional autônomo, mas que, também nessa hipótese, realizaria a função de controle externo, constituindo mais um órgão para fiscalizar as contas do Poder Executivo.

Mais. Em nosso entender, o controle externo não é, tão somente, do Poder Legislativo, tal como prega o artigo 70, caput, da Constituição Federal. É igualmente do Tribunal de Contas, sendo que cada um tem uma atribuição específica a desempenhar: o Tribunal de Contas com a atribuição técnica e o Poder Legislativo com a política.

Podemos, agora, adiantar outra conclusão de nossa tese: para nós, a competência para a aprovação das contas municipais é compartilhada entre o Poder Legislativo e o Tribunal de Contas. Porém, ainda que se considere o Tribunal de Contas como um órgão independente do Poder Legislativo, isto não quer dizer que seja ele um órgão afastado desse Poder. Apenas significa que o Tribunal deve ter condições, no seu campo específico, de determinar quais contratos, durante o ano, deverão ser analisados, quais editais de licitação merecerão exame criterioso do Tribunal, quais controles serão concomitantes ou posteriores à realização da despesa (por exemplo, o acompanhamento, concomitante, de uma licitação da Secretaria Municipal de Educação), em que momento uma auditoria deverá ocorrer etc. Tudo isso, sem que necessite comunicar ${ }^{260}$ ao Poder Legislativo ou pedir a sua autorização. Estas características levam à conclusão de que o Tribunal de Contas é um órgão constitucional autônomo.

Reforçam nosso entendimento os ensinamentos do Ministro Marcos Vilaça:

“(...) o Parlamento, como legítimo representante dos anseios nacionais, tem incontroverso interesse nas ações do controle externo. A independência das Instituições Supremas de Controle não pode, assim, provocar seu isolamento em relação ao Poder Legislativo. Essa

\footnotetext{
${ }^{260}$ A única exceção, como dito anteriormente, que exige que o Tribunal de Contas comunique ao Poder Legislativo respectivo é a sustação de contrato. Esta competência é exclusiva do Poder Legislativo. O Tribunal de Contas pode apenas apontar as irregularidades do contrato e sugerir a sua sustação, porém, não pode suspendê-lo.
} 
independência deve apenas constituir-se na prerrogativa de que trabalhem em consonância com os interesses da representação popular - que, repise-se, devem refletir os anseios nacionais -, sempre com eles sintonizados, mas sem submissão". ${ }^{261}$ (grifos nossos)

De fato. As atribuições do Tribunal de Contas e do Poder Legislativo, em cenário pátrio, são de soma. O primeiro realiza, essencialmente, o controle técnico; o segundo, o controle político sendo, ambos, responsáveis pelo controle externo, em que pese nossa Constituição insista que o controle externo "pertença" ao Congresso Nacional.

Por outro lado, cuidando agora da eficácia das Entidades de Fiscalização Superiores, concluímos que seriam ineficazes se só se prestassem a fiscalizar as verbas públicas, sem que tivessem o poder sancionatório em relação aos maus agentes, exigindo que devolvessem as verbas mal utilizadas ou aplicando multas ou sanções disciplinares, por exemplo.

Examinadas as "Entidades de Fiscalização Superiores" ou "Instituições Supremas de Controle", das quais o Tribunal de Contas, em cenário pátrio, é exemplo passamos, no próximo tópico, a estudar as variadas classificações do poder político.

\subsection{Os tipos de controle}

Diversas são as formas existentes para a classificação do controle. Pode-se levar em consideração o órgão controlador, a sua origem, o momento em que ele é efetuado, a finalidade do controle ou a sua iniciativa, para citar apenas algumas das possibilidades. Assevera-se, ademais, que as doutrinas nacional ${ }^{262}$ e estrangeira ${ }^{263}$ partem $^{2}$

${ }^{261}$ VILAÇA, Marcos. Op. cit. p. 45.

${ }^{262}$ Hely Lopes Meirelles classifica o controle da atividade administrativa de acordo com o "Poder, órgão ou autoridade que o exercita ou o fundamento, o modo e o momento de sua efetivação". Há, assim, o controle administrativo ou executivo, o controle legislativo ou parlamentar e o judiciário ou judicial que podem ser, de acordo com o seu fundamento, hierárquicos ou finalísticos; quanto à localização do órgão que os realiza, internos ou externos; quanto ao momento, prévios, concomitantes ou subsequientes e, quanto ao aspecto controlado, de legalidade ou de mérito. Para detalhes, consultar: MEIRELLES, Hely Lopes. Direito administrativo... Op. cit. pp. 660-718. Eduardo Lobo Botelho Gualazzi, por seu turno, prefere a tipologia seguinte: controles de legitimidade (incluindo a constitucionalidade e a legalidade), que se subdividem em controle jurisdicional e administrativo; controles de supervisão político-administrativa (abrangendo o mérito da atividade administrativa), que se apresentam como controles técnico, contábil, de gestão, de resultados, de eficiência, de planejamento e de coordenação; e controles mistos (legitimidade e supervisão político- 
de conceitos diferenciados para estabelecer as suas fórmulas, havendo, assim, uma pluralidade de modos para proceder à sua classificação.

Analisemos, então, as classificações que entendemos ser as mais importantes para o objeto de nossa tese.

\subsubsection{Quanto ao órgão controlador}

Antes de abordarmos a classificação propriamente dita, é preciso relembrar que, anteriormente, explicamos que a atividade de controle só existe graças à separação de Poderes. Natural, então, que os Poderes Executivo, Legislativo e Judiciário dêem nomes a tais controles exercidos sobre os outros Poderes. Acrescentamos, ainda, neste item, o controle popular e o efetivado pelos órgãos autônomos de controle, dos quais são exemplos o Tribunal de Contas e o Ministério Público. Os motivos para as inserções do povo, do Ministério Público e do Tribunal de Contas serão explanados nos tópicos a eles referentes.

\subsubsection{Controle administrativo (ou pelo Poder Executivo)}

Maria Sylvia Zanella Di Pietro ${ }^{264}$ ensina que este controle é o realizado pela Administração Pública no sentido lato (isto é, abrangendo os órgãos administrativos do Executivo, do Legislativo e do Judiciário) sobre suas próprias atividades, podendo ser de legalidade e de mérito, por iniciativa própria ou por provocação. Hely Lopes Meirelles ${ }^{265}$, na mesma linha, assevera tratar-se da fiscalização que o Poder Executivo e os órgãos administrativos dos demais Poderes efetuam sobre seus próprios atos, com o intuito de que sejam produzidos em conformidade com a lei. $\mathrm{O}$ controle serve exatamente para garantir que o serviço seja desempenhado de modo eficiente, proporcionando, aos administrados, o atendimento de seus direitos fundamentais individuais.

administrativa), que englobam os controles interno e externo, com preponderância programáticoorçamentária. Para detalhes, consultar: GUALAZZI, Eduardo Lobo Botelho. Op. cit. p. 31.

${ }^{263}$ Citamos, como exemplo, Jose Anibal Cagnoni, que classifica o controle em: quanto ao órgão que se deve controlar (parlamentar, administrativo, judicial e popular), destacando-se, neste tópico, ainda, o Tribunal de Contas, como órgão autônomo de controle; quanto ao objeto (genérico ou individual); quanto ao procedimento (de ofício, por provocação); em relação ao tempo ou momento: prévio, concomitante ou posterior e quanto aos efeitos (preventivo ou repressivo). CAGNONI, Jose Anibal. Op. cit. pp. 368-378.

${ }^{264}$ DI PIETRO, Maria Sylvia Zanella. Direito... Op. cit. pp. 692-693.

${ }^{265}$ MEIRELLES, Hely Lopes. Op. cit. pp. 664-665. 
Tratando-se da Administração direta, o controle administrativo chama-se autotutela, na medida em que autoriza "a Administração Pública a rever os próprios atos quando ilegais, inoportunos ou inconvenientes" ${ }^{, 266}$ podendo, inclusive, punir os seus funcionários em processos administrativos. Cuida-se, também, neste caso, de um controle interno, pois realizado pela própria Administração. A autotutela pode ocorrer $e x$ officio, quando a própria autoridade verifica a ilegalidade e a desfaz, podendo punir seus agentes, ou pode ser provocada, no caso da interposição de recurso pelo administrado.

O recurso administrativo constitui uma forma de o administrado exercer o seu direito fundamental de petição, previsto na alínea "a" ${ }^{267}$ do inciso XXXIV do artigo $5^{\circ}$ da Constituição Federal. Este direito é de extrema importância, porque permite ao administrado formular pedidos ou reclamações a qualquer dos Poderes, sem precisar socorrer-se do Poder Judiciário. Representações, reclamações administrativas, pedidos de reconsideração são exemplos de recursos administrativos à disposição do administrado para fazer valer seus direitos diante dos órgãos administrativos de qualquer dos Poderes.

\subsubsection{Controle judicial}

Discorrendo sobre o conceito de controle judicial, Seabra Fagundes explica: "quando o Poder Judiciário, pela natureza da sua função, é chamado a resolver as situações contenciosas entre a Administração Pública e o indivíduo, tem lugar o contrôle jurisdicional das atividades administrativas". ${ }^{268}$

Também aqui se deve entender, como faz Maria Sylvia Zanella Di Pietro, a "Administração Pública" no seu sentido lato, ou seja, o controle judicial abrange os atos administrativos praticados pelos Poderes Executivo, Legislativo e pelo próprio Judiciário, quando eivados de ilegalidades.

É um controle que depende de provocação e que se manifesta sobre a legalidade do ato administrativo, não se admitindo o pronunciamento acerca do mérito

\footnotetext{
${ }^{266}$ DI PIETRO, Maria Sylvia Zanella. Direito... Op. cit. p. 693.

${ }^{267}$ Dispõe o artigo 5, XXXIV, alínea "a", da Constituição Federal: "Art. 5. (...). XXXIV: "são a todos assegurados, independentemente do pagamento de taxas: a) o direito de petição aos Poderes Públicos em defesa de direitos ou contra ilegalidade ou abuso de poder”. BRASIL. Constituição (1988). Constituição da República Federativa do Brasil: promulgada em 5 de outubro de 1988: atualizada até a Emenda Constitucional no 67, de 22-12-2010. 45 a ed. ampl. São Paulo: Saraiva, 2011. p. 7.

${ }^{268}$ FAGUNDES, M. Seabra. O contrôle dos atos administrativos pelo Poder Judiciário. $4^{\mathrm{a}}$ ed. atual. Rio de Janeiro: Forense, 1967. p. 111.
} 
(conveniência e oportunidade da Administração). Realiza-se, ainda, sobre o aspecto da moralidade do ato (artigos $5^{\circ}$, LXXIII e 37 da Constituição Federal), nos dizeres de Maria Sylvia Zanella Di Pietro ${ }^{269}$.

O administrado pode socorrer-se do Judiciário contra ato proferido pela Administração Pública por intermédio de diversas ações, como a ação de indenização, por exemplo, ou através dos remédios constitucionais (habeas data, mandado de injunção, mandado de segurança, ação popular etc).

Também é possível que um ato administrativo seja objeto de uma ação direta de inconstitucionalidade (controle concentrado), proposta perante o Supremo Tribunal Federal, na hipótese de se tratar de um ato normativo federal ou estadual que contrarie a Constituição Federal (artigo 102, I, “a”), ou perante o Tribunal de Justiça, quando um ato normativo estadual ou municipal ferir a Constituição Estadual (artigo 125, $\S 2^{\circ}$, da Constituição Federal).

Cuida-se, ademais, de um controle em que o Poder Judiciário detém o monopólio da jurisdição, em razão do disposto no inciso XXXV do artigo $5^{\circ}$ da Constituição Federal, que estabelece que "a lei não excluirá da apreciação do Poder Judiciário lesão ou ameaça a direito" ${ }^{, 270}$. Tal preceito consagra o sistema da jurisdição una do Poder Judiciário, não se admitindo a existência de uma jurisdição contenciosa administrativa para cuidar de assuntos em que a Administração Pública seja parte.

Seabra Fagundes, no entanto, aponta duas $\operatorname{ressalvas}^{271}$ ao monopólio da jurisdição do Poder Judiciário decorrente do citado artigo $5^{\circ}, \mathrm{XXXV}$, da Constituição Federal. São elas: o controle efetuado pelo Congresso Nacional nos casos de crimes de responsabilidade praticados pelo Presidente e Vice-Presidente da República (o

\footnotetext{
${ }^{269}$ DI PIETRO, Maria Sylvia Zanella. Direito... Op. cit. p. 709.

${ }^{270}$ BRASIL. Constituição (1988). Constituição da República Federativa do Brasil: promulgada em 5 de outubro de 1988: atualizada até a Emenda Constitucional no 67, de 22-12-2010. 45 a ed. ampl. São Paulo: Saraiva, 2011. p. 7.

${ }^{271}$ É pelo fato de o monopólio da jurisdição comportar duas ressalvas - controle pelo Congresso Nacional nos crimes de responsabilidade do Presidente da República e julgamento das contas públicas dos administradores e demais responsáveis por dinheiros públicos - que, em nosso entendimento, Hely Lopes Meirelles refere-se ao controle jurisdicional como sendo privativo (e não exclusivo) do Poder Judiciário. Nas palavras do autor, "controle judiciário ou judicial é o exercido privativamente pelos órgãos do Poder Judiciário sobre os atos administrativos do Executivo, do Legislativo e do próprio Judiciário quando realiza atividade administrativa". (grifos nossos). MEIRELLES, Hely Lopes. Direito administrativo... Op. cit. p. 701.
} 
mesmo válido para os âmbitos estaduais e municipais) e o controle das contas públicas, procedido pelo Tribunal de Contas. Nas palavras do autor:

\begin{abstract}
"Duas exceções restritas admite a Constituição ao monopólio jurisdicional do Poder Judiciário, no que concerne à matéria contenciosa administrativa.

A primeira diz respeito aos crimes de responsabilidade do Presidente da República, dos ministros de Estado, quando conexos com os dêsse, e dos ministros do Supremo Tribunal Federal. O seu julgamento competirá ao Congresso.

A segunda se refere ao julgamento da regularidade das contas dos administradores e demais responsáveis pela guarda ou aplicação de bens ou fundos públicos atribuído ao Tribunal de Contas". ${ }^{272}$ (grifos nossos)
\end{abstract}

A lição de Seabra Fagundes foi proferida sob a égide da Constituição de 1967. Pode, porém, ser aproveitada em relação ao ordenamento pátrio vigente, pelo fato de as matérias referentes ao impeachment e ao julgamento das contas dos demais administradores terem sido recepcionadas pela Constituição Federal de 1988.

Assim é que, no que tange à primeira exceção, observamos que o julgamento do Presidente e do Vice-Presidente da República nos crimes de responsabilidade, bem como das demais autoridades ${ }^{273}$, previstas nos incisos I e II do artigo 52 da Constituição Federal de 1988, também fica a cargo do Congresso Nacional, da seguinte forma: o procedimento é instaurado se obtiver a concordância de, pelo menos, dois terços dos membros da Câmara dos Deputados (artigo 51, $\mathrm{I}^{274}$ ). Iniciada a sessão, que se desenvolve no Senado Federal, são necessários, pelo menos, dois terços dos votos dos senadores para a condenação do Presidente da República ou do Vice-Presidente à perda do cargo, com a inabilitação, por oito anos, para o exercício da função pública, sem prejuízo

\footnotetext{
${ }^{272}$ FAGUNDES, M. Seabra. Op. cit. p. 139.

${ }^{273}$ As autoridades que podem sofrer o processo de impeachment estão previstas nos incisos I e II do artigo 52 da Constituição Federal e são: o Presidente da República e seu Vice e os Ministros de Estado, os Comandantes da Marinha, Exército e Aeronáutica nos crimes de responsabilidade conexos com os do Presidente ou Vice (artigo 52, I), bem como os Ministros do Supremo Tribunal Federal, os membros do Conselho Nacional de Justiça e do Ministério Público, o Procurador-Geral da República e o Advogado da União (inciso II do artigo 52). BRASIL. Constituição (1988). Constituição da República Federativa do Brasil: promulgada em 5 de outubro de 1988: atualizada até a Emenda Constitucional no 67, de 22-12-2010. $45^{\mathrm{a}}$ ed. ampl. São Paulo: Saraiva, 2011. p. 58.

274 Dispõe o artigo 51, I, da Constituição Federal de 1988: "Compete privativamente à Câmara dos Deputados: I - autorizar, por dois terços de seus membros, a instauração de processo contra o Presidente e o Vice-Presidente da República e os Ministros de Estado". ${ }^{274}$ BRASIL. Constituição (1988). Constituição da República Federativa do Brasil: promulgada em 5 de outubro de 1988: atualizada até a Emenda Constitucional no 67, de 22-12-2010. 45 ed. ampl. São Paulo: Saraiva, 2011. p. 58.
} 
das demais sanções cabíveis ${ }^{275}$, nos termos do que dispõe o parágrafo único do artigo 52 da Constituição Federal. Todo o procedimento do crime de responsabilidade contará, ainda, com a obrigatória presença, no Congresso Nacional, do Presidente do Supremo Tribunal Federal, que atuará como Presidente da sessão, cumprindo-lhe assegurar a observância da lei e da Constituição Federal e proferir a sentença condenatória, se for o caso, após a votação da matéria pelo Senado Federal.

A segunda exceção, por seu turno, concerne ao julgamento das contas dos demais administradores pelo Tribunal de Contas e está igualmente prevista na Constituição Federal de 1988, só que no inciso II do artigo 71, que determina competir ao Tribunal de Contas da União “julgar as contas dos administradores e demais responsáveis por dinheiros, bens e valores públicos da administração direta e indireta, incluídas as fundações e sociedades instituídas e mantidas pelo Poder Público federal, e as contas daqueles que derem causa a perda, extravio ou outra irregularidade de que resulte prejuízo ao erário público". ${ }^{276} \mathrm{O}$ julgamento das contas é realizado pelo Tribunal de Contas e tratase de julgamento quanto aos aspectos contábil, financeiro, orçamentário, operacional e patrimonial. $^{277}$

O ponto comum entre o Congresso Nacional e o Tribunal de Contas é que a ambos foi conferida a tarefa de julgamento, consistindo este, como já explicado, exceção ao monopólio da jurisdição do Poder Judiciário. Sobre o julgamento de tais órgãos, profere Seabra Fagundes:

"Ao julgar, por crimes de responsabilidade, o Presidente da
República, Ministros de Estado, o Procurador Geral da República e
ministros do Supremo Tribunal Federal, exerce o Senado função
tipicamente judicante.
O mesmo é de dizer da Câmara dos Deputados, quando atua na fase
preliminar do processo de responsabilidade do chefe do Poder

${ }^{275}$ As demais sanções cabíveis, que podem ser examinadas pelo Poder Judiciário, são as civis e penais (estas últimas previstas no Código Penal e nas leis esparsas).

${ }^{276}$ BRASIL. Constituição (1988). Constituição da República Federativa do Brasil: promulgada em 5 de outubro de 1988: atualizada até a Emenda Constitucional nº 67, de 22-12-2010. 45 a ed. ampl. São Paulo: Saraiva, 2011. pp. 69-70.

277 É o que determina o artigo 70, caput, da Constituição Federal de 1988: “A fiscalização contábil, financeira, orçamentária, operacional e patrimonial da União e das entidades da administração direta e indireta, quanto à legalidade, legitimidade, economicidade, aplicação das subvenções e renúncia de receitas, será exercida pelo Congresso Nacional, mediante controle externo, e pelo sistema de controle interno de cada Poder”. BRASIL. Constituição (1988). Constituição da República Federativa do Brasil: promulgada em 5 de outubro de 1988: atualizada até a Emenda Constitucional $n^{\circ}$ 67, de 22-12-2010. 45a ed. ampl. São Paulo: Saraiva, 2011. p. 69. 
Executivo ou de Ministro de Estado (equivalente à de pronúncia no processo penal comum), para declarar procedente ou improcedente a acusação.

(...)

O Tribunal de Contas não aparece na Constituição como órgão componente do Poder Judiciário.

(...)

Não obstante isso, o art. 71, $\S 4^{\circ}$ [da Constituição de 1967], lhe comete o julgamento da regularidade das contas dos administradores e demais responsáveis por bens ou dinheiros públicos, o que implica em investi-lo no parcial exercício da funcão judicante. Não bem pelo emprêgo da palavra julgamento, mas sim pelo sentido definitivo da manifestação da côrte, pois se a regularidade das contas pudesse dar lugar a nova apreciação (pelo Poder Judiciário), o seu pronunciamento resultaria em mero e inútil formalismo. Sob êsse aspecto restrito (o criminal fica à Justiça da União) a Côrte de Contas decide conclusivamente. Os órgãos do Poder Judiciário carecem de jurisdição para examiná-lo". ${ }^{278}$ (grifos nossos)

Importante ressaltar as conclusões de Seabra Fagundes: o Senado Federal "julga" o Presidente da República nos crimes de responsabilidade e, quando o faz, pratica atividade judicante. O Tribunal de Contas, por sua vez, também "julga", não, contudo, com o mesmo vigor que é conferido ao Senado Federal. O julgamento da Corte de Contas, segundo o autor, consiste no "parcial exercício da função judicante".

Qual é, então, a diferença entre estes dois “julgamentos”, já que ambos representam exceções ao monopólio da jurisdição? Ou, ainda, qual a razão de ser conferida a tarefa judicante em sua plenitude ao Senado, na primeira exceção, e apenas parcialmente, na segunda, ao Tribunal de Contas? A resposta, pensamos, decorre de duas situações.

A primeira reside no fato de "quem" ou "o que" é julgado. É que o Senado Federal julga o Presidente da República - a pessoa do Presidente - nos crimes de responsabilidade, podendo apenar "a pessoa" com a perda do mandato e a inabilitação por oito anos. Entretanto, as demais sanções - penais e civis cabíveis -, nos termos do parágrafo único do artigo 52, poderão ser analisadas, agora sim, pelo Poder Judiciário e não pelo Legislativo.

A situação é diferente em relação ao Tribunal de Contas. É que este julga tão somente as contas dos administradores e não a sua pessoa. Dessa forma, o julgamento das contas e da pessoa é realizado em instâncias diferentes, independentes uma

${ }^{278}$ FAGUNDES, M. Seabra. Op. cit. pp. 140-142. 
da outra, da seguinte forma: as contas, no Tribunal de Contas e a pessoa, no Poder Judiciário. O que pode acontecer é as contas do administrador público serem rejeitadas sem que nenhuma sanção civil ou penal seja aplicada à pessoa do administrador pelo Poder Judiciário ou, ao contrário, as contas serem aprovadas pela Corte de Contas e, ainda assim, o indivíduo vir a ser apenado civil ou penalmente em âmbito jurisdicional.

\begin{abstract}
A segunda diferença decorre da "definitividade",279 e da "irrecorribilidade" da decisão que alcança o processo do impeachment no Congresso Nacional, o que não acontece, totalmente, no âmbito do Tribunal de Contas. Como consequência, no primeiro caso não se admite a incidência do inciso XXXV do artigo $5^{\circ}$ da Constituição Federal sendo, no entanto, possível a sua aplicação na segunda situação, caso tenham sido praticadas ilegalidades ou inconstitucionalidades pelo órgão de controle durante o procedimento.
\end{abstract}

\footnotetext{
${ }^{279}$ Maria Sylvia Zanella Di Pietro e Hely Lopes Meirelles defendem posicionamento contrário à Corte de Contas exercer o "parcial exercício da função judicante" tal como assevera M. Seabra Fagundes. A autora explica a diferença entre coisa julgada e coisa julgada administrativa: "Na função jurisdicional, o Poder Judiciário atua como terceiro estranho à lide; a relação é trilateral, porque compreende autor, réu e juiz, não sendo este parte na relação que vai decidir. Por isso mesmo, a função é imparcial e, como tal, torna-se definitiva, pondo fim ao conflito; por outras palavras, ela produz coisa julgada. Na função administrativa, a Administração Pública é parte na relação que aprecia; por isso mesmo se diz que a função é parcial e, partindo do princípio de que ninguém é juiz e parte ao mesmo tempo, a decisão não se torna definitiva, podendo sempre ser apreciada pelo Poder Judiciário, $\underline{\boldsymbol{s}} \boldsymbol{e}$ causar lesão ou ameaça de lesão. Portanto, a expressão coisa julgada, no Direito Administrativo, não tem o mesmo sentido que no Direito Judiciário. Ela significa apenas que a decisão se tornou irretratável pela própria Administração". (grifos nossos). DI PIETRO, Maria Sylvia Zanella. Direito... Op. cit. p. 701. No mesmo sentido, Hely Lopes Meirelles: "a denominada coisa julgada administrativa, que, na verdade, é apenas uma preclusão de efeitos internos, não tem o alcance da coisa julgada judicial, porque o ato jurisdicional da Administração não deixa de ser um simples ato administrativo decisório, sem a força conclusiva do ato jurisdicional do Poder Judiciário. Falta ao ato jurisdicional administrativo aquilo que os publicistas norte-americanos chamam de the final enforcing power' e que se traduz livremente como o poder conclusivo da Justiça Comum". MEIRELLES, Hely Lopes. Direito administrativo... Op. cit. pp. 675-676. Maria Sylvia Zanela Di Pietro, em outra obra, rechaça o posicionamento de Seabra Fagundes citado no corpo de nosso trabalho, no sentido de que o Tribunal de Contas realizaria parcial exercício da jurisdição. A autora cita Oswaldo Aranha Bandeira de Mello e explica, quanto à questão da coisa julgada, que razão assiste ao autor, pois "não se trata de rejulgamento pela Justiça Comum, porque o Tribunal de Contas é órgão administrativo e não judicante, e sua denominação de Tribunal e a expressão julgar são equívocas. Na verdade, é um Conselho de Contas e não as julga, sentenciando a respeito delas, mas apura da veracidade delas para dar quitação ao interessado, em tendo-as como prestadas, ou promover a condenação criminal e civil dele, em verificando o alcance. Apura fatos. Ora, apurar fatos não é julgar”. MELLO, Oswaldo Aranha Bandeira de. Princípios gerais de direito administrativo. v. 2. Rio de Janeiro: Forense, 1974. p. 172. Apud DI PIETRO, Maria Sylvia. Coisa julgada: aplicabilidade a decisões do Tribunal de Contas da União. Revista do Tribunal de Contas da União.v. 27. $\mathrm{n}^{\circ}$ 70. Brasília: out./dez., 1996. pp. 27-28. E conclui a autora: "Realmente, mesmo com relação à matéria de fato apreciada pelo Tribunal de Contas, ainda que envolvendo questões puramente contábeis, não se pode subtrair o assunto à apreciação do Poder Judiciário, em face do artigo $5^{\circ}, \mathrm{XXXV}$, da Constituição". DI PIETRO, Maria Sylvia. Coisa julgada: aplicabilidade a decisões do Tribunal de Contas da União. Revista do Tribunal de Contas da União.v. 27. $\mathrm{n}^{\circ}$ 70. Brasília: out./dez., 1996. p. 28.
} 
No que tange ao processo de impeachment, seja no caso da autorização dada pela Câmara dos Deputados, seja no julgamento feito pelo Senado Federal, a decisão de instaurar e de condenar ou não o Presidente da República e o seu Vice é política ${ }^{280}$, ficando, portanto, inserta no campo da discricionariedade que o ente possui. Desse modo, todo o procedimento relativo ao processo contra o Presidente da República, no crime de responsabilidade, ocorre no âmbito interno do Congresso Nacional, sem qualquer interferência do Poder Judiciário, a não ser no tocante à proteção da legalidade e da constitucionalidade desse procedimento. Ou seja, não incide, neste caso, o inciso XXXV do artigo $5^{\circ}$ da Constituição Federal, de modo que ao Poder Judiciário não é cabível manifestar-se sobre a instauração do processo ou a condenação do Presidente da República. Ressalte-se, novamente, o Poder Judiciário não pode intervir na decisão de instaurar o impeachment a não ser que haja ofensa aos princípios constitucionais e legais.

Sobre o tema, profere Marcelo Figueiredo: "muito embora tenha o impeachment caráter de processo político, não está afastada a intervenção judicial quando haja lesão a direitos individuais ou, ainda, falhas processuais". ${ }^{281}$

Manoel Gonçalves Ferreira Filho, cuidando do impeachment, explica que o seu objetivo “(...) é principalmente político: a destituição da autoridade culpada (v. art. 52, parágrafo único). Todavia, acompanha essa destituição uma sanção punitiva, uma 'pena' portanto, a 'inabilitação por oito anos, para o exercício de qualquer função pública' (art. 52, parágrafo único, in fine)". ${ }^{282}$ A destituição e a inabilitação são decisões tomadas, exclusivamente, pelo Congresso Nacional.

\footnotetext{
${ }^{280}$ Norberto Bobbio traz definição para a palavra política. Assevera o autor: "o verbete parte da origem da palavra 'política', derivada de politikós, o adjetivo de pólis, para então chegar a uma primeira definição formal da noção de política, mediante a qual tal noção passa a ser associada àquela de Estado (no sentido mais amplo). Passa então a ser definida como 'política' a esfera das 'atividades' que têm como 'termo de referência' o Estado. Mas as atividades políticas são logo em seguida diferenciadas em dois tipos, dependendo se o curso da ação se processe a partir do Estado, ou seja, a pólis dela seja o sujeito, como nos atos eminentemente políticos de comandar e de legislar, ou se o curso da ação se processe em direção ao Estado, ou melhor, em direção ao 'poder estatal', que é objeto dos atos igualmente políticos como o de conquistar ou derrubar tal poder”. BOBBIO, Norberto. Teoria geral da política: a filosofia política e as lições dos clássicos. BOVERO, Michelangelo (Org.). Tradução de Daniela Beccaccia Versiani. $6^{\mathbf{a}}$ Tiragem. Rio de Janeiro: Campus, 2000. pp. 32-33.

${ }^{281}$ FIGUEIREDO, Marcelo. $O$ controle... Op. cit. p. 65.

${ }^{282}$ FERREIRA FILHO, Manoel Gonçalves. Curso... Op. cit. pp. 165-166. O objetivo deste trabalho não é estudar a natureza jurídica do impeachment. É certo que a doutrina diverge a este respeito, ora entendendo que ela é meramente política, ora que se trata de natureza jurisdicional. Para nós, é suficiente considerar que a instauração do processo e a condenação do Presidente da República e do Vice-Presidente dependem de uma decisão política, bastando, para tal, a obtenção dos dois terços de votos dos membros do Congresso Nacional.
} 
O tratamento é diferente no que concerne ao Tribunal de Contas. A decisão acerca da regularidade ou irregularidade das contas é proferida pela Corte de Contas. O seu mérito não pode, em regra ${ }^{283}$, ser rediscutido pelo Poder Judiciário, sob pena de haver, nas palavras de Pontes de Miranda, com quem concordamos, "absurdo bis in idem". ${ }^{284}$ Em que pese não se admita ao Poder Judiciário reapreciar o mérito da decisão da Corte de Contas que julgou irregulares as contas de determinado administrador público, é possível, em face do que dispõe o inciso XXXV do artigo $5^{\circ}$ da Constituição Federal, perquirir o pronunciamento do Poder Judiciário acerca de uma ilegalidade ou inconstitucionalidade que se entenda praticada nesse julgamento realizado pelo Tribunal de Contas.

Ressalte-se, o Judiciário não pode julgar regulares as contas que o Tribunal de Contas entendeu irregulares, em razão do bis in idem, salvo se houver ilegalidade ou inconstitucionalidade. Não está autorizado, pois, a invadir o mérito do decidido pela Corte de Contas. Pode, no entanto, quando provocado, anular tal julgamento em face do desrespeito à lei ou à Constituição. É o caso, por exemplo, de o Tribunal de Contas não assegurar ao particular contratante o princípio constitucional do contraditório e da ampla defesa (artigo $5^{\circ}, \mathrm{LV}$ ), quando uma licitação e contrato dela decorrente estão sendo analisados. Sobre o tema, vejamos o entendimento do Supremo Tribunal Federal:

"I - Tribunal de Contas: competência: contratos administrativos (CF, art. 71 , IX e $\S \S 1^{\circ}$ e $\left.2^{\circ}\right)$. O Tribunal de Contas da União - embora não tenha poder para anular ou sustar contratos administrativos - tem competência, conforme o art. 71, IX, para determinar à autoridade administrativa que promova a anulação do contrato e, se for o caso, da licitação que se originou.

II - Tribunal de Contas: processo de representação fundado em invalidade de contrato administrativo: incidência das garantias do devido processo legal e do contraditório e ampla defesa, que impõem

\footnotetext{
${ }^{283}$ A regra é que a decisão do Tribunal de Contas não seja rediscutida no Poder Judiciário, a não ser que haja lesão ou ameaça de lesão. É que, como já foi explicado, incide o inciso XXXV do artigo $5^{\circ}$ da Constituição Federal, que determina que nenhuma lesão ou ameaça de lesão deixará de ser apreciada pelo Poder Judiciário. Além disso, como antes explanado, a coisa julgada administrativa significa que a decisão ficou irretratável somente para a Administração Pública, podendo ser rediscutida no Poder Judiciário mas, aqui, com a ressalva de que a nova discussão só é permitida se houver lesão ou ameaça de lesão.

${ }^{284}$ Acerca do bis in idem, no caso de o Tribunal de Contas julgar e a matéria ser julgada novamente pelo Poder Judiciário, Pontes de Miranda, comentando a Constituição de 1946, cuja explicação pode ser aproveitada para a Constituição atual, profere: "hoje, e desde 1934, a função de julgar as contas está, claríssima, no texto constitucional. Não havemos de interpretar que o Tribunal de Contas julgue, e outro juiz as re-julgue depois. Tratar-se-ia de absurdo bis in idem. Ou o Tribunal de Contas julga, ou não julga". (grifos nossos). MIRANDA, Pontes de. Comentários à Constituição de 1946. $2^{\mathrm{a}} \mathrm{ed}$. rev. e aum. v. II (arts. 15-97). São Paulo: Max Limonad, 1953. p. 340.
} 
assegurar aos interessados, a começar do particular contratante, a ciência de sua instauração e as intervenções cabíveis.

(...)

Os mais elementares corolários da garantia constitucional do contraditório e da ampla defesa são a ciência dada ao interessado da instauração do processo e a oportunidade de se manifestar e produzir ou requerer a produção de provas; de outro lado, se se impõe a garantia do devido processo legal aos procedimentos administrativos comuns, a fortiori, é irrecusável que a ela há de submeter-se o desempenho de todas as funções de controle do Tribunal de Contas, de colorido quase - jurisdicional.

A incidência imediata das garantias constitucionais referidas dispensariam a previsão legal expressa de audiência dos interessados; de qualquer modo, nada exclui os procedimentos do Tribunal de Contas da aplicação subsidiária da lei geral de processo administrativo federal (L. 9.784/99), que assegura aos administrados, entre outros, o direito a 'ter ciência da tramitação dos processos administrativos em que tenha a condição de interessado, ter vista dos autos (art. $3^{\circ}$, II), formular alegações e apresentar documentos antes da decisão, os quais serão objeto de consideração pelo órgão competente.

A oportunidade de defesa assegurada ao interessado há de ser prévia à decisão, não lhe suprindo a falta a admissibilidade de recurso, mormente quando o único admissível é o de reexame pelo mesmo plenário do TCU, que emanou a decisão.

(...) por maioria de votos, em deferir parcialmente a segurança, para anular o processo a partir da remessa ao Tribunal de Contas da União, inclusive, a fim de que seja intimada a interessada, ora impetrante". ${ }^{285}$ (grifos nossos)

Observa-se, da ementa, que o Supremo Tribunal Federal não alterou a decisão do Tribunal de Contas, que havia determinado à autoridade competente que suspendesse o contrato julgado irregular. Ateve-se à análise da ocorrência ou não do cerceamento de defesa que, por derivar de um princípio constitucional, maculou a decisão do Tribunal de Contas da União. Repita-se: a decisão do Tribunal de Contas da União foi anulada por afronta ao princípio constitucional do contraditório e da ampla defesa ${ }^{286}$, não

${ }^{285}$ Mandado de Segurança no 23.550-1/DF, Rel. Min. Marco Aurélio. Rel. para o acórdão: Min. Sepúlveda
Pertence. Tribunal Pleno. Julgado em $04 / 04 / 01$. Disponível
http://redir.stf.jus.br/paginadorpub/paginador.jsp?docTP=AC\&docID=85979>, acesso em 28 de ago. 2011 .
${ }_{286}$ No mesmo sentido entendeu o Tribunal de Justiça do Estado de São Paulo quando do julgamento da
Apelação Cível n ${ }^{\circ} 278.905-5 / 2-00-S P$ que requeria a reforma de sentença que decidiu que a ausência de
notificação pessoal do Presidente de Fundação municipal, para se defender da rejeição das contas de
mencionada Fundação, violava o "due process of law" e configurava o desrespeito ao princípio
constitucional da ampla defesa. Eis a ementa: "Juízo de Ofício e Apelação Cível. Mandado de Segurança.
Tribunal de Contas - Contas de fundação julgadas irregulares - Falta de notificação pessoal do presidente da
fundação - Violação do "due process of law", não sendo válida mera intimação pela imprensa - Desrespeito
ao direito de ampla defesa - Segurança concedida - Sentença mantida. Recurso de ofício, que fica conhecido,
e recurso voluntário, improvidos". No corpo do voto, assim se manifestou a Desembargadora Relatora "Na
hipótese em exame, o processo que teve trâmite perante o Tribunal de Contas não se consubstanciava em
processo de "tomada de contas", mas em processo de exame e julgamento de contas anuais da fundação,
sustentando o apelante ser aplicável à espécie a regra do artigo 90, que não exige a notificação pessoal do 
proferindo, o Judiciário, novo exame sobre o mérito da matéria discutida em seara interna da Corte de Contas.

Pelos motivos expostos, verifica-se que estes dois "julgamentos" pelo Senado Federal nos crimes de responsabilidade e pelo Tribunal de Contas quanto à regularidade das contas dos administradores e demais responsáveis por dinheiro público cuidam de controles judicantes efetuados por órgãos que não pertencem ao Poder Judiciário, tratando-se, então, de exceções ao monopólio da jurisdição do Poder Judiciário, sem que tenham, porém, o condão de afetar a tarefa de controle desempenhada pelo Poder Judiciário.

De outra parte, importante destacar que os atos políticos praticados pelo Poder Público poderão, em situações excepcionais, ser objeto de controle judicial. Atos políticos ${ }^{287}$ são decisões provenientes dos órgãos de Governo (Executivo, Legislativo ou Judiciário), emanados de competência constitucional e fundamentados na conveniência e oportunidade ${ }^{288}$ do agente que os produziu. Como regra, não estão sujeitos a controle judicial. Poderão sê-lo, no entanto, quando ferirem direito individual ou coletivo da pessoa. Isto em razão do disposto na Constituição Federal, que prescreve que "a lei não excluirá da

interessado. Todavia, razão não lhe assiste, eis que o artigo 90 da Lei Complementar $n^{\circ} 709 / 93$ fere os princípios do contraditório e da ampla defesa, desrespeitando o "due process of law". Isto porque o processo que teve trâmite tem nítida natureza de processo administrativo impositivo de sanção, devendo ser preservado aos interessados sua ciência e possibilidade do exercício de defesa, o que, por si só, erige a notificação pessoal em providência inafastável para a garantia de sua regularidade, pois é por meio de tal ato que se dá conhecimento ao interessado da existência do processo e se permite o exercício do contraditório. Assim, deve ser integralmente mantida a R. Sentença. À vista do exposto, pelo meu voto, nego provimento aos recursos oficial e voluntário". "Negaram provimento aos recursos, v. u." (Apelação Cível com Revisão n 278.905-5/2-00, da Comarca de São Paulo-Fazenda Pública. Rel. Desembargadora Christine Santini. Segunda Câmara de Direito Público do Tribunal de Justiça do Estado de São Paulo, julgado em 18/12/07). Disponível em: <http://esaj.tjsp.jus.br/cjsg/getArquivo.do?cdAcordao=2435542>, acesso em 01 de out. 2011. ${ }^{287}$ Para Hely Lopes Meirelles, os atos políticos "são os que, praticados por agentes do Governo, no uso de competência constitucional, se fundam na ampla liberdade de apreciação da conveniência ou oportunidade de sua realização, sem se aterem a critérios jurídicos preestabelecidos. São atos governamentais por excelência, e não apenas de administração. São atos de condução dos negócios públicos, e não simplesmente de execução de serviços públicos. Daí seu maior discricionarismo e, conseqüentemente, as maiores restrições para o controle judicial. Mas nem por isso afastam a apreciação da Justiça quando argüidos de lesivos a direito individual ou ao patrimônio público". MEIRELLES, Hely Lopes. Direito administrativo... Op. cit. p. 705. Maria Sylvia Zanela Di Pietro explica, ainda, existirem os atos exclusivamente políticos e quase políticos (ou não exclusivamente políticos). Os primeiros não afetam direitos individuais e não são passíveis de controle judicial. Os segundos podem violar os direitos individuais, "embora dizendo respeito a interesses superiores do Estado, da nação, da sociedade" sendo cabível, neste caso, então, o controle pelo Poder Judiciário. DI PIETRO, Maria Sylvia Zanella. Direito... Op. cit. p. 710.

${ }^{288}$ São exemplos de atos políticos trazidos por Hely Lopes Meirelles, o veto a um projeto de lei aposto pelo Poder Executivo, a cassação de um mandato por parte do Poder Legislativo e a escolha de advogado para compor o quinto constitucional. Explica o autor que, "em todos esses exemplos são as conveniências do Estado que comandam o ato e infundem-lhe caráter político que o torna insuscetível de controle judicial quanto à valoração de seus motivos”. MEIRELLES, Hely Lopes. Direito administrativo... Op. cit. p. 705. 
apreciação do Poder Judiciário lesão ou ameaça a direito" (artigo 5, XXXV). Assim, não basta aduzir que o ato é político para que não haja incidência do controle judicial. Consoante ensina Hely Lopes Meirelles, “o que se nega ao Poder Judiciário é, depois de ter verificado a natureza e os fundamentos políticos do ato, adentrar seu conteúdo e valorar seus motivos". 289 O julgamento das contas do Prefeito, proferido pela Câmara dos Vereadores aprovando-as ou rejeitando-as é um exemplo de ato político. A decisão da Câmara Municipal poderá, contudo, ser rediscutida no Poder Judiciário se houver lesão a direito individual ou coletivo da pessoa ${ }^{290}$ atingida.

\subsubsection{O controle político}

Esta função será tratada no Capítulo IV, item 4.3.1.2 (A função de controle político) quando nos dedicarmos à explanação sobre o controle político.

\subsubsection{O controle realizado pelos órgãos constitucionais autônomos}

A Constituição de 1988 prevê a existência de outros órgãos, além dos Poderes Executivo, Legislativo e Judiciário, que, de maneira autônoma, também exercem a função de controle. São os chamados órgãos constitucionais autônomos. A função precípua destes, aliás, é exatamente a de fiscalizar os demais órgãos.

Em seguida, analisaremos os controles efetuados pelo Ministério Público e pelo Tibunal de Contas.

\subsection{O controle pelo Ministério Público}

Um destes órgãos é o Ministério Público, que tem como cerne a defesa da ordem jurídica, do regime democrático e dos interesses sociais e individuais indisponíveis, tal como determina o "caput” do artigo 127 da Constituição Federal.

Interessante que, quanto ao Ministério Público, é a própria Constituição Federal que reconhece a sua independência e autonomia. Primeiro, porque a

\footnotetext{
${ }^{289}$ Idem. pp. 705-706.

${ }^{290}$ Os ex-Prefeitos Luíza Erundina de Souza e Celso Roberto Pitta do Nascimento recorreram ao Judiciário contra a rejeição de suas contas na Câmara dos Vereadores. Para detalhes, conferir item 5.3.1 (A rejeição das contas de governo da Prefeita Luíza Erundina de Souza) e item 5.3.2 (A rejeição das contas de governo do Prefeito Celso Roberto Pitta do Nascimento), respectivamente.
} 
ele dedicou uma seção - a Seção I - "Do Ministério Público", do Capítulo VI - "Das Funções Essenciais à Justiça" -, do Título IV - "Da Organização dos Poderes" -, separada das relativas aos Poderes da República e, em segundo lugar, porque expressamente lhe conferiu a independência funcional como um de seus princípios institucionais (artigo 127, $\S 1^{\circ}$, da Constituição Federal), a autonomia funcional e administrativa para exercer suas funções e organizar a sua carreira (artigo $127, \S 2^{\circ}$ ) e o direito de apresentar a sua própria proposta orçamentária ao Poder Executivo (artigo 127, § $3^{0291}$ ). Vale dizer que o Ministério Público tem funções e orçamento próprios, exercendo as primeiras de forma totalmente desvinculada de qualquer dos Poderes. De outro lado, detém autonomia para determinar o modo como a receita será utilizada. Tudo isso leva Hugo Nigro Mazzilli a afirmar que o Ministério Público possui uma “(...) posição à parte dentro da tradicional tricotomia dos ramos do Poder, desvinculando-o, assim, de uma ligação excessiva, especialmente com o Poder Executivo e com as autoridades administrativas do governo". ${ }^{292}$

É, pois, órgão constitucional autônomo, que não pertence a nenhum dos Poderes e que objetiva a fiscalização dos direitos indisponíveis.

\subsection{O controle pelo Tribunal de Contas}

Outro órgão que detém autonomia no cenário pátrio, no tocante à função específica de controle, é o Tribunal de Contas. Sua função primordial é a de controlar os gastos públicos, protegendo o erário, convivendo este controle, que se chama externo, com os controles internos realizados pelos próprios órgãos dentro de suas unidades.

Em relação ao Tribunal de Contas, diferentemente do Ministério Público, foi ele inserido na Seção IX - "Da Fiscalização Contábil, Financeira e

\footnotetext{
${ }^{291}$ Dispõem os $\S \S 1^{\circ}$ ao $3^{\circ}$ do artigo 127 da Constituição Federal:

“Art. 127. (...). $\S 1^{\circ}$. São princípios institucionais do Ministério Público a unidade, a indivisibilidade e a independência funcional. $\S 2^{\circ}$. Ao Ministério Público é assegurada a autonomia funcional e administrativa, podendo, observado o disposto no art. 169, propor ao Poder Legislativo a criação e extinção de seus cargos e serviços auxiliares, provendo-os por concurso público de provas ou de provas e títulos, a política remuneratória e os planos de carreira; a lei disporá sobre sua organização e funcionamento. $\S 3^{\circ}$. O Ministério Público elaborará sua proposta orçamentária dentro dos limites estabelecidos na lei de diretrizes orçamentárias". BRASIL. Constituição (1988). Constituição da República Federativa do Brasil: promulgada em 5 de outubro de 1988: atualizada até a Emenda Constitucional no 67, de 22-12-2010. 45 a ed. ampl. São Paulo: Saraiva, 2011. p. 103.

${ }^{292}$ MAZZILLI, Hugo Nigro. O Ministério Público no Tribunal de Contas. Revista dos Tribunais. Ano 78. v. 650. São Paulo: Revista dos Tribunais, 1989. p. 43.
} 
Orçamentária" -, dentro do Capítulo I - "Do Poder Legislativo" -, também do Título IV “Da Organização dos Poderes”. Em que pese não haja, como para o Ministério Público, expressa disposição constitucional, entendemos que esse órgão é também constitucionalmente autônomo tal como já explicado no item 3.2 (A independência e a autonomia do Tribunal de Contas brasileiro) merecendo, por isso, o Tribunal de Contas um tópico somente seu.

Reforça nosso entendimento de que o Tribunal de Contas é um órgão autônomo, ou, como dito no item 3.2 referido, um órgão constitucionalmente autônomo, a lição do Ministro Carlos Ayres Britto, quando compara a relação que ocorre entre o Poder Judiciário e o Ministério Público com a existente entre o Poder Legislativo e o Tribunal de Contas:

\footnotetext{
"As proposições se encaixam. Não sendo órgão do Poder Legislativo, nenhum Tribunal de Contas opera no campo da subalterna auxiliaridade. Tanto assim que parte das competências que a Magna Lei confere ao Tribunal de Contas da União nem passa pelo crivo do Congresso Nacional ou de qualquer das Casas Legislativas Federais (bastando citar os incisos III, VI e IX do art. 71). O TCU se posta é como órgão da pessoa jurídica da União, diretamente, sem pertencer a nenhum dos três Poderes Federais. Exatamente como sucede com o Ministério Público, na legenda do art. 128 da Constituição, incisos I e II". ${ }^{293}$ (grifos nossos)
}

Com efeito. A lição do Ministro Carlos Ayres Britto é importante. O Tribunal de Contas tem, realmente, funções que pertencem somente a ele, insertas nos incisos I a XI do artigo 71 da Constituição Federal, sem que necessite, para desempenhálas, de autorização do Poder Legislativo, à exceção da sustação de contratos, que somente pode ser determinada pelo Poder Legislativo. Exsurge, assim, a autonomia da Corte de Contas. Daí porque merece ela, também, um tópico somente seu e relacionado com o controle das contas públicas que realiza.

As competências e a ação do Tribunal de Contas serão estudadas no Capítulo IV.

\footnotetext{
${ }^{293}$ BRITTO, Carlos Ayres. Op. cit. p. 62. O Ministro explica a relação entre o Poder Judiciário e o Ministério Público como sendo uma relação de soma, no sentido de que "não se pode exercer a jurisdição senão com a participação do Ministério Público". Assevera que a função jurisdicional se materializa com as atuações conjuntas do Poder Judiciário e do Ministério Público, sem que um se sobressaia em relação ao outro. Idem. Ibidem.
} 


\subsubsection{O controle popular (ou o controle social)}

Característica de um regime democrático constitucional é o controle popular do poder político. É que, em última análise, é ao povo que os que exercem o poder - seja o governante ou o parlamentar - devem prestar contas de seus atos, até para que sejam submetidos a julgamento popular nas urnas, sendo ou não reeleitos.

Ou seja, o "detentor supremo" 294 desse controle, como aduz Karl Loewenstein, em uma democracia constitucional, em que "todo o poder emana do povo e para ele é exercido", como ocorre no Brasil, acaba sendo o próprio eleitorado, que controla o Parlamento, o Governo e os Tribunais Judiciários ${ }^{295}$. Nas palavras do autor:

"A democracia constitucional é, pois, um sistema político em que a totalidade do povo - organizado como eleitorado e mobilizado para a ação política pelos partidos - participa livremente dos processos do poder. $\mathrm{O}$ eleitorado adquire, assim, a categoria de detentor supremo do poder exercendo um controle final sobre o Governo e o Parlamento". ${ }^{296}$ (grifos e tradução nossos)

Este controle acontece de duas formas: 1) indireta, quando o eleitorado escolhe, nas urnas, os seus governantes e parlamentares; ou 2) direta, por meio de plebiscitos, referendos, iniciativa popular de leis, mecanismos estes presentes no Brasil, ou, ainda, através de audiências públicas ou recall. Plebiscito, segundo Cláudio Lembo, “é a forma remota de participação popular cuja concepção se deve à antiga Roma". ${ }^{297}$ E adiante, continua: "no interior de uma cosmovisão democrática, a doutrina indica o plebiscito como meio para a aprovação ou oferecimento de contrariedade a ato de governo específico de natureza política". ${ }^{298}$ Em relação ao referendo, após esclarecer que o instituto é adotado em diversos ordenamentos constitucionais, como Estados Unidos, Espanha,

\footnotetext{
${ }^{294}$ LOEWENSTEIN, Karl. Op. cit. p. 326.

${ }^{295}$ Lembre-se que, no Capítulo I, explicamos que são quatro os detentores do poder político: o Parlamento, o Governo, os Tribunais Judiciários e o eleitorado.

296 'La democracia constitucional es um sistema político bajo el que la totalidad del 'pueblo' - organizado como electorado y movilizado para la acción política por los partidos - participa libremente en el proceso del poder. El electorado adquiere con esto la categoria del detentador supremo del poder ejerciendo un control final sobre el gobierno y el parlamento". LOEWENSTEIN, Karl. Op. cit. p. 326.

${ }^{297}$ LEMBO, Cláudio. Participação política e assistência simples no direito eleitoral. Rio de Janeiro: Forense Universitária, 1991. p. 37.

${ }^{298}$ Idem. p. 38.
} 
França, Portugal e Brasil ${ }^{299}$, o Professor assevera que o constituinte pátrio "deixando de se utilizar de exercícios de Direito Comparado, tornou-se agente de dispensável

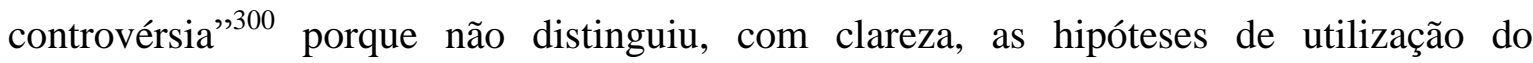
plebiscito e do referendo. ${ }^{301}$ Quanto à iniciativa popular de leis, "consiste na possibilidade de determinado número de cidadãos apresentar às Casas Legislativas projetos de lei, rompendo, assim a reserva antes deferida ao Executivo e aos integrantes do Legislativo". 302

Qualquer que seja o instrumento escolhido, é certo que o povo - ou o eleitorado, na visão de Karl Loewenstein - tem importância imediata no processo político e funciona como o ente que controla o exercício do poder.

No caso específico das contas públicas, este controle se faz mais forte porque a prestação de contas daquele que exerce o poder é obrigatória e é feita ao povo (ou ao eleitorado), que demonstra nas urnas a concordância ou não com o modo como o dinheiro público foi utilizado pelo governante ou pelo parlamentar, reelegendo-o ou não.

Em cenário doméstico, Helio Saul Mileski fala em controle social, ao invés de controle popular. Aduz o autor que o controle social "fica entendido como limitação do agir individual na sociedade" ${ }^{303}$, variando os mecanismos existentes para tal controle de acordo com a época histórica ou com as necessidades humanas. Ainda

\footnotetext{
299 Alexandre Sanson explica a diferença entre plebiscito e referendo no Brasil: "A Constituição Federal vigente apresenta no seu artigo 14, três mecanismos de intervenção direta nos negócios públicos: plebiscito (inciso I), o referendo (inciso II) e a iniciativa popular (inciso III). O plebiscito e o referendo constituem autênticos instrumentos de manifestação popular. Através do primeiro, o povo é instado a opinar acerca de uma medida particular de governo, direcionando os rumos do Estado; no segundo, a alteração legislativa ou a decisão administrativa já ocorreu, cabendo aos membros da sociedade aprová-la ou rejeitá-la. A existência de dois vocábulos diferentes e de experiências diversas permite, por vezes, uma certa confusão entre suas acepções, razão pela qual há países que colocam tal dicotomia em segundo plano, utilizando o termo consulta popular, mais abrangente, ou denominando plebiscito ou referendo todas as vezes que o povo é chamado a dar o seu parecer sobre os assuntos estatais'. SANSON, Alexandre. Dos institutos de democracia semidireta (plebiscito, referendo e iniciativa popular) como fontes de fortalecimento da cidadania ativa. Dissertação de Mestrado apresentada na Universidade Presbiteriana Mackenzie. São Paulo, 2007. pp. 87-88.

${ }^{300}$ LEMBO, Cláudio. Participação... Op. cit. p. 43.

${ }^{301}$ Cláudio Lembo sugere que o legislador pátrio poderia fazer como o ordenamento italiano. Nas palavras do Professor: "Agiu tautologicamente o constituinte brasileiro. Melhor seria se tivesse se espelhado na elaboração italiana que, na Constituição de 1947, conferiu ao referendum a tarefa de submeter à vontade popular as hipóteses de manutenção, revogação ou alteração de leis em vigor, conforme dispositivo inserido em seu art. 138". Idem. p. 42.

${ }^{302}$ Idem. p. 44.

${ }^{303}$ MILESKI, Helio Saul. O controle da gestão pública. São Paulo: Revista dos Tribunais, 2003. p. 152.
} 
consoante o autor, o momento presente exige da Administração Pública que os seus atos se façam sob o manto do princípio da transparência. Sobre o tema, assevera:

\begin{abstract}
"A mais moderna exigência de controle sobre os atos da Administração Pública é a transparência, especialmente a transparência fiscal, por ser esta um fator relevante para o estabelecimento de uma boa governança, na medida em que possibilita um conhecimento público dos elementos idealizadores da política fiscal e de seus resultados, proporcionando uma participação popular que amplia o controle sobre os governos no que diz respeito à elaboração e à execução dessa política fiscal". ${ }^{304}$ (grifos nossos)
\end{abstract}

Com efeito, a transparência ${ }^{305}$ dos atos do governo é tão importante que ganhou previsão, no campo das finanças públicas, na Lei de Responsabilidade Fiscal (Lei Complementar $n^{\circ} 101 / 2000$ - artigo 48 ${ }^{306}$ ). De acordo com o seu artigo 48, o orçamento, a prestação de contas e a respectiva elaboração do parecer prévio são instrumentos essenciais a um "bom governo". Para tanto, imprescindível a transparência dos atos governamentais, especialmente no tocante ao uso dos recursos públicos.

No mesmo sentido, aduz Cláudio Lembo:

"No campo do Direito, uma legislação avançada, que limitando a ação dos governantes, implantou uma nova visão do ato de administrar, exigindo que os ativos públicos sejam aplicados de maneira racional e de conformidade com os interesses da sociedade. A Lei de Responsaiblidade Fiscal, a par da Lei de Improbidade Administrativa, entre outras normas

\footnotetext{
${ }^{304}$ Idem. p. 153. O autor continua: “A transparência e a participação popular na gestão fiscal têm formação idealizada e inspirada no accountability, devendo servir para um controle de resultados e de adequação dos meios utilizados para o cumprimento da política fiscal, sem descurar do controle sobre o uso inadequado da discricionariedade". Idem. Ibidem.

${ }^{305}$ A transparência nos atos de governo é, também, reflexo da cidadania. Gianpaolo Poggio Smanio relaciona estes dois institutos - transparência e cidadania. Assevera o autor: "A dimensão da cidadania que deve ser desenvolvida é a dimensão horizontal, uma condição objetiva de acesso a direitos, mas também de comprometimento com os interesses da comunidade, como, por exemplo, a defesa ambiental, a responsabilidade social, a transparência dos negócios públicos, a distribuição de renda e a inclusão social". (grifos nossos). SMANIO, Gianpaolo Poggio. A conceituação... Op. cit. p. 337

${ }^{306}$ Dispõe o artigo 48, da Lei Complementar n 101/2000 (LRF): “Art. 48. São instrumentos de transparência da gestão fiscal, aos quais será dada ampla divulgação, inclusive em meios eletrônicos de acesso público: os planos, orçamentos e leis de diretrizes orçamentárias; as prestações de contas e o respectivo parecer prévio; o Relatório Resumido da Execução Orçamentária e o Relatório de Gestão Fiscal; e as versões simplificadas desses documentos. SÃO PAULO (SP). Lei Complementar $\mathrm{n}^{\circ} 101$, de 4 de maio de 2000. Lei de Responsabilidade Fiscal. Estabelece normas de finanças públicas voltadas para a responsabilidade na gestão fiscal e dá outras providências. Diário Oficial da União de 5 de maio de 2000.
} 
legais, balizaram o exercício das funções públicas, indicando caminhos para as boas práticas de administração". ${ }^{307}$

O princípio da transparência age, portanto, em prol do controle do poder político, na medida em que permite ao povo ter a fiel noção de como os recursos públicos estão sendo utilizados. Mais. Configura-se como importante instrumento de controle político, conferido ao povo. Helio Saul Mileski é quem explica:

\begin{abstract}
"Esse princípio constitui não só elemento de orientação, mas também de fiscalização quanto ao cumprimento dos objetivos orçamentários. É uma forma de controle político que está destinado ao controle social, na medida em que assegura ao cidadão a possibilidade de participar da elaboração dos planos de governo, procedendo a uma avaliação sobre a legalidade e eficiência dos atos de execução orçamentária". ${ }^{308}$ (grifos nossos)
\end{abstract}

Com efeito. É por meio da transparência que o povo adquire condições de controlar o poder político. De nada adiantam para a democracia medidas do governo que fiquem longe dos olhos do povo, impedindo-o de fiscalizar os atos estatais. Importante é que tais atos - especialmente quando envolvam dinheiro público, que pertence ao povo - sejam praticados sob a eterna vigilância popular, que poderá avalizar ou não o uso que se faz desse numerário, implicando a concordância ou não com a política pública adotada, o que constitui efetivo controle político da gestão pública.

Com a transparência, quem ganha é a democracia. Sobre o tema, assevera Cláudio Lembo:

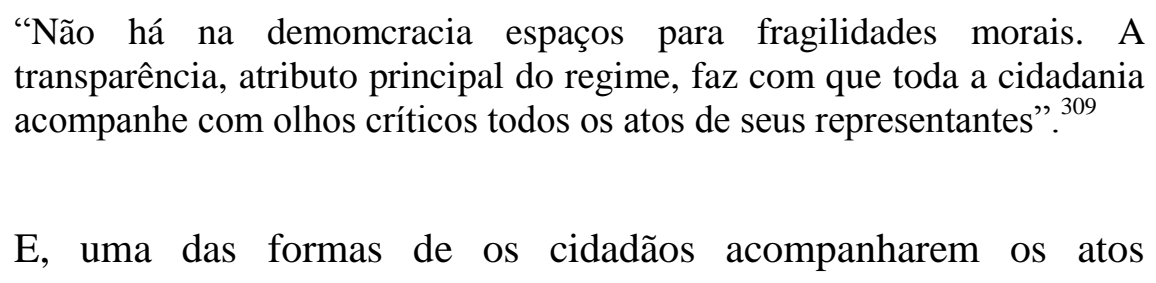
praticados pelos representantes - os Chefes do Executivo no caso -, é controlando o uso dos recursos públicos por meio da prestação de contas a que Presidente, Governador e Prefeito estão obrigados. Do mesmo modo, exige-se que os parlamentares fiscalizem os

${ }^{307}$ LEMBO, Cláudio. Eles temem a liberdade. Barueri, São Paulo: Minha Editora; São Paulo: CEPES, 2006. p. 6.

${ }^{308}$ MILESKI, Helio Saul. Op. cit. p. 153.

${ }^{309}$ LEMBO, Cláudio. Visões... Op. cit. p. 144. 
atos praticados pelo Executivo, o que significa, para este trabalho, julgar as contas prestadas pelo Chefe do Executivo. Cumpre-se, assim, a "relação de confiança", afirmada pelo eleitor nas urnas e evita-se que se tornem, os parlamentares, "representantes de si mesmos". 310

Esse acompanhamento, pelo Legislativo, se faz através do exercício do controle político dos atos praticados pelo Executivo. Vale dizer, é dever constitucional do Legislativo julgar as contas do Executivo.

O controle popular ou o controle social apresenta-se, portanto, como indiscutível instrumento para que o povo controle a utilização dos recursos públicos em prol da democracia, já que nesta o poder a ele pertence.

Em âmbito municipal, o mencionado controle popular ou social é coroado pelo disposto no $\S 3^{\circ}$ do artigo 31 da Constituição Federal, que estabelece que "as contas dos Municípios ficarão, durante 60 (sessenta) dias, anualmente, à disposição de qualquer contribuinte, para exame e apreciação, o qual poderá questionar-lhes a legitimidade, nos termos da lei". ${ }^{311}$ Como se vê, a própria Lei Maior confere instrumento ao contribuinte para fiscalizar as contas dos Municípios, vale dizer, o uso do dinheiro público. Sobre o tema, assevera ainda Hely Lopes Meirelles, que "a inexistência de lei específica sobre o assunto não impede o controle, que poderá ser feito através dos meios processuais comuns, como o mandado de segurança e a ação popular". 312

\footnotetext{
${ }^{310}$ É Cláudio Lembo que usa esta expressão. O autor, tratando da função de elaborar as leis e de fiscalizar os atos do Executivo, ambas típicas do Legislativo, assevera: "A esses [parlamentares] incube elaborar as leis e - insista-se - fiscalizar os atos do Executivo. O noticiário dos meios de comunicação demonstra exatamente o contrário. Os legisladores perderam-se em divagações bizantinas. Deixaram, assim, de atuar em suas efetivas funções. Uma lástima. Ao invés de legislar, homologam medidas provisórias. Quando deviam fiscalizar, esgrimam entre si.(...). Essa mesma conceituação [da democracia] se banaliza. Muitos já perguntam se a democracia deixou de ser o governo do povo pelo povo para se tornar o governo dos políticos para os políticos.Tornaram-se representantes de si próprios. Esquecem que receberam um mandato do povo para a defesa dos interesses do mandatário. Em uma operação exdrúxula, repete-se, tornaram-se representantes de seus próprios interesses". LEMBO, Cláudio. Visões... Op. cit. pp. 143-144.

${ }^{311}$ BRASIL. Constituição (1988). Constituição da República Federativa do Brasil: promulgada em 5 de outubro de 1988: atualizada até a Emenda Constitucional no 67, de 22-12-2010. 45 a ed. ampl. São Paulo: Saraiva, 2011. p. 40.

${ }^{312}$ MEIRELLES, Hely Lopes. Direito administrativo... Op. cit. p. 675.
} 


\subsubsection{Quanto ao momento em que o controle é realizado}

\subsubsection{Controle prévio, concomitante ou posterior}

Em relação ao momento de sua realização, o controle pode ser prévio (ou a priori ou preventivo), concomitante e posterior (ou a posteriori).

Prévio (ou a priori ou preventivo) é o controle que visa a evitar que um ato ilegal ou que fira o interesse público seja cometido. São exemplos constitucionais desse tipo de controle autorização prévia que o Congresso Nacional confere para que um referendo seja realizado (artigo 49, XV) ou a aprovação prévio pelo Senado Federal, por voto secreto, após audiência pública, de indicação de Ministro do Tribunal de Contas da União escolhido pelo Presidente da República (artigo 52, III, “b”), bem como a suspensão liminar, pelo Tribunal de Contas, de licitação que, em sede de representação, o entenda irregular, como, por exemplo, na hipótese de um edital que esteja inviabilizando a competitividade do certame.

Concomitante é o controle efetivado no momento em que o ato está sendo praticado, como por exemplo, a realização de uma auditoria, tanto na esfera dos Poderes, quanto a efetuada pelo Tribunal de Contas para verificar a regularidade de um ato ou examinar um contrato que está sendo executado.

Posterior (ou a posteriori) é o controle que visa a verificar se o ato praticado foi concretizado de maneira legal e constitucional para, na sua negativa, ser ele revisto, anulado ou desfeito e, caso tenha sido executado de maneira correta, para que seja confirmado. É o caso da homologação ou da revogação de um contrato.

Tanto o controle realizado pelo Poder Legislativo quanto o efetivado pelo Tribunal de Contas pode ser prévio, concomitante ou posterior.

\subsubsection{Quanto à finalidade}

\subsubsection{Controle de legalidade e de mérito}

Controle de legalidade é aquele que visa a verificar a conformação do ato com a lei, com a Constituição, com as instruções normativas, portarias, editais ou 
quaisquer outras normas que a Administração Pública deva cumprir. O controle que nesse sentido se faz é de legalidade ou de legitimidade e pode ser exercido pelos três Poderes ou, ainda, por órgãos como o Tribunal de Contas e o Ministério Público. A diferença quanto aos Poderes, explica Hely Lopes Meirelles ${ }^{313}$, é que o controle realizado pelo Poder Executivo é de ofício ou via recursal, o executado pelo Poder Legislativo é somente o que decorre de previsão constitucional e o efetuado pelo Poder Judiciário faz-se via ação judicial adequada. Além disso, "por este controle o ato ilegal ou ilegítimo só pode ser anulado e não revogado, como erroneamente se diz". ${ }^{314}$

Controle de mérito consiste no exame da eficiência, do resultado ou da conveniência e da oportunidade ${ }^{315}$ do ato praticado. Hely Lopes Meirelles ensina que ele "compete normalmente à Administração, e, em casos excepcionais, expressos na Constituição, ao Legislativo (CF, art. 49, IX e X), mas nunca ao Judiciário". ${ }^{316}$ No âmbito do Poder Legislativo, autoriza-se ao Parlamento o controle de mérito no caso dos incisos IX e X do artigo 49, os quais conferem ao Congresso Nacional, como competência exclusiva, respectivamente, o julgamento das contas prestadas pelo Presidente da República e a apreciação dos relatórios sobre a execução dos planos de governo e a fiscalização e controle, diretamente, ou por qualquer das Casas, dos atos do Poder Executivo, incluídos os da administração indireta.

\subsubsection{Quanto à iniciativa}

\subsubsection{Controle de ofício e por provocação}

Quanto à iniciativa, o controle pode ser de ofício ou por provocação.

De ofício é o controle que se inicia, sem a manifestação do interessado, diretamente pela Administração Pública, à qual compete, igualmente, dar

\footnotetext{
${ }^{313}$ Idem. p. 663.

${ }^{314}$ Idem. Ibidem

${ }^{315}$ Hely Lopes Meirelles ensina que "a verificação da eficiência e do resultado é de caráter eminentemente técnico, vinculada a critérios científicos, ao passo que o juízo de conveniência ou oportunidade é fundamentalmente político-administrativo e discricionário, razão pela qual o controle daquelas condições (eficiência e resultado) pode ser exercido por órgão especializado até mesmo estranho à Administração e o desta (conveniência e oportunidade) é privativo das Chefias do Executivo e, nos casos constitucionais, por órgãos do Legislativo em funções político-administrativas". (grifos nossos). Idem. Ibidem.

${ }^{316}$ Idem. Ibidem.
} 
andamento ao processo, de modo a realizar os atos processuais necessários ao desfecho do procedimento. Decorre do princípio da oficialidade, expresso no artigo $5^{\circ}$ da Lei federal $\mathrm{n}^{\mathrm{o}}$ 9.784, de 29 de janeiro de 1999, que dispõe que "o processo administrativo pode iniciar-se de ofício ou a pedido de interessado" 317 e pode ser realizado por qualquer dos Poderes, pelo Tribunal de Contas ou pelo Ministério Público. É o caso, por exemplo, das auditorias iniciadas pelo Tribunal de Contas ou pelo Poder Legislativo, tal como determina o artigo $71, \mathrm{IV}^{318}$, da Constituição Federal.

Por provocação é o controle cujo início depende da manifestação do interessado (o cidadão) ou, ainda, o deflagrado por um outro órgão, diferente daquele que será fiscalizado, como por exemplo, ainda no caso do inciso IV do artigo 71 da Constituição Federal, a auditoria solicitada pelo Congresso Nacional, uma de suas Casas ou Comissões ao Tribunal de Contas.

\subsubsection{Controle técnico}

Controle técnico é o controle orçamentário, que envolve os aspectos contábil, financeiro, orçamentário stricto sensu, operacional e patrimonial. Ives Gandra Martins ${ }^{319}$, em sua obra Comentários à Constituição do Brasil, escrita juntamente com Celso Ribeiro Bastos, ensina que na fiscalização orçamentária, considerada em seu sentido amplo, já se encontram as fiscalizações contábil, financeira, operacional e patrimonial. O mesmo autor aduz ainda que o controle do orçamento é técnico. Tratando do orçamento, diz ele: "sendo um instrumento técnico, jurídico, econômico e financeiro, abrange todas as previsões de receita e de despesas para o exercício, assim como a radiografia patrimonial da União". ${ }^{320}$ (grifos nossos)

\footnotetext{
${ }^{317}$ BRASÍLIA (BR). Lei federal no 9.784, de 29 de janeiro de 1999. Regula o processo administrativo no âmbito da Administração Pública Federal. Diário Oficial da União de 1 de fevereiro de 1999 e retificado em 11 de março de 1999

${ }^{318}$ Dispõe ao artigo 71, IV, da Constituição Federal:

Artigo 71: “O controle externo, a cargo do Congresso Nacional, será exercido com o auxílio do Tribunal de Contas da União, ao qual compete: IV - realizar, por iniciativa própria, da Câmara dos Deputados, do Senado Federal, de Comissão técnica ou de inquérito, inspeções e auditorias de natureza contábil, financeira, orçamentária, operacional e patrimonial, nas unidades administrativas dos Poderes Legislativo, Executivo e Judiciário, e demais entidades referidas no inciso II". BRASIL. Constituição (1988). Constituição da República Federativa do Brasil: promulgada em 5 de outubro de 1988: atualizada até a Emenda Constitucional $n^{\circ}$ 67, de 22-12-2010. 45 a ed. ampl. São Paulo: Saraiva, 2011. pp. 69-70.

${ }^{319}$ BASTOS, Celso Ribeiro; MARTINS, Ives Gandra. Comentários à Constituição do Brasil (promulgada em 5 de outubro de 1988). $3^{\text {a }}$ ed. atual. v. 4. Tomo II: arts. 70 a 91. São Paulo: Saraiva, 2002. p. 2.

${ }^{320}$ Idem. pp. 2-3.
} 
E este controle técnico é realizado pelo Tribunal de Contas. Ives Gandra Martins assim esclarece:

"De rigor, os aspectos técnicos são todos levantados pelo Tribunal de Contas, fornecendo seus pareceres ao Congresso Nacional que os acatará ou não, tendo, todavia, na atual Constituição, poder execucional superior àquele que detinha na ordem anterior, em determinadas hipóteses". ${ }^{321}$

De se ressaltar, como já foi dito, que não existe relação de subalternidade entre o Tribunal de Contas e o Poder Legislativo. Daí porque a citação do autor precitado deve levar em consideração que o encaminhamento dos pareceres do Tribunal de Contas ao Parlamento tem intuito apenas elucidativo, de comunicar à Casa do Povo, por exemplo, as auditorias que foram realizadas na área da saúde, constituindo exceção a remessa do parecer prévio das contas do governo (inciso I do artigo 70 da Constituição Federal), que deve ser anualmente enviado, em prazo determinado, para que o Poder Legislativo julgue essas contas.

De outro lado, ainda acerca do controle técnico, que pertence ao Tribunal de Contas, Francisco Eduardo Carrilho Chaves explana que "a medida da autonomia dos tribunais de contas varia de país para país, mas é uma característica marcante. Como regra, compete aos tribunais de contas julgar as contas de todos administradores públicos (julgamentos técnicos). Apenas julgamentos de caráter predominantemente político, como o caso de nossas Contas do Governo da República, são realizados pelo próprio titular do Controle Externo (leia-se parlamento no caso brasileiro)". 322

Como se vê, o autor diferencia o julgamento técnico, realizado pelo Tribunal de Contas, do julgamento político, este a cargo do Poder Legislativo. O julgamento político é fundamentado na conveniência e oportunidade, o que não se admite no controle técnico, já que, como verdadeiro controle jurídico, deve ser pautado pelo respeito à legalidade.

\footnotetext{
${ }^{321}$ Idem. pp. 13-14.

${ }^{322}$ CHAVES, Francisco Eduardo Carrilho. Op. cit. p. 12. É que o julgamento pelo Poder Legislativo é político.
} 


\subsubsection{Quanto à origem}

Quanto à origem, o controle pode ser interno ou externo "consoante decorra de órgão integrante ou não da própria estrutura em que se insere o órgão controlado". 323

\subsubsection{Controle interno}

Trata-se de controle administrativo e se apresenta como o "controle que cada um dos Poderes exerce sobre seus próprios atos e agentes". ${ }^{324}$ Efetua-se, assim, sobre a própria estrutura do órgão, seus agentes ou atividade. Pode ser realizado no âmbito da Administração Pública, dos Poderes Legislativo e Judiciário, do Tribunal de Contas, do Ministério Público e de quaisquer outros órgãos constitucionais ou não.

Conceitua-se, nos dizeres de Edmir Neto de Araújo, como o controle "exercido pela própria Administração, por seus órgãos, na relação de subordinação hierárquica, sobre seus próprios atos e agentes, ou por sistema de auditoria que acompanha as atividades, principalmente de legalidade da despesa pública". ${ }^{325}$

Cuidando-se da matéria referente ao controle financeiro fiscalização contábil, financeira, orçamentária, operacional e patrimonial - os três Poderes deverão realizar o controle interno, de acordo com a determinação do caput do artigo $70^{326}$ da Constituição Federal.

Além disso, o controle interno, nos termos do artigo 74 da Constituição Federal, traz especificações sobre como se processa este controle no âmbito dos Poderes Executivo, Legislativo e Judiciário e assim é porque os três Poderes deverão manter sistema de controle interno de forma integrada, de modo a proteger e a garantir a efetivação da matéria orçamentária, ou seja, objetiva verificar se as metas do plano

${ }_{323}^{323}$ DI PIETRO, Maria Sylvia Zanella. Direito... Op. cit. p. 692.

${ }^{324}$ Idem. Ibidem.

${ }^{325}$ ARAÚJO, Edmir Netto de. Curso de direito administrativo. $4^{\text {a }}$ ed. rev. e atual. S]ao Paulo: Saraiva, 2009. p. 1150 .

326 Dispõe o artigo 70, caput, da Constituição Federal: “A fiscalização contábil, financeira, orçamentária, operacional e patrimonial da União e das entidades da administração direta e indireta, quanto à legalidade, legitimidade, economicidade, aplicação das subvenções e renúncia de receitas, será exercida pelo Congresso Nacional, mediante controle externo, e pelo sistema de controle interno de cada Poder". (grifos nossos) BRASIL. Constituição (1988). Constituição da República Federativa do Brasil: promulgada em 5 de outubro de 1988: atualizada até a Emenda Constitucional no 67, de 22-12-2010. 45 ed. ampl. São Paulo: Saraiva, 2011. p. 69 . 
plurianual estão sendo cumpridas; se os programas de governo e dos orçamentos da União (e das demais esferas federativas) estão sendo executados; comprovar a legalidade e avaliar os resultados, no tocante à eficácia e à eficiência das gestões orçamentária, financeira e patrimonial nos órgãos e entidades dos entes federativos, bem como da aplicação dos recursos por entidades de direito privado; exercer o controle das operações de crédito, avais e garantias, assim como dos direitos e haveres nos entes da federação; e apoiar o controle externo no desempenho de sua função.

\subsubsection{Controle externo}

O controle externo, por sua vez, é o concretizado por um órgão diferente daquele onde o controle será exercido ou, como acrescenta Maria Sylvia Zanela Di Pietro, traduz-se também pelo "controle da Administração Direta sobre a Indireta".327 Aduz, ainda, Eduardo Lobo Botelho Gualazzi que “pode-se dizer, em linguagem alegórica, que o controle externo é o controle dos controles, inclusive porque lhe cabe controlar os próprios órgãos que realizam as outras formas de controle, não podendo ser por estes controlado". 328 (grifos do autor)

Em matéria orçamentária, o controle externo é realizado pelo Poder Legislativo (Congresso Nacional, Assembleias Legislativas ou Câmara Distrital e Câmara dos Vereadores nas três esferas federativas) e está previsto no artigo 70, caput da Constituição Federal, competindo-lhe realizar o controle financeiro, que engloba, como se disse, a fiscalização contábil, financeira, orçamentária, operacional e patrimonial da União e das entidades da administração direta e indireta, quanto aos aspectos da legalidade, da legitimidade, da economicidade, da aplicação das subvenções e da renúncia de receitas.

Além disso, para a realização deste controle, o Poder Legislativo conta, na legenda constitucional, com o auxílio de um órgão, o Tribunal de Contas, cujas competências, expressas nos incisos do artigo 71, vão desde apreciar, para fins de registro, a legalidade dos atos de admissão pessoal da administração direta ou indireta; proceder a auditorias de natureza financeira, cujos resultados podem ser, caso solicitados, informados ao Poder Legislativo respectivo, até julgar as contas dos administradores públicos, à exceção das do Chefe do Executivo, pois para estas o Tribunal de Contas elabora um

\footnotetext{
${ }^{327}$ DI PIETRO, Maria Sylvia Zanella. Direito... Op. cit. p. 692.

${ }^{328}$ GUALAZZI, Eduardo Lobo Botelho. Op. cit. p. 33.
} 
parecer prévio que contenha, pelo menos ${ }^{329}$, a apreciação técnica das contas e o encaminha para julgamento na sede da Casa de Leis respectiva.

Ou seja, por meio do controle externo, o Poder Legislativo pretende investigar, com o auxílio do Tribunal de Contas, como o dinheiro público foi gasto pelo Chefe do Executivo (Presidente da República, Governador do Estado ou do Distrito Federal e Prefeito). Trata-se, pois, de um Poder - o Legislativo - com o auxílio de um órgão - o Tribunal de Contas - controlando a destinação dada aos recursos públicos pelo Poder Executivo.

E por qual motivo foi atribuída ao Poder Legislativo, com o auxílio do Tribunal de Contas, a realização do controle financeiro?

A explicação está no fato de que os integrantes desse Poder representam o povo, que é o verdadeiro "dono" do dinheiro público, de modo que as justificativas de seu uso devem a ele ser prestadas, através de seus representantes, que compõem o Poder Legislativo. Ocorre que o julgamento político é precedido de uma fase técnica, atribuída ao Tribunal de Contas. José Afonso da Silva bem explica esta relação e o faz conceituando o controle externo. Preleciona o Mestre:

\footnotetext{
"Consiste, assim [o controle externo], na atuação da função fiscalizadora do povo, através de seus representantes, sobre a administração financeira e orçamentária. É, portanto, um controle de natureza política, no Brasil, mas sujeito à prévia apreciação técnico-administrativa do Tribunal de Contas competente, que, assim, se apresenta como órgão técnico, e suas decisões são administrativas, não jurisdicionais, como, às vezes, se sustenta, à vista da expressão 'julgar as contas' referida à sua atividade (art. 71, II)".330 (grifos nossos)
}

Somam-se, assim, as tarefas do Tribunal de Contas (técnica) com a do Poder Legislativo (política). Este último, órgão político por excelência, é que realiza o

\footnotetext{
${ }^{329}$ Diz-se "pelo menos" porque nossa tese pretende avaliar se o Tribunal de Contas, ao apreciar as contas do Prefeito também não estaria praticando um controle político ao invés do controle somente técnico. Para detalhes consultar o item 5.4 (Há controle político quando o Tribunal de Contas elabora o parecer prévio apreciando as contas de governo apresentadas pelo Prefeito?).

${ }^{330}$ SILVA, José Afonso da. Curso... Op. cit. pp. 752-753. Quanto ao "julgamento das contas”, expressão inserta no inciso II do artigo 71 da Constituição Federal, o autor reforça que ela também está prevista no inciso IX do artigo 49 quando estabelece competir ao Congresso Nacional julgar anualmente as contas do Presidente da República sem que, também nesta hipótese, signifique que o Poder Legislativo tenha natureza judicante.Para detalhes, consultar: SILVA, José Afonso da. Curso de direito constitucional positivo. $25^{\mathrm{a}}$ ed. rev. e atual. São Paulo: Malheiros, 2005. p. 753.
} 
controle político anteriormente estudado, isto é, a fiscalização constitucional dos atos praticados pelo Poder Executivo, neste caso, especificamente os relacionados às receitas e às despesas públicas, inclusive o modo como foram utilizadas essas receitas.

De outro lado, o Tribunal de Contas, enquanto órgão que realiza o controle técnico, exerce o controle das contas públicas e não pode ser dispensado ou excluído do cenário pátrio, daí porque não se pode dizer, em nosso entendimento, que o controle externo, referido no artigo 70 da Constituição é realizado pelo Poder Legislativo, apenas. Pensamos que seja tarefa compartilhada atribuída a um Poder - o Legislativo - e a um órgão - o Tribunal de Contas. Desta relação falaremos mais nos Capítulos IV e V.

Daí porque entendemos que esta "soma" das tarefas do Poder Legislativo com as do Tribunal de Contas representa a linha mestra de nossa tese: a relação entre o Poder Legislativo e o Tribunal de Contas, no controle das contas públicas, constitui, na verdade, uma relação de cooperação e não da interação entre um órgão principal (o Poder Legislativo) e um órgão auxiliar, subalterno (o Tribunal de Contas). Mas disto trataremos no Capítulo IV e V.

Após a análise da Entidade de Fiscalização Superior (EFS) brasileira, que é o Tribunal de Contas, bem como dos tipos de controle do poder existentes no Brasil abordaremos, no Capítulo seguinte, especificamente, o controle externo em âmbito municipal. Para tanto, são destacados os dois órgãos- na verdade um Poder (a Câmara dos Vereadores) e um órgão (o Tribunal de Contas) - que são os responsáveis pelo controle das contas públicas em âmbito municipal. O objetivo do Capítulo é, pois, trazer à colação os aspectos mais importantes pelos quais o Poder e o órgão desempenham suas atividades de controle externo das contas públicas municipais. 


\section{CAPÍtulo IV: O DEVER DE PRESTAR CONTAS E O CONTROLE EXTERNO DAS CONTAS MUNICIPAIS NA CONSTITUIÇÃO FEDERAL DE 1988}

\subsection{A prestação de contas na Constituição Federal Brasileira de 1988}

No ordenamento pátrio, a Constituição Federal de 1988 reserva a Seção IX - "Da Fiscalização Contábil, Financeira e Orçamentária”, do Capítulo I - "Do Poder Legislativo", do Título IV - "Da Organização dos Poderes" para cuidar da fiscalização contábil, financeira, orçamentária, operacional e patrimonial a ser exercida pelos sistemas de controle interno de cada Poder e pelo sistema de controle externo, este a cargo do Congresso Nacional (artigo 70, caput). O controle externo é, ainda, realizado com o auxílio do Tribunal de Contas (artigo 71, caput), órgão técnico responsável pelo controle das contas públicas.

Acerca especificamente do dever de prestar contas, cuida a Lei Maior da questão no parágrafo único do artigo 70, determinando quais são as pessoas obrigadas a prestar contas: “prestará contas qualquer pessoa física ou jurídica, pública ou privada, que utilize, arrecade, guarde, gerencie ou administre dinheiros, bens e valores públicos ou pelos quais a União responda, ou que, em nome desta, assuma obrigações de natureza pecuniária". 331

O que se verifica é que a abrangência dos legitimados a prestar contas é ampla e envolve "qualquer pessoa" - física ou jurídica. Mas, para que esta esteja obrigada a prestar contas, é imprescindível que pratique uma das ações - utilizar, arrecadar, guardar, gerenciar ou administrar bens e valores públicos - insertas no parágrafo único do artigo 70 da Constituição Federal. Não são, portanto, "todas as pessoas" que estão obrigadas a prestar contas e sim todo gestor público, englobando, como se disse, tanto o funcionário público quanto o agente político, este último na figura do Prefeito ou na de um Secretário de Governo. Todos que utilizarem dinheiro público devem prestar contas.

331 BRASIL. Constituição (1988). Constituição da República Federativa do Brasil: promulgada em 5 de outubro de 1988: atualizada até a Emenda Constitucional nº 67, de 22-12-2010. 45a ed. ampl. São Paulo: Saraiva, 2011. p. 69. 


\subsection{A prestação de contas pelo Prefeito}

É preciso consignar que o Estado, para conseguir cumprir os seus objetivos, necessita de dinheiro. É com ele que o Estado contrata, paga os empregados, realiza licitações e etc, ou seja, “o Estado realiza despesas, seja para custear a máquina administrativa seja para constituir um patrimônio. Receita e despesa são, portanto, a base de toda a gestão financeira e patrimonial do Estado". 332

O Estado precisa, pois, de recursos para a obtenção de suas finalidades. Ocorre que o dinheiro não lhe pertence. Em um Estado Democrático de Direito pertence ao povo. É por isso que os parlamentares, enquanto representantes do povo, votam o orçamento, estabelecendo quando e onde os gastos públicos deverão ocorrer, tudo com o intuito de promover o bem-comum. Unem-se, assim, os Poderes Legislativo e Executivo em prol de realizações como, por exemplo, a construção de escolas, creches, hospitais, parques, tudo para promover o bem-estar social, que é um dos objetivos da ordem social brasileira (artigo $193^{333}$ da Constituição Federal).

No entanto, não basta apenas que o Poder Legislativo controle previamente - por meio da lei orçamentária - como o dinheiro público será empregado. O controle deve ser em todas as etapas da utilização do dinheiro público e, inclusive, na posterior, a fim de verificar se ele foi bem empregado. O dinheiro público é, pois, controlado prévia, concomitante e posteriormente.

E a quem compete, então, a função de controle dos gastos públicos? Ao Poder Legislativo, não há dúvidas, por ser ele um órgão de controle. Lembramos, aqui, que duas de suas funções típicas, que serão melhor estudadas nos tópicos seguintes, são exatamente a de controle político e a de poder financeiro. E esta última é realizada com o auxílio do Tribunal de Contas, que se classifica como uma "Entidade de Fiscalização Superior".

Devemos destacar, por oportuno, como já analisado, que em cenário mundial existem as tais "Entidades de Fiscalização Superior" ou as "Instituições

\footnotetext{
332 AGUIAR, Afonso Gomes; AGUIAR, Márcio Paiva de. Op. cit. p. 13.

${ }^{333}$ Dispõe o artigo 193 da Constituição Federal: "Art. 193. A ordem social tem como base o primado do trabalho, e como objetivo o bem-estar e a justiça sociais”. BRASIL. Constituição (1988). Constituição da República Federativa do Brasil: promulgada em 5 de outubro de 1988: atualizada até a Emenda Constitucional no 67, de 22-12-2010. 45ª ed. ampl. São Paulo: Saraiva, 2011. p. 144
} 
Supremas de Controle", cujo cerne é a realização do controle dos gastos públicos, ora em auxílio ao Legislativo, como no Brasil, ora por meio de uma Controladoria Geral, que é um órgão monocrático e ora inseridas na estrutura do Poder Judiciário, mas todas elas com um traço comum: o controle de como o dinheiro público é gasto pelo Estado.

\section{Com esta estrutura - Poder Legislativo e "Entidade de Fiscalização} Superior" - controlando o modo como o Prefeito utiliza o dinheiro público, além de se colocar em prática os freios e contrapesos de Montesquieu, garante-se, ainda, ao povo, no Estado Democrático de Direito e republicano, o conhecimento de como o dinheiro será, está sendo e foi empregado, resultando, se necessário, nas responsabilizações política ${ }^{334}$, civil ou penal ${ }^{335}$ do Prefeito no caso de má versação do dinheiro público.

São estes os motivos que fazem a prestação de contas por parte do Prefeito ser imprescindível em um Estado Democrático de Direito. E isto porque, como todo o poder pertence ao povo, o uso e a destinação do dinheiro público por ele devem ser fiscalizados. Em última análise, é ao povo que aquele que exerce o poder político, no caso específico o Chefe do Poder Executivo, deve prestar contas. Entretanto, como a tarefa é impossível de ser realizada diretamente, ela se faz indiretamente, perante os representantes por ele eleitos. Este é mais um dos motivos pelos quais a prestação de contas é atribuição do Poder Legislativo, eis que é no Parlamento que se encontram os representantes do povo.

\footnotetext{
${ }^{334}$ A responsabilidade política é fruto da representação política e, em ambiente republicano, como o Brasil, se apura nas urnas, em âmbito municipal, mediante a reeleição ou não do Prefeito ou, terminado o seu mandato, com sua eleição ou não para outro cargo político. A inabilitação para concorrer às funções públicas por oito anos ou, ainda, a perda ou suspensão do cargo também são exemplos de responsabilidade política. É o que decorre da Lei Complementar $n^{\circ}$ 64/90 com redação dada pela Lei Complementar $n^{\circ} 135 / 10$. Com efeito, se uma representação contra o Prefeito, por má versação do dinheiro público, for julgada procedente na Justiça Eleitoral, a consequência será a sua responsabilização, que consiste: na declaração de inelegibilidade por oito anos subseqüentes ou na cassação do registro ou do diploma do candidato. É o que dispõe o inciso XIV do artigo 22 da Lei Complementar $n^{\circ}$ 64/90 com redação dada pela Lei Complementar $\mathrm{n}^{\circ}$ 135/10: “Art. 22: (...) poderá representar à Justiça Eleitoral, (...) relatando fatos e indicando provas, indícios e circunstâncias e pedir abertura de investigação judicial para apurar uso indevido, desvio ou abuso do poder econômico ou do poder de autoridade, ou utilização indevida de veículos ou meios de comunicação social, em benefício de candidato ou de partido político, obedecido o seguinte rito: XIV - julgada procedente a representação, ainda que após a proclamação dos eleitos, o Tribunal declarará a inelegibilidade do representado e de quantos hajam contribuído para a prática do ato, cominando-lhes sanção de inelegibilidade para as eleições a se realizarem nos 8 (oito) anos subsequentes à eleição em que se verificou, além da cassação do registro ou diploma do candidato diretamente beneficiado pela interferência do poder econômico ou pelo desvio ou abuso do poder de autoridade ou dos meios de comunicação, determinando a remessa dos autos ao Ministério Público Eleitoral, para instauração de processo disciplinar, se for o caso, e de ação penal, ordenando quaisquer outras providências que a espécie comportar". BRASÍLIA (BR). Lei Complementar n 64, de 18 de maio de 1990. Estabelece, de acordo com o art. 14, $\S 9^{\circ}$ da Constituição Federal, casos de inelegibilidade, prazos de cessação, e determina outras providências. Diário Oficial da União de 21 de maio de 1990.

${ }^{335}$ As responsabilizações civis e penais estão previstas nos Códigos Civil e Penal.
} 
Vale dizer, aquele que utilizou dinheiro público deve prestar contas de tal uso ao Legislativo, que é o órgão político por excelência e perante o qual as contas do Chefe do Executivo, que utiliza esses recursos públicos, serão julgadas. Trata-se, pois, de julgamento político do Chefe do Executivo, a cargo do Poder Legislativo.

Ressalte-se, como já foi dito, que para exercer esta função típica de controle do poder político, o Poder Legislativo conta com o dito auxílio de um intermediário: o Tribunal de Contas. Assim, a prestação de contas do Prefeito é entregue ao Tribunal de Contas, que elabora um parecer prévio sobre as contas do governo, votando-o e, depois, o encaminha à análise do Poder Legislativo, que, julgando-as, fará incidir ou não a responsabilidade política.

Passamos, em seguida, ao estudo das formas de controle do Poder Legislativo.

\subsection{Do Poder Legislativo municipal e suas funções}

Antes de entrarmos especificamente no estudo do controle das contas municipais, é preciso tecer algumas considerações sobre as funções típicas do Poder Legislativo, na medida em que este Poder tem participação primordial no julgamento das contas do Prefeito, já que a ele compete a palavra final, aprovando o parecer prévio elaborado pelo Tribunal de Contas ou rejeitando-o, mas, nesta última hipótese, necessitando, para tal, do voto de dois terços dos seus membros.

Assim, em que pese seja a função legislativa desse Poder a mais conhecida, não é a única. São, também, funções típicas do Poder Legislativo: a representação política, a deliberativa, a eleitoral ${ }^{336}$, a jurisdicional, a de poder financeiro e a de controle político. As duas últimas, porque relacionadas à função de controle externo

\footnotetext{
${ }^{336}$ A função eleitoral é a única inexistente em âmbito municipal já que somente a União federal pode, de maneira privativa, legislar sobre direito eleitoral (artigo 22, I, da Constituição Federal). Não obstante, em âmbito federal esta função faz com que o Poder Legislativo, nas palavras de Monica Herman Salem Caggiano, "assuma o papel de corpo eleitoral", substituindo, assim, o povo na escolha dos representantes ou do Governo. Esta função é mais forte no parlamentarismo, já que lá é o Parlamento que elege o Chefe de Governo (Primeiro Ministro ou o Chanceler), ou seja, através desta função, o Poder Legislativo controla o Governo, já que àquele competirá a escolha dos membros que comporão o Governo. No ordenamento brasileiro vigente, de cunho presidencialista, o Congresso Nacional assume a competência eleitoral no caso de vacância, nos dois últimos anos do mandato presidencial, dos cargos de Presidente e de Vice-Presidente da República, competindo-lhe, na forma da lei, a eleição indireta dos novos dirigentes do país, consoante disposto no $\S 1^{\circ}$ do artigo 81 da Constituição Federal de 1988. CAGGIANO, Monica Herman Salem. Direito... Op. cit. p. 25.
} 
que o Poder Legislativo exerce em relação aos atos do Poder Executivo, serão objeto de nossa análise pormenorizada no item seguinte.

Passamos, então, inicialmente, a tratar, de maneira geral, de cada uma das funções típicas do Poder Legislativo.

A primeira das funções do Parlamento foi a de representação política $^{337}$, que consiste em uma forma de "participação do povo no poder"338, conforme explica Luis Sanchez Agesta. Ou seja, através da representação política, o povo participa, por meio de seus representantes, da tomada das decisões políticas do Estado. Dessa forma, quando os representantes exercem as suas funções típicas ou atípicas, eles não agem em nome próprio e sim em nome do povo.

Daí porque Manoel Gonçalves Ferreira Filho explica que a representação política consiste em um "vínculo entre os governados e os governantes pelo qual estes agem em nome daqueles e devem trabalhar pelo bem dos representados e não pelo próprio". 339

A representação política tem, pois, duas consequências: a primeira é a de permitir que o povo participe das decisões políticas, que são manifestações do Estado soberano. A segunda diz respeito ao dever que os representantes têm de prestar contas de seus atos aos governados o que, em última análise, é aferido nas urnas. É o que profere Monica Herman Salem Caggiano, "o povo, destarte, pronuncia-se através do processo eleitoral, selecionando seus representantes para, em seu lugar, assumirem o

\footnotetext{
${ }^{337}$ Acerca da representação política, explica Karl Loewentein: "Cualquiera que haya sido el origen de la técnica de la representación, fue en todo caso la condición previa e indispensable para distribuir el poder político entre diferentes detentadores del poder". O autor aduz, ainda, que são quatro os detentores do poder: o Parlamento, o Governo, os Tribunais Judiciários e o eleitorado. LOEWENSTEIN, Karl. Op. cit. p. 59. O que o autor quer dizer é que a representação política é uma forma de controlar o poder político. Vale dizer, quando aquela não existia o poder apresentava-se concentrado nas mãos do governante, que reunia as funções legislativa, executiva e judiciária. Com o aparecimento da representação política e considerando-a no cenário de um Estado Democrático de Direito, o Parlamento se separa do Governo, passando a ser, junto com este, um dos detentores do poder. Além disso, como o Parlamento representa o povo, também este último aparece como outro detentor do poder. E como se controla o poder político neste Estado Democrático de Direito? Distribuindo o seu exercício entre os diversos detentores do poder, na visão de Karl Loewenstein. Ou seja, diversos polos passam a exercer o poder ao mesmo tempo, sendo necessário o desenvolvimento de técnicas de controle deste poder.

${ }^{338}$ AGESTA, Luis Sanchez. Op. cit. p. 227.

${ }^{339}$ FERREIRA FILHO, Manoel Gonçalves. Curso... Op. cit. p. 86.
} 
domínio da gestão dos negócios públicos, reservando-se o direito de não reelegê-los na hipótese de não ver os seus anseios e expectativas satisfeitos". 340

Outra função típica é a legislativa, que não é a mais antiga do Parlamento, datando do século $\mathrm{XV}^{341}$ o seu nascimento. É, porém, a mais conhecida que, inclusive, dá nome ao órgão.

Ela é também anterior à separação de Poderes de Montesquieu. O que a teoria desejou foi proteger a liberdade e controlar os abusos praticados pelo governante e assim, conferiu como função típica, ao Poder Legislativo, a elaboração das leis que, no entanto, para serem formuladas, dependiam da manifestação das duas classes sociais que deveriam estar presentes no Parlamento, como dois corpos distintos: de um lado, a nobreza, de modo vitalício e, de outro, os representantes do povo. Estes "corpos", ainda, deveriam se controlar mutuamente (freios e contrapesos). Daí porque a explicação de Montesquieu sobre a tarefa de criar as leis: "O corpo representante tampouco deve ser escolhido para tomar alguma decisão ativa, coisa que não faria direito, mas para fazer leis, ou para ver se foram bem executadas aquelas que fez, coisa que pode muito bem fazer e, até mesmo, só ele pode fazer bem". 342

Em âmbito municipal, a função legislativa é desempenhada pela Câmara dos Vereadores com a participação do Prefeito, seja através das matérias de sua iniciativa, seja pela sanção e veto das leis que são de competência do Município, como por exemplo, as matérias sobre assuntos de interesse local (artigo 30, I, da Constituição Federal) ou as relacionadas à política urbana municipal (artigo 182, da Constituição Federal). Hely Lopes Meirelles assevera, com acertada razão, que a competência

\footnotetext{
340 CAGGIANO, Monica Herman Salem. Sistemas eleitorais x representação política. São Paulo: [s.n.], 1987. p. 19.

${ }^{341}$ A competência para elaborar a lei foi uma conquista somente do século XV quando, no ano de 1462 "passa o parlamento britânico a contar com a possibilidade de apresentar, diretamente, por seus membros, as 'Bills' (leis), as quais, à medida que houvesse acordo entre as duas casas, deveriam ser aprovadas pelo Rei. A partir desse momento, a ele restava, tão-só, promulgar o texto". CAGGIANO, Monica Herman Salem. Direito... Op. cit. p. 12. No mesmo sentido, Manoel Gonçalves Ferreira Filho explica que "o poder de votar as regras jurídicas - as leis - foi, em realidade, conquistado por essas Câmaras, na Inglaterra, a 'mãe dos Parlamentos', por meio de uma barganha: o consentimento em impostos em troca da extensão de sua influência na função legislativa. Em razão desse poder financeiro, conta o Legislativo com um auxiliar, o Tribunal de Contas" (grifos nossos). FERREIRA FILHO, Manoel Gonçalves. Curso... Op. cit. p. 160.

${ }^{342}$ MONTESQUIEU, Charles-Louis de Secondat, Baron de La Brède et de. O espírito das leis. Apresentação de Renato Janine Ribeiro. Tradução de Cristina Murachco. $3^{\mathrm{a}}$ ed. São Paulo: Martins Fontes, 2005. p. 171.
} 
legislativa para elaborar a Lei Orgânica municipal "enriqueceu sobremaneira a função legislativa da Câmara Municipal".343

A função deliberante significa que todas as decisões do Poder Legislativo, antes de serem tomadas, devem ser discutidas e deliberadas pelo órgão, de modo a propiciar o amplo debate sobre a matéria. E como o Poder Legislativo reúne os representantes do povo, ao final é este que estará participando das decisões políticas do país. Monica Herman Salem Caggiano assevera que "debates, votos e deliberações constituem os instrumentos específicos da atividade parlamentar". ${ }^{344}$ No Brasil, a função deliberante é efetivada, por exemplo, após o Prefeito prestar suas contas anuais à Câmara dos Vereadores, que deverá deliberar sobre as mesmas e decidir se as aprova ou rejeita (artigo 84, XXIV, da Constituição Federal que, por simetria, aplica-se ao ente federativo municipal). Entram nesta função, ainda, todas as matérias que são de competência privativa da Câmara e que independem da sanção do Prefeito, como "a prática de atos concretos, de resoluções referendárias, de aprovação, de autorização, de fixação de situações, de julgamento técnico"345, nas palavras de José Afonso da Silva.

No que tange à função jurisdicional, implica conferir ao Parlamento a possibilidade de, em casos específicos, solucionar conflitos ${ }^{346}$. O maior exemplo, no cenário brasileiro, em que esta função jurisdicional aparece é o impeachment. Em âmbito municipal, trata-se do impeachment do Prefeito, que poderá perder o seu mandato nos termos do artigo $28, \S 1^{\circ}$, da Constituição Federal, consoante determina o artigo 29, $\mathrm{XIV}^{347}$ também da Lei Maior. Igualmente, podem sofrer impeachment o VicePrefeito e os próprios Vereadores pela prática de infrações político-administrativas ${ }^{348}$. Trata-se, pois, no impeachment, de controle político por meio da função jurisdicional.

343 MEIRELLES, Hely Lopes. Direito municipal brasileiro. $10^{\mathrm{a}}$ ed. atual. por Izabel Camargo Lopes Monteiro e Célia Marisa Prendes. São Paulo: Malheiros, 1998. p. 458.

${ }^{344}$ CAGGIANO, Monica Herman Salem. Direito... Op. cit. p. 17.

345 SILVA, José Afonso da. Curso... Op.cit. p. 646.

${ }^{346}$ Em alguns países a tarefa consiste no julgamento da matéria eleitoral. Não é o caso do Brasil, cuja competência eleitoral é reservada à Justiça Eleitoral.

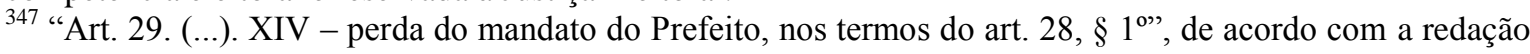
dada pela Emenda Constitucional no 19, de 4 de junho de 1998. BRASIL. Constituição (1988). Constituição da República Federativa do Brasil: promulgada em 5 de outubro de 1988: atualizada até a Emenda Constitucional no 67, de 22-12-2010. 45ª ed. ampl. São Paulo: Saraiva, 2011. p. 38.

348 José Nilo de Castro ensina que é a Câmara Municipal que julga o Prefeito pela prática das infrações político-administrativas. Entende, ainda, que o Decreto-lei no 201, de 27 de fevereiro de 1967 foi recepcionado pela Constituição de 1988. Nas palavras do autor: "E, ademais, (...) não encontramos razões ou argumentos de ordem jurídica capazes de demonstrar a contrariedade do disposto nos artigos $4^{\circ}$ e $5^{\circ}$ do Decreto-lei n. 201, de 27 de fevereiro de 1967, à atual Constituição Federal. É que os mesmos motivos 
Por fim, a função de comunicação com os representados é inerente à atividade parlamentar, vez que seus membros precisam estar em contato com aqueles que os elegeram, bem como com toda a coletividade, a fim de obterem votos e serem eleitos ou reeleitos.

Vistas algumas das funções típicas do Poder Legislativo, passamos, em seguida, à análise da forma pela qual o Poder Legislativo ganhou novamente destaque em cenário mundial: através da sua função de controle, que engloba os controles financeiro e político, diretamente relacionados com a nossa tese.

\subsubsection{A preponderância da função de controle}

Antes de adentrarmos nas funções típicas dos controles financeiro e político é preciso esclarecer que o Poder Legislativo teve dois momentos áureos no cenário político mundial: o primeiro, fruto da elaboração das leis e o segundo, resultado da função de controle.

Por meio da elaboração das leis no período liberal do Estado de Direito, nos séculos XVIII e XIX, o Parlamento alcançou sua fase áurea, na medida em que as leis, derivadas da Constituição, serviram efetivamente para limitar o poder real. Acerca do destaque do Poder Legislativo, profere Manoel Gonçalves Ferreira Filho, "a lei, expressão da vontade geral, é que rege o Estado; sujeita o Executivo ao cumprimento estrito do que a lei determina - este só pode fazer o que a lei permite; impõe ao Judiciário vivenciar a lei, decidindo os litígios, punindo os criminosos, mas sempre num processo dialético - o contencioso". ${ }^{349}$ Em outra obra, o mesmo autor, agora discorrendo sobre a preponderância do princípio da legalidade, explica que este "determina o proceder do Executivo, que nada pode senão de acordo com a lei. Igualmente, predetermina a ação do Judiciário. Este julga segundo a lei". 350

jurídicos que, no regime constitucional anterior, sustentavam a constitucionalidade do Decreto-lei n. 201/67, no particular, quando os Estados tinham o poder de organizar os Municípios, encontram-se presentes, atualizadíssimos, com a organização municipal conferida ao próprio Município. Lá e cá, o STF não se pronunciou contrariamente sobre essa tese. E o STF é o único intérprete da Constituição, com latitude". CASTRO, José Nilo de. Direito municipal positivo. $7^{\mathrm{a}}$ ed. rev. e atual. Belo Horizonte: Del Rey, 2010. p. 132.

${ }^{349}$ FERREIRA FILHO, Manoel Gonçalves. Poder... Op. cit. p. 191.

${ }^{350}$ FERREIRA FILHO, Manoel Gonçalves. A democracia no limiar do século XXI. São Paulo: Saraiva, 2001. pp. 120-121. 
A fase áurea é substituída, no século XX, pela decadência ${ }^{351}$ na produção legislativa. Isto porque o Poder Legislativo não conseguiu produzir leis para abranger as novas demandas que surgiam na sociedade e que se referiam à proteção dos direitos sociais, econômicos e culturais da classe proletária. Tal proteção requeria a adoção de políticas públicas, que exigiam a intervenção do Estado, fazendo florescer junto ao povo a figura do Presidente da República, enquanto Chefe do Executivo, como o único capaz de concretizar tais medidas.

Monica Herman Salem Caggiano aduz, no entanto, que o reaparecimento do Poder Legislativo deu-se com o surgimento da função de controle político. Nas palavras da autora, "o reingresso do Legislativo como organismo de relevância no cenário político acabou se operando na década de 1990, ressurgindo por intermédio da sua tarefa de controle político". ${ }^{352}$ A mesma autora, em outra obra, assevera “inobstante o ressurgir dos Parlamentos em cenário político, fortemente pelo viés do controle, a restauração do poder do Legislativo - a se contrapor ao Executivo - manteve-se como tema a instigar e desafiar os analistas". 353

Visto este panorama geral acerca de como o Poder Legislativo voltou a ser o centro das atenções em cenário mundial, passamos, em seguida, a estudar as ações de controle da Câmara Municipal. Assim é que, dentre as suas diversas funções ${ }^{354}$, duas são de controle externo sobre os atos do governo e merecem estudo pormenorizado: as funções de controle financeiro e de controle político.

\footnotetext{
351 Alguns momentos da história registram a decadência do Parlamento e, como consequência, o fortalecimento do Executivo. São eles os pós guerras mundiais, que instauraram grandes crises econômicas e políticas e o crescimento do comunismo, especialmente no Leste Europeu. Nestes períodos a principal tarefa do Parlamento - fazer as leis - foi ofuscada. Para maiores detalhes, consultar: CAGGIANO, Monica Herman Salem. Direito... Op. cit. p. 4.

352 Idem. p. 20.

${ }^{353}$ CAGGIANO, Monica Herman Salem. A emergência... Op. cit. p. 101.

${ }^{354}$ José Afonso da Silva explica que são quatro as funções da Câmara Municipal: 1) a função legislativa, que se apresenta por meio das leis municipais por ela aprovadas e sancionadas pelo Prefeito. As matérias de competência legislativa da Câmara Municipal estão disciplinadas na Lei Orgânica do Município; 2) a função meramente deliberativa através da qual a Câmara Municipal exerce as suas competências privativas e apresenta-se na forma de "atos concretos, de resoluções referendárias, de aprovação, de autorização, de fixação de situações, de julgamento técnico, que independem da sanção do Prefeito, as quais também deverão ser indicadas pela lei orgânica própria"; 3) a função fiscalizadora, representada pela fiscalização financeira e orçamentária do Município, que se desenvolve com o auxílio do Tribunal de Contas do Estado, do Tribunal ou Conselho de Contas ou do Tribunal de Contas do Município de São Paulo ou do Rio de Janeiro. Também faz parte desta função fiscalizadora a atuação dos cidadãos, na medida em que as contas do Município deverão ficar, durante sessenta dias, à disposição dos cidadãos, que poderão questionar a sua legitimidade, na forma da lei, consoante determina o $\$ 3^{\circ}$ do artigo 31 da Constituição Federal e; 4) a função julgadora, quando exerce o controle político, ao julgar os Prefeitos e Vereadores pelas infrações políticoadministrativas. SILVA, José Afonso da. Curso... Op. cit. pp. 646-647.
} 
Examinemos cada uma delas.

\subsubsection{A função de controle financeiro ${ }^{355}$}

Uma das primeiras funções típicas do Poder Legislativo foi a de poder financeiro, isto é, a competência privativa para instituir impostos, como uma forma de opor-se ao poder do governante.

O poder financeiro data da Idade Média e em 1215 foi inserido na Magna Carta com o princípio do "no taxation without representation" que "passa a nortear o estabelecimento do tributo, exigindo lei, norma produzida pelos representantes do povo, como instrumento de fixação do ônus fiscal". ${ }^{356}$ A ideia difundida por este princípio foi a de que, sem o consentimento dos representantes do povo, o imposto não poderia ser cobrado, posto que sua exigibilidade dependia da elaboração de lei. Fixava-se, assim, também como atribuição do Parlamento inglês, a função legislativa ${ }^{357}$.

Embora tenha sua origem voltada à cobrança dos tributos, o poder financeiro teve acrescida, ao longo dos tempos, outra dimensão: a de ser o responsável pelo controle financeiro dos atos praticados pelo governo, isto é, a atribuição de controlar o uso e a destinação do dinheiro público pelos gestores públicos, fiscalizando,

\footnotetext{
${ }^{355}$ Esta função de controle financeiro recebe, em âmbito municipal, diferentes denominações pela doutrina. Como já dissemos, José Afonso da Silva utiliza a expressão "função fiscalizadora" para se referir à fiscalização financeira e orçamentária que a Câmara Municipal desempenha com o auxílio do Tribunal de Contas no exercício do controle externo. Também são exemplos de função fiscalizadora, para este autor, o pedido de informações ao Prefeito, as comissões parlamentares de inquérito e o julgamento das contas do Prefeito. SILVA, José Afonso da. Curso... Op. cit. pp. 646-647. Hely Lopes Meirelles, por sua vez, prefere a expressão "função de controle e fiscalização", na qual insere somente a fiscalização contábil, financeira, orçamentária, operacional e patrimonial a cargo da Câmara Municipal no exercício do controle políticoadministrativo, que engloba o julgamento das contas do Prefeito e das infrações político-administrativas por ele praticadas e que levam à cassação do seu mandato. MEIRELLES, Hely Lopes. Direito municipal... Op. cit. pp. 458-460. Preferimos a expressão "função de controle financeiro" para manter consonância com o nosso trabalho, que versa sobre o controle das contas municipais, porque o controle financeiro se insere na função típica do poder financeiro, tal como retratado neste Capítulo e no primeiro.

${ }^{356}$ CAGGIANO, Monica Herman Salem. Direito... Op. cit. p. 21.

${ }^{357}$ A competência para elaborar a lei foi uma conquista somente do século XV, quando, no ano de 1462 "passa o parlamento britânico a contar com a possibilidade de apresentar, diretamente, por seus membros, as 'Bills' (leis), as quais, à medida que houvesse acordo entre as duas casas, deveriam ser aprovadas pelo Rei. A partir desse momento, a ele restava, tão-só, promulgar o texto". CAGGIANO, Monica Herman Sallem. Direito... Op. cit. p. 12. No mesmo sentido, Manoel Gonçalves Ferreira Filho explica que "o poder de votar as regras jurídicas - as leis - foi, em realidade, conquistado por essas Câmaras, na Inglaterra, a 'mãe dos Parlamentos', por meio de uma barganha: o consentimento em impostos em troca da extensão de sua influência na função legislativa. Em razão desse poder financeiro, conta o Legislativo com um auxiliar, o Tribunal de Contas" (grifos nossos). FERREIRA FILHO, Manoel Gonçalves. Curso... Op. cit. p. 160.
} 
para tanto, a matéria orçamentária. Sobre estas tarefas, que assumem uma "conotação bifacial”, profere Monica Herman Salem Caggiano:

\begin{abstract}
"Assim, se de um lado indica a competência privativa do Poder Legislativo de estabelecer os tributos, de outro envolve a incumbência que lhe é conferida de proceder ao controle financeiro atinente à atuação governamental, assegurando-lhe a possibilidade de manter vigilância e fiscalizar 'pari passu' a execução do orçamento, em toda sua extensão, sendo este previamente aprovado pelo próprio Parlamento". ${ }^{358}$ (grifos nossos)
\end{abstract}

Neste passo, fazemos um parênteses, para mencionar alguns exemplos da atuação da Câmara dos Vereadores na matéria relativa ao controle financeiro: a necessidade de uma lei - lei orçamentária municipal - aprovar o orçamento do Município; a existência de uma Comissão mista permanente, a "Comissão do Orçamento" ${ }^{359}$, formada por vereadores, para avaliar a matéria orçamentária; e a possibilidade de os vereadores poderem aprovar ou rejeitar recursos que comporão as receitas a serem utilizadas pelo Prefeito no exercício seguinte, o que influenciará a adoção ou não de políticas públicas pelo Poder Executivo ${ }^{360}$.

Também se enquadra nas funções de controle da Câmara Municipal o julgamento das contas do Prefeito, mas esta constitui função de controle político, que analisaremos no tópico seguinte.

Estas são algumas das formas pelas quais o Poder Legislativo municipal exerce o controle sobre o uso que o Prefeito deu ao dinheiro público.

Voltemos, agora, à evolução do controle financeiro ao longo da história. Com o passar do tempo, na Idade Contemporânea, o controle financeiro assume conotação “investigatória”. Sobre ela, destaca Monica Herman Salem Caggiano:

"No mundo contemporâneo, contudo, a ênfase do poder financeiro dos Parlamentos incide, na realidade, sobre a sua vertente investigatória -

\footnotetext{
${ }^{358}$ CAGGIANO, Monica Herman Salem. Direito... Op. cit. p. 21.

${ }^{359} \mathrm{O}$ embasamento constitucional da existência desta Comissão mista permanente é o artigo 166, caput e $\S$ $1^{\circ}$. É que, por se tratar de um Estado federal e, obedecendo-se ao princípio da simetria, bem como ao fato de os entes federativos serem autônomos, com as suas próprias capacidades organizativas, os Estados-membros, Distrito Federal e municípios também têm suas próprias Comissões.

${ }^{360}$ CAGGiAnO, Monica Herman Salem. Direito... Op. cit. p. 22. A autora dá os exemplos considerados no âmbito federal. Coube a nós a adequação à esfera municipal.
} 
o seu papel de verdadeiro vigilante -, tarefa que o Legislativo desempenha com o auxílio de sistemas técnicos, desenvolvidos com o escopo de lhe assegurar mecanismos a melhor acompanhar todo o processo de execução orçamentária, viabilizando a adequada análise das receitas e das despesas, do ponto de vista da legalidade e da finalidade perseguida". ${ }^{361}$ (grifos nossos)

Dentre tais "sistemas técnicos" de controle financeiro encontramos as "Entidades de Fiscalização Superior" (EFS) ou "Instituições Supremas de Controle" (ISC) que, como visto no Capítulo III assumem a forma, no Brasil, de Tribunais de Contas, órgãos de auxílio do Poder Legislativo para realizar o controle externo.

A tarefa do Tribunal de Contas concerne ao controle financeiro da matéria orçamentária no seu aspecto técnico, destacando-se, neste campo, a apreciação das contas anualmente prestadas pelo Chefe do Poder Executivo e o julgamento das contas dos administradores e dos demais responsáveis por dinheiro público, consoante incisos I e II do artigo 71 da Constituição Federal, cujas diferenças, serão melhor estudadas no item 4.4.4 (As competências constitucionais e os tipos de contas) sobre o Tribunal de Contas.

A respeito desta função de controle financeiro (ou de fiscalização), impende destacar que ela ganha, em cenário pátrio e no âmbito municipal, a mesma importância que é conferida à tarefa legislativa, tanto que foram inseridas - legislação e fiscalização - no mesmo inciso, uma ao lado da outra. Com efeito, dispõe o artigo 29, XI, da Constituição Federal que:

“Art. 29. O Município reger-se-á por lei orgânica (...) atendidos os princípios estabelecidos nesta Constituição, na Constituição do respectivo Estado e os seguintes preceitos:

XI - organização das funções legislativas e fiscalizadoras da Câmara Municipal". ${ }^{362}$ (grifos nossos)

Estas funções são, ainda, nas palavras de Hely Lopes Meirelles, "preceitos obrigatórios a serem observados na elaboração das leis orgânicas municipais". ${ }^{363}$ Significa, então, que em âmbito municipal, a Câmara Municipal deverá

\footnotetext{
${ }^{361}$ Idem. p. 23.

362 BRASIL. Constituição (1988). Constituição da República Federativa do Brasil: promulgada em 5 de outubro de 1988: atualizada até a Emenda Constitucional nº 67, de 22-12-2010. 45a ed. ampl. São Paulo: Saraiva, 2011. p. 34 e p. 37.

363 MEIRELLES, Hely Lopes. Direito municipal... Op. cit. p. 458. O Município de São Paulo dedicou a Seção VII - "Da Fiscalização Contábil, Financeira e Orçamentária" do Capítulo I - "Do Poder Legislativo" -
} 
desempenhar, com vigor, tanto a elaboração das leis como a tarefa de controle, com ênfase, no nosso caso, para a função de controle financeiro das contas municipais.

\section{Mais. A Constituição de 1988 cuida da função de controle} financeiro ainda no artigo 31, ao estabelecer que a fiscalização do Município será exercida pela Câmara Municipal na realização do controle externo ${ }^{364}$ e pelos controles internos de cada Poder.

Não poderia ter sido outra a conotação dada pela Constituição Federal de 1988 porque, como se disse nos itens 1.4.2 (O Poder Executivo) e 4.3.1 (A preponderância da função de controle), a função legislativa estava em decadência devido ao forte desenvolvimento do Welfare State e à necessidade do Chefe do Poder Executivo assumir as rédeas para o crescimento do país. É com a função de controle, especialmente a relacionada à fiscalização dos gastos públicos e à utilização das verbas públicas pelo Poder Executivo, que o Poder Legislativo, na década de noventa, ganha novamente espaço no cenário mundial. Sobre o tema, assevera Monica Herman Salem Caggiano:

"E, nesse novo quadro, marcado pelo notável desenvolvimento das
funções normativas do Poder Executivo, resta acentuado aos
Parlamentares o poder de controle - a função fiscalizadora, competência
que, entre nós, foi expressamente conferida ao Congresso, até de forma

do Título III - "Da Organização dos Poderes" da Lei Orgânica do Município para tratar, nos seus artigos 47 a 53, de como se processa a função de controle financeiro (ou função fiscalizadora) da Câmara Municipal, que conta com o auxílio do Tribunal de Contas do Município. Verifica-se que os artigos desta seção, graças ao princípio da simetria constitucional, são praticamente cópia do disposto nos artigos 70 a 75 da Constituição Federal, adequados à realidade municipal. Não poderia ser diferente, também em razão do que determina o artigo 75 da Constituição Federal: “as normas estabelecidas nesta seção aplicam-se, no que couber, à organização, composição e fiscalização dos Tribunais de Contas dos Estados e do Distrito Federal, bem como dos Tribunais e Conselhos de Contas dos Municípios”. BRASIL. Constituição (1988). Constituição da República Federativa do Brasil: promulgada em 5 de outubro de 1988: atualizada até a Emenda Constitucional no 67, de 22-12-2010. 45ª ed. ampl. São Paulo: Saraiva, 2011. p. 72.

${ }^{364}$ Giovani da Silva Corralo explica o controle externo: "É possível afirmar que a Câmara Municipal efetiva tanto um trabalho de fiscalização como de controle da Administração local, conforme as disposições dos arts. 29, XI, e 31 da CF, que definem a competência da lei orgânica municipal para disciplinar a organização das funções legislativas e fiscalizadoras da Câmara. Evidentemente, tais funções devem ser pormenorizadas na legislação ordinária municipal. Essa atuação fiscalizadora e de controle é denominada de controle externo, pois traduz a fiscalização e o controle de um Poder por outro - no caso, do Executivo pelo Legislativo, que ocorre com o auxílio do Tribunal de Contas do Estado". CORRALO, Giovani da Silva. O Poder Legislativo municipal: aportes teóricos e práticos para a compreensão e o exercício da função parlamentar nas Câmaras de Vereadores. São Paulo: Malheiros, 2008. p. 37. É preciso esclarecer, contudo, que o controle externo de que trata o autor é realizado com o auxílio do Tribunal de Contas do Estado ou do Conselho ou Tribunal de Contas dos Municípios ou, ainda, em se tratando dos Municípios de São Paulo e do Rio de Janeiro, com o auxílio do Tribunal de Contas do Município destas duas cidades, tudo isso consoante o $\S 1^{\circ}$ do artigo 31 da Constituição Federal. 
robustecida no âmbito da nova Constituição de $1988^{\prime 3}{ }^{365}$ (grifos da autora)

Outra não poderia ter sido, portanto, a importância que a Constituição Federal de 1988, seguindo os passos de outras Constituições modernas, conferiu à função de controle financeiro no ordenamento pátrio, inserindo-a lado a lado com a função legislativa, pelo menos em seara municipal.

A Constituição Federal de 1988 estabelece, ainda, que o controle externo processar-se-á por meio da fiscalização contábil, financeira, orçamentária, operacional e patrimonial, que é realizada pela Câmara Municipal com o auxílio dos Tribunais de Contas dos Estados ou do Conselho (ou Tribunal) de Contas dos Municípios e, nos casos dos Municípios de São Paulo e do Rio de Janeiro, diferentemente do que ocorre em todos os demais Municípios brasileiros, dos Tribunal de Contas do Município de São Paulo e do Município do Rio de Janeiro.

Assevera-se, ademais, que esta função não é apenas de legalidade, mas também de economicidade e de legitimidade, o que representou uma conquista no alargamento da função de controle financeiro. Monica Herman Salem Caggiano também se manifestou sobre este alargamento. Consoante a autora:

\footnotetext{
"Em verdade notória é a importância do controle exercido por essa Corte, na medida em que a ela compete a fiscalização pari passu de todo ato de despesas e, examinando sua legalidade e sua essência, verificar se, o mesmo, consulta o interesse público. Longe, pois de se ater à mera análise formalística da adequação da despesa e da receita ao programa orçamentário, passa o Tribunal a promover um verdadeiro acompanhamento da execução financeira e orçamentária - sem sombra de dúvida, à luz das normas em vigor - mas transpondo, não raras vezes, até mesmo as fronteiras do núcleo referente ao mérito do ato administrativo, até há bem pouco tempo vedado ao exame dos outros poderes instituídos". ${ }^{366}$ (grifos nossos)
}

Com efeito. Por meio do controle financeiro analisa-se não somente a observância à legalidade, mas, também, o seu mérito. Forçoso convir, entretanto, que a parte que se sentir prejudicada com uma decisão do Tribunal de Contas

\footnotetext{
365 CAGGIANO, Monica Herman Salem. Controle parlamentar da administração. Revista de Direito Público. Ano 24, n. 96. São Paulo: Revista dos Tribunais, out/dez., 1990. p. 150.

${ }^{366}$ Idem. pp. 150-151.
} 
pode socorrer-se do Poder Judiciário ${ }^{367}$ para tentar reverter a situação, consoante assegura o Texto Constitubional brasileiro.

Releva destacar, por fim, que, graças ao disposto no $\S 3^{\text {o368 }}$ do artigo 31 da Constituição Federal, que confere a qualquer contribuinte o direito de acesso às contas do Município para, se quiser, questionar a sua legitimidade, a função de controle financeiro pode, hoje, ser desenvolvida também pelo contribuinte e não apenas pela Câmara Municipal com o auxílio do Tribunal de Contas. É este o entendimento de Hely Lopes Meirelles, que explana:

\begin{abstract}
"Podemos sustentar, em face dos meios constitucionais postos à disposição dos administrados e notadamente do disposto no art. $31, \S 3^{\circ}$, da $\mathrm{CF}$, que a fiscalização da conduta dos governantes, que antes era um privilégio do Poder Legislativo, na atualidade se estendeu ao próprio cidadão, e em especial ao contribuinte, que hoje em dia tem um direito subjetivo ao governo honesto. A moralidade pública e a probidade administrativa dos agentes do poder são um direito do povo, daí a razão por que o controle da legalidade da Administração foi ampliado até o mais simples cidadão (CF, art. $5^{\circ}$, LXXIII). Mas nem por isso descabe à Câmara fiscalizar, controlar e reprimir os atos do Executivo, na medida e pela forma que a Constituição da República e a lei orgânica do Município lhe asseguram. Tratando-se de um controle político, só alcança os agentes políticos, e não os servidores, sujeitos ao controle hierárquico do Executivo". ${ }^{369}$ (grifos nossos)
\end{abstract}

Também sobre o "direito subjetivo ao governo honesto" assevera Erik Boson: "sob o prisma constitucional, portanto, a moralidade administrativa não foi assegurada apenas como um mero princípio da administração pública, mas essencialmente

\footnotetext{
${ }^{367}$ Daí porque Monica Herman Salem Caggiano assevera que a decisão do Tribunal de Contas não faz coisa julgada. Nas palavras da autora: "Releva advertir, contudo, que nos moldes da nossa sistemática jurisdicional inafastável resta a competência revisional do Poder Judiciário, não podendo ser atribuída, às decisões emanadas das Cortes de Contas, a qualidade de coisa julgada". Idem. p. 151. Concordamos com a autora. O inciso XXXV do artigo $5^{\circ}$ da Constituição Federal prega o princípio da inafastabilidade do Poder Judiciário. Significa, então, que a parte que se sentir lesada por uma decisão do Tribunal de Contas pode tentar a reversão do resultado no Poder Judiciário com a ressalva, pensamos, de que este deve se ater à análise da ocorrência de ilegalidade ou inconstitucionalidade praticada pela Corte de Contas.

368 “Art. 31. (...) § $3^{\circ}$. As contas dos Municípios ficarão, durante 60 (sessenta) dias, anualmente, à disposição de qualquer contribuinte, para exame e apreciação, o qual poderá questionar-lhes a legitimidade, nos termos da lei”. BRASIL. Constituição (1988). Constituição da República Federativa do Brasil: promulgada em 5 de outubro de 1988: atualizada até a Emenda Constitucional no 67, de 22-12-2010. 45 ed. ampl. São Paulo: Saraiva, 2011. p. 40.

${ }^{369}$ MEIRELLES, Hely Lopes. Direito municipal... Op. cit. p. 460.
} 
como um direito público subjetivo de qualquer cidadão, e, como tal, exigível administrativa e judicialmente", 370

Este "direito público subjetivo ao governo honesto" constitui, pois, mais uma forma de controle, agora nas mãos do povo, para fiscalizar como o dinheiro público foi gasto. Aplica-se, como já expusemos, a lição de Karl Loewenstein, de colocar o eleitorado $^{371}$ como o "detentor supremo" 372 do poder, controlando, ao final, como os recursos públicos foram gastos pelo Prefeito e como a Câmara dos Vereadores procedeu à fiscalização sobre tais gastos.

Entendida a função de controle financeiro da Câmara Municipal, que se desenvolve com o auxílio do Tribunal de Contas, passamos, em seguida, à função de controle político.

\subsubsection{A função de controle político ${ }^{373}$}

Se, por um lado, foi a função legislativa que, nos séculos XVIII e XIX, logo após a instituição do Estado de Direito, transformou o Poder Legislativo no centro das atenções no cenário político, de modo que as demais funções estatais giravam em torno da produção legislativa, por outro, foi a função de controle político que o fez

\footnotetext{
${ }^{370} \mathrm{BOSON}$, Erik. O direito fundamental ao governante probo, a análise da vida pregressa do candidato e a presunção de inocência/não culpa: uma análise à luz da Lei da "Ficha Limpa". Revista da Procuradoria Geral do Estado de São Paulo. n. 72. São Paulo: jul./dez., 2010. p. 124.

${ }^{371}$ Karl Loewenstein defende que o eleitorado é um detentor do poder. No caso específico desta citação, pode ser inserido no conceito de detentores do poder também o povo e isto porque mesmo quem não vota tem o direito de controlar os gastos públicos, já que na República quem utiliza o dinheiro público é mero intermediário dos efetivos donos do dinheiro público: o povo.

${ }^{372}$ Já utilizamos a citação que se segue no Capítulo III, item 3.3.1.5 (O controle popular (ou o controle social)) entretanto, devido à pertinência do tema, tomamos a liberdade de repeti-la: "O eleitorado adquire, assim, a categoria de detentor supremo do poder exercendo um controle final sobre o Governo e o Parlamento". LOEWENSTEIN, Karl. Op. cit. p. 326.

${ }^{373}$ Odete Medauar, em âmbito nacional e cenário administrativo, analisa qual a expressão mais correta para se referir ao controle realizado pelo Poder Legislativo: controle político, legislativo ou parlamentar. Descarta o primeiro, porque outros órgãos de controle também podem exercê-lo. Rejeita o segundo, pois "controle legislativo" poderia dar a ideia de que é um controle realizado pela lei, o que não é o caso. Prefere, então, a expressão "controle parlamentar" ou "controle do Poder Legislativo", que "revela de imediato, a referência à fiscalização exercida pelo Parlamento ou Poder Legislativo". MEDAUAR, Odete. Controle da administração pública. São Paulo: Revista dos Tribunais, 1993. p. 88. Preferimos, contudo, a expressão "controle político" porque se trata de uma das funções típicas do Poder Legislativo e porque uma de nossas intenções, na tese, é verificar se o Tribunal de Contas também exerce controle político quando elabora o parecer prévio sobre as contas do Prefeito.
} 
ressurgir, já no final do século XX, logo após um período de intensa preponderância do Poder Executivo, conferindo-lhe, novamente, importância ${ }^{374}$ neste mesmo quadro.

Esta função, desenvolvida com o sistema de controles recíprocos (dos freios e contrapesos) de um Poder sobre o outro, atribui ao Poder Legislativo o papel de "fiscal" dos atos praticados pelo Poder Executivo. Sobre ela, assevera Monica Herman Salem Caggiano:

“(...) desponta munida de instrumentos, senão modernos e novidadeiros, ao menos de qualificada eficiência para a fiscalização das políticas públicas adotadas pelos governos e sua aplicação. Ingressa-se, pois, na esfera em que o Parlamento assume o papel de fiscal, de vigilante sobre a atividade governamental". ${ }^{375}$ (grifos nossos)

Francisco Berlín Valenzuela complementa a definição anterior, trazendo o significado da função de controle político:

"Quando se fala desta função, o significado é no sentido de inspeção, fiscalização, comprovação, revisão ou exame que faz o Parlamento sobre a atividade que realiza o Executivo, com a finalidade de verificar o ajuste de seus atos às disposições estabelecidas na lei". ${ }^{376}$ (grifos e tradução nossos)

O Poder Legislativo transforma-se em "fiscal",377, em "vigilante" dos atos governamentais. Exerce, pois, verdadeira atividade de controle - político - sobre a

\footnotetext{
374 José Levi Mello do Amaral Júnior afirma esta importância: “A Constituição de 1988 confere, com ênfase, a função de controle político ao Congresso Nacional”. AMARAL JÚNIOR, José Levi Mello do. O Poder Legislativo na democracia contemporânea: a função de controle político dos parlamentos na democracia contemporânea. Revista de Informação Legislativa. Ano 42, n. 168. Brasília: out./dez., 2005. p. 11. Disponível em: < http://www2.senado.gov.br/bdsf/item/id/905>, acesso em 15/01/2010.

${ }^{375}$ CAGGIANO, Monica Herman Salem. Direito... Op. cit. p. 30.

376 "Cuando se habla de esta función se hace referencia al significado del término en el sentido de inspección, fiscalización, comprobación, revisión o examen que lleva a cabo el parlamento sobre la actividad que realiza el ejecutivo, con la finalidad de verificar que ajusta sus actos a las disposiciones establecidas en la ley". VALENZUELA, Francisco Berlín. Op. cit. p. 139.

${ }^{377}$ O controle político confere, pois, ao Poder Legislativo a função de fiscalização, de vigilante dos atos praticados pelo Poder Executivo, nas mais diferentes matérias. Não, contudo, de todos os atos, e sim somente daqueles que a própria Constituição autoriza, sob pena de haver interferência inconstitucional de um Poder no outro. Sobre a interferência de um Poder no outro, de modo inconstitucional, assevera Helio Saul Mileski: “(...) o controle legislativo deve ocorrer tão-somente no limite da permissão constitucional, no sentido de ser preservado, no máximo possível, o princípio do equilíbrio harmônico e independente entre os Poderes. Caso o controle exceda o limite permitido, este será inconstitucional, inadmitindo-se o seu exercício". MILESKI, Helio Saul. Op. cit. p. 150.
} 
atuação do Poder Executivo. Tal função coloca ainda o Poder Legislativo, novamente, em posição de destaque no cenário político.

Há diversos exemplos ${ }^{378}$ de controle político na Lei Maior. A atividade de controle financeiro é, na verdade, um deles e o único que nos interessa detidamente neste trabalho.

\section{Consoante afirma José Levi Mello do Amaral Júnior, “a repetição} anual da discussão do orçamento é um momento importante da função de controle político". ${ }^{379}$ E complementa Maurizio Cotta: "um importante momento da função de controle, que anualmente acontece, é a discussão do orçamento. Esta tradicional atividade parlamentar confere ao Parlamento, em certos países, o poder de modificar o projeto do balanço governamental e, em outros, suas atribuições se limitam à aprovação ou à reprovação total do balanço. Há, em todo caso um relevante significado político, porque permite ao Parlamento conhecer a realidade global do programa anual do Governo e oferecer um debate geral a respeito das finalidades da ação do Executivo". ${ }^{380}$ (tradução e grifos nossos)

De fato, todas as vezes em que o Congresso se reúne para deliberar sobre a aprovação da lei orçamentária e de suas emendas, o que ocorre anualmente, está delimitando a atuação do governo quanto ao uso e destinação do dinheiro público do exercício seguinte, inclusive quanto à possibilidade de concretização ou não de políticas

\footnotetext{
${ }^{378}$ Monica Herman Salem Caggiano enumera os mecanismos de controle político à disposição do Poder Legislativo previstos na Constituição Federal de 1988: o pedido de informações a Ministros de Estado (artigo $50, \S 2^{\circ}$ ); a possibilidade de as comissões temporárias ou permanentes solicitarem depoimento das autoridades (artigo 58, $\S 2^{\circ}, \mathrm{V}$ ); as comissões parlamentares de inquérito (artigo 58, $\S 3^{\circ}$ ) e o impeachment (artigo 52, I). CAGGIANO, Monica Herman Salem. Direito... Op. cit. pp. 32-41. No mesmo sentido, José Levi Mello do Amaral Júnior enumera e explica os mecanismos de controle político presentes na Constituição: a sustação de atos normativos do Poder Executivo; a convocação de ministros e o pedido de informações; o Tribunal de Contas da União, citando os casos dos incisos VIII, IX e X, do artigo 71; as comissões parlamentares de inquérito; o orçamento e a conversão em lei de medida provisória; e o impeachment. Para maiores detalhes conferir: AMARAL JÚNIOR, José Levi Mello do. Op. cit. pp. 12-17. À evidência, em face do princípio da simetria, estes exemplos podem ser trazidos para o âmbito municipal também.

${ }^{379}$ Idem. p. 14.

380 "Un momento importante de la función de control lo da la recurrencia anual de la discusión del balance. Esta tradicional actividad parlamentaria, que en ciertos países comporta el poder del p. de modificar el proyecto de balance gubernamental mientras que en otros el rol del p. se limita a la aprobación o reprobación total, tiene en todo caso um relevante significado político porque permite ver al p. la realidad global del programa anual de gobierno y ofrece la ocasión de un debate general sobre las finalidades de la acción del ejecutivo". COTTA, Maurizio. Verbete parlamento. In: BOBBIO, Norberto; MATTEUCCI, Nicola (Coord.). Dicionário de Política L-Z. Gianfranco Pasquino (redator). Tradução de José Aricó e Jorge Tula. $2^{a}$ ed. Madrid: Siglo Veintiuno de España Editores, 1983. p. 1.179.
} 
públicas em prol da coletividade. Exerce, pois, o Poder Legislativo, efetivo controle político, como fiscal da atividade executiva na matéria orçamentária.

O controle político na matéria orçamentária não se encerra, porém, com a aprovação ou não da lei orçamentária. Encontra-se, também, no julgamento das contas do Prefeito ${ }^{381}$, cuja competência é exclusiva da Câmara dos Vereadores, em se tratando de Município. Apresenta, no entanto, uma peculiaridade: as contas do Chefe do Executivo devem ser prestadas ao órgão técnico e de auxílio do Poder Legislativo local, que é o Tribunal de Contas. Somente após a elaboração do parecer prévio sobre as contas municipais - aprovando-as ou rejeitando-as -, é que a matéria é encaminhada ao Poder Legislativo local, que irá julgá-las, mantendo ou derrubando o parecer prévio do Tribunal de Contas. Para derrubá-lo, entretanto, são necessários os votos de dois terços dos membros da Câmara dos Vereadores.

Origina-se desta atuação, prevista constitucionalmente, outro fator importante do controle político, que é a possibilidade de exigir a responsabilização política do mau gestor público. Isto ocorre porque, em um Estado Democrático de Direito, o povo é o titular da soberania e os membros do Poder Legislativo o representam, vale dizer, em última análise, que é ao povo ${ }^{382}$ que os administradores públicos estarão prestando contas, assim, aquele que tiver suas contas reprovadas pelo Poder Legislativo deve responder - por exemplo, com a inelegibilidade por oito anos - pelo mau uso do dinheiro público.

Estes são os motivos que fazem a função de controle político conferir ao Poder Legislativo tamanha relevância no panorama político.

Em cenário pátrio e, levando em consideração a atividade de controle desempenhada em âmbito administrativo, Odete Medauar faz dura crítica à eficácia e à operacionalidade da função de controle desempenhada pelo Poder

\footnotetext{
${ }^{381}$ Quanto ao julgamento das contas do Prefeito, aduz Hely Lopes Meirelles: "No nosso regime municipal, o controle político-administrativo da Câmara compreende a fiscalização contábil, financeira, orçamentária, operacional e patrimonial, através do julgamento das contas do prefeito e de suas infrações políticoadministrativas sancionadas com cassação do mandato". MEIRELLES, Hely Lopes. Direito administrativo... Op. cit. pp. 458-459.

${ }^{382}$ Sobre o controle político ser realizado em nome do povo, que é o titular da soberania, assevera Francisco Berlín Valenzuela: ${ }^{382}$ "Es un control que debe ser oportuno, de manera que el pueblo, como titular de la soberanía, pueda conocer a través del parlamento las actividades del ejecutivo y la vaoloración que éstas merecen de los representantes populares". VALENZUELA, Francisco Berlín. Op. cit. p. 140.
} 
Legislativo $^{383}$, sendo dois os motivos determinantes da descrença em relação à atuação deste Poder fiscalizador: a hegemonia que detém o Executivo no cenário político ${ }^{384}$, o que faz com que o Legislativo não tenha interesse político em contrariá-lo ${ }^{385}$ e a ausência de sanção decorrente das ações corretivas praticadas pelo Legislativo. Cuidando desta última e citando Braibant, Questiaux e Wiener, a autora assevera:

\begin{abstract}
"Nem o Congresso, nem suas comissões podem anular ou modificar atos administrativos ou condenar a administração ao pagamento de indenização ou ainda dirigir-lhe injunções; sua ação se traduz pela publicidade que dão as suas críticas e pelas consequiências legislativas e financeiras decorrentes". 386
\end{abstract}

Odete Medauar arremata defendendo que a falta de sanção realmente causa a ineficácia do mecanismo de controle político. Aduz, no entanto, que tais

\footnotetext{
${ }^{383}$ A autora diferencia o controle parlamentar do controle realizado pelo Tribunal de Contas. O pensamento da autora, de não inserir no controle parlamentar o efetivado pelo Tribunal de Contas está no livro "Direito administrativo moderno". Consoante a autora, "sob essa rubrica são considerados apenas os mecanismos de fiscalização emanados diretamente das casas legislativas, não abrangendo as instituições que extraem do Legislativo sua força para exercer controle ou que significam prolongamento desse Poder". E continua: "a função de controle sobre o Executivo aparece hoje como inerente ao Legislativo, em qualquer regime de governo do mundo ocidental". MEDAUAR, Odete. Direito administrativo brasileiro. $13^{\mathrm{a}}$ ed. rev. e atual. São Paulo: Revista dos Tribunais, 2009. p. 399. Também é possível ver a mesma ideia sendo defendida no livro "Controle da administração pública". Para detalhes, consultar: MEDAUAR, Odete. Controle da administração pública. São Paulo: Revista dos Tribunais, 1993. p. 88 e pp. 112 e ss.

${ }^{384}$ Nina Beatriz Stocco Ranieri exemplifica a hegemonia do Poder Executivo com as medidas provisórias e a inércia do Poder Legislativo em realizar o controle político. Esclarece a autora que: "Do exposto está a se evidenciar que a hipertrofia do Poder Executivo, em matéria de atuação normativa por medidas provisórias, resulta não só de uma tendência centralizadora e autoritária que se revela nas edições e reedições de Medidas Provisórias, em circunstâncias e em matérias que desbordam da outorga constitucional; como também, em igual proporção, da inércia dos demais Poderes, em relação ao controle político e constitucional, seja por omissão, seja porque o texto constitucional assim o permite". (grifos nossos) RANIERI, Nina Beatriz Stocco. Governabilidade... Op. cit. pp. 130-131. E continua: "Desta constatação seguem-se outras duas: a) que as regras democráticas, destinadas a estabelecer como se deve chegar à decisão política e como controlar o poder político estão mais voltadas a impedir o arbítrio e a garantir a liberdade individual que a assegurar a participação da maioria no governo, ressentindo-se o sistema de normas que garantam a maior participação e controle populares sobre o processo decisório; b) como a discricionariedade administrativa é ínsita às regras democráticas, o fortalecimento do Poder Executivo e a legitimação de suas ações advêm dos resultados alcançados, e não da estrutura jurídico-formal". Idem. Ibidem.

${ }^{385}$ Sobre a hegemonia do Executivo e a descrença na função de controle do Legislativo, Odete Medauar explana que: “(...) embora o ordenamento discipline atuações de controle do Legislativo sobre o Executivo, inexiste interesse político na realização concreta e eficaz da vigilância, para não desagradar ao detentor do Poder Executivo. A nosso ver, a deterioração da atividade legislativa, a submissão cega ao Executivo propiciam a inoperância da função de controle, em vez de acentuá-la". (grifos nossos). MEDAUAR, Odete. Controle da administração pública. São Paulo: Revista dos Tribunais, 1993. pp. 90-91.

386 BRAIBANT, Guy; WIENER, Celine; QUESTIAUX, Nicole. Le contrôle de l'administration et la protection des citoyens. Paris: Cujas, 1973. p. 305. Apud MEDAUAR, Odete. Controle da administração pública. São Paulo: Revista dos Tribunais, 1993. p. 91.
} 
sanções, se existissem, "acarretariam conseqüências indesejáveis às autoridades administrativas, mesmo desprovidas da aptidão para desfazer atos ou medidas". 387

As lições da autora precitada nos fazem indagar: qual é, afinal, o papel do Poder Legislativo na função de controle? Se ele não tem interesse político em proceder à fiscalização - efetiva - sobre o Poder Executivo, dada a hegemonia deste último, qual a finalidade do controle legislativo? Estaria havendo, então, desvirtuamento da separação de Poderes, na medida em que o controle político, se realizado, permite o equilíbrio entre estes? Em caso positivo, a "culpa" seria do próprio Legislativo? Por outro lado, deveriam existir sanções aplicadas ao Legislativo se ele não cumprisse a sua função constitucional de controle político? Que tipos? Como seriam aplicadas, considerando que não se admite que um Poder interfira no outro sem expressa previsão constitucional?

Transpondo a questão agora para o âmbito específico de nossa tese: é possível exigir da Câmara dos Vereadores o julgamento das contas municipais ${ }^{388}$ ? Se o Poder Legislativo não julgá-las, não estará subtraindo do povo o seu direito constitucional de avaliar a prestação de contas do uso dos recursos públicos pelo governante e a possibilidade de este ser responsabilizado por eventual má versação do dinheiro?

Estas perguntas são de difícil resposta e, neste momento, não trataremos da matéria, relativa especificamente à tese.

A princípio, pensamos que o papel do Legislativo é controlar, de fato, o Executivo. É esta a essência do controle político: delimitar, vigiar, verificar, monitorar de forma contínua as ações do "ator principal", que é o Poder Executivo. Não

\footnotetext{
${ }^{387}$ MEDAUAR, Odete. Controle da administração pública. São Paulo: Revista dos Tribunais, 1993. p. 91. Continua a autora: “Assim, por exemplo, no caso de necessidade de aprovação ou autorização do Legislativo para certos atos; no caso da atuação das comissões de inquérito, cujo relatório deveria receber ampla divulgação e ser objeto de manifestação do plenário". MEDAUAR, Odete. Controle da administração pública. São Paulo: Revista dos Tribunais, 1993. p. 91.

388 Consoante disposição constitucional e observado o princípio da simetria, o Prefeito tem sessenta dias, após aberta a sessão legislativa, para encaminhar as contas do exercício anterior à Câmara dos Vereadores (artigo 84, XXIV) e o Tribunal de Contas possui sessenta dias para apreciá-las (artigo 71, I). No Município de São Paulo, no entanto, o prazo do Tribunal de Contas sobe para noventa dias, isto em razão do disposto no inciso I do artigo 48 da Lei Orgânica. Ressalte-se, ainda, que, embora a Constituição Federal disponha que o Prefeito tem a competência de "prestar, anualmente, à Câmara dos Vereadores" as suas contas (artigo 84, XXIV), elas não são de imediato julgadas por tal Poder. Na prática, o Prefeito, pessoalmente ou por meio de um de seus secretários, as entrega ao Tribunal de Contas, que as apreciará por meio de parecer prévio apresentado em Plenário. Somente depois é que este será enviado à Câmara Municipal para julgamento. Ademais, enquanto Prefeito e Tribunal de Contas têm prazo de sessenta dias para exercerem suas funções, o mesmo não se observa para o Poder Legislativo, que deverá julgar as contas, não havendo, no entanto, fixação de prazo para tal
} 
cabe ao Legislativo furtar-se ao cumprimento da Constituição. E, se o faz, não está desempenhando a sua função de controle com eficiência. A situação se agrava na medida em que este Poder é composto por representantes do povo, que deseja o controle político ou que, pelo menos, tem direito constitucional ao controle. Ao não exercer o controle efetivamente - no caso específico, ao não julgar as contas municipais - o vínculo de confiaça entre detentor e destinatário do Poder se rompe e isso não é bom para a democracia.

Tal situação provoca, sim, o desvirtuamento da separação de Poderes e estimula ainda mais o Poder Judiciário a exercer a função de controle político, o chamado ativismo judicial. Não é sem razão que a Ministra Ellen Gracie Northfleet, às vésperas de se aposentar do Supremo Tribunal Federal, em entrevista à Revista Veja, analisando se a Corte mudou muito nestes quase onze anos em que ela lá atuou, respondeu:

\begin{abstract}
"Creio que a corte de dez anos atrás era mais contida, mais dada ao 'judicial restraint', uma expressão em inglês que indica um esforço para não se substituir ao legislador. Acontece que a demanda para que o STF resolvesse impasses políticos também era menor. Hoje, há temas controversos que o Congresso não aborda. Os parlamentares não querem se comprometer com uma posição. As demandas, então, vão parar no Supremo, que não tem outra saída senão decidir sobre tais assuntos." ${ }^{389}$ (grifos nossos)
\end{abstract}

Lembramos, no entanto, que legislar não é função do Supremo Tribunal Federal. Se o faz, é porque o Legislativo é omisso e esta inércia dá causa ao ativismo judicial e, pois, ao crescimento da função de controle desempenhada pelo Poder Judiciário.

Quanto às sanções ao Poder Legislativo, no exercício da função de controle político, concordamos com Odete Medauar, no sentido de que a sua ausência interfere na eficácia da atividade. Visando a contornar tal problemática, aduz a autora que Jean Waline, levando em consideração o governo francês, sugere que um "controle

\footnotetext{
${ }^{389}$ Entrevista Ellen Gracie Northfleet. Revista Veja. Edição 2232. São Paulo: Abril, 31 de agosto, 2011. p. 19. A Ministra continua: "Eu não diria que existe no STF uma atitude concertada para adotar o ativismo judicial. Alguns ministros - muito bem amparados na doutrina e na técnica - avançam mais nessa direção. Outros, menos. Não vejo, contudo, um interesse em aumentar o poder do Supremo. Nosso poder já é bem grande. O certo é que nesses últimos dez anos foram as circunstâncias que fizeram do dilema entre ativismo e contenção um aspecto central para a corte". Entrevista Ellen Gracie Northfleet. Revista Veja. Edição 2232. São Paulo: Abril, 31 de agosto, 2011. p. 22.
} 
parlamentar eficaz deveria prever a responsabilidade individual dos ministros por iniciativa da Assembléia Nacional ou do Parlamento". 390

Em que pese nosso país não adotar o sistema parlamentarista, indagamos se um controle como o sugerido por Jean Waline seria cabível no Brasil presidencialista, no que concerne às contas municipais. Isto é, seria possível responsabilizar os parlamentares, individualmente, no caso de não julgamento das contas municipais? Esta pergunta será abordada novamente nas Conclusões deste trabalho.

Insta salientar, por importante, que a função de controle político é essencial para a democracia, na medida em que permite ao povo soberano exercer a função de controlador dos atos públicos. Por este motivo, a tarefa de vigilância, de fiscalização deveria ser desempenhada com vigor pelo Poder Legislativo, não lhe sendo atribuída a possibilidade de abrir mão do "interesse político" em agir. ${ }^{391}$

Feitas estas observações necessárias, partimos, agora, para as características do controle político.

Hely Lopes Meirelles ensina que o controle político é o realizado pelo Poder Legislativo (Congresso Nacional, Assembleias Legislativas e Câmaras Municipais) ou pelas comissões parlamentares de inquérito sobre alguns atos dos Poderes Executivos federal, estaduais e municipais. Assevera, ainda, tratar-se de controle eminentemente político e, como tal, pautado na legalidade, mas, também, na conveniência e oportunidade, objetivando os fins maiores da nação, sem se voltar, por isso, aos direitos individuais dos administrados. ${ }^{392}$

Aduz, ainda, o Professor, que algumas atribuições administrativas do Poder Executivo devem ser desempenhadas em cooperação com o Poder Legislativo,

\footnotetext{
${ }^{390}$ WALINE, Jean. L'evolution du contrôle de l'administration depuis un siècle. Revue du Droit Public et de la Science Politique. set-out., 1984. p. 1349. Apud MEDAUAR, Odete. Controle da administração pública. São Paulo: Revista dos Tribunais, 1993. p. 110.

${ }^{391}$ Forçoso convir, entretanto, que este controle legislativo é tipicamente desenvolvido pela oposição e sobre ela profere Edna Delmondes: "tem-se como senso comum que a atividade de controlar é típica da oposição, que se compõe de minorias; esses são os únicos agentes com interesses específicos na atividade fiscalizatória, posto que a maioria, porquanto situação, prescinde que se lhe averigue a atuação governamental". DELMONDES, Edna. A interação do Tribunal de Contas com o parlamento. Rio de Janeiro: Renovar, 2007. p. 17. Isto quer dizer que, se o Executivo contar com a maioria no Congresso, dificilmente o Poder Legislativo terá, de fato, "interesse político" em agir na atividade de controle. Por outro lado, se o Executivo possuir apenas a minoria no Congresso, a atividade de controle - realizada pela maioria - será intensa e concernente ao controle da atuação governamental. Daí decorre, portanto, a dificuldade em se estabelecer sanções ao não cumprimento, pelo Legislativo, de sua função de controle parlamentar.

392 MEIRELLES, Hely Lopes. Direito administrativo... Op. cit. p. 695.
} 
porque dizem respeito a assuntos de "extensas repercussões políticas internas ou externas, que só o Parlamento está em condições de bem valorar e decidir sobre sua legitimidade e conveniência" ${ }^{\prime 393}$ e, em outros casos, o controle político é necessário para manter o equilíbrio entre os Poderes, como na hipótese da aprovação do orçamento ou da fiscalização de sua execução. ${ }^{394}$

Maria Sylvia Zanella Di Pietro explica que o controle político pode ser de legalidade ou de mérito e que é esta última característica que qualifica o controle como de natureza política, pois "vai apreciar as decisões administrativas sob o aspecto inclusive da discricionariedade, ou seja, da oportunidade e conveniência diante do interesse público". 395

Como exemplos do controle político encontram-se a possibilidade de o Poder Legislativo "fiscalizar e controlar, diretamente, ou por qualquer de suas Casas, os atos do Poder Executivo, incluídos os da administração indireta", na exegese do inciso $\mathrm{X}$ do artigo 49 da Constituição Federal, bem como a de processar e julgar o Presidente da República e o seu Vice nos crimes de responsabilidade (artigo 52, I), o julgamento das contas do Presidente da República (e também dos Governadores e dos Prefeitos) (artigo 49 , IX) e as comissões parlamentares de inquérito (artigo 58, § $3^{\circ}$ ). Todos estes exemplos também se aplicam ao âmbito municipal em razão da autonomia dos entes federativos e por conta do princípio da simetria constitucional.

Vista a forma pela qual o controle político atua, analisaremos, no tópico seguinte, a participação do Tribunal de Contas na função de controle das contas municipais.

\subsection{Do Tribunal de Contas em âmbito municipal}

Passamos, agora, à análise da participação do Tribunal de Contas na função de controle externo dos gastos públicos efetuados pelo Chefe do Poder Executivo local.

\footnotetext{
${ }^{393}$ Idem. pp. 695-696. Citamos, como exemplo, a assinatura de um tratado internacional, que é realizada pelo Presidente da República, mas que depende, para sua validade no ordenamento interno, da ratificação do Congresso Nacional e a autorização prévia do Congresso Nacional para que o Presidente da República decrete o estado de sítio.

${ }^{394}$ Idem. p. 696.

395 DI PIETRO, Maria Sylvia Zanella. Direito... Op. cit. p. 704.
} 
Ressaltamos, de início, como já foi abordado em outros capítulos, que o controle que o Tribunal de Contas exerce é técnico e que a fiscalização contábil, financeira, orçamentária, operacional e patrimonial das contas públicas, a cargo do Poder Legislativo, é desempenhada com o auxílio do Tribunal de Contas que possui, também, competências próprias elencadas nos incisos I a XI do artigo 71 da Constituição Federal. Daí sua importância no cenário pátrio.

Vejamos, inicialmente, o tratamento constitucional do Tribunal de Contas no âmbito municipal.

\subsubsection{O tratamento constitucional do Tribunal de Contas no âmbito do Município: os Tribunais de Contas dos Estados; os Tribunais (ou Conselhos) de Contas dos Municípios e os Tribunais de Contas dos Municípios de São Paulo e do Rio de Janeiro}

Inicialmente compete-nos esclarecer a respeito da apreciação, pelo Tribunal de Contas, das contas dos Prefeitos em território nacional. Assim é que, no âmbito municipal, podem exercer essa função: o Tribunal de Contas do Estado, o Tribunal ou Conselho de Contas dos Municípios ou o Tribunal de Contas do Município. A determinação está expressa no $\S 1^{\circ}$ do artigo 31 da Constituição Federal, que dispõe: “o controle externo da Câmara Municipal será exercido com o auxílio do Tribunal de Contas dos Estados ou do Município ou dos Conselhos ou Tribunais de Contas dos Municípios, onde houver ${ }^{, 396 .}$.

Isto significa que, sob a égide da Constituição de 1988, o controle das contas do Prefeito, pelo Tribunal de Contas, faz-se das seguintes formas: a) nos casos dos Municípios de São Paulo e do Rio de Janeiro, a apreciação das contas anuais do Executivo municipal é feita pelo Tribunal de Contas do Município, órgão municipal, que tem competência para a apreciação apenas das contas dos Prefeitos destes dois municípios; b) pelos Tribunais de Contas dos Municípios (ou Conselhos dos Municípios), órgãos estaduais, que examinam as contas dos Prefeitos dos Estados da Bahia, do Ceará, de Goiás e do Pará. Nestes casos, o Tribunal de Contas dos Municípios integra a estrutura

\footnotetext{
${ }^{396}$ BRASIL. Constituição (1988). Constituição da República Federativa do Brasil: promulgada em 5 de outubro de 1988: atualizada até a Emenda Constitucional no 67, de 22-12-2010. 45 a ed. ampl. São Paulo: Saraiva, 2011. p. 39.
} 
organizacional do Estado-membro, sendo que a fiscalização contábil-orçamentária municipal é conferida ao Tribunal ou ao Conselho de Contas dos Municípios; c) pelo Tribunal de Contas Estadual, que aprecia as contas dos Prefeitos dos municípios que não se enquadram nas hipóteses citadas nas alíneas anteriores.

Depreende-se, daí, que a análise das contas em âmbito municipal envolve, em todos os casos, exceto nos Municípios de São Paulo e do Rio de Janeiro, um Tribunal de Contas de âmbito estadual, que aprecia as contas dos Prefeitos. Em todas as hipóteses, porém, o julgamento das contas do Prefeito é competência da Câmara Municipal, em decorrência do que dispõe o $\S 2^{\circ}$ do artigo 31 da Constituição Federal: "O parecer prévio, emitido pelo órgão competente sobre as contas que o Prefeito deve anualmente prestar, só deixará de prevalecer por decisão de dois terços dos membros da Câmara Municipal", 397 (grifos nossos)

\subsubsection{A vedação constitucional para a criação de novos Tribunais, Conselhos ou órgãos de Contas Municipais}

A Constituição Federal de 1988 veda, ademais, a criação de novos Tribunais, Conselhos ou órgãos de Contas Municipais, nos exatos termos do artigo 31, § $4^{\text {o398 }}$.

A vedação é taxativa. Assim, nem mesmo os Municípios Capitais dos Estados-membros, à exceção de São Paulo e Rio de Janeiro, constitucionalmente mantidos, podem ter os seus próprios Tribunais de Contas.

Discorrendo sobre o tema, Manoel Gonçalves Ferreira Filho assevera que a criação de novos Tribunais de Contas em âmbito municipal foi tratada com "hostilidade" "399, já pela Emenda no 1/69, cujo artigo 191 dispunha: "Continuará em funcionamento apenas o Tribunal de Contas do Município de São Paulo, salvo deliberação em contrário da respectiva Câmara, sendo declarados extintos todos os outros tribunais de

\footnotetext{
397 BRASIL. Constituição (1988). Constituição da República Federativa do Brasil: promulgada em 5 de outubro de 1988: atualizada até a Emenda Constitucional n ${ }^{\circ}$ 67, de 22-12-2010. $45^{\mathrm{a}}$ ed. ampl. São Paulo: Saraiva, 2011. p. 40.

398 BRASIL. Constituição (1988). Constituição da República Federativa do Brasil: promulgada em 5 de outubro de 1988: atualizada até a Emenda Constitucional no 67, de 22-12-2010. 45a ed. ampl. São Paulo: Saraiva, 2011. p. 40.

${ }^{399}$ FERREIRA FILHO, Manoel Gonçalves. Comentários... Op. cit. p. 221.
} 
contas municipais". ${ }^{400}$ Permitiu, no entanto, a criação de novos, desde que os respectivos Municípios contassem com população superior a dois milhões de habitantes e tivessem renda tributária acima de quinhentos milhões de cruzeiros novos ${ }^{401}$. Nenhum, no entanto, foi criado sob a égide dessa Emenda.

O mesmo autor, comentando, agora, o Texto Constitucional de 1988, completa:

\begin{abstract}
"O texto em exame não abre exceções, o que certamente é um erro. As contas dos administradores dos Municípios de grande arrecadação seriam mais atentamente examinadas por tribunal próprio e não sobrecarregariam o órgão estadual incumbido da fiscalização das contas de todos os Municípios, como agora sucede. Quanto às despesas que a instituição de tais tribunais provocaria, os Municípios mais ricos poderiam arcar com elas. Ademais, por que o Estado deve arcar com essa despesa quando o Município tem rendas próprias?". ${ }^{402}$
\end{abstract}

Concordamos com o autor quanto ao fato de "ser um erro" a vedação de criação de novos Tribunais de Contas nos Municípios, nos moldes dos existentes hoje em São Paulo e Rio de Janeiro. A criação de ditos Tribunais de Contas, pensamos, reforçaria a autonomia dos Municípios, que teriam órgãos próprios - que são, em nosso entendimento, órgãos constitucionais autônomos -, com a missão de fiscalizar as contas municipais, no exercício do controle externo, exclusivamente de tais Municípios.

Analisamos, em seguida, de que maneira a Constituição Federal de 1988 ampliou as competências do Tribunal de Contas.

\title{
4.4.3. A ampliação da atividade fiscalizadora do Tribunal de Contas
}

Não há dúvidas de que a Constituição Federal de 1988 alargou sobremaneira a atividade e as competências do Tribunal de Contas.

\footnotetext{
400 Emenda Constitucional $\mathrm{n}^{\mathrm{o}} 1$, de 17 de outubro de 1969. Disponível em: <http://www.planalto.gov.br/ccivil_03/constituicao/emendas/emc_anterior1988/emc01-69.htm>, acesso em 06 de nov. 2011.

${ }^{401} \mathrm{O}$ artigo 16, $\S 3^{\circ}$, da Emenda Constitucional n ${ }^{\circ}$ 1, de 17 de outubro de 1969 dispunha: "Art. 16 (...). $\S 3^{\circ}$ Sòmente poderão instituir Tribunais de Contas os municípios com população superior a dois milhões de habitantes e renda tributária acima de quinhentos milhões de cruzeiros novos". Emenda Constitucional n ${ }^{\circ} 1$, $\begin{array}{llllll}\text { de } & 17 & \text { de } & \text { outubro } & \text { de } & \text { Disponível }\end{array}$ http://www.planalto.gov.br/ccivil_03/constituicao/emendas/emc_anterior1988/emc01-69.htm>, acesso em 06 de nov. 2011.

${ }^{402}$ FERREIRA FILHO, Manoel Gonçalves. Comentários... Op. cit. p. 221.
} 
A razão para tal ampliação deve-se ao retorno da democracia ${ }^{403}$ ao cenário pátrio, o que fez com que o Tribunal de Contas, enquanto órgão de controle, voltasse a ter funções importantes em seara nacional.

Assim, de órgão dependente ${ }^{404}$, no regime militar que vigia durante a Carta de 1967, com a redação da Emenda n 1, de 17 de outubro de 1969, o Tribunal de Contas alcança, novamente, papel de destaque ao apresentar-se como verdadeiro órgão técnico para que a verba pública utilizada pelo Prefeito e pelos gestores públicos possa ser controlada.

Várias são as ampliações verificadas na função de controle do Tribunal de Contas trazidas pela Constituição de 1988.

Uma delas consiste no aumento das fiscalizações contábil, financeira e orçamentária do Tribunal de Contas, podendo, por iniciativa própria, realizar auditorias tanto nas unidades administrativas do Poder Executivo como nas do Poder Legislativo e nos entes despersonalizados. Com isso, o órgão deixa de ter atuação somente passiva (porque só analisava as contas) e passa a ter atuação ativa (pode instaurar auditorias e inspeções) para a análise das contas municiais.

Outra novidade consiste na realização de qualquer espécie de controle (de legalidade, de legitimidade, de economicidade, de aplicação de subvenções e de renúncia de receitas) que, além disso, pode ser prévio, concomitante ou posterior, de acordo com a discricionariedade do próprio Tribunal.

Cuidando dos controles de legitimidade e de economicidade perseguidos pelo Tribunal de Contas, Marcelo Figueiredo estabelece a relação entre eles e o princípio da moralidade administrativa. Aduz o autor:

“(...) de que modo o Tribunal de Contas deve ou pode controlar o princípio da moralidade administrativa? Estará esse controle ínsito na

\footnotetext{
${ }^{403}$ Edna Delmondes bem retratou o panorama de decadência das atribuições do Tribunal de Contas à época da vigência da Carta de 1967: "com essa Carta, o sistema de controle sofreu reveses, enfrentando o Tribunal de Contas a perda de suas competências e supressão de atribuições que somente com a Constituição de 1988 vieram a ser restauradas. DELMONDES, Edna. Op. cit. pp. 43-44.

${ }^{404}$ A dependência do Tribunal de Contas pode ser conferida em Roberto Barcellos de Magalhães. O autor relata que "o contrôle externo, a cargo do Congresso, passa a ser exercido com a coadjuvação do Tribunal de Contas, que assim fica reduzido a uma situação de dependência em relação ao Congresso". MAGALHÃES, Roberto Barcellos de. A Constituição Federal de 1967 comentada Tomo I: arts. 1 a 106. Rio de Janeiro: José Konfino Editor, 1967. p. 216.
} 
fiscalização a respeito da 'legalidade, legitimidade e economidade' a que alude o art. 70, caput, da Constituição Federal?",405

Explica o autor que a obediência ao princípio da moralidade administrativa implica o respeito a dois princípios expressos - o da legitimidade e da economicidade - e, ainda, a um implícito, que é o da razoabilidade. ${ }^{406}$ Quanto à legitimidade, explana que o seu respeito está relacionado à finalidade do ato administrativo. Nas palavras do autor, "na análise da 'legitimidade', cremos que a Constituição pretendeu conferir ao Tribunal de Contas poderes para verificar a adequação dos meios e finalidades do ato administrativo, a fim de sindicar hipóteses de desvio de finalidade ou de poder". ${ }^{407}$ Em relação ao princípio da economicidade objetiva-se "evitar o injustificado prejuízo ao erário". ${ }^{408}$ Finalmente, a obediência ao princípio da razoabilidade está inserta no controle da legitimidade. Explica que as fiscalizações contábil, financeira, orçamentária, operacional e patrimonial sempre deverão ser pautadas pela razoabilidade que, para o autor, se consititui em "verdadeiro pressuposto necessário para empreender os controles de economicidade e legitimidade". 409

Além disso, há uma listagem de competências próprias e taxativas que são apenas do Tribunal de Contas, tal como elencado nos incisos $\mathrm{I}^{410}$ a XI do artigo 71 da Constituição Federal. Esta inovação tem grande importância, por ser inédita. Sobre ela, destaca Eduardo Lobo Botelho Gualazzi:

"Eis uma impressionante inovação para o tema do regime jurídico dos Tribunais de Contas, no Brasil: nunca os Tribunais de Contas Brasileiros dispuseram de competências constitucionais tão amplas e

\footnotetext{
${ }^{405}$ FIGUEIREDO, Marcelo. $O$ controle... Op. cit. p. 94.

${ }^{406}$ Nas palavras do autor: “(...) imaginamos que o cumprimento da moralidade administrativa anda de braços dados com o atendimento a dois princípios expressos e um princípio implícito: os princípis da legitimidade e economicidade (expressos) e o princípio da razoabilidade (implícito)”. Idem. p. 95.

${ }^{407}$ Idem. pp. 95-96.

${ }^{408}$ Idem. p. 98. Quanto ao princípio da economicidade preleciona o autor: "Finalmente, ex vi legis, a violação ao princípio da economidade somente se dará se estiver presente o injustificado prejuízo ao erário". (grifos do autor). Idem. Ibidem.

${ }^{409}$ Idem. p. 99.

${ }^{410}$ A apreciação das contas do Chefe do Executivo não se exaure, no entanto, no Tribunal de Contas. O parecer prévio por ele elaborado é encaminhado ao Poder Legislativo ao qual compete julgá-las. Por outro lado, o Tribunal de Contas não tem competência para sustar contratos. tal tarefa é, também, atribuição do Poder Legislativo (artigo 71, $\S 1^{\circ}$, da Constituição Federal).
} 
incisivas, para desempenho de sua missão, inclusive com listagem taxativa de competências no texto constitucional" ${ }^{111}$ (grifos nossos)

Houve, também, a ampliação do universo de jurisdicionados ${ }^{412}$, para alcançar qualquer pessoa física ou jurídica, pública ou privada que utilize, arrecade, guarde, gerencie ou administre dinheiro público pelos quais o Município responda ou que, em nome dele, assuma obrigações de natureza pecuniária, nos termos do parágrafo único do artigo 70 da Constituição Federal. Sobre o tema assevera o Conselheiro do Tribunal de Contas do Município de São Paulo, Roberto Tanzi Braguim:

"Em 1988, evolução significativa se deu quanto ao papel desses Tribunais, na medida em que, consoante dispõe o artigo 71 da Lei Magna, os Tribunais de Contas, além de terem tido ampliada a base de seus jurisdicionados, passaram a atuar também de forma preventiva, pois, com sua missão constitucional fortalecida, o exame profilático passou à condição de impostergável". ${ }^{413}$

Igualmente, procedeu-se à mudança na forma de escolha ${ }^{414}$ dos Conselheiros (no caso dos Municípios) que compõem a Corte de Contas.

Além disso, a partir de 1988, as correções que o Tribunal de Contas solicita nas auditorias que realiza não podem mais ser anuladas pelo Poder Executivo. ${ }^{415}$

Importante característica é a possibilidade de o Tribunal de Contas aplicar pena ${ }^{416}$ de multa e de advertência ao administrador ou funcionário; além disso, pode determinar a reposição do dinheiro ao erário.

${ }^{411}$ GUALAZZI, Eduardo Lobo Botelho. Op. cit. p. 173.

${ }^{412}$ É o caso, por exemplo, de as sociedades de economia mista, que também devem prestar contas.

${ }^{413}$ BRAGUIM, Roberto Tanzi. Tribunais de Contas: presente e futuro. In: TCM 40: edição comemorativa dos 40 anos do Tribunal de Contas do Município de São Paulo. São Paulo: Imprensa Oficial do Estado de São Paulo, 2008. p. 36.

${ }^{414}$ Em âmbitos federal e estaduais falava-se em Ministros do Tribunal de Contas. Na esfera municipal, em Conselheiros. Assim, até 1967 os Ministros do Tribunal de Contas da União eram escolhidos exclusivamente pelo Presidente da República. A partir da Constituição Federal de 1988 a escolha passou a ser do Presidente da República e do Congresso Nacional. Por ser norma de transposição obrigatória, atualmente, os cinco Conselheiros do Tribunal de Contas do Município de São Paulo (são sete no Município do Rio de Janeiro) são escolhidos por indicações do Prefeito e da Câmara Municipal. Este tópico será melhor estudado no item 4.4.5 (A sua composição).

${ }^{415}$ Edna Delmondes é quem explica: "A independência do Tribunal foi confirmada, sendo retirada a herança autoritária da ditadura militar. A partir da Constituição de 1988, as correções solicitadas pelo Tribunal no curso das auditorias e inspeções não mais podem ser anuladas pelo Poder Executivo". DELMONDES, Edna. Op. cit. p. 50.

${ }^{416}$ Estas penalidades são previstas nos artigos 52 a 55 da Lei $n^{\circ}$ 9.167, de 03 de dezembro de 1980 alterada pela Lei no 13.877, de 23 de julho de 2004. (Lei Orgânica do Tribunal de Contas do Município de São Paulo. 
Deve ser ressaltada, ainda, a aproximação do Tribunal de Contas com a sociedade, na medida em que qualquer cidadão, partido político, associação ou sindicato pode denunciar irregularidades ou ilegalidades ao Órgão de Contas, nos termos do $\S 2^{\circ}$, do artigo 74, da Constituição Federal.

Todas estas novidades na atividade fiscalizadora do Tribunal de Contas levam Eduardo Lobo Botelho Gualazzi a pronunciar:

"Em relação à Constituição anterior, a atual Constituição do Brasil, de 1988, apresenta 'notável evolução', no sentido de fortalecer e dignificar, jurídica e politicamente, a atividade de controle externo,

Para detalhes, consultar: BRASIL. Lei $\mathrm{n}^{\circ}$ 9.167, de 03 de dezembro de 1980. Trata da Lei Orgânica do Tribunal de Contas do Município de São Paulo. Disponível em: <http://www.tcm.sp.gov.br/legislacao/lorgtcm/loc_t1.htm>, acesso em 10 de jan. 2012 e BRASIL. Lei ${ }^{\circ}$ 13.877, de 23 de julho de 2004. Dispõe sobre a reorganização administrativa do Tribunal de Contas do Município de São Paulo e de seu Quadro de Pessoal, altera dispositivos das Leis no 9.167, de 3 de dezembro de 1980 e n n $^{\circ} 11.548$, de 21 de junho de 1994, procede às adaptações necessárias às normas da EC 19/98 e 20/98 e dá outras providências. Disponível em: <http://www.tcm.sp.gov.br/legislacao/lorgtcm/13877.htm, acesso em 10 de jan. 2012>. Nosso Tribunal é, no entanto, o mais "atrasado" com relação à legislação de multas e sanções. A Lei Orgânica do Tribunal de Contas dos Municípios do Estado de Goiás permite ao Tribunal de Contas, por exemplo, por decisão da maioria absoluta de seus membros e, se o Tribunal considerar grave a infração cometida, declarar o responsável inabilitado, pelo período de cinco a oito anos, para o exercício de cargo em comissão ou função de confiança no âmbito da Administração Pública municipal (artigo 50). Também pode, no caso de fraude comprovada à licitação, declarar a inidoneidade do licitante fraudador para participar, por até cinco anos, de licitação na Administração Pública municipal (artigo 51). Pode, ainda, em âmbito de medida cautelar: de ofício ou a requerimento do Ministério Público junto ao Tribunal, decretar o afastamento temporário do responsável que, no exercício de suas funções, esteja retardando ou dificultando a realização de auditorias e inspeções pelo Tribunal de Contas, causar novos danos ao erário ou inviabilizar o seu ressarcimento (artigo 53); decretar a indisponibilidade dos bens do responsável por até um ano (artigo 54) e, através do Ministério Público Estadual solicitar à Procuradoria do Município as medidas necessárias para o arresto dos bens dos responsáveis julgados em débito, devendo, nesta hipótese, ser ouvido quanto à liberação dos bens arrestados e sua restituição (artigo 55). Todos estes artigos são da Lei no 15.958 , de 18 de janeiro de 2007 (Lei Orgânica do Tribunal de Contas dos Municípios do Estado de Goiás). BRASIL. Lei no 15.958, de 18 de janeiro de 2007, com as alterações da Lei $\mathrm{n}^{\mathrm{o}}$ 16.467, de 5 de maneiro de 2009 e da Lei $\mathrm{n}^{\circ}$ 17.288, de 19 de abril de 2011. Trata da Lei Orgânica do Tribunal de Contas dos Municípios do Estado de Goiás. Disponível em: 〈http://www.tcm.go.gov.br/site/legislacao/indexLegislacao.jsf $>$, acesso em 10 de jan. 2012. Dispositivos semelhantes são encontrados na Lei $\mathrm{n}^{\circ} 16.168$, de 11 de dezembro de 2007. Para detalhes, consultar: BRASIL. Lei ${ }^{\circ} 16.168$, de 11 de dezembro de 2007, com as alterações da Lei $\mathrm{n}^{\circ} 16.925$, de 02 de março de 2010 e da Lei n 17.260, de 26 de janeiro de 2011. Trata da Lei Orgânica do Tribunal de Contas do Estado de Goiás. Disponível

em: <http://tcenet.tce.go.gov.br/Downloads/Arquivos/000100/Lei\%20organica\%203.0.pdf>, acesso em 10 de jan. 2012; na Lei Complementar n 269, de 22 de janeiro de 2007 (Lei Orgânica do Tribunal de Contas do Estado de Mato Grosso). Para detalhes, consultar: BRASIL. Lei Complementar n ${ }^{\circ}$ 269, de 22 de janeiro de 2007. Trata da Lei Orgânica do Tribunal de Contas do Estado de Mato Grosso. Disponível em: <http://www.tce.mt.gov.br/legislacao?categoria=4>, acesso em 10 de jan. 2012; na Lei Complementar ${ }^{\circ}$ 48, de 28 de junho de 1990 (Lei Orgânica do Tribunal de Contas do Estado do Mato Grosso do Sul). Para detalhes, consultar: BRASIL. Lei Complementar n $\mathrm{n}^{\circ}$ 48, de 28 de junho de 1990, com as alterações da Lei Complementar $\mathrm{n}^{\circ}$ 117, de 2005. Trata da Lei Orgânica do Tribunal de Contas do Estado do Mato Grosso do Sul. Disponível em <http://www.tce.ms.gov.br/portal//egislacao_servico_consulta>, acesso em 10 de jan. 2012; Lei Complementar no 01, de 9 de maio de 1994 (Lei Orgânica do Tribunal de Contas do Distrito Federal). Disponível no site: <http://www.tc.df.gov.br/web/site/biblioteca-de-documentos>, acesso em 10 de jan. 2012. 
concentrando-a nos Tribunais de Contas: neste aspecto, a Constituição da República, de 1988, transpôs para a área de controle interno e externo os princípios da legalidade, impessoalidade, moralidade e publicidade, que regem a Administração Pública Brasileira, de acordo com o art. 37 ('caput') de nossa atual Carta Magna". ${ }^{417}$ (grifos nossos)

Como se observa, a Constituição de 1988 cuidou com atenção do Tribunal de Contas, não somente conferindo-lhe mais competências do que as previstas durante o regime militar, dando-lhe autonomia para decidir quando e em quais circunstâncias uma auditoria deve ser iniciada, como, também, permitindo-lhe, sancionar os responsáveis que não utilizarem o dinheiro público a contento.

Delineia-se, assim, de antemão, a importância do Órgão de Contas no cenário pátrio, no sentido de cuidar para que o dinheiro público seja bem empregado pelo gestor público e, uma vez utilizado, para verificar se o recurso foi bem empregado. O órgão serve, pois, para o controle das finanças públicas, que, como já se explanou, é atribuição do povo.

\subsubsection{As competências constitucionais e os tipos de contas}

As competências constitucionais do Tribunal de Contas, como se disse, estão taxativamente previstas nos incisos I a XI do artigo 71 da Constituição Federal de 1988. São, ademais, competências somente do Tribunal de Contas. A única exceção ${ }^{418}$ é a do inciso I do artigo 71. A competência lá descrita - apreciar as contas do Prefeito mediante a elaboração de um parecer prévio - é também exclusiva do Tribunal de Contas, entretanto, ela não se exaure na Corte de Contas. É que o parecer prévio é encaminhado para a Câmara Municipal, à qual compete o julgamento final do Prefeito, incidindo, conforme o resultado desse julgamento, a inelegibilidade prevista no artigo $1^{\circ}$, I, "g", da Lei Complementar no 64/90 com redação dada pela Lei Complementar no 135/10 (Lei da "Ficha Limpa").

Esta é, sem dúvida, a competência mais importante do Tribunal de Contas e se efetua através da análise das chamadas contas de governo. É, também, a competência que merecerá nossa analise pormenorizada no Capítulo seguinte.

\footnotetext{
${ }^{417}$ GUALAZZI, Eduardo Lobo Botelho. Op. cit. p. 173.

${ }^{418}$ Também se caracteriza como exceção a sustação dos contratos, que é competência do Poder Legislativo. Está, no entanto, prevista no $\S 1^{\circ}$ do artigo 71 e não nos incisos I a XI do mesmo artigo.
} 
Antes, porém, de adentrarmos no tema - a apreciação das contas anualmente prestadas pelo Prefeito -, é preciso salientar que existem três tipos de contas analisadas no âmbito Tribunal de Contas em cenário pátrio: as contas de governo, relativas aos atos de governo (também chamados atos políticos) examinadas quando o Tribunal de Contas, anualmente, aprecia as contas do Prefeito, elaborando um parecer prévio, que é submetido a julgamento político na Câmara Municipal; as relacionadas aos atos de gestão $^{419}$, competindo, nestes casos, ao Tribunal de Contas, realizar o julgamento das contas dos administradores e demais responsáveis pelo dinheiro público; e a prestação de contas especial. A primeira e a segunda decorrem, respectivamente, dos incisos I e II do artigo 71 da Constituição Federal.

A prestação de contas especial, por seu turno, é instaurada quando "há suspeita de existência de desfalques, desvios de dinheiros, de valores ou de bens públicos, ou da prática de ato antieconômico de que resulte dano ao erário". ${ }^{420}$ Nestas hipóteses, o Tribunal de Contas fixa prazo para que o gestor público preste suas contas.

Pode ocorrer, também, de o gestor público omitir-se quanto ao seu dever constitucional de apresentar as contas. É que, como regra, a prestação de contas à Corte de Contas é ato voluntário do gestor público. Não o fazendo, isto é, sendo omisso, o Tribunal de Contas, de acordo com o que dispõe o inciso IX do artigo 71 da Constituição Federal, fixa prazo para o gestor público apresentá-las. Se, ainda assim, o gestor quedar-se inerte, o Tribunal de Contas instaura a tomada de contas especial para sanar o problema.

Registre-se, por oportuno, que o nome técnico da prestação de contas de governo é balanço. Daí porque se fala em Balanço Geral do Executivo para

\footnotetext{
${ }^{419}$ As contas de gestão, por outro lado, servem para analisar as contas prestadas por todos os demais gestores públicos, à exceção do Chefe do Executivo que, como se viu, responde pelas contas de governo. O gestor público, depois de ter utilizado, arrecadado, guardado, gerenciado ou administrado dinheiro público tem o dever de prestar contas do recurso que ficou sob sua responsabilidade e o faz ao Tribunal de Contas, que tem a competência de julgá-las. Nos dizeres de Afonso Gomes Aguiar e Márcio Paiva de Aguiar, "estamos, pois, diante de documento pelo qual os gestores públicos submetem a exame e julgamento dos Tribunais de Contas, os resultados específicos da administração financeira das unidades orçamentárias, posta em prática mediante seus atos administrativos de gestão orçamentária, financeira, patrimonial e operacional, durante um determinado exercício financeiro. As autoridades administrativas (ou seus ordenadores de despesas) somente se exonerarão de suas responsabilidades após o julgamento do Tribunal de Contas que se converta em aprovação das respectivas prestações de contas". AGUIAR, Afonso Gomes; AGUIAR, Márcio Paiva de. $O$ Tribunal de Contas na ordem constitucional. $2^{\mathrm{a}}$ ed. Belo Horizonte: Fórum, 2008. p. 19.

${ }^{420}$ AGUIAR, Afonso Gomes; AGUIAR, Márcio Paiva de. Op. cit. p. 20.
} 
representar as contas prestadas pelo Prefeito e que englobam os gastos referentes apenas ao Poder Executivo ${ }^{421}$.

Definidos os tipos de contas, passaremos, no próximo tópico, a estudar as características da apreciação das contas de governo pelo Tribunal de Contas, mediante a elaboração do parecer prévio.

\subsubsection{A apreciação das "contas de governo" anualmente prestadas pelo Prefeito mediante a elaboração de um parecer prévio}

Inicialmente, é preciso consignar que a Constituição Federal estabelece o dever de o Presidente da República e, por simetria constitucional, Governador e Prefeito de prestarem contas, anualmente, ao Poder Legislativo respectivo, no prazo de sessenta dias após a abertura da sessão legislativa, referentes ao exercício anterior (artigo $\left.84, \mathrm{XXIV}^{422}\right)$.

\footnotetext{
${ }^{421}$ O Balanço Geral do Executivo não abrange, pois, como consta do artigo 56 da Lei federal no 101 , de 04 de maio de 2000 (Lei de Responsabilidade Fiscal), as contas dos Poderes Legislativo e Judiciário e do Ministério Público. Estas devem ser prestadas ao Tribunal de Contas, que as julgará, de acordo com o inciso II do artigo 71 da Constituição Federal. As do Prefeito, por outro lado e na exegese do inciso I do artigo 71, são apreciadas pelo Tribunal de Contas mediante a elaboração de um parecer prévio, porém, julgadas pela Câmara dos Vereadores. O artigo 56, da Lei federal no 101, de 4 de maio de 2000 (conhecida como Lei de Responsabilidade Fiscal) foi objeto da Ação Direta de Inconstitucionalidade no 2238/DF. O artigo 56 citado dispõe que: "Art. 56. As contas prestadas pelos Chefes do Poder Executivo incluirão, além das suas próprias, as dos Presidentes dos órgãos dos Poderes Legislativo e Judiciário e do Chefe do Ministério Público, referidos no art. 20, as quais receberão parecer prévio, separadamente, do respectivo Tribunal de Contas". O que se discutiu, e que foi deferido em sede de cautelar, é que a as contas dos Chefes dos Poderes Legislativo e Judiciário, bem como as do Ministério Público não podem apenas receber um parecer prévio do Tribunal de Contas, porque isso contraria o disposto no inciso II do artigo 71 da Constituição Federal que determina que todas as demais contas dos administradores em geral, - onde se incluem as contas dos Chefes dos Poderes Legislativo e Judiciário e as do Ministério Público - à exceção das do Chefe do Executivo, serão julgadas pelo Tribunal de Contas. Med. Caut. em Ação Direta de Inconstitucionalidade 2.238-5/Distrito Federal. Rel. Original Min. Ilmar Galvão. Rel. para o acórdão Min. Carlos Ayres Britto. Tribunal Pleno. No tocante ao artigo 56, caput, cautelar deferida, à unanimidade, nos votos do Relator. Julgado em 09/08/07 e publicado no Diário Oficial da União de 12/09/08. Disponível em <http://redir.stf.jus.br/paginadorpub/paginador.jsp?docTP=AC\&docID=547193>, acesso em 31 de out. 2011. ${ }^{422}$ Art. 84. Compete privativamente ao Presidente da República: XXIV - prestar, anualmente, ao Congresso Nacional, dentro de sessenta dias após a abertura da sessão legislativa, as contas referentes ao exercício anterior”. BRASIL. Constituição (1988). Constituição da República Federativa do Brasil: promulgada em 5 de outubro de 1988: atualizada até a Emenda Constitucional no 67, de 22-12-2010. 45ª ed. ampl. São Paulo: Saraiva, 2011. p. 75.
} 
Soma-se, a esta disposição, o prescrito no artigo 71, I, da Constituição Federal que, também por simetria constitucional e por disposição do artigo $75^{423}$ da Lei Maior, aplica-se ao Tribunal de Contas, no âmbito dos Municípios:

“Art. 71. O controle externo, a cargo do Congresso Nacional, será exercido com o auxílio do Tribunal de Contas da União, ao qual compete: I - apreciar as contas prestadas anualmente pelo Presidente da República, mediante parecer prévio que deverá ser elaborado em sessenta dias a contar de seu recebimento". ${ }^{424}$

De outra banda, a teor do disposto no referido artigo 84, XXIX, da Lei Maior, o Presidente da República, no prazo de sessenta dias após a abertura da sessão legislativa, deve apresentar ao Congresso Nacional as contas do exercício anterior.

De cotejo dos dois dispositivos citados verifica-se: 1) a obrigatoriedade de o Prefeito prestar, anualmente, à Câmara Municipal, as contas referentes ao exercício anterior, no prazo determinado de sessenta dias da abertura da sessão legislativa e 2) a obrigatoriedade de o Tribunal de Contas, também em sessenta dias, apreciar, isto é, examinar as contas prestadas pelo Presidente da República, mediante a elaboração de um parecer prévio que é, por excelência, técnico, eis que preparado por auditores, contadores, engenheiros, acerca das contas de governo do Prefeito, isto é, incidente sobre toda a gestão do Prefeito durante o ano. Entram nesta análise, por exemplo, os gastos com passagens de ônibus, merenda escolar, hospitais públicos e etc. Há, portanto, uma obrigação para o Prefeito, enquanto Chefe do Executivo municipal e outra obrigação para o Tribunal de Contas, como órgão de controle das contas municiais. Nenhum dos dois pode, assim, deixar de cumprir o seu mister constitucional. Ressalte-se que, no Município de São Paulo, esse prazo do Tribunal para apreciar as contas, é de noventa dias (artigo 48, $\mathrm{I}^{425}$, da Lei Orgânica).

\footnotetext{
${ }^{423} \mathrm{O}$ artigo 75 da Constituição Federal dispõe: "Art. 75. As normas estabelecidas nesta seção aplicam-se, no que couber, à organização, composição e fiscalização dos Tribunais de Contas dos Estados e do Distrito Federal, bem como dos Tribunais e Conselhos de Contas dos Municípios". BRASIL. Constituição (1988). Constituição da República Federativa do Brasil: promulgada em 5 de outubro de 1988: atualizada até a Emenda Constitucional n ${ }^{\circ}$ 67, de 22-12-2010. $45^{\mathrm{a}}$ ed. ampl. São Paulo: Saraiva, 2011. p. 72.

${ }^{424}$ BRASIL. Constituição (1988). Constituição da República Federativa do Brasil: promulgada em 5 de outubro de 1988: atualizada até a Emenda Constitucional no 67, de 22-12-2010. 45 a ed. ampl. São Paulo: Saraiva, 2011. p. 71.

425 "Art. 48. O controle externo, a cargo da Câmara Municipal, será exercido com o auxílio do Tribunal de Contas do Município de São Paulo, ao qual compete: I - apreciar as contas prestadas anualmente pelo Prefeito, pela Mesa da Câmara e pelo próprio Tribunal, mediante parecer prévio que deverá ser elaborado em
} 
Importante anotar que, enquanto o Prefeito e o Tribunal de Contas têm prazos determinados - sessenta e noventa dias - para apresentar e apreciar as contas, respectivamente, o mesmo não se observa em relação ao Poder Legislativo, já que a Constituição silenciou quanto à fixação de um prazo para tal Poder julgar as contas prestadas pelo Chefe do Executivo municipal. Justifica-se a ausência de prazo pelo princípio da separação de Poderes.

De outra parte, discorrendo sobre esta competência, Diogo de Figueiredo Moreira Neto ${ }^{426}$ aduz tratar-se ela de uma competência autônoma do Tribunal de Contas, realçando que no parecer prévio estão em análise não apenas a legalidade e a economicidade dos atos, como também a legitimidade deles, existindo, assim, margem para a discricionariedade na emissão do parecer prévio.

Julio Cesar Manhães de Araújo ${ }^{427}$, por sua vez, bem esclarece que o Tribunal de Contas deve elaborar parecer prévio apenas das contas do Prefeito, porque o seu julgamento ocorre na Câmara dos Vereadores. As contas do Poder Legislativo ${ }^{428}$, portanto, não merecem apreciação mediante um parecer prévio, devendo ser julgadas pelo Tribunal de Contas, de acordo com o inciso II do artigo 71 da Constituição Federal.

90 (noventa) dias, a contar da data de seu recebimento, que terá seu termo final em 31 de março de cada exercício". BRASIL. Lei Orgânica do Município de São Paulo: atualizada com a Emenda Constitucional no 28/2006. José Fernando Ferreira Brega (Org.). São Paulo: Páginas \& Letras Editora e Gráfica: Associação dos Procuradores do Município de São Paulo, 2006. p. 37.

${ }^{426}$ MOREIRA NETO, Diogo de Figueiredo. Op. cit. p. 112.

${ }^{427}$ ARAÚJO, Julio Cesar Manhães de. Op. cit. pp. 291-292.

428 Ementa da Ação Direta de Inconstitucionalidade no 1779/PE-MC: "AÇÃO DIRETA DE INCONSTITUCIONALIDADE. MEDIDA CAUTELAR. CONSTITUIÇÃO DO ESTADO DE PERNAMBUCO. TRIBUNAIS DE CONTAS. LIMITAÇÃO DE SEUS PODERES. AMPLIAÇÃO DOS PODERES DO PODER LEGISLATIVO. DIVERGÊNCIA COM O MODELO FEDERAL. CAUTELAR DEFERIDA. As disposições da Carta estadual impugnadas, contrariando o modelo jurídico federal, de observância obrigatória pelos Estados, como deriva da cláusula inscrita no art. 75, caput, ampliaram a esfera de competência da Mesa da Assembleia Legislativa e da Mesa da Câmara Municipal, investindo-as de poderes para julgar suas próprias contas e ainda as dos Tribunais de Contas do Estado e do Tribunal de Justiça, enquanto, a partir do que contido no âmbito federal, só lhes caberia o julgamento das contas do Governador e do Prefeito. Além do mais, foi conferida aos Tribunais de Contas atuação meramente opinativa em relação às contas prestadas pelo Chefe do Poder Executivo e pelas Mesas das Câmara Municipais, indo de encontro à regra do art. 71, inciso I, da Carta Federal. Precedentes da Corte. Cautelar deferida". Na mesma ADIn, em seu voto, o Min. Ilmar Galvão (Relator), acerca do parecer prévio, refutando o entendimento de que este seria meramente opinativo e sim técnico, assim pronunciou-se: "Além do mais, no art. 86, inc. III e $\S 2^{\circ}$, foi conferida aos Tribunais de Contas atuação meramente opinativa em relação às contas prestadas pelo Chefe do Poder Executivo e pelas Mesas das Câmaras Municipais, indo de encontro à regra do art. 71, I, da Carta Federal, segundo a qual na análise das contas do Chefe do Poder Executivo emitem os Tribunais de Contas pronunciamento técnico, sem conteúdo deliberativo, consubstanciado em parecer prévio, com o fim de subsidiar o exercício das atribuições fiscalizadoras do Poder Legislativo, que a essa manifestação não está obrigado a se vincular". Ação Direta de Inconstitucionalidade no 1779-1/Pernambuco. Rel. Min. Ilmar Galvão. Tribunal Pleno. Julgado em 23/04/98 e publicado no Diário de Justiça de 22/05/98. Disponível em <http:///www.stf.jus.br>, acesso em 14 de mar. 2008. 
Elaborado o parecer prévio, deve ele ser encaminhado à Câmara Municipal, para que realize o julgamento das contas municipais apresentadas pelo Prefeito. É pelo fato de o Parlamento representar o povo que as contas de governo devem ser por ele julgadas, já que a Casa Legislativa é o locus $^{429}$ onde se reúnem os representantes do povo.

O julgamento, ademais, é político e, pois, baseado na conveniência e oportunidade do Parlamento. Significa, então, que a Câmara Municipal pode derrubar o parecer prévio que rejeitou as contas do Prefeito, elaborado pela Corte de Contas, contudo, para isso, são necessários os votos de, pelo menos, dois terços dos seus membros, tal como determina o $\S 2^{\circ}$ do artigo 31 da Constituição Federal: “o parecer prévio, emitido pelo órgão competente sobre as contas que o Prefeito deve anualmente prestar, só deixará de prevalecer por decisão de dois terços dos membros da Câmara Municipal". 430

Questão interessante surgida com a promulgação da Lei Complementar $n^{\circ}$ 135/10, conhecida como a Lei da "Ficha Limpa", diz respeito a saber se a rejeição das contas do Prefeito pelo Tribunal de Contas, no âmbito municipal, é capaz de gerar a sua inelegibilidade (artigo $1^{\circ}$, I, alínea “g”, da Lei Complementar no 64/90) para concorrer a outros cargos públicos.

Impende ressaltar, por primeiro, que a promulgação da Lei da "Ficha Limpa" fez com que diversos Prefeitos, cujas contas tinham sido rejeitadas pelo Tribunal de Contas, recorressem ao Poder Judiciário, alegando que o julgamento das contas de governo faz-se pela Câmara Municipal, cabendo ao Tribunal de Contas auxiliá-la mediante a elaboração do parecer prévio, que não tem o condão de torná-lo inelegível.

É que dispõe o $\operatorname{artigo~} 1^{\circ}$, I, “g”, da Lei Complementar no 64/90 com redação dada pela Lei Complementar n ${ }^{\circ}$ 135/10:

"Art. $1^{\circ}$. São inelegíveis:

I - para qualquer cargo:

\footnotetext{
${ }^{429}$ Monica Herman Salem Caggiano é quem utiliza a expressão "lócus de representação política" para o Parlamento. De acordo com a autora: "Tem sabor de lugar-comum, porém nos parece importante frisar que a primeira das atribuições parlamentares foi a da representação política, cuja relevância permanece até os nossos dias por todos assinalada, conduzindo, no entanto, como em todos os tempos, a questionamentos cada vez mais complexos e de difícil solução". CAGGIANO, Monica Herman Salem. Direito... Op. cit. p. 13.

${ }^{430}$ BRASIL. Constituição (1988). Constituição da República Federativa do Brasil: promulgada em 5 de outubro de 1988: atualizada até a Emenda Constitucional no 67, de 22-12-2010. 45 a ed. ampl. São Paulo: Saraiva, 2011. p. 40.
} 
g) os que tiverem suas contas relativas ao exercício de cargos ou funções públicas rejeitadas por irregularidade insanável que configure ato doloso de improbidade administrativa, e por decisão irrecorrível do órgão competente, salvo se esta houver sido suspensa ou anulada pelo Poder Judiciário, para as eleições que se realizarem nos 8 (oito) anos seguintes, contados a partir da data da decisão, aplicando-se o disposto no inciso II do art. 71 da Constituição Federal, a todos os ordenadores de despesa, sem exclusão de mandatários que houverem agido nessa condição" ${ }^{431}$ (grifos nossos)

A questão foi decidida pelo Tribunal Superior Eleitoral que, ao responder à consulta $\mathrm{n}^{\circ} 112026 / \mathrm{DF}^{432}$ entendeu que a Lei da "Ficha Limpa" se aplicava às eleições de 2010. A jurisprudência que analisaremos a seguir foi elaborada, então, antes de o Supremo Tribunal Federal julgar o Recurso Extraordinário nº 633.703/Minas Gerais ${ }^{433}$, que entendeu que a mencionada Lei não poderia se aplicar às eleições de 2010, mas serve para nossa análise, porque nela se discute se a rejeição das contas do Prefeito pelo Tribunal de Contas pode ou não causar a inelegibilidade de que trata o artigo $1^{\circ}$, I, "g", da Lei Complementar $n^{\circ}$ 64/90:

\footnotetext{
"Eleições 2010. Agravo regimental em recurso ordinário. Inelegibilidade por rejeição de contas (art. $1^{\circ}$, inc. I, "g", da Lei Complementar $n$. 64/90). Não caracterização. Ex-prefeito municipal. À exceção de contas relativas a convênios, a desaprovação das contas de prefeito pelo Tribunal de Contas não atrai a incidência da inelegibilidade do art. $1^{\circ}$, inc. I, "g", da Lei Complementar $n^{\circ}$ 64/90, mesmo após a
}

431 BRASÍLIA (BR). Lei Complementar $n^{\circ}$ 64, de 18 de maio de 1990, com redação dada pela Lei Complementar $n^{\circ} 135,4$ de junho de 2010. Estabelece, de acordo com o art. 14, § $9^{\circ}$ da Constituição Federal, casos de inelegibilidade, prazos de cessação, e determina outras providências. Diário Oficial da União de 18 de maio de 1990.

${ }^{432}$ Consulta $n^{\circ}$ 112026/DF, Rel. Min. Hamilton Carvalhido, sessão de 10.06.2010. A pergunta da consulta, formulada pelo Senador da República Arthur Virgílio do Carmo Ribeiro Neto, foi: "Uma lei eleitoral que disponha sobre inelegibilidades e que tenha a sua entrada em vigor antes do prazo de 5 de julho, poderá ser efetivamente aplicada para as eleições gerais de 2010?". Eis o teor da ementa: CONSULTA. ALTERAÇÃO. NORMA ELEITORAL. LEI COMPLEMENTAR N 135/2010. APLICABILIDADE. ELEIÇÕES 2010. AUSÊNCIA DE ALTERAÇÃO NO PROCESSO ELEITORAL. OBSERVÂNCIA DE PRINCÍPIOS CONSTITUCIONAIS. PRECEDENTES. Consulta conhecida e respondida afirmativamente". Disponível em: 〈http://www.tse.jus.br/jurisprudencia/inteiro-teor>, acesso em 03 de dez. 2011.

${ }^{433}$ Recurso Extraordinário no 633.703/Minas Gerais, Rel. Min. Gilmar Mendes. "Recurso Extraordinário conhecido para: a) reconhecer a repercussão geral da questão constitucional atinente à aplicabilidade da LC $n^{\circ} 135 / 2010$ às eleições de 2010, em face do princípio da anterioridade eleitoral (art. 16 da Constituição), de modo a permitir aos Tribunais e Turmas Recursais do país a adoção dos procedumentos relacionados ao exercício de retratação ou declaração de inadmissibilidade dos recursos repetitivos, sempre que as decisões recorridas contrariarem ou se pautarem pela orientação ora firmada; b) dar provimento ao recurso, fixando a não aplicabilidade da Lei Complementar $n^{\circ}$ 135/2010 às eleições gerais de 2010”. Julgado em 23/03/11 e publicado no diário de Justiça de 18/11/11. Disponível em: <http://redir.stf.jus.br/paginadorpub/paginador.jsp?docTP=AC\&docID=629754>, acesso em 19 de dez. 2011. 
vigência da Lei Complementar $\mathrm{n}^{\circ}$ 135/2010. Precedentes. Agravo regimental ao qual se nega provimento". ${ }^{434}$ (grifos nossos)

Trata-se, no caso, de ex-Prefeito que teve as suas contas rejeitadas pelo Tribunal de Contas do Estado do Ceará que, no parecer prévio, concluiu pela ocorrência de irregularidades insanáveis que caracterizavam atos dolosos de improbidade administrativa, aptos a causarem a inelegibilidade prevista no artigo $1^{\circ}$, I, "g", da Lei Complementar $n^{\circ}$ 64/90. O ex-Prefeito não conseguiu registrar a sua candidatura ao cargo de deputado federal para as eleições de 2010 pelo Estado do Ceará e, por isso, recorreu à Justiça.

A Sra. Ministra Relatora Cármen Lúcia deu razão ao ex-Prefeito e fundamentou sua decisão, entre outros, no Recurso Ordinário n ${ }^{\circ} 75179 / \mathrm{TO}$, cuja ementa tem o seguinte teor:

"Registro. Inelegibilidade. Rejeição de contas. Órgão competente.

1. Nos termos do art. 31 da Constituição Federal, a competência para o julgamento das contas de Prefeito é da Câmara Municipal, cabendo ao Tribunal de Contas a emissão de parecer prévio, o que se aplica, inclusive, a eventuais atos de ordenação de despesas.

2. A ressalva final constante da nova redação da alínea "g" do inciso I do art. $1^{\circ}$ da Lei Complementar n. 64/90, introduzida pela Lei Complementar n. 135/2010 - de que se aplica 'o disposto no inciso II do art. 71 da Constituição Federal, a todos os ordenadores de despesa, sem exclusão de mandatários que houverem agido nessa condição' -, não alcança os chefes do Poder Executivo.

3. Os Tribunais de Contas só têm competência para julgar as contas de Prefeito quando se trata de fiscalizar a aplicação de recursos mediante convênios (art. 71, inc. VI, da Constituição Federal)." ${ }^{\text {"35 }}$ (grifos nossos)

Como se depreende, o Tribunal Superior Eleitoral firmou entendimento no sentido de que o parecer prévio do Tribunal de Contas, que rejeitou as contas do Prefeito, ainda que embasado em prática de atos de improbidade administrativa

\footnotetext{
${ }^{434}$ Agravo Regimental no Recurso Ordinário no 4176-02.2010.6.06.0000 - Classe 37 - Fortaleza - Ceará. Rel. Min. Cármen Lúcia Antunes Rocha. Negado provimento ao Agravo Regimental, v. u., julgado em 03/02/2011. Disponível em <http://www.tse.jus.br/jurisprudencia/pesquisa-de-jurisprudencia>, acesso em 03 de dez. 2011.

${ }^{435}$ Recurso Ordinário no 75179/TO, Rel. Min. Arnaldo Versiani Leite Soares, sessão 08/09/10. Disponível em: <http://www.tse.jus.br/jurisprudencia/pesquisa-de-jurisprudencia>, acesso em 03 de dez. 2011. Decisões no mesmo sentido, também citados pela Rel. Min. Cármen Lúcia Antunes Rocha são o AGR-RO n 249184/BA, Rel. Min. Marcelo Ribeiro, sessão 06/10/2010 e o RO n 241213/MT, REl. Min. Arnaldo Versiani, sessão de 29/09/2010.
} 
insanáveis, não é apto para, sozinho, causar a inelegibilidade prevista no artigo 1", I, "g", da Lei Complementar n ${ }^{\circ}$ 64/90 com a redação dada pela Lei Complementar no 135/10.

Abordaremos, em seguida, o inciso II do artigo 71 da Constituição Federal e teceremos considerações sobre as diferenças deste com o inciso I, analisado neste tópico.

\subsubsection{O julgamento das "contas de gestão" dos administradores e responsáveis pelo dinheiro público}

A competência do Tribunal de Contas para o julgamento (e não apreciação) das contas de gestão encontra-se no inciso II do artigo 71 da Constituição Federal, que dispõe:

\footnotetext{
"Art. 71. O controle externo, a cargo do Congresso Nacional, será exercido com o auxílio do Tribunal de Contas da União, ao qual compete: II - julgar as contas dos administradores e demais responsáveis por dinheiros, bens e valores públicos da administração direta e indireta, incluídas as fundações e sociedades instituídas e mantidas pelo Poder Público federal, e as contas daqueles que derem causa a perda, extravio ou outra irregularidade de que resulte prejuízo ao erário público". ${ }^{436}$ (grifos nossos)
}

Depreende-se que todo aquele que utilizar dinheiro público em âmbito municipal, à exceção do Prefeito, terá as suas contas julgadas pelo Tribunal de Contas. Isso acontece porque o todo patrimônio público deve ser submetido a controle. Como profere Marianna Montebello Willeman, "sendo pública a origem do bem administrado ou do dinheiro gerido, surge para o gestor o dever de comprovar a boa administração, submetendo-se à fiscalização interna e externa". ${ }^{437}$ E complementam Afonso Gomes Aguiar e Márcio Paiva de Aguiar, explicando a finalidade das contas de gestão: "estamos, pois, diante de documento pelo qual os gestores públicos submetem a exame e julgamento dos Tribunais de Contas, os resultados específicos da administração financeira das unidades orçamentárias, posta em prática mediante seus atos administrativos

\footnotetext{
${ }^{436}$ BRASIL. Constituição (1988). Constituição da República Federativa do Brasil: promulgada em 5 de outubro de 1988: atualizada até a Emenda Constitucional no 67, de 22-12-2010. 45 a ed. ampl. São Paulo: Saraiva, 2011. pp. 70-71.

${ }^{437}$ WILLEMAN, Marianna Montebello. O princípio republicano e os Tribunais de Contas. Revista Interesse Público. Ano X, n. 50. Belo Horizonte: jul./ago, 2008. pp. 277-302.
} 
de gestão orçamentária, financeira, patrimonial e operacional, durante um determinado exercício financeiro. As autoridades administrativas (ou seus ordenadores de despesas) somente se exonerarão de suas responsabilidades após o julgamento do Tribunal de Contas que se converta em aprovação das respectivas prestações de contas". ${ }^{38}$

Dadas estas características, é fácil verificar as diferenças existentes entre o disposto nesse inciso e o analisado anteriormente: o Prefeito tem suas contas apreciadas pelo Tribunal de Contas e julgadas pela Câmara Municipal, enquanto que todos os demais administradores públicos, que utilizem dinheiro público, têm suas contas julgadas pelo Tribunal de Contas, que funciona como a última instância de julgamento, excepcionando-se apenas a hipótese de o gestor recorrer ao Poder Judiciário, em face do permissivo constitucional do inciso XXXV do artigo $5^{\circ}$ da Constituição Federal.

Significa, então, que as contas de um administrador, por exemplo, um Secretário de Governo, rejeitadas pelo Tribunal de Contas são, neste caso, capazes de gerar a inelegibilidade do Secretário, caso ele deseje se candidatar às eleições.

Foi o que decidiu o Tribunal Superior Eleitoral em relação à aplicação da Lei Complementar $n^{\circ}$ 64/90, com a redação dada pela Lei Complementar $n^{\circ}$ 135/10 (Lei da "Ficha Limpa") no caso das Eleições de 2010, quando o Supremo Tribunal Federal não tinha ainda firmado posicionamento sobre a validade ou não da Lei da "Ficha Limpa" nas Eleições de 2010:

"AGRAVO REGIMENTAL. RECURSO ORDINÁRIO. REGISTRO DE CANDIDATURA. ELEIÇÕES 2010. DEPUTADO FEDERAL. INELEGIBILIDADE. ART. $1^{\circ}$, I, g, DA LEI COMPLEMENTAR $\mathrm{N}^{\circ}$ 64/90. IRREGULARIDADES INSANÁVEIS. ATOS DOLOSOS DE IMPROBIDADE ADMINISTRATIVA. NÃO PROVIMENTO.

1. O Tribunal Superior Eleitoral firmou o entendimento de que a Lei Complementar $n^{\circ} 135 / 2010$ é constitucional e se aplica às eleições de 2010.

2. A inelegibilidade do art. $1^{\circ}, I, g$, da Lei Complementar $n^{\circ} 64 / 90$ constitui uma consequência do fato objetivo da rejeição de contas públicas, não implicando retroatividade da lei ou violação à coisa julgada. Precedente.

3. As irregularidades constatadas pelo Tribunal de Contas do Estado do Paraná - despesas com subsídios de vereadores em percentual superior ao disposto no art. 29-A, I, da Constituição Federal e contratação de pessoal sem concurso público - são insanáveis e caracterizam, em

${ }^{438}$ AGUIAR, Afonso Gomes; AGUIAR, Márcio Paiva de. Op. cit. p. 19. 
tese, atos de improbidade administrativa (arts. 10, XI e 11, V, da Lei $\left.\mathrm{n}^{\circ} 8.429 / 92\right)$.

4. No caso, a decisão que rejeitou as contas do então Presidente da Câmara Municipal de Sapopema/PR, ora agravante, relativa ao exercício de 2001, foi julgada em 2004 e confirmada, em sede de recurso de revista, em 2008.

5. Agravo regimental não provido". ${ }^{439}$ (grifos nossos)

O caso em comento cuida de candidato que buscava o registro de sua candidatura a Deputado Federal nas Eleições de 2010, mas que teve seu pedido indeferido porque suas contas, enquanto Presidente da Câmara Municipal de Sapopema, no Paraná, foram rejeitadas pelo Tribunal de Contas do Estado, por irregularidades insanáveis, que configuravam, em tese, atos dolosos de improbidade administrativa, tornando-o inelegível em face da aplicação do artigo 1º, I, "g”, da Lei Complementar n 64/90 com a redação dada pela Lei Complementar no 135/10. Consoante ressaltou o Rel. Min. Aldir Passarinho Junior, em seu voto, os requisitos para a inelegibilidade prevista na Lei referida são: a) rejeição de contas, relativas ao exercício de cargo ou função pública, por irregularidade insanável que configure ato doloso de improbidade administrativa; b) decisão irrecorrível proferida pelo órgão competente; c) inexistência de provimento suspensivo ou anulatório emanado do Poder Judiciário. No caso concreto, as contas do Agravante foram rejeitadas pelo Tribunal de Contas do Estado do Paraná em razão das:

\begin{abstract}
“(...) despesas com subsídios de vereadores em percentual superior ao disposto no art. 29-A, I, da Constituição Federal e contratação de pessoal sem concurso público (fls. 47-53). A decisão que rejeitou as contas do agravante, relativa ao exercício de 2001, foi julgada em 2004 e confirmada, em sede de recurso de revista, em 2008. Nesse contexto, verifica-se que a rejeição das contas decorreu de falhas que não caracterizaram apenas impropriedades formais, mas sim irregularidades materiais graves e, portanto, insanáveis. Ademais as mencionadas irregularidades configuram, em tese, atos de improbidade administrativa, a teor dos arts. 10, XI e 11, V, da Lei n ${ }^{\circ} 8.429 / 92$, em razão dos prejuízos aos cofres públicos". 440
\end{abstract}

Além disso, as contas do então Presidente da Câmara Municipal foram julgadas pelo Tribunal de Contas do Estado do Paraná por ser este o órgão

\footnotetext{
${ }^{439}$ Agravo Regimental no Recurso Ordinário no 1614-41.2010.6.16.0000, Rel. Min. Aldir Passarinho Junior. Agravo regimental desprovido, por maioria. Publicado em sessão de 16/11/10. Disponível em: <http://www.tse.jus.br/jurisprudencia/inteiro-teor>, acesso em 03 de dez. 2011.

${ }^{440}$ Agravo Regimental no Recurso Ordinário no 1614-41.2010.6.16.0000, Rel. Min. Aldir Passarinho Junior. Agravo regimental desprovido, por maioria. Publicado em sessão de 16/11/10. p. 8. Disponível em: <http://www.tse.jus.br/jurisprudencia/inteiro-teor>, acesso em 03 de dez. 2011.
} 
competente, conforme dispõe o inciso II do artigo 71 da Constituição Federal. Julgadas, a decisão tornou-se irrecorrível na própria Corte e, ainda conforme ressaltou o Relator, não havia nos autos notícias de que o julgamento fora suspenso ou anulado pelo Poder Judiciário $^{441}$. Por todos estes motivos o Agravante teve a sua inelegibilidade decretada, não sendo deferido o registro de sua candidatura às Eleições de 2010.

Observa-se, portanto, a força que possui o julgamento proferido pelo Tribunal de Contas quando desaprova as contas de um administrador público que utiliza o dinheiro público: a rejeição é capaz de gerar a inelegibilidade do gestor, desde que, como se disse, tenha este praticado irregularidade insanável que configure ato doloso de improbidade administrativa, seja a decisão do Tribunal de Contas irrecorrível e não haja provimento do Poder Judiciário suspendendo ou anulando a decisão da Corte de Contas.

Analisada a competência para o julgamento das contas, abordamos, em seguida, o estudo das demais competências do Tribunal de Contas, mas apenas de forma genérica, por não serem objeto específico de nossa tese.

\footnotetext{
${ }^{441}$ Nada impede, no entanto, que o gestor público descontente recorra ao Poder Judiciário contra a decisão do Tribunal de Contas e consiga reverter a decisão em âmbito judicial. É o caso, por exemplo, de candidato às eleições de 2010 que teve suas contas rejeitadas pelo Tribunal de Contas ficando, pois, inelegível (artigo $1^{\circ}$, I, "g", da Lei Complementar $n^{\circ} 64 / 90$ ) e, por isso, o registro de sua candidatura foi indeferido. O candidato recorreu ao Tribunal Superior Eleitoral e obteve a concessão de medida liminar que suspendeu os efeitos da decisão de rejeição das contas pelo inciso II do artigo 71 da Constituição Federal. Com isso, o registro de sua candidatura pode ser realizado, já que a inelegibilidade fruto da rejeição das contas pelo Tribunal de Contas foi suspensa. Eis a ementa do Agravo Regimental em Recurso Ordinário no 396478 Fortaleza/Ceará: AGRAVO REGIMENTAL. RECURSO ORDINÁRIO. REGISTRO DE CANDIDATURA. ELEIÇÕES 2010. DEPUTADO FEDERAL. INELEGIBILIDADE. ART. $1^{\circ}$, I, g, DA LEI COMPLEMENTAR N 64/90. ANTECIPAÇÃO DE TUTELA POSTERIOR AO PEDIDO DE REGISTRO. FATO SUPERVENIENTE. NÃO PROVIMENTO. 1. Consoante recente jurisprudência do c. Tribunal Superior Eleitoral, o afastamento da inelegibilidade do art. $1^{\circ}$, I, g, da Lei Complementar $\mathrm{n}^{\circ}$ 64/90, com redação dada pela Lei Complementar $n^{\circ}$ 135/2010, pressupõe a obtenção de medida liminar ou de antecipação de tutela que suspenda os efeitos de decisão de rejeição de contas. 2. Nos termos do art. 11, § 10, da Lei $n^{\circ} 9.504 / 97$, a obtenção de liminar posterior ao pedido de registro constitui alteração superveniente apta a afastar a inelegibilidade decorrente da rejeição de contas. 3. Na espécie, o agravado obteve, em 4.8.2010, antecipação de tutela para suspender os efeitos da decisão do TCM/CE que rejeitou suas contas, razão pela qual não incide a causa de inelegibilidade prevista no mencionado dispositivo legal. 4. Agravo regimental não provido. O Tribunal, por unanimidade, desproveu o agravo regimental, nos termos do voto do Relator. Impedido o Ministro Henrique Neves. Agravo Regimental em Recurso Ordinário no 396478 Fortaleza/Ceará, Rel. Min. Aldir Guimarães Passarinho Júnior. Publicado em sessão de 07/10/2010. Disponível em <http://www.tse.jus.br/jurisprudencia/inteiro-teor>, acesso em 08 de jan. 2012. No mesmo sentido o Agravo Regimental em Recurso Ordinário no 415441 - Fortaleza/Ceará, Rel. Min. Aldir Guimarães Passarinho Júnior, acórdão publicado em sessão de 15/09/2010. Disponível em: <http://www.tse.jus.br/jurisprudencia/pesquisa-de-jurisprudencia/jurisprudencia>, acesso em 08 de jan. 2012.
} 


\subsubsection{As demais competências}

As demais competências do Tribunal de Contas estão elencadas nos incisos III a XI do artigo 71 da Constituição Federal.

A do inciso III refere-se à apreciação, para fins de registro, da legalidade dos atos de admissão de pessoal na administração direta e indireta, com exceção dos cargos de provimento em comissão. A Corte de Contas também analisa as concessões de aposentadorias, reformas e pensões. Nestas situações, se os atos e as concessões forem legais, o Tribunal lhes determinará o registro; se ilegais, fixará prazo para que a autoridade competente adote as providências necessárias à regularização do ato.

A competência prevista no inciso IV autoriza o Tribunal de Contas, por iniciativa própria, ou atendendo à solicitação da Câmara Municipal ou de Comissão Parlamentar de Inquérito, a realizar auditorias de natureza contábil, financeira, orçamentária, operacional e patrimonial, nas unidades administrativas dos Poderes Legislativo, Executivo e Judiciário ${ }^{442}$ e nas entidades da administração indireta municipal. As auditorias analisarão a legalidade e também a legitimidade, a economicidade, a aplicação de subvenções e renúncias de receitas relativas aos gastos realizados.

Outra competência (inciso V), em âmbito federal, diz respeito à fiscalização das contas nacionais de empresas, incluídas as supranacionais, de cujo capital social o Município participe, de forma direta ou indireta, nos termos do ato constitutivo ou de tratado. Como o Tribunal de Contas deve fiscalizar o uso do dinheiro público em empresas públicas, fundações governamentais e sociedades de economia mista, também deverá fiscalizá-lo quando se tratar de empresas supranacionais.

A competência do inciso VI permite o Tribunal de Contas fiscalize a aplicação de quaisquer recursos repassados pela União e Estados aos Municípios, mediante convênio, acordo ou ajuste ou outros instrumentos congêneres. Neste caso, exige-se que o gestor público - mesmo Prefeito - comprove o uso do dinheiro público nos

442 Ao Tribunal de Contas no âmbito dos Municípios de São Paulo e do Rio de Janeiro não compete a realização de auditoria no Poder Judiciário porque este inexiste no ente federativo municipal. 
instrumentos citados, demonstrando "a legalidade e a economicidade e a finalidade dos gastos públicos". ${ }^{443}$

O inciso VII determina ao Tribunal de Contas prestar as informações solicitadas pela Câmara ou pelas suas comissões, sobre assuntos de fiscalização contábil, financeira, orçamentária, operacional e patrimonial e sobre os resultados de auditorias e inspeções realizadas em órgãos do Executivo, Legislativo e Judiciário ou entidades da administração indireta. No que tange a esta matéria, pelo fato de, no âmbito municipal, com exceção dos Municípios de São Paulo e do Rio de Janeiro, existirem o Tribunal de Contas dos Municípios ou o Tribunal de Contas do Estado - ambos órgãos estaduais - permite-se que a Câmara Municipal solicite informações à Corte de Contas - órgão estadual - que deverá prestá-las à Câmara. Assim, nas palavras de José Nilo de Castro, "não há capitis diminutio alguma do Tribunal de Contas em atender referida solicitação, como poderia parecer ao menos avisados, quer do Tribunal - que acha que pode tutelar os Municípios -, quer de administradores municipais que se julguem subordinados àquele órgão de controle externo, quando não o são". 444

Conforme já comentado no item 4.4.3 (A ampliação da atividade fiscalizadora do Tribunal de Contas), o inciso VIII autoriza o Tribunal de Contas a aplicar aos responsáveis, em caso de ilegalidade de despesa ou irregularidade de contas, as sanções previstas em lei, que estabelecerá, entre outras cominações, multa proporcional ao dano causado ao erário. Dentre tais sanções estão as multas, a pena de advertência e, para a maioria dos Tribunais de Contas, à exceção do existente no Município de São Paulo, também as penas ${ }^{445}$ de inidoneidade do licitante fraudador, de impedimento ou suspensão do direito de participar de licitação na Administração Pública municipal, por até cinco anos e a inabilitação do responsável, pelo período de cinco a oito anos, para o exercício de cargo em comissão ou função de confiança na Administração Pública municipal.

O inciso IX permite ao Tribunal de Contas assinar prazo para que o órgão ou entidade adote as providências necessárias ao exato cumprimento da lei, se

${ }^{443}$ CASTRO, José Nilo de. Op. cit. p. 485.

${ }^{444}$ Idem. Ibidem.

445 Estas penas são da Lei $n^{\circ} 15.958$, de 18 de janeiro de 2007 (Lei Orgânica do Tribunal de Contas dos Municípios do Estado de Goiás) e estão dispostas no Capítulo VII - "Das Sanções e Medidas Cautelares. Mas há dispositivos semelhantes nas Leis Orgânicas dos Estados de Mato Grosso, Mato Grosso do Sul e Distrito Federal, por exemplo. Para detalhes, consultar: <http://www.tcm.go.gov.br/site/legislacao/indexLegislacao.jsf;jsessionid=03AA12F71918B1B27E621A282 C1D9B1C>, acesso em 12 de jan. 2012. 
verificada ilegalidade. É o que ocorre quando um ato de admissão de pessoal for tido pelo Tribunal de Contas como ilegal. Nesta hipótese, o Tribunal fixará prazo para que a Administração municipal cumpra a lei.

$\mathrm{O}$ inciso $\mathrm{X}$ autoriza o Tribunal de Contas a sustar, se não atendido, a execução do ato impugnado, comunicando a decisão à Câmara dos Vereadores. Nesta situação, verificado um ato ilegal, por exemplo, um edital de licitação com incorreções, pode o Tribunal de Contas fixar prazo para que o Secretário Municipal as corrija. Se o Secretário permanecer inerte e não alterar o instrumento convocatório, pode o Tribunal de Contas sustá-lo, comunicando, neste caso, à Câmara Municipal. Assim, se a suspensão for temporária não há necessidade de a Casa das Leis ser comunicada; se definitiva, sim. Neste último caso, a decisão tem que ser do Pleno e não de um Conselheiro de forma monocrática. Além disso, caso o Secretário não atenda à determinação do Tribunal de Contas, a única possibilidade é este aplicar multa ao Secretário e não imputar-lhe uma infração penal, que só é permitida ao Poder Judiciário. Neste caso, entendemos que o Tribunal pode comunicar ao Ministério Público a prática do ilícito, para adoção dos procedimentos cabíveis.

A única exceção à sustação definitiva de atos pelo Tribunal de Contas refere-se aos contratos. Para estes, há expressa previsão constitucional no $\S 1^{\text {o446 }}$ do artigo 71, determinando que a sustação compete à Câmara Municipal; entretanto, se nem esta e nem o Poder Executivo municipal tomarem as providências cabíveis no prazo de noventa dias, caberá ao Tribunal de Contas adotá-las, consoante dispõe o $§ 2^{\circ}$ do artigo 71 da Constituição Federal.

A competência do inciso XI diz respeito à possibilidade de o Tribunal de Contas representar ao Poder competente sobre irregularidades ou abusos apurados. Irregularidades, segundo Odete Medauar, são ilegalidades cometidas e abusos apurados coincidem com o abuso de poder $^{447}$. Em qualquer caso o Tribunal de Contas,

446 “Art. 71. (...) $\$ 1^{\circ}$. No caso de contrato, o ato de sustação será adotado diretamente pelo Congresso
Nacional que solicitará, de imediato, ao Poder Executivo as medidas cabíveis". BRASIL. Constituição
(1988). Constituição da República Federativa do Brasil: promulgada em 5 de outubro de 1988: atualizada
até a Emenda Constitucional n' 67, de 22-12-2010. $45^{\text {a }}$ ed. ampl. São Paulo: Saraiva, 2011. p. 70 .
447 Odete Medauar explica que os termos irregularidades e abusos são imprecisos e podem gerar dúvidas. Em
Direito Administrativo, assevera a autora, "abuso teria acepção de abuso de poder, que abrange o excesso e o
desvio de poder, incluídos entre as ilegalidades. Irregularidade apresenta-se como sinônimo de ilegalidade.
Na Constituição de 1969 dispositivo semelhante referia-se à representação ao Poder Executivo e ao
Congresso Nacional; o texto em vigor menciona 'poder competente'; parece claro que se trata de 
enquanto órgão de controle externo, pode comunicar ao Poder competente as irregularidades e abusos apurados.

As competências aqui mencionadas dizem respeito ao Tribunal de Contas da União e foram transpostas, em decorrência do princípio da simetria constitucional, para o âmbito municipal, no que couber. Em se tratando do Município de São Paulo, o artigo 48 da Lei Orgância do Município especifica as competências do Tribunal de Contas do Município, com as necessárias adaptações.

Examinadas as competências passamos à analise da composição do Tribunal de Contas no âmbito do Município.

\subsubsection{A sua composição}

Em relação à composição do Tribunal de Contas, há que se destacar que a Constituição Federal estabelece o regramento a ser seguido no âmbito municipal, isto é, pelos Tribunais de Contas dos Estados, pelos Tribunais ou Conselhos de Contas dos Municípios dos Estados de Goiás, Pará, Ceará e Bahia e pelo Tribunal de Contas do Município de São Paulo e do Rio de Janeiro.

Em comum, os nomeados ao cargo de Conselheiro devem ter: mais de trinta e cinco e menos de sessenta e cinco anos de idade; idoneidade moral e reputação ilibada; notórios conhecimentos jurídicos, contábeis, econômicos e financeiros ou de administração pública e mais de dez anos de exercício de função ou de atividade profissional que exija os conhecimentos mencionados no inciso III, tudo consoante incisos I a IV do $\S 1^{0448}$ do artigo 73 da Constituição Federal. Destes, os requisitos relacionados à idade e exercício profissional são objetivos e sobre eles não pairam dúvidas. Os demais são subjetivos, o que pode ensejar diversas interpretações acerca dos elementos necessários ao preenchimento dos cargos de Conselheiro da Corte de Contas.

representação ao poder dotado de atribuição legal para adotar providências a respeito, seja o Legislativo ou Executivo. A representação poderá ocorrer paralelamente a outras medidas tomadas pelo Tribunal". MEDAUAR, Odete. Controle da administração pública. São Paulo: Revista dos Tribunais, 1993. p. 123.

448 BRASIL. Constituição (1988). Constituição da República Federativa do Brasil: promulgada em 5 de outubro de 1988: atualizada até a Emenda Constitucional no 67, de 22-12-2010. 45a ed. ampl. São Paulo: Saraiva, 2011. p. 71. A Lei Orgânica do Município de São Paulo, por sua vez, repete a disposição da Constituição Federal no seu artigo 49, caput e incisos I a IV do seu parágrafo único. BRASIL. Lei Orgânica do Município de São Paulo: atualizada com a Emenda Constitucional no 28/2006. José Fernando Ferreira Brega (Org.). São Paulo: Páginas \& Letras Editora e Gráfica: Associação dos Procuradores do Município de São Paulo, 2006. p. 41. 
Além disso, o Tribunal de Contas, em âmbito municipal, é formado por Conselheiros, ao invés de Ministros ${ }^{449}$, estes assim denominados apenas na esfera federal. Ademais, é a Constituição Federal que estabelece os parâmetros para a escolha dos integrantes da Corte: um terço (dos nove existentes em âmbito federal) é indicado pelo Presidente da República, com a aprovação do Senado Federal, sendo dois alternadamente dentre auditores e membros do Ministério Público junto ao Tribunal, indicados em lista tríplice pelo Tribunal, segundo os critérios de antiguidade e merecimento; e dois terços pelo Congresso Nacional ( $\$ 2^{\circ}$ do artigo 73$)$.

Por simetria constitucional, os Tribunais de Contas dos Municípios dos Estados da Bahia ${ }^{450}$, do Ceará, do Pará e de Goiás, que são órgãos estaduais, assim como os Tribunais de Contas dos demais Estados da federação, à exceção dos Municípios de São Paulo e do Rio de Janeiro, têm suas composições previstas nas respectivas Constituições Estaduais ${ }^{451}$ sendo, ao todo, consoante disposição da Constituição Federal, sete os Conselheiros (artigo 75, parágrafo único) dessas Cortes de Contas.

Ressalte-se, ademais, que o Supremo Tribunal Federal, na Súmula $\mathrm{n}^{\circ}$ 653, já decidiu como se distribuem as vagas em âmbito estadual: "No Tribunal de Contas Estadual, composto por sete conselheiros, quatro devem ser escolhidos pela Assembleia Legislativa e três pelo Chefe do Poder Executivo Estadual cabendo a este indicar um dentre auditores e outro dentre membros do Ministério Público, e um terceiro

449 A Constituição Federal utiliza a expressão "Ministros" para designar os componentes do Tribunal de Contas da União (artigo 73) e “Conselheiros” para o âmbito estadual (artigo 75, parágrafo único).

${ }^{450}$ A Lei Complementar $n^{\circ} 006$, de 06 de dezembro de 1991, alterada pela Lei Complementar $n^{\circ} 14$, de 25 de abril de 1998, que trata da Lei Orgânica do Tribunal de Contas dos Municípios do Estado da Bahia e dá outras providências, determina, em seu artigo 10, que o Tribunal de Contas dos Municípios é integrado por 7 (sete) Conselheiros, escolhidos, após aprovação pela Assembleia Legislativa, na seguinte ordem: um terço dos Conselheiros são indicados pelo Governador do Estado, com a aprovação da Assembleia Legislativa, sendo um de sua livre escolha e os outros dois alternando entre auditores e membros do Ministério Público junto ao Tribunal, indicados em lista tríplice pelo Tribunal e segundo os critérios de antiguidade e merecimento e dois terços escolhidos pela Assembleia Legislativa. BRASIL. Lei Complementar $n^{\circ} 006$, de 06 de dezembro de 1991, alterada pela Lei Complementar $\mathrm{n}^{\circ} 14$, de 25 de abril de 1998. Trata da Lei Orgânica do Tribunal de Contas dos Municípios do Estado da Bahia e dá outras providências. Disponível em: < http://www.tcm.ba.gov.br/leiorg.shtml>, acesso em 17 de nov. 2011.

${ }^{451}$ A Lei Orgânica do Tribunal de Contas dos Municípios do Pará, por exemplo, determina, no seu artigo $9^{\circ}$ que: "Os Conselheiros do Tribunal de Contas dos Municípios serão nomeados de conformidade com a Constituição do Estado do Pará dentre os brasileiros que satisfaçam os seguintes requisitos: (...)" BRASÍLIA (BR). Lei Complementar n ${ }^{\circ}$ 25, de 25 de agosto de 1994. Dispõe sobre a Lei Orgânica do Tribunal de Contas dos Municípios do Pará e dá outras providências. Disponível em: < http://www.tcm.pa.gov.br/component/rokdownloads/downloads/leis/39-lei-organica-do-tcmpa-1994.html>, acesso em 17 de nov. 2011. 
a sua livre escolha" ${ }^{452}$, de modo que qualquer Constituição Estadual que contenha algo diverso do exposto é inconstitucional.

Quanto aos Municípios de São Paulo e do Rio de Janeiro, há que se destacar que são as Constituições Estaduais e as Leis Orgânicas destes entes que estabelecem o número de Conselheiros de cada Corte de Contas. O curioso é que, o Município de São Paulo, apesar de ser uma das mais populosas cidades do país, possui apenas cinco ${ }^{453}$ Conselheiros, enquanto que o Município do Rio de Janeiro possui sete ${ }^{454}$.

452

<http://www.stf.jus.br/portal/cms/verTexto.asp?servico=jurisprudenciaSumula\&pagina=sumula_601_700>, acesso em 17 de nov. 2011. Daí porque o inciso 1 do $§ 2^{\circ}$ do artigo 31 da Constituição do Estado de São Paulo foi declarado inconstitucional na Ação Direta de Inconstitucionalidade no 397-6, Rel. Min. Eros Grau. É que a Constituição Paulista estabelecia que uma das vagas indicadas pelo Governador seria preenchida por integrante da Fazenda Estadual, em detrimento da vaga destinada ao Ministério Público junto ao Tribunal. Eis o inciso questionado: " $\S 2^{\circ}$. Os Conselheiros do Tribunal serão escolhidos: 1 - dois, pelo Governador do Estado com aprovação da Assembleia Legislativa, alternadamente entre os substitutos de Conselheiros e membros da Procuradoria da Fazenda do Estado junto ao Tribunal, indicados por este, em lista tríplice, segundo critérios de antiguidade e merecimento". O Supremo Tribunal Federal entendeu que a Procuradoria da Fazenda do Estado não poderia substituir o Ministério Público junto ao Tribunal de Contas e, por isso, julgou inconstitucional o artigo mencionado e, por arrastamento, o inciso 3 do mesmo $\S 2^{\circ}$, que dispunha " 3 - o último, uma vez pelo Governador do Estado, e duas vezes pela Assembleia Legislativa, alternada e sucessivamente. Neste caso, o Ministro Relator invocou a Súmula n 653 que dispõe que "No Tribunal de Contas Estadual, composto por sete conselheiros, quatro devem ser escolhidos pela Assembleia Legislativa e três pelo Chefe do Poder Executivo Estadual cabendo a este indicar um dentre auditores e outro dentre membros do Ministério Público, e um terceiro a sua livre escolha”. Veja a ementa da Ação Direta de Inconstitucionalidade no 397-6: AÇÃO DIRETA DE INCONSTITUCIONALIDADE. ITEM "1" DO $\S 1^{\circ}$ DO ARTIGO 31 DA CONSTITUIÇÃO DO ESTADO DE SÃO PAULO. TRIBUNAL DE CONTAS. CONSELHEIRO. ESCOLHA, MEMBROS DA PROCURADORIA DA FAZENDA DO ESTADO, IMPOSSIBILIDADE. ENUNCIADO Nº 653 DA SÚMULA DESTA CORTE. 1. Nos termos do Enunciado $\mathrm{n}^{\circ}$. 653 da Súmula desta Corte, nos Tribunais de Contas Estaduais, compostos por sete Conselheiros, três deles serão escolhidos pelo Governador do Estado, cabendo-lhe indicar um entre auditores e outro entre membros do Ministério Público Especial, o terceiro sendo da sua livre escolha. Os demais são escolhidos pela Assembléia Legislativa. 2. Quanto aos dois primeiros, apenas os audotires e membros do Ministério Público junto ao Tribunal de contas podem figurar entre os possíveis Conselheiros. 3. Pedido de declaração de inconstitucionalidade julgado procedente". (ADI 397-6, Rel. Min. Eros Grau, v. u., julgado em 03/08/05 e publicado no Diário de Justiça de 09/12/05). Disponível em: <http://redir.stf.jus.br/paginadorpub/paginador.jsp?docTP=AC\&docID=266336>, acesso em 17 de nov. 2011.

${ }^{453}$ Dispõe o artigo 151 da Constituição do Estado de São Paulo: “O Tribunal de Contas do Município de São Paulo será composto por cinco Conselheiros e obedecerá, no que couber, aos princípios da Constituição Federal e desta Constituição". SÃO PAULO (SP). Constituição do Estado de São Paulo: anotada e atualizada até Emenda Constitucional $n^{\circ} 14$, de 12.03.2002. $2^{\text {a }}$ ed. rev., anotada e atual. São Paulo: Imprensa Oficial do Estado, 2002. p. 79. Por outro lado, o artigo 49 da Lei Orgânica do Município de São Paulo: “Art. 49. O Tribunal de Contas, órgão de auxílio da Câmara Municipal, integrado por 5 (cinco) conselheiros, tem sede no Município de São Paulo e quadro próprio de pessoal, exercendo as atribuições previstas na Constituição da República, no que couber, e nesta Lei, em todo o Município. BRASIL. Lei Orgânica do Município de São Paulo: atualizada com a Emenda Constitucional no 28/2006. José Fernando Ferreira Brega (Org.). São Paulo: Páginas \& Letras Editora e Gráfica: Associação dos Procuradores do Município de São Paulo, 2006. p. 41.

${ }^{454}$ Dispõe o artigo $3^{\circ}$ da Lei Orgânica do Município do Rio de Janeiro: “Art. $3^{\circ}$. O Tribunal se compõe de Corpo Deliberativo de 7 (sete) Conselheiros, da Presidência e dos Órgãos Auxiliares". BRASIL. Deliberação $\mathrm{n}^{\circ}$ 34, de 10 de março de 1983. Institui o Regimento Interno do Tribunal de Contas do Município do Rio de Janeiro. Disponível em <http://www.tcm.rj.gov.br/Noticia/Informa/RI2.pdf>, acesso em 17 de nov. 2011. 
Dos cinco, dois são escolhidos pelo Prefeito, com a aprovação da Câmara Municipal e três, pela Câmara Municipal ${ }^{455}$ (artigo 50 da Lei Orgânica do Município)

Ainda quanto à composição da Corte de Contas, o Supremo Tribunal Federal já decidiu, na Ação Direta de Inconstitucionalidade no 2.117-6/Distrito Federal, que os membros indicados pelo Poder Legislativo não precisam, necessariamente, ser parlamentares integrantes do Congresso Nacional e, por simetria, da Assembleia Legislativa ou da Câmara dos Vereadores. Confira-se parte do voto proferido pelo Relator, Ministro Maurício Corrêa, na Ação Direta de Inconstitucionalidade no 2.117-6/Distrito Federal:

\begin{abstract}
"De pronto, estou de acordo em que, com relação às vagas destinadas ao Poder Legislativo, como querem as informações, não precisam necessariamente ser elas preenchidas por parlamentares integrantes do Congresso Nacional, mas igualmente por outras pessoas, desde que cumpridas as exigências enumeradas no artigo $73, \S 1^{\circ}$ e seus incisos na Carta Federal, embora até agora, quanto sei, tenham elas sido ocupadas por deputados e senadores". 456
\end{abstract}

Questão interessante diz respeito ao preenchimento das vagas para Conselheiro. Tomemos como exemplo o Município de São Paulo: neste caso, deve-se proceder à escolha rotativa - duas vagas de indicação do Prefeito seguida de três vagas para a Câmara Municipal - ou observa-se a origem da vaga de cada um dos Conselheiros? Esta questão já foi decidida em sede de medida liminar, pelo Supremo Tribunal Federal, na Ação Direta de Inconstitucionalidade $n^{\circ}$ 2.117-6, de relatoria do Ministro Maurício Corrêa e que se aplica ao Município, por simetria. Entendeu o Ministro que a vaga vincula a indicação. Vale dizer, se um Conselheiro indicado pelo Prefeito se aposentar, é o Chefe do Executivo municipal que tem o direito de indicar o seu novo integrante, ainda que a Câmara Municipal pleiteie tal vaga em razão da rotatividade. Analisemos a ementa desta Ação Direta de Inconstitucionalidade:

\footnotetext{
${ }^{455}$ Dispõe o artigo 50, da Lei Orgânica do Município de São Paulo: “Art. 50. Os Conselheiros do Tribunal de Contas serão escolhidos obedecidas as seguintes condições: I - 2 (dois) pelo Prefeito, com aprovação da Câmara Municipal; II - 3 (três) pela Câmara Municipal". BRASIL. Lei Orgânica do Município de São Paulo: atualizada com a Emenda Constitucional no 28/2006. José Fernando Ferreira Brega (Org.). São Paulo: Páginas \& Letras Editora e Gráfica: Associação dos Procuradores do Município de São Paulo, 2006. p. 41.

${ }^{456}$ Ação Direta de Inconstitucionalidade $\mathrm{n}^{\circ}$ 2.117-6/Distrito Federal (Medida Liminar), Rel. Min. Maurício Corrêa. Tribunal Pleno do Supremo Tribunal Federal. Julgada em 03/05/00 e publicada no Diário de Justiça de 07/11/03. Disponível em: $<$ http://redir.stf.jus.br/paginadorpub/paginador.jsp?docTP=AC\&docID=347443>, acesso em 18 de nov. 2011.
} 
"TRIBUNAL DE CONTAS DA UNIÃO. COMPOSIÇÃO, VINCULAÇÃO DE VAGAS. INTELIGÊNCIA E APLICAÇÃO DO ARTIGO 73, § $2^{\circ}$, INCISOS I E II DA CONSTITUIÇÃO FEDERAL. DEFERIMENTO CAUTELAR.

1. O Tribunal de Contas da União é composto por 9 Ministros, sendo dois terços escolhidos pelo Congresso Nacional e um terço pelo Presidente da República (CF, artigo $73, \S 2^{\circ}$, incisos I e II). 1.2. O preenchimento de suas vagas obedece ao critério de origem de cada um dos Ministros, vinculando-se cada uma delas à respectiva categoria a que pertencem. 2. A Constituição Federal ao estabelecer indicação mista para a composição do Tribunal de Contas da União não autoriza adoção de regra distinta da que instituiu. Inteligência e aplicação do artigo $73, \S$ $2^{\circ}$, incisos I e II da Carta Federal. 3. Composição e escolha: inexistência de diferença conceitual entre os vocábulos, que traduzem, no contexto, o mesmo significado jurídico. 4. Suspensão da vigência do inciso III do artigo 105 da Lei $\mathrm{n}^{\circ} 8.443$, de 16 de julho de 1992, e do inciso III do artigo 280 do RITCU. Cautelar deferida". ${ }^{457}$ (grifos nossos)

Relembramos, no entanto, que a decisão foi proferida em sede de liminar sem que haja, ainda, o julgamento definitivo da ação.

Pensamos, a respeito, que o critério preserva o equilíbrio entre o Poder Executivo e o Poder Legislativo na Corte de Contas, ou seja, mantém a

${ }^{457}$ Ação Direta de Inconstitucionalidade $n^{\circ}$ 2.117-6/Distrito Federal (Medida Liminar), Rel. Min. Maurício
Corrêa. Tribunal Pleno do Supremo Tribunal Federal. Julgada em 03/05/00 e publicada no Diário de Justiça
de $\quad$ 07/11/03.

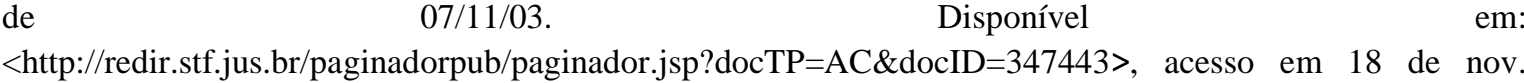
2011. Discutia-se, na ação em comento, a constitucionalidade do artigo 105 da Lei Orgânica do Tribunal de Contas da União, que prescrevia: "Art. 105. O processo de escolha de Ministro do Tribunal de Contas da União, em caso de vaga ocorrida ou que venha a ocorrer após a promulgação da Constituição de 1988, obedecerá ao seguinte critério: I - na primeira, quarta e sétima vagas, a escolha caberá ao Presidente da República, devendo recair as duas últimas, respectivamente, em auditor e membro do Ministério Público junto ao Tribunal; II - na segunda, terceira, quinta, sexta, oitava e nona vagas, a escolha será da competência do Congresso Nacional; III - a partir da décima vaga, reinicia-se o processo previsto nos incisos anteriores, observada a alternância quanto à escolha de auditor e membro do Ministério Público junto ao Tribunal, nos termos do inciso I do $\S 2^{\circ}$ do artigo 73 da Constituição Federal”. Em seu voto, o Relator, Ministro Maurício Corrêa proferiu: "26. A Constituição não contém expressões vazias, ocas, perdidas, sem significado, daí por que ao estabelecer o legislador Constituinte $\left(\mathrm{CF}\right.$, artigo $73, \S 2^{\circ}$, I e II) o modelo para o funcionamento do Tribunal de Contas, e nele fixado que a escolha se realiza com a presença de dois terços para o Congresso Nacional e de um para o Presidente da República, como a conceituou, fê-lo para que fosse respeitada a composição de modo permanente, e não sujeita a outras regras, a exemplo das consignadas nas disposições atacadas, que podem produzir as figurações que antes mencionei, fazendo com que a Corte possa julgar, desfalcada de sua real composição. 27. Se assim para mim é, com as vênias rogadas à iterada afirmativa do e. Presidente da Corte requerida, de que 'o Tribunal não possui uma composição constitucionalmente definida, mas apenas um critério rotativo de escolha', penso que, ao contrário, tem ele composição expressa na Carta Federal, segundo o sistema nela definido ( $\mathrm{CF}$, artigo $73, \S 2^{\circ}$, I e II), jamais podendo prevalecer, por isso mesmo, a escolha rotativa, que se possível, introduziria, aí sim, critério não autorizado pela Constituição". (grifos nossos) Ação Direta de Inconstitucionalidade n ${ }^{\circ}$ 2.117-6/Distrito Federal (Medida Liminar), Rel. Min. Maurício Corrêa. Tribunal Pleno do Supremo Tribunal Federal. Julgada em 03/05/00 e publicada no Diário de Justiça de 07/11/03. Disponível em: <http://redir.stf.jus.br/paginadorpub/paginador.jsp?docTP=AC\&docID=347443>, acesso em 18 de nov. 2011. 
proporcionalidade e alternância estabelecidas pelo Texto Constitucional, que distribui as vagas entre esses Poderes, evitando, por exemplo, que a vacância de cargos leve a uma composição exclusiva de Conselheiros (Ministros) indicados pela Câmara Municipal ou, ao contrário, pelo Prefeito.

Analisadas as características gerais da função de controle, a cargo do Poder Legislativo e do Tribunal de Contas, no próximo Capítulo estudaremos especificamente a competência para a aprovação das contas municipais, o que se faz através da participação do Tribunal de Contas, elaborando o parecer prévio - técnico e obrigatório - que aprecia as contas de governo anualmente prestadas pelo Prefeito e da participação da Câmara Municipal, julgando ditas contas. Compete-nos, então, trazer as especificidades da atuação de cada um - Tribunal de Contas e Câmara dos Vereadores - na aprovação das contas municipais. 


\section{CAPÍtUlo V: DA COMPETÊNCIA PARA A APROVAÇÃO DAS CONTAS MUNICIPAIS}

Após a análise das atribuições do Poder Legislativo municipal e do Tribunal de Contas no exercício da função de controle externo, bem como do exame, em linhas gerais, de como ocorre a apreciação e o julgamento das contas do Executivo passamos, neste Capítulo, ao estudo das competências de cada uma das Instituições Tribunal de Contas e Câmara dos Vereadores - na tarefa de aprovação das contas municipais.

A competência do Tribunal de Contas diz respeito à elaboração do parecer prévio, enquanto a da Câmara Municipal, ao seu julgamento. O primeiro constitui um exame técnico, o segundo, político.

Estudaremos, então, de forma específica, cada uma destas competências, começando pelas características do parecer prévio.

\subsection{A participação do Tribunal de Contas na função fiscalizadora das "contas de governo" anualmente prestadas pelo Prefeito: a apreciação das contas municipais através da elaboração do parecer prévio}

A competência mais importante do Tribunal de Contas consiste em, anualmente, apreciar as contas de governo do Prefeito, fazendo-o mediante a elaboração de um parecer prévio, que é encaminhado para o julgamento político na Câmara Municipal.

Iniciamos por definir o significado da palavra "apreciar”, referente à elaboração, pelo Tribunal de Contas, do parecer prévio.

O Dicionário Caldas Aulete define "apreciar" da seguinte forma: “1. Dar valor, apreço a; estimar. (...) 2. Observar com prazer; 3. Formar opinião sobre; considerar; avaliar. (...)". 458 
O Dicionário de Sinônimos e Antônimos da Língua Portuguesa, por sua vez, prevê como sinônimos de "apreciar": "estimar, prezar, considerar, admirar, amar. Avaliar, julgar, analisar, considerar, examinar: Apreciar a situação. Ver, assistir: Apreciar um espetáculo". 459

O sentido que importm, em nosso trabalho, é, portanto, o de “avaliar", "analisar", “examinar". Não o de "julgar” porque, como se estudará adiante, julgar traz a conotação de definitividade, característica que o parecer prévio não possui. Sobre o tema, profere José Cretella Júnior: “apreciar as contas não é julgar o responsável pelas contas: é fiscalizá-las, verificar se são boas ou más, é observar a aplicação correta dos dinheiros públicos". 460

Compete, pois, ao Tribunal de Contas, "avaliar", "analisar", "examinar" as contas municipais por meio das fiscalizações contábil, financeira, orçamentária, operacional e patrimonial e, então, apreciar as receitas, as despesas, o uso dos recursos públicos, elaborando o parecer prévio, peça técnica, que irá subsidiar o julgamento das contas municipais, a ser realizado na Câmara Municipal.

\subsubsection{O significado de "parecer prévio"}

Antes de adentrarmos nas características do parecer prévio, convém esclarecer o significado da expressão "parecer prévio".

Começamos pelo ensinamento de Maria Sylvia Zanella Di Pietro, que define o parecer como "o ato pelo qual os órgãos consultivos da Administração emitem opinião sobre assuntos técnicos ou jurídicos de sua competência". ${ }^{461}$

Hely Lopes Meirelles, por sua vez, explica que os pareceres administrativos consistem em "manifestações de órgãos técnicos sobre assuntos submetidos à sua consideração". ${ }^{462}$ Mais adiante, explana que o parecer técnico "é o que

\footnotetext{
${ }^{459}$ FERNANDES, Francisco. Op. cit. p. 94.

${ }^{460}$ CRETELLA JÚNIOR, José. Comentários à Constituição Brasileira de 1988. $2^{\mathrm{a}}$ ed. v. V (arts. 38 a 91). Rio de Janeiro: Forense Universitária, 1997. p. 2796.

${ }^{461}$ DI PIETRO, Maria Sylvia Zanella. Direito... Op. cit. p. 219.

${ }^{462}$ MEIRELLES, Hely Lopes. Direito administrativo... Op. cit. p. 193.
} 
provém de órgão ou agente especializado na matéria, não podendo ser contrariado por leigo ou, mesmo, por superior hierárquico". ${ }^{463}$

Parecer prévio, por seu turno, é definido por Antônio Carlos Doorgal de Andrada, Conselheiro do Tribunal de Contas do Estado de Minas Gerais e por Laura Correa de Barros como:

\begin{abstract}
"Assim, em termos mais particulares, o Parecer Prévio pode ser definido como um documento que contém a análise técnica e, a priori, formal, feita pelo Tribunal de Contas da União, por Tribunal de Contas Estadual ou por Tribunal de Contas dos Municípios sobre determinados aspectos das contas prestadas anualmente pelos chefes dos Poderes Executivos Federal, Estaduais ou Municipais, análise esta que orientará o Poder Legislativo no julgamento dessas contas". ${ }^{464}$
\end{abstract}

Prévio indica que o parecer do Tribunal de Contas, no âmbito do Município, deve ser elaborado antes do julgamento político feito pela Câmara dos Vereadores.

Das definições citadas, pode-se extrair que o parecer prévio é, de fato, uma peça técnica produzida por órgão - Tribunal de Contas - altamente especializado. Tal especialização, no caso da Corte de Contas, se refere aos aspectos contábeis, financeiros, orçamentários, operacionais e patrimoniais das contas anualmente prestadas pelo Chefe do Poder Executivo e que irão subsidiar o seu julgamento a ser realizado na Câmara dos Vereadores.

É documento importante, sem o qual não é possível julgar as contas do Prefeito.

Cabe-nos, então, analisar as características deste parecer prévio para entender em que consiste a atuação do Tribunal de Contas na apreciação das contas de governo do Prefeito.

\footnotetext{
${ }^{463}$ Idem. p. 194.

${ }^{464}$ ANDRADA, Antonio Carlos Doorgal; BARROS, Laura Correa de. O Parecer Prévio como instrumento de transparência, controle social e fortalecimento da cidadania. Revista do Tribunal de Contas do Estado de Minas Gerais. Ano XXVIII, v. 77, n. 4. Belo Horizonte: out./nov./dez, 2010. p. 52.
} 


\subsubsection{Características do parecer prévio}

\subsubsection{O parecer prévio é técnico}

Consoante já expusemos no item 3.3.5 (Controle técnico), ao Tribunal de Contas compete a realização do controle técnico. Consiste este na análise da matéria orçamentária, quer elaborando o parecer prévio das contas municipais, quer julgando as contas de um administrador público (incisos I e II do artigo 71 da Constituição Federal de 1988).

E o controle orçamentário envolve, também, como já exposto, os aspectos contábil $^{465}$, financeiro ${ }^{466}$, orçamentário stricto $\operatorname{sensu}^{467}$, operacional ${ }^{468} \mathrm{e}$ patrimonial $^{469}$.

Todas estas espécies de fiscalização são abordadas no parecer prévio, que examina as contas anualmente prestadas pelo Prefeito.

A título de exemplo, para comprovar o seu aspecto técnico, trazemos à colação parte do relatório e voto do parecer prévio das contas municipais da cidade do Rio de Janeiro, referente ao exercício de 2010:

"Com a receita prevista de ( $\mathrm{R} \$ 13.600 .179,00 \mathrm{mil})$, foi arrecadado um valor $12,8 \%$ maior, um desempenho superior ao do exercício anterior, quando houve, inclusive, uma insuficiência de arrecadação de 3,55\% dos

\footnotetext{
465 José Cretella Júnior ensina que "um estudo geral de contabilidade pública deve levar em conta somente os pormenores técnicos para precisar o campo e a extensão desse poder de execução, bem como para mostrar como a autorização orçamentária se resolve na realidade das despesas e das receitas do Estado". CRETELLA JÚNIOR, José. Op. cit. p. 2783.

466 José Cretella Júnior assevera que o direito financeiro "tem por objeto o estudo sistemático das normas que regulam a arrecadação, a gestão e a distribuição dos meios econômicos pertencentes ao Estado e às demais entidades públicas, assim como o estudo das relações jurídicas que se formam entre os poderes e órgãos do Estado e os cidadãos, e até entre os próprios cidadãos, derivadas da aplicação dessas normas”. Idem. pp. 2783-2784.

${ }^{467}$ A fiscalização orçamentária, consoante José Cretella Júnior, está inserida na fiscalização financeira, que é mais genérica. A fiscalização do orçamento consiste na "previsão da receita e a fixação da despesa para determinado período financeiro. É o plano de conjunto das necessidades monetárias do Estado para certo período, discutido e aprovado publicamente pelos órgãos colegiados de representação popular. Idem. p. 2785. ${ }^{468}$ A fiscalização operacional, por seu turno, "concerne à execução orçamentária, isto é, ao cumprimento do projeto estabelecido no orçamento entre previsões de receitas e despesas e sua real obtenção e aplicação". BASTOS, Celso Ribeiro; MARTINS, Ives Gandra. Op. cit. p. 4.

${ }^{469}$ José Cretella Júnior, quanto ao patrimônio da União, destaca que ele abrange "o conjunto de todos os seus bens públicos, exceto os de uso comum do povo e os de uso especial, bens que servem, regra geral, como instrumento para que essa pessoa jurídica pública satisfaça os próprios fins, direta ou indiretamente, afetando-os às necessidades públicas ou aos serviços públicos federais, no primeiro caso, sem fito de lucro, no segundo com o intuito de gerar lucro”. CRETELLA JÚNIOR, José. Op. cit. p. 2786.
} 
recursos. A despesa realizada correspondeu a $87,62 \%$ da dotação final do exercício de 2010, praticamente o mesmo índice de 2009, quando apurou $87,37 \%$ de realização. As Receitas Correntes estão em processo de crescimento real tendo apresentado um crescimento nominal de $20 \%$ entre 2009 e 2010. (...) A Emenda Constitucional no 29 estabeleceu para os Municípios o percentual mínimo de $15 \%$ para aplicação em Ações e Serviços Públicos de Saúde, tendo o Município aplicado o percentual de $17,07 \%$ (...) E, finalmente, que com relação à execução orçamentária dos precatórios, foram realizados $51,07 \%$ do previsto, tendo sido efetivamente pagos $99,97 \%$ do total realizado. (...) VOTO pela emissão de Parecer Prévio FAVORÁVEL à presente Prestação de Contas do Exercício de 2010 com as recomendações, alertas e sugestões opinadas pela CAD". ${ }^{470}$

E o parecer prévio assim fixou:

"O Tribunal de Contas do Município do Rio de Janeiro, (...) e CONSIDERANDO que as contas do Poder Executivo, referentes ao exercício de 2010, foram prestadas dentro do prazo previsto no art. 107, inciso XII, da Lei Orgânica do Município do Rio de Janeiro; CONSIDERANDO que os balanços Orçamentário, Financeiro e Patrimonial e os Demonstrativos das Variações Patrimoniais estão escriturados conforme os preceitos de contabilidade pública e expressam os resultados da gestão orçamentária, financeira e patrimonial; CONSIDERANDO que as recomendações, ressalvas e alertas constantes dos pareceres vindos aos autos não prejudicam a exatidão das presentes contas; CONSIDERANDO que as análises do Corpo Instrutivo e da Procuradoria Especial concluem pela emissão de parecer prévio favorável; CONSIDERANDO, finalmente, que ficam pendentes de quitação as responsabilidades de administradores e demais responsáveis pela ordenação de despesas cujas Contas pendem de julgamento por este Tribunal RESOLVE emitir parecer prévio favorável à aprovação das Contas de Gestão da Prefeitura do Município do Rio de Janeiro, atinentes ao exercício de 2010, de responsabilidade do Prefeito, Eduardo da Costa Paes, sem prejuízo de que sejam consignadas as recomendações, alertas e sugestões a seguir especificados: (...)". ${ }^{471}$ (grifos nossos)

De igual sorte, o relatório do Conselheiro Antonio Carlos Caruso acerca das despesas e receitas referentes ao Município de São Paulo, no exercício de 2010, assim expôs:

\footnotetext{
${ }^{470}$ Parecer Prévio à prestação de Contas da Prefeitura da Cidade do Rio de Janeiro: exercício de 2010. Tribunal de Contas do Rio de Janeiro. Rel. Conselheiro Nestor Guimarães Martins da Rocha, julgado em 11 de julho de 2011. Rio de Janeiro: TCM-RJ, 2011. pp. 150-157.

471 Parecer Prévio à prestação de Contas da Prefeitura da Cidade do Rio de Janeiro: exercício de 2010. Tribunal de Contas do Rio de Janeiro. Rel. Conselheiro Nestor Guimarães Martins da Rocha, julgado em 11 de julho de 2011. Rio de Janeiro: TCM-RJ, 2011. p. 160.
} 
O orçamento consolidado para 2010, originalmente aprovado em $\mathrm{R} \$ 27,9$ bilhões, foi acrescido de $\mathrm{R} \$ 1,4$ bilhão por conta de créditos adicionais abertos com recursos do superávit financeiro de 2009 (R \$ 86,4 milhões) e do excesso de arrecadação ( $\mathrm{R}$ 1,3 bilhão). (...)

No exercício de 2010 foram arrecadados $\mathrm{R} \$ 28,1$ bilhões, que representou $8,8 \%$ a mais que o previsto, $\mathrm{R} \$ 25,8$ bilhões. Esse excesso de arrecadação da ordem de $\mathrm{R} \$ 2,3$ bilhões decorreu principalmente das Receitas de Capital. Nas receitas de capital houve excesso de arrecadação de R \$ 1,5 bilhão, Num total arrecadado de R \$ 2,7 bilhões. Contribuíram para isso: 1) as operações urbanas, que somadas, apresentaram $\mathrm{R} \$ 1,1$ bilhão de arrecadação, e 2) a alienação de bens móveis, não previstas no Orçamento, referente aos recursos provenientes do contrato com o Banco do Brasil, R\$ 726 milhões.

As despesas da Prefeitura em 2010 totalizaram R\$ 26,9 bilhões, aumentando $15,9 \%$ com relação ao exercício de 2009. A maior parte das despesas está concentrada em oito funções de governo, correspondentes a 88,6\% do total gasto em 2010: Educação - 23\%; Saúde - 19,3\%; Encargos Especiais - 12,7\%; Previdência Social - 9,3\%; Urbanismo 9,1\%; Transporte - 8,9\%; Habitação - 3,6\%; Assistência Social - 2,7\%; Demais Funções - 11,4\%". ${ }^{472}$

E, no voto, trazendo como exemplo os aspectos técnicos

observados na área da saúde, o Sr. Conselheiro Relator assim se pronunciou:

Também para a FUNÇÃO SAÚDE existe um limite mínimo de aplicação, disposto pela Emenda constitucional n ${ }^{\circ}$ 29/00, que é de $15 \%$ da receita dos impostos arrecadados.

As receitas que constituíram as bases de cálculo para a aplicação desse índice atingiram o valor de $\mathrm{R} \$ 20,88$ bilhões (vinte bilhões e oitenta e oito milhões de reais), em 2010.

O cálculo para obtenção do citado percentual utilizou os valores empenhados para essa função.

Ainda que essa forma de cálculo não atenda ao disposto pela Portaria $\mathrm{n}^{\circ}$ 2047 do Ministério da Saúde, que determina sua obtenção pelas Despesas Liquidadas, como salientam os nossos Auditores, a forma utilizada não implicou em prática de ilegalidade, posto que, se adotada a alternativa (que é a correta) de referência das Despesas Liquidadas, o índice mínimo também seria atendido, visto que ele somou $18,56 \%$ (dezoito ponto cinqüenta e seis por cento).

De qualquer forma, cabe determinação à Secretaria da Saúde, que, aliás, consistirá uma reiteração.

Foi também apontada a não operacionalização do Fundo Municipal de Saúde, cuja falta, aliás, é causa de uma AÇÃO PÚBLICA contra a Prefeitura. (...)

Dando por encerradas as questões que entendi necessário destacar e privilegiar, emito meu VOTO pela produção de PARECER FAVORÁVEL À APROVAÇÃO DAS CONTAS DO EXECUTIVO

${ }^{472}$ Balanço Geral ao Exercício de 2010, Prefeito Gilberto Kassab. Parecer Prévio nos autos do TC n 72.000.923.11-24, Rel. Conselheiro Antonio Carlos Caruso. Julgado em 28 de junho de 2011. v.u. favorável à aprovação das contas do Executivo. Votação unânime pela aprovação do parecer prévio favorável. 
referentes ao exercício 2010, com todas as propostas e determinações que se seguem e com exclusão das matérias ainda não apreciadas, que continuam pendentes de apreciação e julgamento.

É o meu voto". ${ }^{473}$

Fácil constatar que a análise do Tribunal de Contas, por ser realizada sobre a gestão orçamentária (o que engloba as fiscalizações contábil, financeira, orçamentária stricto sensu, operacional e patrimonial) é técnica e, pois, jurídica. Trata-se de parecer prévio sobre a receita e a despesa, sobre o ativo e o passivo, sobre o montante de dinheiro arrecadado e a forma como ele foi gasto ou empregado durante todo o ano.

\subsubsection{O parecer prévio é obrigatório}

Outra característica do parecer prévio é que ele é peça obrigatória. Quer isto dizer que não existe faculdade para o Tribunal de Contas de apreciar ou não as contas de governo do Prefeito. Deve fazê-lo e isto por disposição constitucional. Somente após analisadas pelo Tribunal de Contas é que as contas são submetidas a julgamento da Câmara Municipal.

Nos dizeres de Maria Carolina Barros Carvalho Fugagnoli, "o Poder Legislativo só poderá realizar seu julgamento após o pronunciamento do Tribunal de Contas que se formaliza no parecer prévio. É peça de caráter obrigatório, (...)". ${ }^{474}$

Maria Sylvia Zanella Di Pietro, citando obra de Oswaldo Aranha Bandeira de Mello, diferencia os pareceres facultativo, obrigatório e vinculante. Explica a autora que é "facultativo" o parecer que "fica a critério da Administração solicitá-lo ou não, além de não ser vinculante para quem o solicitou". 475 "Obrigatório" é o parecer que não pode deixar de ser emitido ou, nas palavras da autora, "quando a lei o exige como

473 Balanço Geral ao Exercício de 2010, Prefeito Gilberto Kassab. Parecer Prévio nos autos do TC n⿳⺈ 72.000.923.11-24, Rel. Conselheiro Antonio Carlos Caruso. Julgado em 28 de junho de 2011. v.u. favorável à aprovação das contas do Executivo. Votação unânime pela aprovação do parecer prévio favorável.

${ }^{474}$ FUGAGNOLI, Maria Carolina Barros Carvalho. Da competência do Tribunal de Contas para julgar as contas do Prefeito ordenador de despesas: uma análise do artigo 71, incisos I e II da Constituição Federal, aplicado simetricamente no âmbito municipal. Revista da ESMAPE. v. 12, n. 25. Recife: [s.n], jan./jun. 2007. p. 901.

${ }^{475}$ MELLO, Oswaldo Aranha Bandeira de. Princípios gerais de direito administrativo. v. 2. Rio de Janeiro: Forense, 1979. p. 575. Apud DI PIETRO, Maria Sylvia Zanella. Direito administrativo. $21^{\text {a }}$ ed. São Paulo: Atlas, 2008. p. 219. 
pressuposto para a prática do ato final" ${ }^{476}$ Por sua vez, o parecer é "vinculante" "quando a Administração é obrigada a solicitá-lo e a acatar a sua conclusão". ${ }^{477}$

À vista destes conceitos, pode-se concluir ser obrigatória e não vinculante a elaboração do parecer prévio pelo Tribunal de Contas, na medida em que o citado documento deve ser elaborado pelo Tribunal, mas não tem o condão de obrigar o Poder Legislativo municipal a acatar as decisões proferidas em sede de parecer prévio.

Ressalte-se, ademais, que o Prefeito tem o dever de encaminhar suas contas ao Tribunal de Contas em até sessenta dias após a abertura da sessão legislativa ${ }^{478}$ que, no Município de São Paulo inicia-se no dia 01 de fevereiro. O prazo final para o Prefeito do Município de São Paulo encaminhar suas contas é, pois, o dia 31 (trinta e um) de março.

Apresentado o Balanço pelo Prefeito, começa a viger o prazo para o Tribunal de Contas apreciá-lo. A Constituição Federal estabelece sessenta ${ }^{479}$ dias de prazo, contados de seu recebimento, para que o Tribunal de Contas produza a peça técnica. No Município de São Paulo, no entanto, esse prazo é de noventa ${ }^{480}$ dias, contados da data de seu recebimento, que tem como termo final o dia 31 (trinta e um) de março. Significa, então, que o Tribunal de Contas do Município de São Paulo deve apreciar as contas de governo do Prefeito, emitindo o parecer prévio, até o dia 30 (trinta) de junho de cada ano e,

\footnotetext{
${ }^{476}$ De acordo com a autora, o parecer é obrigatório no caso de "uma lei que exija parecer jurídico sobre todos os recursos encaminhados ao Chefe do Executivo; embora haja obrigatoriedade de ser emitido o parecer sob pena de ilegalidade do ato final, ele não perde o seu caráter opinativo. Mas a autoridade que não o acolher deverá motivar a sua decisão". Idem. Ibidem.

${ }^{477}$ A autora cita como exemplo os casos de concessão de aposentaria por invalidez, em que a Administração necessita ouvir o perito e não pode decidir contrariamente ao que o profissional determinou. Idem. Ibidem.

${ }^{478}$ No Município de São Paulo a sessão legislativa inicia-se no dia 01 (primeiro) de fevereiro. Assim, o Prefeito deve encaminhar suas contas até o dia 31 (trinta e um) de março e o Tribunal de Contas poderá analisá-las em até noventa dias, isto é, até o dia 30 (trinta) de junho encaminhando, posteriormente, o parecer prévio, para o julgamento da Câmara Municipal.

479 É o que determina o artigo 71, I, da Constituição Federal: “Art. 71. O controle externo, a cargo do Congresso Nacional, será exercido com o auxílio do Tribunal de Contas da União, ao qual compete: I apreciar as contas prestadas anualmente pelo Presidente da República, mediante parecer prévio que deverá ser elaborado em sessenta dias a contar de seu recebimento". BRASIL. Constituição (1988). Constituição da República Federativa do Brasil: promulgada em 5 de outubro de 1988: atualizada até a Emenda Constitucional no 67, de 22-12-2010. $45^{\mathrm{a}}$ ed. ampl. São Paulo: Saraiva, 2011. p. 69.

${ }^{480}$ É o que dispõe o artigo 48, I da Lei Orgânica do Município de São Paulo: "Art. 48. O controle externo, a cargo da Câmara Municipal, será exercido com o auxílio do Tribunal de Contas do Município de São Paulo, ao qual compete: I - apreciar as contas prestadas anualmente pelo Prefeito, (...) mediante parecer prévio que deverá ser elaborado em 90 (noventa) dias, a contar da data de seu recebimento, que terá seu terno final em 31 de março de cada exercício". BRASIL. Lei Orgânica do Município de São Paulo: atualizada com a Emenda Constitucional $n^{\circ}$ 28/2006. José Fernando Ferreira Brega (Org.). São Paulo: Páginas \& Letras Editora e Gráfica: Associação dos Procuradores do Município de São Paulo, 2006. p. 37.
} 
após, enviar o referido parecer para o julgamento político pela Câmara Municipal, que não tem, diferentemente do Chefe do Executivo e do Tribunal de Contas, prazo determinado para fazê-lo.

Dessa forma, a obrigatoriedade da elaboração do parecer prévio pelo Tribunal de Contas é uma resposta ao direito público subjetivo que tem o Prefeito de ver as suas contas julgadas. Sobre o tema, leciona José Nilo de Castro:

\begin{abstract}
"Inegavelmente, possuindo o prestador de contas públicas o dever de prestá-las na forma e prazo legais, socorre-lhes, igualmente, o direito público subjetivo de ter a emissão do parecer prévio, no prazo estabelecido, o que poderá buscar via judicial. À obrigação de o Tribunal emitir o parecer prévio, no prazo legal, corresponde o direito de sua emissão, no prazo, do Prefeito, prestador de contas". ${ }^{481}$
\end{abstract}

Entretanto, é preciso esclarecer que muitos Tribunais de Contas não conseguem cumprir o mister constitucional e apreciar as contas de governo municipais no prazo de sessenta dias ${ }^{482}$, seja por acúmulo de serviço ou por falta de pessoal qualificado. Ademais, trata-se de norma sem sanção.

Destacamos, no entanto, que o Prefeito, por ser detentor do direito público subjetivo de ter suas contas apreciadas pelo Tribunal de Contas, mediante a elaboração do parecer prévio, para, em seguida, serem julgadas pela Câmara Municipal pode, diante de eventual inércia do Tribunal de Contas na elaboração do parecer prévio, recorrer ao Poder Judiciário para ter o seu direito assegurado.

\title{
5.1.2.3. O parecer prévio é meramente opinativo?
}

Dos meandros que permeiam o parecer prévio, este é, talvez, o de resposta mais difícil e controversa.

\footnotetext{
${ }^{481}$ CASTRO, José Nilo de. Op. cit. p. 483.

482 José Nilo de Castro é quem esclarece: "Seja por volume de serviços, seja por insuficiência de pessoal qualificado, as Cortes de Contas não têm cumprido, ou não conseguem, ainda, cumprir sua missão constitucional no prazo previsto. É indiscutivelmente norma sem sanção, como também, no Judiciário por razões várias não se cumprem os prazos, na forma estabelecida em lei, uma das causas de morosidade da Justiça”. Idem. Ibidem.
} 
Alguns autores, ao cuidarem das funções do Tribunal de Contas, defendem que a elaboração do parecer prévio se insere na função de consulta. São eles Maria Sylvia Zanella Di Pietro ${ }^{483}$ e Jair Lima Santos ${ }^{484}$, por exemplo.

Hamilton Fernando Castardo tem posicionamento semelhante, porém, não idêntico. Para o autor, a função consultiva é observada quando o Tribunal de Contas elabora o parecer prévio que irá subsidiar o julgamento pela Câmara Municipal. No entanto, também se insere nesta função "decidir sobre consulta que lhe seja formulada por autoridade competente a respeito de dúvida suscitada quanto à aplicação de dispositivos legais e regulamentares concernentes à matéria de sua competência". ${ }^{485}$ Vislumbra, então, o autor, duas atribuições na função de consulta: a de elaborar o parecer prévio e a de dirimir dúvidas quanto à aplicação de dispositivos relativos a matéria de competência da autoridade administrativa. Em ambas há a atuação do Tribunal de Contas. Na primeira, elaborando o parecer prévio, que será julgado na Câmara Municipal e, na segunda, esclarecendo a dúvida lançada pelo administrador público.

Para entender em que consiste a função de consulta é preciso saber o significado do vocábulo "consultar". De acordo com o Dicionário Melhoramentos significa: "1. pedir conselho, instruções, opinião ou parecer a; 2 . sondar ou examinar antes de decidir; 3. procurar em livros esclarecimentos, ou opiniões de peritos sobre determinado assunto; 4. apresentar ou dar a sua consulta ou parecer sobre (algum assunto)"." 486

No caso em análise, "consultar" significa solicitar à autoridade competente - o Tribunal de Contas - uma opinião técnica sobre determinado assunto.

${ }^{483}$ A função de consulta do Tribunal de Contas inserta dentre as atividades de controle externo ocorre, consoante a autora, "quando emite parecer prévio sobre as contas prestadas anualmente pelo Presidente da República”. DI PIETRO, Maria Sylvia Zanella. Direito... Op. cit. p. 707. A autora classifica, ainda, as funções do Tribunal de Contas como de: fiscalização financeira propriamente dita, de consulta, de informação, de julgamento, sancionatórias, corretivas e de ouvidor. Para detalhes consultar: DI PIETRO, Maria Sylvia Zanella. Direito administrativo. 21 a ed. São Paulo: Atlas, 2008. pp. 707-708.

${ }^{484} \mathrm{O}$ autor explica que a função consultiva "se manifesta na apreciação das contas prestadas anualmente pleo Presidente da República e na conseqüente emissão de parecer prévio, a ser elaborado em sessenta dias a contar de seu recebimento, conforme dispõe o art. 71, I, da CF. Neste caso, a atuação do TCU se exaure com a emissão do parecer sobre as contas e relatórios de execução dos planos de governo, os quais serão, posteriormente, submetidos a julgamento perante o Poder Legislativo, na forma do art. 49, inc. IX, da CF”. SANTOS, Jair Lima. Tribunal de Contas da União \& controles estatal e social da administração pública. $1^{\mathrm{a}}$ ed. $4^{\text {a }}$ tiragem. Curitiba: Juruá, 2006. p. 75. Para este autor, as funções do Tribunal de Contas se dividem em: consultiva, judicante, fiscalizadora, informativa, sancionadora, corretiva, normativa e de ouvidoria. Para detalhes consultar: SANTOS, Jair Lima. Tribunal de Contas da União \& controles estatal e social da administração pública. $1^{\mathrm{a}}$ ed. $4^{\mathrm{a}}$ tiragem. Curitiba: Juruá, 2006. pp. 73-77.

${ }^{485}$ CASTARDO, Hamilton Fernando. Op. cit. p. 85.

486 DICIONÁRIO Melhoramentos da Língua Portuguesa. Antônio Houaiss (apresentação). São Paulo: Melhoramentos, 1994. p. 258. 
Assim, é possível, por exemplo, que o Prefeito consulte o Tribunal de Contas acerca da obrigatoriedade ou não de prorrogar um concurso público já realizado há dois anos, por pretender realizar uma nova seleção.

Jorge Ulisses Jacoby Fernandes esclarece a importância da consulta feita ao órgão técnico: “em termos de eficiência da Administração Pública, nada melhor para aqueles que lidam com finanças públicas do que ter previamente a interpretação do órgão de controle externo. Para esses, a ação preventiva resultante tem mais largo alcance, porque o controle orientador é muito mais eficiente do que o repressivo". ${ }^{487}$

É por associar o parecer prévio à função de consulta que alguns autores defendem que se trata de um documento que é meramente opinativo. Sustentam este posicionamento Ives Gandra Martins, Fernando Augusto Mello Guimarães e Maria Carolina Barros Carvalho Fugagnoli.

Ives Gandra Martins é categórico:

"A função do Tribunal de Contas, no que concerne a contas presidenciais, é, todavia, meramente opinativa. Apesar de seu exame ser apenas técnico, tal parecer não possui qualquer força sem o Congresso Nacional, que, no mais das vezes, julgará política e não tecnicamente o Presidente". ${ }^{488}$ (grifos nossos)

Exemplifica o autor o ocorrido com o caso do então Presidente Fernando Collor de Mello. Assevera que as contas de governo do Presidente foram aprovadas pelo Tribunal de Contas, porém, ao ser julgado, em processo de impeachment, por enriquecimento ilícito, perante a Câmara dos Deputados, sem que lhe tivesse sido assegurado o direito à ampla defesa, foi condenado e perdeu o mandato ${ }^{489}$. E conclui:

${ }^{487}$ FERNANDES, Jorge Ulisses Jacoby. Tribunais de Contas do Brasil: jurisdição e competência. $2^{\mathrm{a}}$ ed. Belo Horizonte: Fórum, 2005. p. 337.

${ }^{488}$ BASTOS, Celso Ribeiro; MARTINS, Ives Gandra. Op. cit. p. 21.

${ }^{489}$ Ives Gandra Martins explica a passagem: "O julgamento do Presidente Collor foi típico, visto que perdeu o mandato, na suspensão pela Câmara, tendo-lhe sido negado o direito de defesa e acesso aos documentos de acusação, com aval do Supremo Tribunal Federal, que decidiu contra a jurisprudência vigente, exceção feita a três votos, entre os quais se destaca o excepcional voto do Ministro José Carlos Moreira Alves, o qual, juridicamente, ofertava-lhe o direito de defesa e acesso aos documentos de acusação antes da suspensão, negado pela Corte Maior. No caso, é de se lembrar que todas as contas do Presidente da República tinham sido aprovadas tecnicamente pelo Tribunal de Contas, e a CPI, que recebeu o aval do Supremo Tribunal Federal, fora instaurada em relação a pessoa que não era do governo. Não fora instaurada para verificar a inidoneidade do Presidente da República, não tendo, até o momento em que faço estes comentários, sido 
"Tais fatos do passado que trago para este comentário são para demonstrar que o parecer técnico é de pouco valor, muito valor tendo a decisão política do Congresso, o qual poderá condenar contra o parecer de regularidade das contas emitido pelo Tribunal de Contas ou absolver contra a condenação técnica da Corte". ${ }^{490}$ (grifos nossos)

Fernando Augusto Mello Guimarães, por sua vez, também defende a natureza opinativa do parecer prévio. Explicita o autor:

"Não resta dúvida, que a competência atribuída às Cortes de Contas para emissão do parecer prévio das contas apresentadas pelo Poder Executivo, é meramente opinativa, quando recomenda a desaprovação ou aprovação das respectivas contas. A palavra final pertence ao Poder Legislativo competente. É conclusão indiscutível e reafirmada por todos que se detiveram no exame da natureza jurídica da manifestação do parecer prévio pelos Tribunais de Contas". ${ }^{491}$ (grifos nossos)

O autor precitado compara duas competências do Tribunal de Contas: a emissão do parecer prévio - que segundo ele é meramente opinativo -, com o julgamento das contas do Poder Legislativo que, neste caso, nada tem de opinativo, já que assume a condição de efetivo julgamento.

Maria Carolina Barros Carvalho Fugagnoli, por sua vez, cuida de explicar o sentido da expressão "auxiliar" que o Tribunal de Contas detém em relação ao Poder Legislativo quando aprecia as contas de governo do Prefeito: trata-se da elaboração de um parecer prévio que é meramente opinativo enquanto o julgamento político é realizado pela Câmara Municipal. Assevera a autora:

"Em se tratando das contas do chefe do Poder Executivo, o Tribunal de
Contas emite parecer de caráter meramente opinativo e o Poder
Legislativo julgá-las-á, proferindo sua decisão independentemente
daquilo estabelecido no parecer. Trata-se de julgamento político. O
relatório, como peça técnica, não obriga o Parlamento. Ele constitui
uma análise sobre a execução financeira e orçamentária do
respectivo exercício e que servirá de apoio ao Legislativo. Daí o uso

estabelecido sequer um nexo causal entre a atuação do Sr. PC Farias e o enriquecimento ilícito do Presidente da República ou autorização deste para que aquele cidadão agisse em seu nome”. Idem. Ibidem.

${ }^{490}$ Idem. p. 22.

491 GUIMARÃES, Fernando Augusto Mello. Julgamento das contas anuais pelo Tribunal de Contas (aspectos controvertidos). Revista do Tribunal de Contas do Estado do Paraná. n. 117. Curitiba: jan./mar., 1996. p. 79. 
feito pelo Constituinte originário da expressão 'auxiliar"." ${ }^{492}$ (grifos nossos)

Adverte a autora, no entanto, que a situação é diferente no âmbito municipal, o que será estudado em seguida, quando tratarmos dos posicionamentos que defendem que o parecer prévio não é meramente opinativo.

Destaca-se, ainda, o entendimento do Supremo Tribunal Federal em julgamento da Ação Direta de Inconstitucionalidade no ${ }^{\circ} 49-8 /$ Mato Grosso, em que se discutia a constitucionalidade do inciso $\mathrm{I}^{493}$ do artigo 47 da Constituição do Estado do Mato Grosso, com a redação dada pela Emenda Constitucional n ${ }^{\circ}$ 01/91, que determinou que as contas da Mesa da Assembleia Legislativa seriam apreciadas por parecer prévio de lavra do Tribunal de Contas (e não julgadas por tal órgão consoante disposição do artigo 71, II da Constituição Federal). ${ }^{494}$

Discorrendo sobre o tema, o Relator, Ministro Sepúlveda Pertence, citando o voto do Acórdão condutor do Ministro Celso de Mello, assim se manifestou:

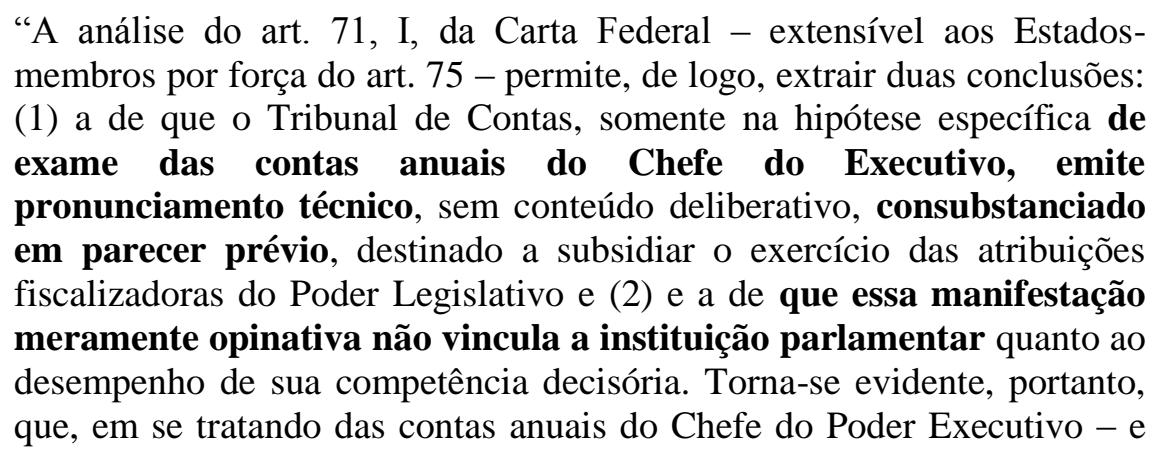

${ }^{492}$ FUGAGNOLI, Maria Carolina Barros Carvalho. Op. cit. p. 895.

${ }^{493}$ Dispunha o inciso I do artigo 47 da Constituição Estadual do Mato Grosso com redação dada pela Emenda Constitucional n ${ }^{\circ}$ 01/91: "Art. $1^{\circ}$. O inciso I do artigo 47 da Constituição Estadual passa a ter a seguinte redação: Art. 47. (...). I - apreciar as contas prestadas anualmente pelo Governador do Estado, e pela Mesa da Assembléia Legislativa, mediante parecer prévio a ser elaborado em sessenta dias a contar do seu recebimento e enviado à Assembléia Legislativa para julgamento. Art. $2^{\circ}$. Esta Emenda Constitucional entra em vigor na data de sua promulgação". A redação original do artigo 47, I, da Constituição do Estado do Mato Grosso repetia, por simetria, a disposição do artigo 71, I, da Constituição Federal. Para detalhes, consultar: Ação Direta de Inconstitucionalidade no 849-8/Mato Grosso. Rel. Min. Sepúlveda Pertence. Por maioria de votos julgada procedente a ação direta e, em consequência, declarada a inconstitucionalidade da Emenda Constitucional $\mathrm{n}^{\circ}$ 1, de 10/12/91, do Estado do Mato Grosso. Julgado em 11 de fevereiro de 1999. p. 50. Disponível em <http://redir.stf.jus.br/paginadorpub/paginador.jsp?docTP=AC\&docID=266565>, acesso em 12 de dez. 2011.

${ }^{494}$ Lembramos que consoante disposição constitucional dos incisos I e II do artigo 71 da Constituição Federal que, simetricamente se aplica aos Estados-membros, o Tribunal de Contas do Estado deve apreciar as contas de governo do Governador mediante a elaboração de um parecer prévio e julgar todas as demais contas dos administradores, o que inclui o julgamento das contas da Mesa da Assembleia Legislativa. 
destas somente - as funções do Tribunal de Contas assumem o caráter de mero pronunciamento opinativo". ${ }^{495}$ (grifos nossos)

O que se verifica, dos posicionamentos citados, é que parte da doutrina e da jurisprudência do Supremo Tribunal Federal entendem que o parecer prévio elaborado pelo Tribunal de Contas, quando aprecia as contas de governo, é peça de cunho técnico que, porém, não tem o condão de vincular a decisão a ser tomada pelo Parlamento, que poderá mantê-lo ou não e, inclusive decidir contrariamente a ele, tendo, pois, natureza meramente opinativa. O que prevalece e realmente tem peso, para esta corrente, é o julgamento político realizado pelo Poder Legislativo.

Este entendimento de que o parecer prévio é meramente opinativo não é, no entanto, uníssono.

Outra parte da doutrina defende, que, em âmbito municipal, o parecer prévio, apesar de não vincular, não é meramente opinativo. São exemplos dessa corrente Maria Carolina Barros Carvalho Fugagnoli, José Nilo de Castro e Antonio Carlos Doorgal de Andrada.

Maria Carolina Barros Carvalho Fugagnoli aduz que é o $\S 2^{\circ}$ do artigo 31 da Constituição Federal que impede que o parecer prévio, em âmbito municipal, seja meramente opinativo. Isto porque se exige, nesta situação, - rejeição do parecer - o voto de dois terços dos membros da Câmara Municipal para derrubar o parecer prévio do Tribunal de Contas. Nas palavras da autora:

\footnotetext{
"De acordo com o artigo 31, $\S \mathbf{2}^{\mathbf{0}}$ [da Constituição Federal], o parecer prévio só deixará de prevalecer por decisão de dois terços dos membros da Câmara Municipal. Nessa hipótese, não podemos afirmar que o parecer tem caráter meramente opinativo, visto que o Poder Legislativo só poderá alterá-lo se alcançar esse quorum". ${ }^{496}$ (grifos nossos)
}

No mesmo sentido, José Nilo Castro que assevera que:

\footnotetext{
${ }^{495}$ Ação Direta de Inconstitucionalidade $n^{\circ}$ 849-8/Mato Grosso. Rel. Min. Sepúlveda Pertence. Por maioria de votos julgada procedente a ação direta e, em consequência, declarada a inconstitucionalidade da Emenda Constitucional $\mathrm{n}^{\mathrm{o}}$ 1, de 10/12/91, do Estado do Mato Grosso. Julgado em 11 de fevereiro de 1999. p. 50. Disponível em <http://redir.stf.jus.br/paginadorpub/paginador.jsp?docTP=AC\&docID=266565>, acesso em 12 de dez. 2011.

${ }^{496}$ FUGAGNOLI, Maria Carolina Barros Carvalho. Op. cit. p. 896.
} 
"Já se disse, mas a importância da matéria nos suscita provocar de novo a questão. É que não se deve perder de vista a natureza jurídica do parecer prévio do Tribunal de Contas. Não se trata de simples opinião, já que, na forma do $\S 2^{\circ}$ do art. $31, \mathrm{CF}$, somente por $2 / 3$ dos membros da Câmara Municipal deixará de prevalecer. Assim, à Câmara Municipal, diante do parecer prévio, apresentam-se apenas duas alternativas, isto é, aprová-lo no que for conclusivo ou rejeitá-lo por maioria qualificada de $\mathbf{2} / \mathbf{3} "{ }^{497}$ (grifos nossos)

Destaca-se, ainda, o posicionamento de Antonio Carlos Doorgal de Andrada, Conselheiro do Tribunal de Contas do Estado de Minas Gerais, para o qual o parecer prévio detém "aspectos peculiares" que lhe retiram a característica de ser meramente opinativo. Consoante o autor:

\begin{abstract}
"Ademais, a reforçar os aspectos peculiares que encerram o parecer prévio, e que lhe alçam a uma condição para além de simples instrumento opinativo, estão a) a necessidade de quorum ultra qualificado para sua desconstituição $e$ b) as razões a serem expendidas para que ele deixe de prevalecer: assim, em relação ao Chefe do Executivo Municipal, o parecer do Tribunal só deixará de prevalecer com a expressa manifestação contrária de dois terços do Poder Legislativo, conforme disposto no art. $31, \S 2^{\circ}$, da $\mathrm{CF} / 88$, quorum este superior ao necessário para, por exemplo, aprovação de emendas constitucionais, exigindo-se ainda que a recusa do acatamento da manifestação do Órgão de Controle seja devidamente motivada, sob pena de nulidade". ${ }^{498}$ (grifos nossos)
\end{abstract}

Os posicionamentos citados são no sentido de que a exigência - em âmbito municipal ${ }^{499}$ - de quorum qualificado de dois terços - superior ao necessário para a

${ }^{497}$ CASTRO, José Nilo de. Op. cit. p. 490.

498 ANDRADA, Antonio Carlos Doorgal de. A natureza jurídica do parecer prévio emitido pelos Tribunais de Contas estaduais e admissibilidade de recurso. Disponível em: <www.antoniocarlosandrada.com.br/files/artigos/130420101521395500.pdf>, acesso em 12 de dez. 2010. p. 5 .

${ }^{499}$ Destacamos que o quorum qualificado de dois terços só é observado em âmbito municipal por expressa determinação do $\S 2^{\circ}$ do artigo 31 da Constituição Federal: "O parecer prévio, emitido pelo órgão competente sobre as contas que o Prefeito deve anualmente prestar, só deixará de prevalecer por decisão de dois terços dos membros da Câmara Municipal”. BRASIL. Constituição (1988). Constituição da República Federativa do Brasil: promulgada em 5 de outubro de 1988: atualizada até a Emenda Constitucional $\mathrm{n}^{\circ}$ 67, de 22-122010. 45 ed. ampl. São Paulo: Saraiva, 2011. p. 40. Na esfera federal o parecer prévio não é submetido a julgamento no Congresso Nacional. Na verdade, o Presidente encaminha suas contas ao Congresso Nacional por meio de uma mensagem presidencial. A Comissão Mista de Planos, Orçamentos Públicos e Fiscalização (CMO), formada por Deputados e Senadores, analisa, então, preliminarmente, as contas apresentadas pelo Presidente da República emitindo um parecer, isto na exegese do artigo 166, § $1^{\circ}$, I, da Constituição Federal. Em seguida, o parecer prévio emitido pelo Tribunal de Contas da União serve de embasamento para que a Comissão Mista elabore um projeto de decreto legislativo por meio do qual as contas do Presidente da República serão aprovadas ou rejeitadas. E o quorum para a aprovação do projeto de decreto legislativo, consoante disposto no $\S 7^{\circ}$ do artigo 166, que estabelece que "aplicam-se aos projetos mencionados neste artigo, no que não contrariar o disposto nesta Seção, as demais normas relativas ao processo legislativo" é o 
aprovação de emenda constitucional - somada ao fato da necessidade de motivação para a rejeição do parecer prévio, torna impossível afirmar que a natureza do parecer prévio porte caráter meramente opinativo.

Isto não quer dizer que o parecer prévio se torna vinculante, porém, também não admite, esta corrente, entendê-lo como documento meramente opinativo.

A questão é tão importante que ensejou o reconhecimento da existência de Repercussão Geral no Recurso Extraordinário no 597.362-0/Bahia, em curso perante o Supremo Tribunal Federal.

\section{Mencionado Recurso Extraordinário foi interposto pela "Coligação} Jaguaripe Não Pode Parar", contra decisão em Agravo Regimental em Recurso Especial Eleitoral que, ao analisar o registro da candidatura de um Prefeito, entendeu que não era possível falar em rejeição das contas do Chefe do Executivo municipal enquanto não houvesse o julgamento pela Câmara dos Vereadores, ainda que o Tribunal de Contas tivesse opinado pela sua não-aprovação ${ }^{500}$.

do artigo 47 da Constituição Federal, que dispõe: “Art. 47. Salvo disposição constitucional em contrário, as deliberações de cada Casa e de suas comissões serão tomadas por maioria dos votos, presente a maioria absoluta de seus membros". (grifos nossos). Ressalte-se, ainda, que o projeto de decreto legislativo pode estar ou não em consonância com o parecer prévio do Tribunal de Contas da União. BRASIL. Constituição (1988). Constituição da República Federativa do Brasil: promulgada em 5 de outubro de 1988: atualizada até a Emenda Constitucional no 67, de 22-12-2010. 45 ed. ampl. São Paulo: Saraiva, 2011. p. 132 e p. 55, respectivamente. Ou seja, o quorum para a aprovação ou rejeição do decreto legislativo, em âmbito federal, é o da maioria simples enquanto na esfera municipal, além de o parecer prévio ser diretamente julgado pela Câmara Municipal, exige-se o quorum da maioria qualificada de dois terços para esta derrubar o parecer prévio do Tribunal de Contas, que opinou pela aprovação ou rejeição das contas de governo do Prefeito. Informações a respeito da maioria necessária para derrubar o parecer prévio do Tribunal de Contas da União obtidas junto à Coordenação de Relacionamento, Pesquisa e Informação (Corpi) do Centro de Documentação e Informação (Cedi) da Câmara dos Deputados, Anexo II, enviadas pelo e-mail <informa.cedi@camara.gov.br>, acesso em 17 de jan. 2011.

${ }^{500}$ Eis a ementa do acórdão proferido no Tribunal Superior Eleitoral citada pelo Ministro Marco Aurélio quando de seu pronunciamento sobre a existência de repercussão geral no Recurso Extraordinário $\mathrm{n}^{\circ}$ 597.362-0/Bahia. Ressalte-se, ademais, que este Recurso foi julgado antes da vigência da Lei Complementar $\mathrm{n}^{\circ}$ 135/2010, a Lei da "Ficha Limpa". A ementa é a seguinte: "Registro de candidatura. Prefeito. Inelegibilidade. Art. $1^{\circ}$, I, "g", da Lei Complementar $\mathrm{n}^{\circ}$ 64/90. Competência. 1. A competência para o julgamento das contas de prefeito é da Câmara Municipal, cabendo ao Tribunal de Contas a emissão de parecer prévio, o que se aplica tanto anualmente pelo Chefe do Poder Executivo, quanto às contas de gestão ou atinentes à função de ordenador de despesas. 2. Não há falar em rejeição de contas de prefeito por mero decurso de prazo para sua apreciação pela Câmara Municipal, porquanto constitui esse Poder Legislativo o órgão competente para esse julgamento, sendo indispensável o seu efetivo pronunciamento. Agravo regimental a que se nega provimento". Repercussão Geral em Recurso Extraordinário no 597.362-0/Bahia. Rel. Min. Eros Grau. Reconhecida a Repercussão Geral em 20 de março de 2009. Pronunciamento do Min. Marco Aurélio quanto à existência de Repercussão Geral em 25 de março de 2009. Disponível em $<$ http://redir.stf.jus.br/paginadorpub/paginador.jsp?docTP=AC\&docID=595603〉, acesso em 14 de dez. 2011. 
A “Coligação Jaguaripe Não Pode Parar” recorreu, então, extraordinariamente, ao Supremo Tribunal Federal, sustentando que, na exegese do $\S 2^{\circ}$ do artigo 31 da Constituição Federal, o parecer prévio do Tribunal de Contas que tenha rejeitado as contas do Prefeito deve prevalecer enquanto não houver o julgamento da Câmara dos Vereadores. Em outras palavras, enquanto o Poder Legislativo municipal não julgar as contas do Prefeito, prevaleceria o decidido pelo Tribunal de Contas, em sede de parecer prévio. Ou seja, se o parecer prévio da Corte de Contas for pela rejeição das contas do Prefeito, enquanto não houver o julgamento pela Câmara Municipal, o Prefeito ficaria inelegível. Eis a sustentação da "Coligação Jaguaripe Não Pode Parar" nas palavras do Ministro Marco Aurélio:

"No extraordinário interposto com alegada base no artigo 102, inciso III, alínea "a", da Constituição Federal, a recorrente articula com a transgressão do artigo 31 do mesmo diploma. Sustenta existir verdadeira presunção constitucional em favor do parecer do Tribunal de Contas, que só deixará de prevalecer se o Legislativo Municipal, por maioria qualificada de dois terços dos seus membros, decidir expressamente pela aprovação das contas. Em outros termos, omissa a Câmara, prevalece o entendimento do Tribunal de Contas, com a consequente inelegibilidade do ex-Prefeito. Conforme as razões do recurso, entendimento contrário resultaria na absoluta ineficácia do controle externo do Executivo municipal e na violação do princípio da moralidade". ${ }^{501}$ (grifos nossos)

A matéria ainda não foi decidida definitivamente pelo Supremo Tribunal Federal. Por enquanto, o Ministro Marco Aurélio reconheceu a existência de repercussão geral nos seguintes termos:

"Cumpre dizer se a ausência de manifestação da Câmara resulta na prevalência do parecer do Tribunal de Contas e, portanto, de conclusão sobre a imprestabilidade das contas anuais prestadas pelo Prefeito, enquanto não vem à baila o crivo em sentido contrário da Câmara Municipal, quase sempre a atuar com maioria vinculada ao Poder Executivo. Com acerto percebeu o Ministro Eros Grau o envolvimento de valores constitucionais de maior envergadura, presente,

${ }^{501}$ Repercussão Geral em Recurso Extraordinário no 597.362-0/Bahia. Rel. Min. Eros Grau. Reconhecida a Repercussão Geral em 20 de março de 2009. Pronunciamento do Min. Marco Aurélio quanto à existência de Repercussão Geral em 25 de março de 2009. Disponível em <http://redir.stf.jus.br/paginadorpub/paginador.jsp?docTP=AC\&docID=595603>, acesso em 14 de dez. 2011. 
até mesmo, o zelo com a coisa pública. Pronuncio-me pela existência de repercussão geral". ${ }^{502}$ (grifos nossos)

Ora, se se discute se o parecer prévio deve prevalecer enquanto não for rejeitado por dois terços dos membros da Câmara dos Vereadores, é porque desempenha ele importante papel na apreciação das contas, não sendo, como entendem alguns doutrinadores, meramente opinativo. Mas sobre este tema voltaremos no item 5.6 (Os efeitos da atuação do Tribunal de Contas no âmbito municipal).

Destacamos, por oportuno, que em recente decisão do dia 07 de dezembro de 2011, o Ministro José Antônio Dias Toffoli emitiu o seu voto-vista no mencionado Recurso Extraordinário n 597362 asseverando, em contraposição ao voto do Relator, Ministro Eros Grau, que o parecer prévio produz efeitos da seguinte forma:

\begin{abstract}
“(...) desde que editado e apenas deixará de prevalecer se, e quando, apreciado e rejeitado por deliberação do Poder Legislativo municipal, com esteio na maioria qualificada de dois terços de seus membros.

Ou seja, enquanto não for formalmente derrubado por deliberação válida a ser emitida pelo órgão que detém competência para tanto, o mencionado parecer prévio do tribunal de contas prevalece íntegro para todos os efeitos". ${ }^{03}$ (grifos nossos)
\end{abstract}

E um dos efeitos da prevalência do parecer prévio é, consoante o Ministro, provocar a inelegibilidade do Prefeito que teve as suas contas rejeitadas pelo Tribunal de Contas por incidência no artigo $1^{\circ}$, I, "g", da Lei Complementar $n^{\circ}$ 64/90 com a redação dada pela Lei Complementar n ${ }^{\circ}$ 135/10, a Lei da "Ficha Limpa". E continua o Ministro:

"A observação empírica permite afirmar que há negligência por parte de Câmaras de Vereadores na apreciação desses pareceres, fato que apenas

\footnotetext{
${ }^{502}$ Repercussão Geral em Recurso Extraordinário no 597.362-0/Bahia. Rel. Min. Eros Grau. Reconhecida a Repercussão Geral em 20 de março de 2009. Pronunciamento do Min. Marco Aurélio quanto à existência de Repercussão Geral em 25 de março de 2009. Disponível em <http://redir.stf.jus.br/paginadorpub/paginador.jsp?docTP=AC\&docID=595603>, acesso em 14 de dez. 2011. ${ }_{503}$ Notícias do STF. Disponível em: <http://stf.jus.br/portal/cms/verNoticiaDetalhe.asp?idConteudo=195649>, acesso em 07 de jan. de 2012. Ressaltamos que o voto-vista do Ministro José Antônio Dias Toffoli não foi, até esta data, incluído no site do Supremo Tribunal Federal para consulta. Por esta razão, as informações apresentadas foram colhidas no próprio site do Tribunal, na parte "Notícias do STF".
} 
colabora para o descrédito da população no Poder Legislativo e que é ainda pior no regime democrático como um todo". ${ }^{504}$

A matéria é polêmica. Tanto é assim que a Ministra Cármen Lúcia Antunes Rocha pediu vista do Recurso Extraordinário em comento, adiando, pela segunda vez, o seu julgamento.

\subsubsection{A imprescindibilidade da elaboração do parecer prévio do Tribunal de Contas para o julgamento anual das contas municipais pela Câmara Municipal}

Já observamos que o parecer prévio, além de ser peça técnica, é também obrigatória, cabendo ao Tribunal de Contas, por meio dele, apreciar as contas de governo municipais e encaminhá-las à Câmara dos Vereadores para o julgamento político.

Assevera-se, neste momento, a imprescindibilidade da elaboração e apreciação do parecer prévio no âmbito do Tribunal de Contas para que, somente depois, possa ele ser julgado na Casa do Povo. Não se admite, assim, o sistema de aprovações fictas ou o denominado decurso de prazo, comumente adotados em regimes antidemocráticos. Como bem explica José Nilo de Castro:

\footnotetext{
"Nosso ordenamento constitucional abomina o sistema de aprovações fictas, isto é, se o Tribunal de Contas, no prazo estabelecido, para emitir o parecer prévio, não o fizer, não se entenderá como recomendada ou rejeitada a aprovação das contas". ${ }^{505}$
}

Quer dizer que o Tribunal de Contas tem que se pronunciar, tem que elaborar o parecer prévio que irá subsidiar o julgamento na Câmara Municipal. Não existe, pois, possibilidade jurídica de o Tribunal de Contas não elaborar o parecer prévio.

Tive a oportunidade de me manifestar sobre o tema em outro trabalho. Lá o fiz tratando do Tribunal de Contas da União, entretanto, consoante já explicado, graças à simetria constitucional, o regramento federal aplica-se, igualmente, no âmbito municipal. Naquela oportunidade asseverei: 


\begin{abstract}
"A elaboração deste parecer é prévia porque antecede ao julgamento das contas, efetuado pelo Congresso Nacional (controle político), que possui a competência decisória. Tem natureza opinativa, não vinculando, dessa forma, o Congresso Nacional, que poderá aprovar ou rejeitar as contas, contrariando ou não a conclusão exarada pelo Tribunal de Contas da União. É, no entanto, imprescindível a elaboração do parecer prévio e a sua ausência impede que o Congresso Nacional proceda ao julgamento das contas do Presidente da República. Caso, no entanto, o faça, sem o parecer prévio, o julgamento é nulo". ${ }^{006}$ (grifos nossos)
\end{abstract}

De outra parte, sobre a impossibilidade da existência de aprovações fictas, já se manifestou o Supremo Tribunal Federal, no julgamento da Ação Direta de Inconstitucionalidade n ${ }^{\circ}$ 215-5/Paraíba, eis que a Constituição do Estado da Paraíba previu norma que determinava a aprovação ficta das contas do Executivo no caso de o Tribunal de Contas não elaborar o parecer prévio no prazo determinado de um ano. Estabelecia o artigo 13 da Constituição:

“Art. 13. (...). § $7^{\circ}$. A partir da data do recebimento das contas do Município, o Tribunal de Contas terá o prazo de um ano para emitir o seu parecer, findo o qual, não havendo manifestação, entender-se-á como recomendada a aprovação". 507

O Relator, Ministro Celso de Mello, concedeu liminar para suspender a eficácia da expressão "findo o qual, não havendo manifestação, entender-se-á como recomendada a aprovação", contida no $\S 7^{\circ}$ do artigo 13 supramencionado, por entender que a Constituição do Estado da Paraíba não poderia criar um novo método de aprovação das contas, porque este se apresenta em desacordo com o disposto no artigo 75 da Constituição Federal, que determina que as normas estabelecidas em âmbito federal se aplicam, no que couber, aos Estados-membros e municípios. Assim, inexistindo sistema de

\footnotetext{
${ }^{506}$ FAGUNDES, Tatiana Penharrubia. A função... Op. cit. p. 241.

${ }^{507}$ Medida Cautelar em Ação Direta de Inconstitucionalidade n ${ }^{\circ}$ 215-5/Paraíba. Rel. Min. Celso de Mello. Por v.u., deferido em parte o pedido liminar para suspender, até o julgamento final da ação, a vigência do $\S$ $6^{\circ}$ do artigo 71 da Constituição do Estado da Paraíba e, no $\S 7^{\circ}$ do artigo 13, da mesma Constituição, as expressões "findo o qual, não havendo manifestação, entender-se-á como recomendada a aprovação" e, ainda, no artigo 12 do Ato das Disposições Transitórias da mesma Constituição, as seguintes expressões "Considerando-se como recomendada a sua aprovação se, findo este prazo, não tiver havido manifestação a respeito". Também por unanimidade o Tribunal indeferiu o pedido de liminar quanto ao inciso II, do art. 71, da Constituição do Estado da Paraíba. Julgada em 07/06/90. Disponível em <http://redir.stf.jus.br/paginadorpub/paginador.jsp?docTP=AC\&docID=346256>, acesso em 12 de dez. 2011. A ementa do Acórdão é a seguinte: "Ação Direta de Inconstitucionalidade - Constituição do Estado da Paraíba - Tribunal de Contas Estadual - Limitação de seus poderes - Instituição de sistema de aprovações fictas - Divergência com o modelo federal - Medida cautelar - deferimento parcial.
} 
aprovação ficta em âmbito federal, não há que se falar no referido sistema em esfera estadual. Sobre o tema pronunciou-se o Relator, Ministro Celso de Mello:

\begin{abstract}
"A questão que se coloca nestes autos é a de definir os exatos limites em que os Estados-membros poderão estabelecer a disciplina constitucional dos seus respectivos Tribunais de Contas, a partir do que se contém no art. 75 da Constituição Federal.

Os limites da atuação do poder constituinte estadual, em face do modelo federal adotado pela Constituição de 1988, estão a exigir, ainda, precisa definição de sua abrangência.

(...)

Tendo presente o fato de que esta Corte não teve oportunidade de se manifestar, em definitivo, sobre o tema, penso ser impositiva a suspensão liminar da eficácia de dispositivos que, afastando-se do parâmetro contido no Texto Maior, estipulam prazos peremptórios para atuação de Tribunal de Contas estadual, cuja inobservância (...) traduzirá presunção de manifestação favorável (art. $13, \S 7^{\circ}$ da Constituição estadual e $(\ldots) "$. 508
\end{abstract}

Verifica-se que o Relator concedeu liminar para suspender norma da Constituição do Estado da Paraíba que autorizava a aprovação ficta das contas estaduais quando ocorria o decurso do prazo sem que o Tribunal de Contas tivesse apreciado as contas e emitido o parecer prévio.

Quer isto dizer que a manifestação do Tribunal de Contas, por meio de seu parecer prévio, é imprescindível.

No mesmo sentido manifesta-se Jorge Ulisses Jacoby Fernandes:

"Ao contrário do que alhures eventualmente preconizam, o parecer prévio sobre as contas é indispensável, sendo nulo o julgamento diretamente pelo Poder Legislativo sem a prévia e formal manifestação da Corte

\footnotetext{
${ }^{508}$ Medida Cautelar em Ação Direta de Inconstitucionalidade no 215-5/Paraíba. Rel. Min. Celso de Mello. Por v.u., deferido em parte o pedido liminar para suspender, até o julgamento final da ação, a vigência do $\S$ $6^{\circ}$ do artigo 71 da Constituição do Estado da Paraíba e, no $\S 7^{\circ}$ do artigo 13, da mesma Constituição, as expressões "findo o qual, não havendo manifestação, entender-se-á como recomendada a aprovação" e, ainda, no artigo 12 do Ato das Disposições Transitórias da mesma Constituição, as seguintes expressões "Considerando-se como recomendada a sua aprovação se, findo este prazo, não tiver havido manifestação a respeito". Também por unanimidade o Tribunal indeferiu o pedido de liminar quanto ao inciso II, do art. 71, da Constituição do Estado da Paraíba. Julgada em 07/06/90. Disponível em: <http://redir.stf.jus.br/paginadorpub/paginador.jsp?docTP=AC\&docID=346256>, acesso em 12 de dez. 2011.
} 
de Contas. Mesmo que vencido o prazo para emissão do parecer prévio, não pode o parlamento julgar diretamente". ${ }^{509}$

Comprovada a necessidade de o Tribunal de Contas elaborar o parecer prévio, passamos, em seguida, a analisar o papel da Câmara Municipal na função fiscalizadora das contas de governo municipais.

\subsection{A participação da Câmara Municipal na função fiscalizadora das "contas de governo" anualmente prestadas pelo Prefeito: o julgamento das contas municipais}

Após elaborado e apreciado no Tribunal de Contas, o parecer prévio, aprovando ou rejeitando as contas de governo prestadas pelo Prefeito, é encaminhado para o julgamento político na Câmara dos Vereadores. Isto porque a tarefa do Tribunal de Contas consiste em apreciar as contas anualmente apresentadas pelo Prefeito. E apreciar, como já estudado, quer dizer "avaliar”, “analisar", "examinar” as contas.

Em que consiste, então, a competência julgadora concernente à Câmara dos Vereadores? Comecemos por definir o significado de “julgar”.

O Dicionário Melhoramentos da Língua Portuguesa apresenta nove acepções para o vocábulo, dentre as quais: “1. Decidir, resolver como juiz ou como árbitro; lavrar ou pronunciar sentenças; 2. Pronunciar uma sentença; 3. Apreciar, avaliar, formar um juízo a respeito de; 4. Formar juízo crítico acerca de; avaliar". 510

O Dicionário Eletrônico Houaiss da Língua Portuguesa, no mesmo sentido, exibe cinco conceitos para "julgar", dentre eles: "1. Tomar (uma decisão), na qualidade de juiz; 1.1. Sentenciar, pronunciar uma sentença (de condenação ou de

\footnotetext{
${ }^{509}$ FERNANDES, Jorge Ulisses Jacoby. Op. cit. p. 342. O autor cita, ainda, em sua nota de rodapé 727 a Súmula 31 do Tribunal de Contas do Estado de Minas Gerais: "É ineficaz e de nenhuma validade a resolução da Câmara Municipal que aprova ou rejeita as contas do Prefeito antes da emissão do parecer prévio do Tribunal de Contas". (grifos nossos). Idem. Ibidem.

510 DICIONÁRIO Melhoramentos da Língua Portuguesa. Antônio Houaiss (apresentação). São Paulo: Melhoramentos, 1994. p. 593. Os outros significados são: "5. Formar conceito sobre alguém ou alguma coisa; 6. Apreciar os próprios pensamentos, palavras e obras (...); 7. Entender, imaginar, supor; 8. Considerar (-se), entender (-se), reputar(-se), ter(-se) por”. DICIONÁRIO Melhoramentos da Língua Portuguesa. Antônio Houaiss (apresentação). São Paulo: Melhoramentos, 1994. p. 593.
} 
absolvição); 2. Emitir parecer, opinião sobre (alguém ou alguma coisa) formar conceito, opinião; 3. Decidir, após reflexão; considerar". 511

Entendemos que "julgar", no âmbito do nosso trabalho, é mais do que "apreciar, avaliar, formar um juízo a respeito de". Julgar é "decidir, resolver como juiz ou como árbitro", "tomar uma decisão na qualidade de juiz". É decidir - com definitividade $^{512}$ - se as contas de governo anualmente prestadas pelo Prefeito devem ser aprovadas ou rejeitadas, mantendo-se ou derrubando-se o parecer prévio elaborado pelo Tribunal de Contas.

Ressaltamos que o parecer prévio pode propor a aprovação ou a rejeição das contas e que, para a Câmara Municipal desconstituir a decisão do Tribunal de Contas, são necessários dois terços dos votos dos seus membros. Isto é, se o parecer prévio foi pela aprovação das contas e a Câmara Municipal entender que o mesmo não deve prevalecer, necessita alcançar dois terços dos votos de seus membros. Da mesma forma, se o parecer prévio tiver concluído pela rejeição das contas e a Câmara Municipal entender em sentido contrário, também precisará de dois terços dos votos de seus membros para derrubar o parecer prévio elaborado pelo Tribunal de Contas.

Em qualquer das hipóteses, a decisão final pela aprovação ou não das contas de governo apresentadas pelo Prefeito fica a cargo da Câmara Municipal, à qual compete o julgamento político das mesmas. É este julgamento pela Casa das Leis, ademais, que pode causar a inelegibilidade do Prefeito que tiver suas contas rejeitadas pela Câmara Municipal e que pretender se candidatar ao mesmo ou a outro cargo eletivo. Não se admite tal conseqüência imediata - inelegibilidade do Prefeito - quando o parecer prévio do Tribunal de Contas opinar pela rejeição das contas. É este o entendimento do Tribunal Superior Eleitoral, proferido quando das eleições de 2010, já na vigência da Lei da "Ficha Limpa". Decidiu o Tribunal:

${ }^{511}$ DICIONÁRIO Eletrônico Houaiss da Língua Portuguesa. Instituto Antônio Houaiss. Rio de Janeiro: Objetiva, 2001. 1 CD-ROM. "Julgar" é, também: "4. Decidir que algo pertence a ou se transfere para (outrem); adjudicar; 5. Supor(-se), imaginar(se), considerar(-se), pensar". DICIONÁRIO Eletrônico Houaiss da Língua Portuguesa. Instituto Antônio Houaiss. Rio de Janeiro: Objetiva, 2001. 1 CD-ROM.

${ }^{512}$ Nada impede, no entanto, que o Prefeito recorra ao Poder Judiciário se entender que uma ilegalidade ou inconstitucionalidade foi praticada durante o processo interno na Câmara dos Vereadores que concluiu pela aprovação ou rejeição das contas. Isto é decorrência do disposto no inciso XXXV do artigo $5^{\circ}$ da Constituição Federal que determina que "a lei não excluirá da apreciação do Poder Judiciário lesão ou ameaça a direito". BRASIL. Constituição (1988). Constituição da República Federativa do Brasil: promulgada em 5 de outubro de 1988: atualizada até a Emenda Constitucional n ${ }^{\circ}$ 67, de 22-12-2010. $45^{\text {a }}$ ed. ampl. São Paulo: Saraiva, 2011.p. 7. 
"AGRAVO REGIMENTAL. RECURSO ORDINÁRIO. REGISTRO DE CANDIDATURA. ELEIÇÕES 2010. DEPUTADO ESTADUAL. INELEGIBILIDADE. ART. $1^{\circ}, \mathrm{I}, \mathrm{g}$, da LEI COMPLEMENTAR $\mathrm{N}^{\circ}$ 64/90. CONTAS DE PREFEITO. ORDENADOR DE DESPESAS. JULGAMENTO. COMPETÊNCIA. CÂMARA MUNICIPAL. NÃO PROVIMENTO.

1. Nos termos do art. 31 da Constituição Federal, a Câmara Municipal é o órgão competente para o julgamento das contas de prefeito, ainda que ele seja ordenador de despesas, cabendo ao Tribunal de Contas tão somente a emissão de parecer prévio. Precedente: RO no 751-79/TO, Rel. Min. Arnaldo Versiani, PSESS de 8.9.2010.

2. Na espécie, as contas do agravado, prefeito e ordenador de despesas, relativas ao exercício de 2004 foram desaprovadas pelo TCE/TO, não havendo, porém, notícia de apreciação das mencionadas contas pela Câmara Municipal de Xambioá/TO, razão pela qual $\underline{\mathbf{N A ̃ O}}$ incide a hipótese de inelegibilidade prevista no art. $1^{\circ}$, I, g, da Lei Complementar $n^{0}$ 64/90.

3. Agravo regimental não provido". ${ }^{513}$ (grifos nossos)

Observa-se, portanto, que o julgamento - e não apenas a apreciação - é que é capaz de gerar a inelegibilidade do Prefeito que prestou contas. É dizer, enquanto a Câmara Municipal não "decidir definitivamente", julgando essas contas, o Prefeito não pode ser considerado inelegível, ainda que o Tribunal de Contas tenha, no seu parecer prévio, opinado pela rejeição das contas, o que pode, porém, significar, pelo menos no aspecto técnico, que o Chefe do Executivo municipal não utilizou devidamente o dinheiro público.

“Julgar" é, portanto, mais forte que "apreciar". Quem julga decide. Somente o julgamento ${ }^{514}$ é apto a produzir, como conseqüência, a inelegibilidade do Prefeito. E quem julga é a Câmara Municipal.

\subsubsection{O julgamento político realizado pela Câmara Municipal}

Inicialmente, convém esclarecer o trâmite interno ${ }^{515}$ do parecer prévio depois que ele chega à Câmara Municipal. É encaminhado, pelo Presidente da

\footnotetext{
${ }^{513}$ Recurso Ordinário no 67033 - Palmas/TO. Rel. Min. Aldir Guimarães Passarinho Junior. “O Tribunal, por unanimidade, desproveu o agravo regimental, nos termos do voto do Relator". Publicado em Sessão de 07/10/10. Disponível em <http://www.tse.jus.br/internet/jurisprudencia/index.htm>, acesso em 15 de jun. 2011. No mesmo sentido o Agravo Regimental em Recurso Ordinário no 462727/Fortaleza (Ceará), Rel. Min. Marcelo Henrique Ribeiro de Oliveira, publicado no Diário da Justiça Eletrônico do dia 11/04/11, pp. 30-31. Disponível em <http://www.tse.jus.br/jurisprudencia/inteiro-teor>, acesso em 15 de jun. 2011.

${ }^{514}$ Lembre-se que o Tribunal de Contas também julga os administradores - à exceção do Prefeito - que utilizam os recursos públicos (artigo 71, II, da Constituição Federal). Neste caso, como já analisamos, a decisão do Tribunal de Contas pela rejeição das contas do administrador público é capaz de gerar a sua inelegibilidade.
} 
Edilidade, à Comissão de Finanças e Orçamento para apreciação. O Presidente desta Comissão designa um Relator, que elaborará um parecer sobre o parecer prévio. No entanto, é o próprio parecer prévio do Tribunal de Contas que é submetido a julgamento no Plenário da Câmara.

Ademais, há que se observar que é o artigo 49, IX, da Constituição Federal, que estabelece a competência privativa do Congresso Nacional para o julgamento anual das contas prestadas pelo Presidente da República, inciso este que se aplica simetricamente ao âmbito municipal, ou seja, o julgamento das contas anualmente prestadas pelo Prefeito é obrigação da Câmara Municipal e não do Tribunal de Contas.

Significa, então, que o parecer prévio elaborado pelo Tribunal de Contas, ainda que tenha entendido pela rejeição das contas de governo prestadas pelo Prefeito, não gera consequências enquanto não houver o julgamento final realizado pela Câmara Municipal. Nesse sentido, a Ação Direta de Inconstitucionalidade nº 2.631-3/Pará, cujo Relator, Ministro Carlos Velloso, assim se pronunciou:

\begin{abstract}
"As contas foram prestadas. O que aconteceu é que o Tribunal de Contas do Estado emitiu parecer prévio no sentido de sua rejeição.

Acontece que, em tal caso, o Tribunal de Contas age como órgão auxiliar do Legislativo Municipal: CF, art. $31, \S \S 1^{\circ}$ e $2^{\circ}$. A fiscalização do Município, estatui o art. 31, caput, da CF, é exercida pelo Legislativo Municipal, mediante controle externo, e pelos sistemas de controle interno do Poder Executivo Municipal, na forma da lei. O controle externo da Câmara Municipal é exercido com o auxílio do Tribunal de Contas $\left(\S 1^{\circ}\right)$, certo que o 'parecer prévio, emitido pelo órgão competente, sobre as contas que o Prefeito deve anualmente prestar, só deixará de prevalecer por decisão de dois terços dos membros da Câmara Municipal $\left(\S 2^{\circ}\right)^{\prime}$.
\end{abstract}

\footnotetext{
${ }^{515} \mathrm{O}$ trâmite interno do parecer prévio foi esclarecido pela Câmara Municipal após a seguinte pergunta por mim endereçada à Ouvidoria da Casa: "Gostaria de saber qual é o trâmite interno depois que o Tribunal de Contas do Município de São Paulo elabora o parecer prévio sobre as contas do Prefeito e o encaminha à Câmara Municipal. Quando ele chega na Câmara, deve receber um parecer da Comissão de Orçamento ou é o próprio parecer prévio que é levado a julgamento no Plenário da Câmara, quando, somente pelo voto de dois terços dos membros o parecer prévio deixa de prevalecer? É elaborado um decreto legislativo como ocorre no âmbito federal?". E a resposta: "Prezada Cidadã Tatiana Fagundes, em resposta ao seu questionamento, informamos que, conforme art. 386 do Regimento Interno da Câmara Municipal de São Paulo (CMSP), o parecer prévio do Tribunal de Contas do Município (TCM) é imediatamente encaminhado pelo Presidente da Câmara Municipal à Comissão de Finanças e Orçamento para apreciação. O Presidente da Comissão de Finanças e Orçamento, por sua vez, designa um relator para elaborar um parecer sobre o parecer do Tribunal de Contas do Município, que será votado na Comissão. No entanto, o parecer prévio do Tribunal de Contas do Município é que será levado para votação no Plenário da Câmara. Diferentemente do âmbito federal, não é elaborado decreto legislativo. (...) Atenciosamente, Ouvidoria do Parlamento - Câmara Municipal de São Paulo. Disponível em: 〈http://www.camara.sp.gov.br/index.php>. Acesso em 16 de mar. 2011.
} 
No caso, a Câmara Municipal não se manifestou, não podendo ser considerado, como definitivo, o parecer prévio do Tribunal de Contas do Estado". ${ }^{516}$ (grifos nossos)

Observa-se, do voto do Ministro Carlos Velloso, que a decisão do Tribunal de Contas não é definitiva, posto que depende de confirmação ou não pela Câmara Municipal, por ocasião do julgamento das contas de governo.

Assevera-se, ademais, que este julgamento tem especial importância na medida em que somente ele - se entender pela rejeição das contas - é capaz de causar a inelegibilidade do Prefeito.

E, em que consiste este julgamento político?

De acordo com Cláudio Ferreira, consiste em um juízo de valor que a Câmara Municipal realiza sobre o uso que o Prefeito conferiu aos recursos públicos. Nas palavras do autor:

\begin{abstract}
"O julgamento das contas, portanto, não tem somente a conotação de um procedimento administrativo de apuração de legalidade, no qual se confrontam os atos praticados com as normas que o regem, mas tem a natureza de um julgamento político, no qual o parâmetro é um juízo de valor.

Assim, se o prestador de contas tiver contra si a acusação da prática de um ato ilegal, pode se defender no âmbito do controle judicial, em processo que apurará a legalidade do ato praticado. Se, porém, pairar contra si a acusação de não ter feito as escolhas adequadas para atender às necessidades da população, não terá como levar a discussão ao Judiciário, pois que se trata de avaliação política.

Nesse caso, o foro apropriado para esse debate é o do próprio Legislativo e o momento apropriado é o do julgamento das contas". ${ }^{517}$ (grifos nossos)
\end{abstract}

Semelhante é o posicionamento de Geraldo Ataliba para o qual os atos de natureza política não são passíveis de revisão, quanto ao mérito, por outro órgão. Assevera o autor:

\footnotetext{
${ }^{516}$ Ação Direta de Inconstitucionalidade no 2.631-3/Pará, Rel. Min. Carlos Velloso, julgada em 29/08/02 e publicada no Diário de Justiça de 08/08/03. Disponível em: <http://redir.stf.jus.br/paginadorpub/paginador.jsp?docTP=AC\&docID=266865>, acesso em 18 de dez. 2011. ${ }^{517}$ FERREIRA, Cláudio. O julgamento das contas públicas e o sistema de controle parlamentar do governo na Constituição Brasileira de 1988. Dissertação de Mestrado. Orientador Prof. Elival da Silva Ramos. Faculdade de Direito. São Paulo: 2011. p. 139.
} 
"Deveras, legislar, aprovar o orçamento, conhecer e julgar crimes de responsabilidade, por exemplo (funções do Congresso), ou iniciar o processo legislativo, nomear ministros e administradores de Territórios, remeter mensagem ao Congresso sobre a situação do país etc. (atribuições do presidente da república), são atos de natureza política, porque - embora editados com respeito aos quadros legais - não dependem de lei, nem esta pode ser posta como condição para sua prática. Por outro lado, esses atos são insuscetíveis de revisão, quanto ao mérito, por qualquer outro órgão". ${ }^{518}$ (grifos nossos)

Embora não listado dentre os exemplos do autor, o julgamento pela Câmara Municipal das contas de governo anualmente prestadas pelo Prefeito é exemplo de ato político. Ressalte-se, como já observado anteriormente, que nada impede o ingresso do Prefeito no Judiciário para tentar reverter a decisão da Edilidade. A decisão judicial poderá ser-lhe favorável se, no julgamento da Câmara Municipal, tiver ocorrido uma ilegalidade ou inconstitucionalidade.

Destacamos, ainda, o pronunciamento de Rodrigo Oliveira de

Faria:

"O controle efetuado pelo Poder Legislativo é, sobretudo, um controle político. A corroborar tal afirmativa temos que o parecer prévio sobre as contas anuais do Governo oferecido pelo Tribunal de Contas, embora indispensável, pode ser rechaçado, não vinculando a decisão (política) do Parlamento". ${ }^{519}$ (grifos nossos)

O julgamento político, ao mesmo tempo em que permite ao Legislativo realizar o controle político dos atos praticados pelo Chefe do Executivo municipal tem, no entanto, um lado sombrio: é que, exatamente por ser político o julgamento, basta que o Prefeito obtenha a maioria na Câmara Municipal para que tenha suas contas de governo aprovadas, ainda que o parecer prévio elaborado pelo Tribunal de Contas - parecer técnico - tenha opinado pela rejeição das contas e, contrario sensu, o simples fato de o Prefeito não possuir a maioria pode provocar a rejeição de suas contas, mesmo que o parecer prévio da Corte de Contas tenha opinado pela sua aprovação. Nos

\footnotetext{
${ }^{518}$ ATALIBA, Geraldo. República e Constituição. $2^{\mathrm{a}}$ ed. $4^{\mathrm{a}}$ tiragem. atual. por Rosalea Miranda Folgosi. São Paulo: Malheiros, 2007. pp. 56-57.

519 FARIA, Rodrigo Oliveira de. Título VIII - Do controle da execução orçamentária. In: Orçamentos públicos: a Lei 4.320/1964 comentada. CONTI, José Maurício (Coord.). São Paulo: Revista dos Tribunais, 2008. p. 242.
} 
dizeres de Antonio Tito Costa, em obra de 1964 cuja lição, apesar de anterior à Constituição Federal de 1988, é válida nos dias de hoje:

"Como se vê, compete à Câmara, exclusivamente, tomar e julgar as contas do prefeito.

(...)

Se o prefeito tem maioria na Câmara, via de regra suas contas são aprovadas, estejam elas em ordem ou não. Se não tem maioria, elas são rejeitadas. Mas, no caso de rejeição, que é que acontece?

Freqüentemente, nada. A Câmara se acomoda, os vereadores, por vezes, deixam correr o tempo, sem qualquer providência em matéria que é de grande importância e gravidade. Sim, porque a rejeição das contas do prefeito, pela Câmara, significará, pelo menos, que elas não estão suficientemente claras ou que houve alguma despesa (grande ou pequena) que não foi justificada, ou escriturada convenientemente". ${ }^{520}$ (grifos nossos)

Prossegue, o autor, explicando que quem perde com o "descaso" da Câmara Municipal em proferir o julgamento das contas de governo é o povo, asseverando que o pacto de confiança decorrente do mandato popular é rompido. Nas palavras de Antonio Tito Costa:

"Então, já não cabe ao vereador, ùnicamente, o juízo sôbre a matéria. É o interesse público, o bem comum, que reclamam providências e a esse reclamo não pode o vereador deixar de atender, sob pena de estar traindo a confiança dos que lhe entregaram o mandato popular". ${ }^{521}$ (grifos nossos)

De se concluir, portanto, que a Câmara Municipal tem o dever de julgar as contas de governo anualmente prestadas pelo Prefeito e isto em razão do "pacto de confiança" havida entre o vereador e o povo que o elegeu, bem como em respeito ao princípio republicano, já que o grande beneficiado com a prestação de contas do Chefe do Executivo municipal é o povo.

${ }^{520}$ COSTA, Antonio Tito. O vereador e a Câmara Municipal: problemas municipais. São Paulo: Revista dos Tribunais, 1964. pp. 118-119.

${ }^{521}$ Idem. p. 119. 


\subsubsection{O critério constitucional para a rejeição do parecer prévio elaborado pelo Tribunal de Contas no âmbito do Município: a necessidade do voto de dois terços dos membros da Câmara Municipal}

Consoante já asseveramos, a Constituição da República Federativa do Brasil fixou, no $\S 2^{\circ}$ do artigo 31, que "o parecer prévio, emitido pelo órgão competente sobre as contas que o Prefeito deve anualmente prestar, só deixará de prevalecer por decisão de dois terços dos membros da Câmara Municipal". 522

Significa, então, que a Câmara Municipal necessita de dois terços dos votos de seus membros para derrubar o parecer prévio do Tribunal de Contas que tenha opinado pela aprovação ou pela rejeição das contas de governo anualmente prestadas pelo Prefeito.

Importante observar, que a maioria qualificada para derrubar o parecer prévio está de acordo com o ordenamento pátrio, apesar de este regramento não se repetir nas esferas federal e estaduais, nas quais se exige, tão somente, a maioria de votos, presentes a maioria absoluta dos membros no Congresso Nacional ou das Assembleias Legislativas, conforme o caso.

É que os artigos 70 a 75 da Constituição Federal, que estabelecem as normas gerais válidas para o Tribunal de Contas nas três esferas federativas, não prevêm o critério para aprovação ou rejeição das contas de governo do Presidente da República no que concerne ao quorum, de modo que não há que se falar em reprodução obrigatória, nos Estados-membros, nos Municípios e no Distrito Federal, do modelo de quorum de maioria simples $^{523}$, previsto genericamente para a esfera federal.

Ademais, em nosso entendimento, o fato de a própria Constituição Federal exigir, em âmbito municipal, o voto de dois terços dos membros da Câmara dos Vereadores para que o parecer prévio do Tribunal de Contas deixe de prevalecer determina

\footnotetext{
522 BRASIL. Constituição (1988). Constituição da República Federativa do Brasil: promulgada em 5 de outubro de 1988: atualizada até a Emenda Constitucional no 67, de 22-12-2010. 45 a ed. ampl. São Paulo: Saraiva, 2011. p. 40.

${ }_{523}$ É o que dispõe o artigo 47 da Lei Maior: "Salvo disposição constitucional em contrário, as deliberações de cada Casa e de suas Comissões serão tomadas por maioria dos votos, presente a maioria absoluta de seus membros". BRASIL. Constituição (1988). Constituição da República Federativa do Brasil: promulgada em 5 de outubro de 1988: atualizada até a Emenda Constitucional no 67 , de 22-12-2010. $45^{\mathrm{a}}$ ed. ampl. São Paulo: Saraiva, 2011. p. 55.
} 
a força e a importância que possui este documento, razão pela qual, pensamos, não se pode atribuir ao parecer prévio, em âmbito municipal, a natureza de documento meramente opinativo.

\subsection{A rejeição das contas de governo anuais dos Prefeitos do Município de São Paulo: os casos "Luíza Erundina" e "Celso Pitta"}

As contas de governo dos então Prefeitos Luíza Erundina de Souza e Celso Roberto Pitta do Nascimento, relativas aos anos de 1991 para ela e 1999 e 2000 para ele, foram rejeitadas pelo Tribunal de Contas do Município de São Paulo e mantidas, tais rejeições, pela Câmara Municipal de São Paulo.

Analisemos os principais motivos de cada uma delas.

\subsubsection{A rejeição das contas de governo da Prefeita Luíza Erundina de Souza}

O Tribunal de Contas do Município de São Paulo, no TC $\mathrm{n}^{\circ}$ 72.003.008.92-00 rejeitou as contas de governo prestadas pela então Prefeita Luíza Erundina, relativas ao ano de 1991.

Os motivos para a emissão de parecer prévio contrário à aprovação das contas podem ser observados na decisão do Pleno:

\footnotetext{
"DECIDE, à unanimidade, emitir PARECER PRÉVIO CONTRÁRIO à aprovação das Contas do Executivo, relativas ao exercício de 1991, com fundamento nas ilegalidades demonstradas a seguir: 1 - Não houve excesso de arrecadação, em decorrência, não poderia ocorrer abertura de crédito adicional suplementar com cobertura proveniente de excesso de arrecadação; 2 - Houve gastos com publicidade, além do permissivo legal; 3 - Inversão das prioridades orçamentárias em decorrência de transposições ilegais de recursos. As razões expostas nos itens 2 (dois) e 5 (cinco) deste parecer, conquanto justifiquem, por si, a emissão de parecer prévio contrário, motivaram transposições ilegais igualmente. 4 Contratações e recontratações de pessoal que contrariam a Emenda 4, à Lei Orgânica do Município de São Paulo; 5 - Dotações de pessoal.
} 
Transferência ilegal e inconstitucional de órgãos para órgãos e de dotação para dotação". 524

O parecer prévio foi encaminhado à Câmara Municipal, que decidiu por mantê-lo. Como resultado, as contas da então Prefeita Luíza Erundina foram rejeitadas definitivamente e, como consequência, ficaria ela inelegível, nos termos do artigo $1^{\circ}$, I, "g" "525, da Lei Complementar $n^{\circ}$ 64/90, antes da mudança operada pela Lei Complementar $\mathrm{n}^{\mathrm{o}} 135 / 10$.

Ocorre que a Prefeita recorreu ao Poder Judiciário contra a Câmara Municipal e o Tribunal de Contas do Município de São Paulo, alegando desrespeito ao princípio constitucional da ampla defesa, ausência de motivos para a rejeição de suas contas e desvio de poder. O MM. Juiz da $11^{\text {a }}$ Vara da Fazenda Pública julgou procedente o pedido da autora e declarou a nulidade do ato legislativo que rejeitou as contas municipais do ano de 1991, nos seguintes termos:

"JULGO PROCEDENTE o pedido para declarar a nulidade do ato legislativo que rejeitou as contas municipais do ano de 1991, apresentadas pela autora, pela ausência de motivação técnica a embasar tal decisão, devendo nova apreciação ser feita em sessão legislativa da Câmara Municipal, sem prejuízo de preservar-se o conteúdo de decisões proferidas naquele ato e que não guardem relação com o objeto desta causa". ${ }^{526}$ (grifos nossos)

Observe-se que o MM. Juiz de Direito decretou a nulidade do ato legislativo - e não do parecer prévio elaborado pelo Tribunal de Contas - determinando nova apreciação na Câmara Municipal. Dentre seus argumentos, o MM. Juiz de Direito entendeu não ter havido ferimento ao princípio da ampla defesa e sim "cerceamento de

\footnotetext{
${ }^{524}$ Balanço Geral ao Exercício de 1991, Prefeita Luíza Erundina de Souza. Parecer Prévio nos autos do TC n ${ }^{\circ}$ 72.003.008.92-00. Rel. Conselheiro Eurípedes Sales. Julgado em 24 de junho de 1992. V.u. contrário à aprovação das contas do Executivo. pp. 432-465.

${ }_{525}$ Dispunha o artigo $1^{\circ}$, I, "g", da Lei Complementar $n^{\circ}$ 64/90, antes da alteração dada pela Lei Complementar $\mathrm{n}^{\circ}$ 135/10: "Art. 1 ${ }^{\circ}$. São inelegíveis: I - para qualquer cargo: g) os que tiverem suas contas relativas ao exercício de cargos ou funções públicas rejeitadas por irregularidade insanável e por decisão irrecorrível do órgão competente, salvo se a questão houver sido ou estiver sendo submetida à apreciação do Poder Judiciário, para as eleições que se realizarem nos 5 (cinco) anos seguintes, contados a partir da data da decisão". BRASíLIA (BR). Lei Complementar nº 64, de 18 de maio de 1990. Estabelece, de acordo com o art. $14, \S 9^{\circ}$ da Constituição Federal, casos de inelegibilidade, prazos de cessação, e determina outras providências. Diário Oficial da União de 21 de maio de 1990.

${ }_{526}$ Processo no 0404493-06-1994.8.26.0053. $11^{\text {a }}$ Vara da Fazenda Pública. Ação Ordinária. Disponível em: $<$ http://esaj.tjsp.jus.br/cpo/pg/show.do?processo.codigo $=1$ HZWZF0CT0000\&processo.foro=53>, acesso em 02 de dez. 2011.
} 
defesa político", pois a então Prefeita não teria tido a oportunidade de se defender na Casa do Povo. Consoante o voto:

\begin{abstract}
"Tem razão quanto aos argumentos repelidos, porém, o convencimento do juízo não está assentado em cerceamento de defesa legal, uma vez que não se tratou de processo judicial, mas, cerceamento de defesa político, por que não se permitiu à autora o exercício de ação política para convencimento dos senhores vereadores.

(...)

Desrespeitado o direito político de qualquer gestor de coisa pública, no exercício de função pública, nasce para ele o direito de vir ao pálio do Judiciário buscar a reparação". ${ }^{527}$ (grifos nossos)
\end{abstract}

Destaque-se, que a r. sentença “ a quo” foi mantida pela $7^{\mathrm{a}}$ Câmara de Direito Público do Tribunal de Justiça de São Paulo que, por votação unânime, não conheceu dos Agravos Retidos e negou provimento aos recursos interpostos pelo Tribunal de Contas do Município de São Paulo, pela Câmara Municipal de São Paulo e pelo Ministério Público. O E. Tribunal de Justiça reconheceu, no entanto, o ferimento ao princípio da ampla defesa, tal como alegado pela Prefeita Luíza Erundina e manteve "a anulação dos atos que culminaram na rejeição de contas apresentadas pela autora (...)".528

Observa-se, então, que o julgamento das contas de governo da Prefeita Luíza Erundina, referentes ao exercício de 1991 e realizado pela Câmara Municipal foi anulado por decisão judicial, devendo realizar-se novo julgamento na Casa do Povo. Como a decisão da justiça é de dezembro de 2010, não há notícias de que o novo julgamento já tenha ocorrido.

\title{
5.3.2. A rejeição das contas de governo do Prefeito Celso Roberto Pitta do Nascimento
}

Em duas oportunidades as contas de governo do então Prefeito de São Paulo, Celso Roberto Pitta do Nascimento, foram rejeitadas pelo Tribunal de Contas

\footnotetext{
${ }^{527}$ Processo no 0404493-06-1994.8.26.0053. 11 ${ }^{\text {a }}$ Vara da Fazenda Pública. Ação Ordinária. Disponível em: $<$ http://esaj.tjsp.jus.br/cpo/pg/show.do?processo.codigo=1HZWZF0CT0000\&processo.foro=53>, acesso em 02 de dez. 2011.

${ }^{528}$ Apelação no ${ }^{\circ} 944.08 .164399-9$, Rel. Desembargador Nogueira Diefenthäler. $7^{\text {a }}$ Câmara de Direito Público do Tribunal de Justiça do Estado de São Paulo. Julgado em 13/12/10. Disponível em: <https://esaj.tjsp.jus.br/cjsg/getArquivo.do?cdAcordao=4868274\&vlCaptcha=Esxqv〉, acesso em 19 de dez. 2011.
} 
do Município de São Paulo e confirmadas pela Câmara Municipal. As rejeições ocorreram nos julgamentos relativos aos exercícios de 1999 e de 2000.

Em relação às contas de governo de 1999, o Tribunal de Contas do Município de São Paulo as rejeitou e tal decisão foi mantida pela Câmara Municipal.

Interessante, quanto a este caso, foi que o Vereador ${ }^{529}$ Wadih Jorge Mutran impetrou Mandado de Segurança contra o Presidente da Mesa da Câmara Municipal de São Paulo, alegando violação ao artigo 40 da Lei Orgânica do Município de São Paulo, que dispõe: “Art. 40. A discussão e votação de matéria constante da Ordem do Dia só poderá ser efetuada com a presença da maioria absoluta dos membros da Câmara"530 e ao artigo 47 da Constituição Federal, segundo o qual "Art. 47. Salvo disposição constitucional em contrário, as deliberações de cada Casa e de suas Comissões serão tomadas por maioria dos votos, presente a maioria absoluta de seus membros". 531

No caso concreto, qual seja, o julgamento das contas do Prefeito Celso Pitta, relativas ao exercício de 1999, estiveram presentes na sessão de julgamento quarenta e oito (dos cinquenta e cinco) vereadores, sendo que apenas vinte e seis confirmaram o parecer prévio elaborado pelo Tribunal de Contas e rejeitaram as contas de governo apresentadas pelo Prefeito. Não houve, assim, violação aos artigos 40 da Lei Orgânica do Município de São Paulo e 47 da Constituição Federal. Nas palavras do voto condutor:

\footnotetext{
${ }^{529}$ Consoante voto do Relator, Desembargador Ivan Sartori, o vereador tem legitimidade ativa para impetrar Mandado de Segurança em prol de um processo legislativo saudável. Eis uma das ementas do Supremo Tribunal Federal que, neste ponto, embasou a decisão do Desembargador Relator: EMENTA: CONSTITUCIONAL. PODER LEGISLATIVO: ATOS: CONTROLE JUDICIAL. MANDADO DE SEGURANÇA. PARLAMENTARES. I - O Supremo Tribunal Federal admite a legitimidade do parlamentar - e somente do parlamentar - para impetrar mandado de segurança com a finalidade de coibir atos praticados no processo de aprovação de lei ou emenda constitucional incompatíveis com disposições constitucionais que disciplinam o processo legislativo. II - Precedente do STF: MS 20.257/DF, Ministro Moreira Alves (leading caso) (RTJ 99/1031); (...)".Mandado de Segurança $\mathrm{n}^{\circ}$ 142.463-0/9-00, Rel. designado Desembargador Ivan Sartori. Órgão Especial do Tribunal de Justiça do Estado de São Paulo. Por maioria de votos, conheceram da impetração e, no mérito, por unanimidade, denegaram a ordem. Julgado em 26/09/07. Disponível em: $<$ https://esaj.tjsp.jus.br/cjsg/getArquivo.do?cdAcordao=2399320\&vlCaptcha=jdhnW>, acesso em 19 de dez. 2011.

${ }^{530}$ BRASIL. Lei Orgânica do Município de São Paulo: atualizada com a Emenda Constitucional no 28/2006. José Fernando Ferreira Brega (Org.). São Paulo: Páginas \& Letras Editora e Gráfica: Associação dos Procuradores do Município de São Paulo, 2006. p. 29.

${ }^{531}$ BRASIL. Constituição (1988). Constituição da República Federativa do Brasil: promulgada em 5 de outubro de 1988: atualizada até a Emenda Constitucional no 67, de 22-12-2010. 45 a ed. ampl. São Paulo: Saraiva, 2011. p. 55.
} 
"Assim, apesar de apenas vinte e seis edis terem se manifestado quando da apreciação do parecer do TCM rejeitando as contas referentes a 1999 do ex-Prefeito Celso Pitta, não se vê qualquer violação ao art. 40 da Lei Orgânica Local ou 47 da Constituição Federal, a preverem a presença da maioria absoluta dos membros à votação de matéria constante da ordem do dia, porquanto, como trás aludido, tal quorum já havia sido atingido". ${ }^{32}$

Alegou, ainda, o vereador Wadih Jorge Mutran, a violação ao princípio do contraditório e da ampla defesa, tese rechaçada pelo DD. Desembargador, tendo em vista que o então Prefeito teve assegurada a sua ampla defesa, tanto no Tribunal de Contas do Município de São Paulo quanto na Câmara Municipal.

No que tange às contas de governo do então Prefeito, relativas ao exercício de 2000, foram, igualmente, rejeitadas pelo Tribunal de Contas do Município de São Paulo. Dentre os fundamentos que embasaram a rejeição das contas destacam-se:

"DECIDE, à unanimidade, (...), emitir PARECER CONTRÁRIO à aprovação das Contas da Prefeitura do Município de São Paulo, relativas ao exercício de 2000, com fundamento nas irregularidades constatadas pelos Órgãos Técnicos, decorrentes do descumprimento das normas constitucionais e legais que disciplinam os orçamentos públicos, a saber:

5) Infringência ao artigo 70, inciso VII, da Lei Orgânica do Município, pelo não-repasse à Câmara Municipal dos duodécimos, nos prazos previstos;

(...)

7) Descumprimento do artigo 212 da Constituição Federal e também do artigo 60 do Ato das Disposições Constitucionais Transitórias, alterado pela Emenda 14, considerando que os percentuais mínimos das receitas resultantes de impostos não foram aplicados na manutenção $\mathrm{e}$ desenvolvimento do ensino;

8) Descumprimento do artigo 100 da Constituição Federal, pelo atraso nos pagamentos das obrigações constantes dos Mapas Orçamentários de Credores, pois remanescem direitos dos precatórios judiciais de 1997 em diante, e parte dos de 1996;

9) Descumprimento do artigo 42 da Lei de Responsabilidade Fiscal, pela realização de despesas e assunção de obrigações, nos dois últimos

\footnotetext{
532 Mandado de Segurança no 142.463-0/9-00, Rel. designado Desembargador Ivan Sartori. Órgão Especial do Tribunal de Justiça do Estado de São Paulo. Por maioria de votos, conheceram da impetração e, no mérito, por unanimidade, denegaram a ordem. Julgado em 26/09/07. Disponível em: <https://esaj.tjsp.jus.br/cjsg/getArquivo.do?cdAcordao=2399320\&vlCaptcha=jdhnW>, acesso em 19 de dez. 2011. Destaque-se que, no caso concreto, não se aplica o $\S 2^{\circ}$ do artigo 31 da Constituição Federal que exige o quorum de dois terços dos votos dos vereadores porque não se desejou derrubar o parecer prévio elaborado pelo Tribunal de Contas e sim mantê-lo. Assim, a manutenção do parecer prévio - no caso pela rejeição necessita, apenas, do voto da maioria simples, presente a maioria absoluta dos membros. Na sessão estiveram presentes quarenta e oito edis sendo preciso, nesta hipótese, apenas vinte e cinco votos (maioria simples) para o parecer prévio ser mantido, o que de fato ocorreu. Mantido o parecer prévio, as contas de governo do exercício de 1999 foram rejeitadas.
} 
quadrimestres do exercício, em montante superior às disponibilidades de caixa". 533

O parecer prévio foi encaminhado para votação na Câmara dos Vereadores. Os vereadores o confirmaram e rejeitaram as contas do Prefeito Celso Roberto Pitta do Nascimento.

Em seguida analisamos os pontos cruciais da tese.

\subsection{Há controle político quando o Tribunal de Contas elabora o parecer prévio apreciando as contas de governo apresentadas pelo Prefeito?}

Após o estudo das competências do Tribunal de Contas e da Câmara Municipal, o primeiro apreciando as contas de governo prestadas pelo Prefeito e o segundo julgando-as, impende, neste momento, responder a uma das perguntas que tem relação direta com a "novidade" de nossa tese: há controle político quando o Tribunal de Contas elabora o parecer prévio em cumprimento ao disposto no artigo 71, I, da Constituição Federal? Nosso desafio, neste tópico, é trazer a debate se a necessidade de oferecimento, pelo Prefeito, de suas contas para apreciação, primeiro, do Tribunal de Contas, com a consequente elaboração do parecer prévio, técnico e obrigatório e o posterior encaminhamento à Câmara Municipal, para que sejam julgadas, configura também um controle político por parte da Corte de Contas. E, em caso positivo, se o parecer prévio propondo a rejeição das contas é suficiente para causar a inelegibilidade do Prefeito.

A resposta é negativa para ambas as indagações. O Tribunal de Contas não realiza o controle político, matéria reservada ao povo que, nas eleições, aprova ou desaprova o governante nas urnas. É exercido, ainda, pelo Poder Legislativo, não obstante, atualmente, também seja ele realizado pelo Supremo Tribunal Federal, nos casos de "judicialização da política", matéria já estudada no item 1.4.3.1 (O fenômeno da “judicialização da política”)

\footnotetext{
${ }^{533}$ Balanço Geral ao Exercício de 2000, Prefeito Celso Roberto Pitta do Nascimento. Parecer Prévio nos autos do TC $\mathrm{n}^{\mathrm{o}}$ 72.001.839.01-83. Rel. Conselheiro Substituto Djalma Donato. Voto em separado proferido pelo Conselheiro Revisor, Antonio Carlos Caruso. Julgado em 24 de junho de 1992. V.u. contrário à aprovação das contas do Executivo. pp. 522-523.
} 
Sabemos que o controle político é uma das funções típicas do Poder Legislativo e que, quando o exerce, esse Poder atua como fiscal dos atos governamentais, acionando o sistema de checks and balances (ou controles recíprocos), que pregava Montesquieu.

É cediço, também, que o controle político é uma das formas de controle externo que o Poder Legislativo detém sobre os atos do Poder Executivo e que, em matéria orçamentária, se materializa, no caso em exame, pelo julgamento das contas de governo prestadas pelo Prefeito.

Ademais, a característica primordial do controle político é que, através dele, pode-se exigir a responsabilização política do mau detentor do Poder. Mas, em que consiste a responsabilidade política? Karl Loewenstein traz a resposta. Explica o autor:

\begin{abstract}
"Existe responsabilidade política quando um determinado detentor do poder tem que prestar contas ao outro detentor do poder sobre o cumprimento da função que lhe foi conferida, por exemplo, o governo ao parlamento, o parlamento ao governo e, em última instância, ambos ao eleitorado". ${ }^{534}$ (tradução nossa)
\end{abstract}

Anote-se que Karl Loewenstein, ao tratar da responsabilidade política na passagem acima, apontou somente para três ${ }^{535}$ dos detentores do Poder: o Governo, o Parlamento e o eleitorado. Qual a razão de ter excluído os Tribunais, que para o autor se configuram também como detentores do Poder? Pensamos que é porque foram relacionados somente os detentores que mantêm direta relação com o eleitorado e que dele dependem para continuar exercendo suas tarefas, ou seja, os representantes do Parlamento e do Poder Executivo, que são eleitos pelo povo, vez que o mesmo não ocorre com os membros do Poder Judiciário. Daí porque só é possível exigir a responsabilidade política destes dois detentores do Poder: Chefes do Executivo e membros do Parlamento, porque eles representam o povo e dependem da aprovação deste para continuar governando e

\footnotetext{
534 "Existe responsabilidad política cuando um determinado detentador del poder tiene que dar cuenta a outro detentador del poder sobre el cumplimiente de la función que le ha sido asignada, por ejemplo, el gobierno al parlamento, el parlamento al gobierno e, em último término, ambos al electorado". LOEWENSTEIN, Karl. Op. cit. p. 70. Consoante asseveramos, esta citação já foi utilizada no item 1.5.1.1(O Poder Legislativo e o controle político) quando tratávamos dos aspectos gerais da função de controle político na visão de Karl Loewenstein.

${ }_{535}$ Os detentores do poder, segundo Karl Loewenstein são: o Governo, o Parlamento, os Tribunais de Justiça e o eleitorado. Idem. p. 36.
} 
agindo em seu nome. É entre eles e o povo que se estabelece aquela "relação de confiança" que não deve ser quebrada.

Trazendo o modelo de Karl Loewenstein para o cenário pátrio, verifica-se que o Prefeito presta contas do uso do dinheiro público tanto à Câmara Municipal quanto ao próprio eleitorado. Se a primeira concluir pela má gestão dos recursos públicos, tratando-se de decisão irrecorrível da Casa das Leis e ficando comprovado que o Prefeito praticou "irregularidade insanável que configure ato doloso de improbidade administrativa", a consequência será a incidência da responsabilidade política e a inelegibilidade do Chefe do Executivo municipal por oito anos, em razão da aplicação do

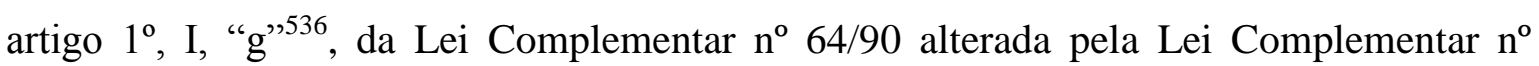
135/90, conhecida, esta última, como a Lei da "Ficha Limpa". Por outro lado, a responsabilidade política também poderá ser sentida nas urnas, não sendo o Prefeito reeleito ou eleito para outros cargos eletivos que vier a disputar, situação esta que, para o eleitorado, só se renova de quatro em quatro anos.

Tudo isto quer dizer que o controle político, essencial para a democracia, pertence ao povo. É ao povo que o Chefe do Executivo municipal presta contas, seja quando elas são avaliadas nas urnas, seja quando há o julgamento político na Câmara Municipal.

De se destacar, portanto, que a apresentação das contas de governo do Prefeito, primeiramente ao Tribunal de Contas, para que ele as aprecie e emita o parecer prévio, com o posterior encaminhamento para a Câmara dos Vereadores, não é suficiente para considerar a Corte de Contas como órgão que realiza o controle político.

O controle político é exclusivo do povo e é exercido nas urnas ou na Casa do Povo, que é a Câmara Municipal. O Tribunal de Contas não é composto por representantes do povo podendo, de imediato, ser rechaçada a hipótese de que realiza

\footnotetext{
${ }^{536}$ Art. $\mathbf{1}^{\mathbf{0}}$. São inelegíveis: I - para qualquer cargo: g) os que tiverem suas contas relativas ao exercício de cargos ou funções públicas rejeitadas por irregularidade insanável que configure ato doloso de improbidade administrativa, e por decisão irrecorrível do órgão competente, salvo se esta houver sido suspensa ou anulada pelo Poder Judiciário, para as eleições que se realizarem nos 8 (oito) anos seguintes, contados a partir da data da decisão, aplicando-se o disposto no inciso II do art. 71 da Constituição Federal, a todos os ordenadores de despesa, sem exclusão de mandatários que houverem agido nessa condição. BRASÍLIA (BR). Lei Complementar n ${ }^{\circ}$ 64, de 18 de maio de 1990, com redação dada pela Lei Complementar $\mathrm{n}^{\circ} 135$, de 4 de junho de 2010. Estabelece, de acordo com o art. 14, § $9^{\circ}$ da Constituição Federal, casos de inelegibilidade, prazos de cessação, e determina outras providências. Diário Oficial da União de 18 de maio de 1990.
} 
controle político. Não se estabelece, assim, a "relação de confiança" entre o povo e os Conselheiros do Tribunal de Contas, necessária para ensejar o controle político e provocar a incidência da responsabilidade política.

E, se o Tribunal de Contas não exerce controle político, o seu parecer prévio que opina pela rejeição das contas de governo prestadas pelo Prefeito não pode - sozinho - ter como consequência a responsabilidade política do mau gestor, vale dizer, somente o parecer prévio não é apto a causar a inelegibilidade do Chefe do Executivo municipal. Apenas a ratificação pela Câmara dos Vereadores, formada pelos representantes do povo, é que é capaz de levar à inelegibilidade do Prefeito.

Asseveramos, no entanto, que o Tribunal de Contas é órgão técnico responsável por elaborar o parecer prévio - técnico e obrigatório - que é enviado para o julgamento político da Câmara Municipal. As funções de cada qual são distintas, porém, complementares. Um realiza o controle técnico, o outro o político e ambos são essenciais para que o Prefeito tenha suas contas - e, pois, toda a sua gestão - aprovadas ou rejeitadas pela sociedade. É dizer, não se admite o julgamento político sem o parecer prévio do Tribunal de Contas e, de outro lado, somente este, como análise técnica, também não implica o julgamento definitivo das contas.

Significa então, que cada qual tem sua competência préestabelecida na aprovação das contas municipais: o Tribunal de Contas realizando a apreciação técnica e a Câmara Municipal procedendo ao julgamento político das contas. Um não pode interferir nas tarefas do outro, vale dizer, não se admite que o Tribunal de Contas realize julgamento político das contas, fugindo da apreciação técnica e, por outro lado, a Câmara Municipal não pode desconsiderar a análise técnica do Tribunal de Contas para proceder ao julgamento político.

Se o Tribunal de Contas se afastar da sua análise técnica, deixandose influenciar por aspectos políticos para a apreciação das contas, estará ocorrendo desvio de sua finalidade. Da mesma forma, no caso de a Câmara Municipal desconsiderar o parecer prévio elaborado pelo Tribunal de Contas ou decidir pela rejeição das contas por outros motivos, que não os contidos no parecer prévio da Corte de Contas, também estará causando desvio de finalidade, condutas estas repudiadas pelo Direito. 
A aprovação de contas funciona, repetimos, com o Tribunal de Contas procedendo à avaliação contábil, financeira, orçamentária, operacional e patrimonial das contas municipais - análise técnica - e a Câmara Municipal realizando o julgamento político, embasado no parecer prévio elaborado pelo primeiro.

Não obstante, é preciso concordar com Roberto Barcelos de Magalhães no sentido de que:

\footnotetext{
"Irrecusàvelmente, o Egrégio Tribunal de Contas, (...), tem, e não poderia deixar de ter certa função política, mas não no sentido da fiscalização política privativa do Congresso Nacional, pois a sua função é eminentemente técnica". ${ }^{537}$
}

Como se verifica, não se pode negar que o Tribunal de Contas, ao elaborar o parecer prévio, exerce "certa função política" como assevera o autor precitado. É que a aprovação das contas municipais requer a participação conjunta do Tribunal de Contas e da Câmara dos Vereadores, cada qual devendo desempenhar a sua função primordial. Ademais, esta "certa função política" ocorre somente porque estão sendo analisadas as contas de governo prestadas pelo Prefeito isto é, as contas de toda a sua gestão durante o ano e, por consequência, é a própria figura do Prefeito, eleito pelo povo, que estará sendo avaliada pelos eleitores. Contudo, isto não quer dizer que a Corte de Contas esteja realizando um controle político - que é exclusivo do povo e que se presta a analisar se o Prefeito fez, na visão do eleitorado, um bom ou mau governo -, já que o Tribunal de Contas efetua apenas um controle técnico sobre as contas municipais.

\subsection{A natureza da competência exercida pelo Tribunal de Contas e pela Câmara Municipal na aprovação das contas municipais}

Outra matéria que possui relação direta com a nossa tese e que se configura também como uma "novidade", diz respeito a saber qual a natureza da relação exercida pelo Tribunal de Contas e pela Câmara Municipal no que tange à aprovação das contas municipais de governo anualmente prestadas pelo Prefeito. De fato, quando a

\footnotetext{
${ }^{537}$ MAGALHÃES, Roberto Barcellos de. Op. cit. p. 216.
} 
Constituição Federal determina que o controle externo será exercido pelo Congresso Nacional com o "auxílio" 538 do Tribunal de Contas, o que isto quer dizer?

Para responder à pergunta, é preciso relembrar que já nos manifestamos entendendo que o Tribunal de Contas é um órgão constitucional autônomo $^{539}$ que encontra seu fundamento na Constituição, ou seja, sua criação e competências são fruto da vontade do Poder Constituinte, que também representa o povo. No que tange especificamente à competência para a apreciação das contas de governo prestadas pelo Prefeito, também afirmamos que ela deriva diretamente da Constituição Federal. Este fato - de ser órgão constitucional autônomo - exclui, pensamos, a possibilidade de considerar o Tribunal como um órgão subordinado ${ }^{540}$ ao Poder Legislativo.

Quer isto dizer que, de plano, eliminamos a possibilidade de entender o "auxílio" do Tribunal de Contas como subordinação ou dependência em relação ao Poder Legislativo. Aliás, se se tratasse de mera subordinação, não seriam necessários os dois terços dos votos dos membros da Câmara dos Vereadores para derrubar o parecer

\footnotetext{
${ }^{538}$ Dispõe o artigo 71, caput, da Constituição Federal de 1988: "Art. 71. O controle externo, a cargo do Congresso Nacional, será exercido com o auxílio do Tribunal de Contas da União, ao qual compete: (...)".BRASIL. Constituição (1988). Constituição da República Federativa do Brasil: promulgada em 5 de outubro de 1988: atualizada até a Emenda Constitucional n 67, de 22-12-2010. 45 a ed. ampl. São Paulo: Saraiva, 2011. p. 69.

${ }^{539}$ Para detalhes consultar o item 3.2 (A independência e a autonomia do Tribunal de Contas brasileiro).

${ }^{540}$ Ora, se o Tribunal de Contas fosse um órgão dependente do Poder Legislativo, jamais poderia julgar as contas de tal Poder. O próprio Supremo Tribunal Federal tem declarado inconstitucional artigo de Constituição Estadual que retira do Tribunal de Contas esta competência e o autoriza tão somente a elaborar parecer prévio sobre as contas do Poder Legislativo. É o que se observa na ementa da Ação Direta de Inconstitucionalidade $n^{\circ}$ 1964-3/Espírito Santo, Rel. Min. Sepúlveda Pertence: EMENTA: Tribunal de Contas dos Estados: competência: observância compulsória do modelo federal: inconstitucionalidade de subtração ao Tribunal de Contas da competência do julgamento das contas das Mesas das Câmaras Municipais - compreendidas na previsão do art. 71, II, da Constituição Federal, para submetê-las ao regime do art. 71, c/c art. 49, IX, que é exclusivo da prestação de contas do Chefe do Poder Executivo local (CF, art. $31, \S 2^{\circ}$ ); precedente (ADIn 849, 11.2.99, Pertence): suspensão cautelar parcial dos arts. $29, \S 2^{\circ} \mathrm{e}$ 71, I e II, da Constituição do Estado do Espírito Santo". (grifos nossos). Ação Direta de Inconstitucionalidade n ${ }^{\circ}$ 1964-3/Espírito Santo. Rel. Min. Sepúlveda Pertence. "Por maioria de votos, em deferir o pedido de medida cautelar, para suspender, até a decisão final da ação direta, a eficácia das expressões 'e o Presidente da Câmara', 'e pela Mesa da Assembléia Legislativa' e 'e Mesas das Câmaras Municipais', contidas, respectivamente, no $\S 2^{\circ}$ do art. 29 , no inciso I do art. 71 e no inciso II do mesmo artigo (71), todos da Constituição do Estado do Espírito Santo". Pleno. Julgado em 25/03/99. Publicado no Diário de Justiça de 07/05/99. Disponível em <http://redir.stf.jus.br/paginadorpub/paginador.jsp?docTP=AC\&docID=347354>, acesso em 22 de dez. 2011. Entendemos impossível considerar o Tribunal de Contas um órgão dependente do Poder Legislativo. Isto porque, se dependente fosse, não poderia julgar as contas do Poder Legislativo e, nos âmbitos federal e estaduais, não se admitiria julgar, ainda, as contas do Poder Judiciário e do Ministério Público, o que lhe é autorizado, de acordo com o disposto no artigo 71, II, da Constituição Federal.
} 
prévio do Tribunal de Contas, tal como determina o $\S 2^{\text {o541 }}$ do artigo 31 da Constituição Federal.

$$
\text { O "auxílio" existente pode, então, ser traduzido como uma }
$$

cooperação entre o Tribunal de Contas e a Câmara Municipal para a aprovação das contas municipais?

Cooperação existe, por exemplo, na elaboração da lei. É que ao Poder Legislativo compete todo o processo legislativo, entretanto, a lei somente começa a viger após ser sancionada pelo Chefe do Poder Executivo. Observa-se, neste caso, uma cooperação entre dois dos Poderes da República.

Também existe cooperação na relação entre o Poder Judiciário e o Ministério Público no tocante ao exercício da função jurisdicional. É o Ministro Carlos Ayres Britto quem explica tal relação:

“(...) não se pode exercer a jurisdição senão com a participação do Ministério Público. Senão com a obrigatória participação ou o compulsório auxílio do Ministério Público. Uma só função (a jurisdicional), com dois diferenciados órgãos a servi-la. Sem que se possa falar de superioridade de um perante o outro". ${ }^{442}$ (grifos nossos)

No mesmo sentido os ensinamentos de Adílson Abreu Dallari:

"Note-se que o Ministério Público não participa apenas da administração da Justiça, mas, sim, também, do próprio exercício da função jurisdicional. A Justiça não pode funcionar regularmente sem a atuação conjunta de juízes e promotores de justiça. A prestação jurisdicional requer, em muitos casos, a presença indispensável do Ministério Público". ${ }^{43}$

541 “Art. 32. (...). § $2^{\circ}$. O parecer prévio, emitido pelo órgão competente sobre as contas que o Prefeito deve anualmente prestar, só deixará de prevalecer por decisão de dois terços dos membros da Câmara Municipal”. BRASIL. Constituição (1988). Constituição da República Federativa do Brasil: promulgada em 5 de outubro de 1988: atualizada até a Emenda Constitucional no 67, de 22-12-2010. 45 a ed. ampl. São Paulo: Saraiva, 2011. p. 40.

542 BRITTO, Carlos Ayres. Op. cit. p. 62.

${ }^{543}$ DALLARI, Adílson Abreu. Op. cit. p. 31. 
Nesta hipótese há, igualmente, cooperação, porém, diferentemente da anterior, esta se estabelece entre um Poder - o Judiciário - e um órgão constitucional autônomo, que é o Ministério Público ${ }^{544}$.

Tal como os dois exemplos anteriormente citados - elaboração da lei e atividade jurisdicional desempenhada pelo Poder Judiciário e Ministério Público -, a relação existente entre o Tribunal de Contas e a Câmara Municipal para a aprovação das contas de governo anualmente prestadas pelo Prefeito é de verdadeira cooperação.

Karl Loewenstein ${ }^{545}$ também exemplifica a relação de cooperação. Assevera que ela ocorre na assinatura de um tratado internacional pelo Presidente da República que deve ser ratificada pelo Congresso Nacional. O autor dá este exemplo afirmando que "os detentores do poder podem estar de tal maneira organizados constitucionalmente que só conjuntamente podem realizar determinadas tarefas"546 (grifos e tradução nossos).

É bem verdade que os detentores do poder, para Karl Loewenstein são o Governo, o Parlamento, os Tribunais e o eleitorado, o que, a princípio, excluiria o Tribunal de Contas. Entendemos, entretanto, que a Corte de Contas possui características especiais que the permitem ser incluída na "ação conjunta" que aponta o autor. Ora, o Tribunal de Contas se apresenta como órgão constitucional autônomo, que decorre diretamente da Constituição e que exerce atividade de controle técnico que é somente dele. Funciona, então, como um órgão estatal de controle em relação aos Poderes e cuja existência é fundamental, pois "protege” as finanças públicas, evitando o seu desperdício e controlando o gestor do dinheiro público. Nesse sentido, assevera Hamilton Fernando Castardo:

"O Tribunal de Contas é uma instituição constitucional independente com missão de fiscalizar e verificar a boa aplicação do dinheiro público. É um

\footnotetext{
${ }^{544}$ Para detalhes de que o Ministério Público se apresenta como um órgão constitucional autônomo consultar Capítulo III.

${ }^{545}$ Nas palavras do autor: “(...) así, un tratado internacional solamente tendrá validez en los Estados Unidos cuando el Senado confirme la conclusión del acuerdo realizado anteriormente por el presidente. En este caso, los detentadores del poder tendrán que compartir constitucionalmente el ejercicio de la función, con lo cual se controlarán mutuamente". LOEWENSTEIN, Karl. Op. cit. p. 252.

${ }^{546}$ Idem. Ibidem.
} 
órgão integrante da pessoa jurídica da União, do estado ou do município que o tenha". ${ }^{447}$

E, mais adiante, continua o autor:

"O arquétipo constitucional determina que o Tribunal de Contas não integra a estrutura de nenhum dos poderes da União, mantendo-se como uma instituição independente, como órgão institucional autônomo. A razão da existência é a defesa dos interesses do cidadão e da sociedade, quanto à aplicação correta do dinheiro e a guarda e administração do patrimônio público". ${ }^{548}$ (grifos nossos)

No mesmo sentido o entendimento de Karl Loewenstein. É possível, então, retornar a uma das lições do referido autor, já explanada no item 1.5.1 (A função de controle inserida no processo do poder: a proposta de Karl Loewenstein), mas, naquela ocasião, restrita, a explicação, aos detentores do poder. Trataremos, agora, da distribuição do poder entre os órgãos estatais, da qual o Tribunal de Contas, por ser órgão constitucional autônomo, como anteriormente explicado, é exemplo. Aduz Karl Loewenstein:

"O Estado constitucional se fundamenta no princípio da distribuição do poder. A distribuição do poder existe quando vários e independentes detentores do poder ou órgãos estatais participam da formação da vontade estatal. As funções que lhes foram conferidas estão submetidas a um controle respectivo por meio dos outros detentores do poder. Pelo fato de estar distribuído, o exercício do poder está necessariamente controlado". ${ }^{549}$ (grifos e tradução nossos)

Podemos extrair, da explicação, que a distribuição do poder político também se apresenta entre os órgãos estatais - ou, como preferimos, órgãos constitucionais autônomos -, dos quais o Tribunal de Contas é exemplo.

\footnotetext{
${ }^{547}$ CASTARDO, Hamilton Fernando. Op. cit. p.63.

${ }^{548}$ Idem. p. 65.

549 “El Estado constitucional se basa en el principio de la distribución del poder. La distribución del poder existe cuando varios e independientes detentadores del poder u órganos estatales participan en la formación de la voluntad estatal. La s funciones que les han sido asignadas están sometidas a un respectivo control a través de los otros detentadores del poder; como está distribuido, el ejercicio del poder político está necesariamente controlado". LOEWENSTEIN, Karl. Op. cit. p. 50. Consoante asseveramos, esta citação já foi utilizada no item 1.5.1 (A função de controle inserida no processo do poder: a proposta de Karl Loewenstein), quando tratamos do conceito do Estado constitucional e dos detentores do poder. No momento presente objetivamos cuidar da distribuição do poder entre órgãos estatais.
} 
A distribuição do poder político se efetiva, no caso concreto, entre um Poder (o Legislativo) e um órgão constitucional autônomo (o Tribunal de Contas). Assim é que cada qual tem a sua função pré-estabelecida e não se admite, como asseveramos no tópico anterior, a interferência de um sobre o outro, sob pena de haver desvio de finalidade. Assim, ao Tribunal de Contas compete o exercício do controle técnico das contas de governo, controle este que se traduz nas fiscalizações contábil, financeira, orçamentária, operacional e patrimonial das contas, enquanto que à Câmara Municipal é reservado o controle político, que pode resultar, este último, na inelegibilidade do Prefeito.

Sobre a cooperação entre a Câmara Municipal e o Tribunal de Contas preleciona Diogo de Figueiredo Moreira Neto:

\begin{abstract}
"Como se pode observar, com a determinação de que o controle externo será exercido com o auxílio do Tribunal de Contas, já seria bastante esse caput para afastar a hipótese de existência de uma eventual margem discricionária para o Congresso Nacional vir a optar se aceita ou não a coadjuvação: muito ao contrário, o preceito torna inequivocamente obrigatória a cooperacão do Tribunal de Contas no exercício da função de controle externo". ${ }^{550}$ (grifos nossos)
\end{abstract}

De se observar, portanto, que a participação do Tribunal de Contas, referida no inciso I do artigo 71 da Constituição Federal não é dispensável, senão, obrigatória. Ou seja, o "auxílio" de que trata o inciso citado não se traduz em subordinação e sim em obrigatória cooperação.

E continua o autor, asseverando que duas conclusões podem ser extraídas desta relação:

\footnotetext{
"A primeira, de que a Constituição instituiu uma distinção estrutural de cunho político entre o Poder Legislativo e o Tribunal de Contas; e o fez, não só por estar a mencioná-los separadamente, o que seria um dado puramente formal, como, e principalmente, por que quis estabelecer entre ambos uma relação, que não sendo paritária nem, tampouco, de hierarquia ou de subordinação, só pode ser de cooperação, o que claramente se expressa na voz 'auxílio' (art. 71, caput).

Segundo, como o caput é genérico, e se refere irrestritamente a controle externo, deve-se concluir, a priori, que essa cooperação foi preconizada também genericamente, o que vale dizer que, embora não tendo toda a
}

\footnotetext{
${ }^{550}$ MOREIRA NETO, Diogo de Figueiredo. Op. cit. p. 108.
} 
amplitude prevista no art. 49, IX e X, da Constituição, e de aparecer limitada por um rol de atribuições específicas, (...) é inegável que a função de cooperação compartilha a mesma natureza política de controle exercido pelo órgão assistido." ${ }^{, 551}$ (grifos nossos)

A lição do autor precitado converge para a conclusão alcançada no tópico anterior: a de que o Tribunal de Contas, embora desempenhando atividade de controle técnico, pelo fato de cooperar com o Poder Legislativo através da elaboração do parecer prévio que será julgado politicamente na Câmara dos Vereadores, participa da função política reservada ao Poder Legislativo. Vale dizer, sua atividade não é de controle político, mas o Tribunal de Contas, através desta competência, exerce "certa função política".

Pelo exposto, defendemos que a aprovação das contas municipais se faz por meio de competência compartilhada entre ambos os órgãos. Assim, o controle técnico do Tribunal de Contas, ao apreciar as contas de governo prestadas pelo Prefeito elaborando um parecer prévio, é condição sine qua non para o controle político a ser realizado pela Câmara Municipal quando julgar tais contas, não se admitindo este sem aquele, exercido no âmbito da fiscalização contábil, financeira, orçamentária, operacional e patrimonial.

E, ainda, afirmamos que tal competência compartilhada é indispensável no Estado Constitucional. Respeitando-se este regramento de competência compartilhada, o poder político se apresenta distribuído e limitado entre um Poder e um órgão constitucional autônomo, parâmetros essenciais em um Estado Democrático.

\subsection{Os efeitos da atuação do Tribunal de Contas no âmbito municipal}

Objetivamos, neste momento, explicar os efeitos da atuação do Tribunal de Contas no âmbito municipal.

Por tudo o que já foi exposto, não há dúvidas de que a presença do Tribunal de Contas no cenário pátrio é importante para que as contas públicas municipais possam ser devidamente fiscalizadas.

${ }^{551}$ Idem. pp. 108-109. 
É que o Tribunal de Contas é o órgão constitucional autônomo que possui a responsabilidade de realizar o controle técnico sobre as contas, ou seja, o controle sob os aspectos das fiscalizações contábil, financeira, orçamentária, operacional e patrimonial das contas públicas.

Para bem desempenhar o seu mister constitucional de controle técnico, é preciso que o Tribunal de Contas seja formado por um corpo de especialistas. Assim é que há, dentre os auditores da Corte de Contas, engenheiros, contadores, administradores, advogados e economistas.

Por outro lado, no que tange ao seu corpo diretivo, devem os Conselheiros, dentre outros requisitos, apresentar "notórios conhecimentos jurídicos, contábeis, econômicos e financeiros ou de administração pública", tal como requer o inciso III $^{552}$ do parágrafo único do artigo 49 da Lei Orgânica do Município de São Paulo.

Mas, qual a finalidade da existência de um órgão altamente especializado no controle das contas municiais?

A resposta, pensamos, é encontrada nos princípios democrático $e$ republicano. No primeiro, porque os atos do gestor público devem ser dotados de transparência, daí porque deve ele prestar contas do uso dos recursos públicos ao verdadeiro destinatário do poder, que é o povo. No segundo, em razão de o detentor do poder nada mais ser do que mero administrador da res publica pertencente ao povo e, assim, quem apenas administra os bens de outrem deve prestar-lhe contas.

A sistemática constitucional existente determina, pois, que o gestor público preste contas. Nessa senda, o Prefeito ${ }^{553}$ deve prestá-las à Câmara Municipal, à qual compete o julgamento das contas de governo. Fá-lo, entretanto, ao órgão

${ }^{552}$ BRASIL. Lei Orgânica do Município de São Paulo: atualizada com a Emenda Constitucional nº 28/2006. José Fernando Ferreira Brega (Org.). São Paulo: Páginas \& Letras Editora e Gráfica: Associação dos Procuradores do Município de São Paulo, 2006. p. 41.

${ }^{553}$ Dispõe o artigo 71, I, da Constituição Federal: “Art. 71, I. (...). I - apreciar as contas prestadas anualmente pelo Presidente da República, mediante parecer prévio que deverá ser elaborado em sessenta dias a contar de seu recebimento". BRASIL. Constituição (1988). Constituição da República Federativa do Brasil: promulgada em 5 de outubro de 1988: atualizada até a Emenda Constitucional no 67, de 22-12-2010. $45^{\mathrm{a}}$ ed. ampl. São Paulo: Saraiva, 2011. p. 69. Por simetria constitucional, o inciso I do artigo 48 d Lei Orgânica do Município de São Paulo dispõe: “Art. 48. (...) I - apreciar as contas prestadas anualmente pelo Prefeito, pela Mesa da Câmara e pelo próprio Tribunal, mediante parecer prévio que deverá ser elaborado em 90 (noventa) dias, a contar da data de seu recebimento, que terá seu termo final em 31 de março de cada exercício". BRASIL. Lei Orgânica do Município de São Paulo: atualizada com a Emenda Constitucional no 28/2006. José Fernando Ferreira Brega (Org.). São Paulo: Páginas \& Letras Editora e Gráfica: Associação dos Procuradores do Município de São Paulo, 2006. p. 37. 
intermediário, que é o Tribunal de Contas. Por sua vez, os demais administradores públicos prestam contas diretamente ao Tribunal de Contas, na exegese no inciso II $^{554}$ do artigo 71 da Constituição Federal.

No que tange ao Prefeito, deve ele, anualmente, e no prazo de sessenta dias, encaminhar as contas de governo para a apreciação do Tribunal de Contas, ao qual competem, como já amplamente explanado, as fiscalizações contábil, financeira, orçamentária, operacional e patrimonial das contas municipais. Exerce este, portanto, as atribuições de controle externo juntamente com o Poder Legislativo. Recebidas as contas, tem o Tribunal de Contas, também, o dever de apreciá-las, no Município de São Paulo, no prazo de noventa dias ${ }^{55}$, mediante a elaboração de um parecer prévio, com o seu posterior encaminhamento à Câmara Municipal, onde se processará o julgamento político dessas contas de governo.

O parecer prévio, peça técnica e obrigatória, tem especial relevância no âmbito municipal, pois a disposição do $\S 2^{\circ}$ do artigo 31 da Constituição Federal, diferentemente do que ocorre nos âmbitos federal e estaduais, determina que ele só deixará de prevalecer pelo voto de dois terços dos membros da Câmara Municipal. Este fato - a exigência de maioria qualificada - para derrubar o parecer prévio do Tribunal de Contas é suficiente para, em nosso entendimento, não admitir que se considere o parecer prévio como peça meramente opinativa. Hely Lopes Meirelles, contrapondo-se também ao entendimento de o parecer prévio ser meramente opinativo assevera:

“Criou-se, assim, para as contas municipais, um sistema misto em
que o 'parecer prévio' do Tribunal de Contas ou do órgão
equivalente é 'vinculante' para a Câmara dos Vereadores até que a
votação contra esse mesmo parecer atinja dois terços de seus
membros, passando, daí por diante, a ser meramente opinativo e
rejeitável pela maioria qualificada do Plenário. Portanto, o 'parecer'
do Tribunal ou órgão de contas vale como 'decisão' enquanto a Câmara

${ }^{554}$ Dispõe o artigo 71, II, da Constituição Federal: “Art. 71. (...). II - julgar as contas dos administradores e demais responsáveis por dinheiros, bens e valores públicos da administração direta e indireta, incluídas as fundações e sociedades instituídas e mantidas pelo Poder Público federal, e as contas daqueles que derem causa a perda, extravio ou outra irregularidade de que resulte prejuízo ao erário público". BRASIL. Constituição (1988). Constituição da República Federativa do Brasil: promulgada em 5 de outubro de 1988: atualizada até a Emenda Constitucional no 67, de 22-12-2010. 45 ed. ampl. São Paulo: Saraiva, 2011. p. 70.

${ }^{555}$ Consoante artigo 48, I, da Lei Orgânica do Município de São Paulo, anteriormente citado. 
não o substituir por seu 'julgamento' qualificado pelo 'quorum' constitucional". ${ }^{556}$ (grifos nossos)

Importantes os ensinamentos do autor. Entende que o parecer prévio do Tribunal de Contas e o julgamento das contas pela Câmara Municipal compõem um sistema misto em que o parecer prévio (técnico) prevalece enquanto não houver o julgamento (político) pela Câmara Municipal e que, após o julgamento, se forem obtidos os dois terços constitucionais, o parecer se torna meramente opinativo.

Pedimos vênia para tecer alguns comentários sobre o posicionamento do autor. Parece-nos que o que o fez "criar" esta sistemática consistente em o parecer prévio prevalecer enquanto não houver julgamento pela Câmara dos Vereadores foi exatamente uma tentativa de exigir que a Câmara exerça sua competência julgadora, já que o ordenamento constitucional não traz expressamente tal obrigatoriedade no artigo 31 .

Já tivemos a oportunidade de explicar nos itens 4.3.1.2 (A função de controle político) e 5.4 (Há controle político quando o Tribunal de Contas elabora o parecer prévio apreciando as contas de governo apresentadas pelo Prefeito?) que a responsabilidade política processa-se perante o povo, que exerce o seu direito diretamente nas urnas ou por meio de seus representantes eleitos, isto é, no caso em pauta, pela Câmara Municipal. Assim, ainda que o parecer prévio opine pela rejeição das contas do Prefeito, somente ele não tem o condão de causar a inelegibilidade do administrador público. $\mathrm{O}$ Prefeito tem o direito de ser julgado pela Câmara Municipal e somente ela (ou as urnas) poderá levar à sua inelegibilidade. Ora, se o parecer prévio vinculasse, deveria ser capaz de impor a responsabilidade política ao mau gestor público, o que, em nosso entendimento, não se admite.

Posicionamento diverso quanto à responsabilidade política é o encontrado no inciso II do artigo 71 da Constituição Federal de 1988. Neste caso, o julgamento das contas dos demais administradores públicos - à exceção do Prefeito -, é realizado pelo Tribunal de Contas (como decisão final e não intermediária) sendo, pois, capaz de gerar a inelegibilidade do gestor público.

${ }^{556}$ MEIRELLES, Hely Lopes. Direito administrativo... Op. cit. p. 701. 
Por outro lado, a Constituição Federal de 1988 confere, ainda, aos Conselheiros do Tribunal de Contas, as mesmas garantias e independência que as relativas ao Poder Judiciário, isto é, autoriza-os, no que couber, a exercer as atribuições do artigo $96^{557}$ da Lei Maior e assim o faz para que o Tribunal de Contas não seja dependente de nenhum outro órgão ou Poder, tendo condições de tomar as suas próprias decisões relativas ao controle técnico - de maneira autônoma.

Destacamos, também, que a Constituição Federal de 1988 alargou as competências da Corte de Contas, conferindo-lhe posição ativa no controle das contas. Citamos como exemplo a realização de auditorias, por iniciativa própria, a serem efetuadas tanto nas unidades administrativas do Poder Executivo, como nas do Poder Legislativo e nos entes despersonalizados.

De tudo o que foi exposto concluímos que o denominado "auxílio" prestado pelo Tribunal de Contas no desempenho da função de controle externo é imprescindível para que as contas do Prefeito sejam julgadas daí porque, mais uma vez, afirmamos que a relação existente entre a Corte de Contas e a Câmara Municipal é de verdadeira cooperação, compartilhadas as suas competências na aprovação das contas municipais.

Sobre o tema, pensamos como o insigne Ministro Carlos Ayres Britto, cuja lição tem o seguinte teor:

\begin{abstract}
"Por este modo de ver as coisas, avulta a indispensabilidade ou a rigorosa essencialidade do papel institucional das Cortes de Cotnas. De uma parte, não é o Tribunal de Contas da União um aparelho que se acantone na intimidade estrutural do Congresso Nacional. De outra banda, não opera essa mesma Corte de Contas como órgão meramente auxiliar do Congresso Nacional. Sua atuação jurídica se dá a latere do congresso, junto dele, mas não do lado de dentro". ${ }^{558}$
\end{abstract}

Todos estes motivos demonstram a relevância da instituição do Tribunal de Contas no cenário do controle das contas municipais.

\footnotetext{
${ }^{557}$ Dentre as competências privativas conferidas aos Tribunais estão: eleger o seu corpo diretivo e elaborar o seu regimento interno; organizar suas secretarias e serviços auxiliares; realizar concursos públicos de provas ou de provas e títulos para prover os cargos necessários do Tribunal de Contas. Para detalhes, consultar: Artigo 96 da Constituição Federal de 1988. BRASIL. Constituição (1988). Constituição da República Federativa do Brasil: promulgada em 5 de outubro de 1988: atualizada até a Emenda Constitucional $\mathrm{n}^{\circ}$ 67, de 22-12-2010. $45^{\mathrm{a}}$ ed. ampl. São Paulo: Saraiva, 2011. p. 82.

${ }^{558}$ BRITTO, Carlos Ayres. Op. cit. p. 65.
} 


\section{CONCLUSÕES}

1.

Dentre as funções típicas atribuídas ao Poder Legislativo, ganha destaque, para o estudo do tema - "O controle das contas municipais" -, a de controle.

Por meio dela o Poder Legislativo desenvolve o controle financeiro e o controle político, o que lhe permite ocupar, novamente, posição de destaque no cenário mundial, posição esta que, no inicio do século XX, após a Primeira Guerra Mundial, havia perdido para o Poder Executivo, em razão da proliferação do Welfare State (o Estado de Bem-Estar Social), que exigia a presença ativa do Presidente da República a executar as políticas públicas para a classe social mais carente.

No final do século XX teve início, novamente, uma fase áurea para o Poder Legislativo, em razão do crescimento de sua função típica de controle.

Consoante já asseverado ao longo deste trabalho, pelo controle financeiro atribui-se ao Poder Legislativo uma função investigatória ${ }^{559}$, conferindo-lhe a atribuição de controlar os gastos públicos praticados pelo Governo, tarefa esta que se desenvolve com o "auxílio" de um órgão técnico, que é o Tribunal de Contas.

A função de controle político, por sua vez, em matéria orçamentária e considerando-se o direito pátrio, significa conceder ao Poder Legislativo a função de fiscal dos atos praticados pelo Poder Executivo. Quer dizer que compete ao Poder Legislativo aprovar a lei orçamentária e as respectivas emendas, interferindo diretamente nas políticas públicas que serão adotadas pelo Chefe do Poder Executivo, cabendo-lhe exclusivamente julgar as contas de governo anualmente prestadas por este.

Além disso, o julgamento das contas do Prefeito torna possível exigir a responsabilidade política do mau gestor público, que pode culminar, inclusive, com a sua inelegibilidade por oito anos, fazendo incidir, nessa hipótese, o artigo 1 ${ }^{\circ}$, I, "g",

559 É Monica Herman Salem Caggiano que explica em que consiste esta "função investigatória". Aduz a autora: "No mundo contemporâneo, contudo, a ênfase do poder financeiro dos Parlamentos incide, na realidade, sobre a sua vertente investigatória - o seu papel de verdadeiro vigilante -, tarefa que o Legislativo desempenha com o auxílio de sistemas técnicos, desenvolvidos com o escopo de lhe assegurar mecanismos a melhor acompanhar todo o processo de execução orçamentária, viabilizando a adequada análise das receitas e das despesas, do ponto de vista da legalidade e da finalidade perseguida". (grifos nossos). CAGGIANO, Monica Herman Salem. Direito... Op. cit. p. 23. 
da Lei Complementar $n^{\circ}$ 64/90, com a redação dada pela Lei Complementar $n^{\circ}$ 135/10, conhecida como a Lei da "Ficha Limpa".

Verifica-se, pois, que, por meio destas duas funções de controle do Poder Legislativo - controle financeiro e controle político - o sistema de "checks and balances" (ou freios e contrapesos), teorizado por Montesquieu, é acionado, de tal sorte que o Poder Legislativo controle os recursos orçamentários aplicados pelo Poder Executivo, estabelecendo-se condições de convivência harmônica entre os Poderes envolvidos.

Surgem, no entanto, questões que já foram objeto de nossas explanações em linhas gerais no item 4.3.1.2 (A função de controle político) e que merecem análise pormenorizada neste momento.

Lá, indagávamos qual seria o papel do Poder Legislativo na função de controle, levando em consideração, como nos apontou Odete Medauar ${ }^{560}$, que tal Poder não tinha "interesse político" em desagradar o Executivo, mais forte e hegemônico e, ainda, que inexistem sanções para o caso de o Poder Legislativo não cumprir o seu mister constitucional de proceder ao controle político - no caso específico - julgando as contas públicas municipais.

Naquela oportunidade aduzimos - e agora reafirmamos - que o papel do Poder Legislativo é o de efetivamente controlar o Executivo, eis que este é a essência do controle político: delimitar, vigiar, monitorar, de forma contínua, as ações do Poder Executivo. Não pode o Legislativo fugir desta atribuição, sob pena de os checks and balances, tão essenciais à preservação da teoria da separação de Poderes, serem maculados. É dizer, o princípio só terá sua plena eficácia se cada Poder atender às suas funções típicas, bem como às funções relativas aos controles recíprocos que um Poder exerce sobre o outro. No nosso caso compete, portanto, à Câmara Municipal fiscalizar, monitorar, vigiar os gastos públicos do Poder Executivo, responsabilizando, se for o caso, o Prefeito por sua má gestão.

Mais ainda. É preciso que a responsabilidade política, ao invés de ficar "esquecida", possa incidir em relação aos atos praticados e, nesse sentido, torna-se

${ }_{560}^{5}$ MEDAUAR, Odete. Controle da administração pública. São Paulo: Revista dos Tribunais, 1993. pp. 9091. 
imprescindível que a Câmara Municipal proceda ao julgamento das contas de governo apresentadas pelo Prefeito, mesmo que o processo culmine com a aprovação de tais contas. O que não se admite é privar o povo - porque ele é o destinatário final do poder - do direito de ver as contas do Chefe do Executivo julgadas pela Câmara dos Vereadores e, se for o caso, como consequência, atribuindo ao gestor a responsabilidade política e tornando o Prefeito inelegível.

A título de exemplo, destacamos que no Município de São Paulo, sob a égide da Constituição de 1988, todas as contas de governo prestadas pelos Prefeitos até o ano de 2007 já foram julgadas pela Câmara Municipal, tendo sido rejeitadas apenas três: uma da ex-Prefeita Luíza Erundina, de 1991 e duas do ex-Prefeito Celso Roberto Pitta do Nascimento, relativas aos anos de 1999 e 2000. Além disso, as contas referentes aos exercícios de 2008, 2009 e 2010 estão na pauta para julgamento do dia 13 de dezembro de 2011. No Município Paulistano pode-se afirmar, portanto, que a Câmara Municipal vem cumprindo seus deveres relacionados aos freios e contrapesos, já que está procedendo ao julgamento político das contas de governo. Não é esta, no entanto, a realidade de muitos Municípios brasileiros.

Outras perguntas, também por nós elaboradas no mesmo item 4.3.1.2 (A função de controle político), dizem respeito à necessidade ou não da existência de sanções aplicadas ao Legislativo no caso de não cumprimento de sua função constitucional de controle político. No nosso caso, significa indagar se é possível exigir da Câmara dos Vereadores o julgamento das contas municipais. Estas questões serão objeto de tratamento detalhado no item 5 destas Conclusões, quando cuidarmos da necessidade de fixação de prazo para a Câmara Municipal julgar as contas de governo anualmente prestadas pelo Prefeito.

2.

Passemos, agora, à análise do controle externo.

Controle externo é o controle realizado por um órgão diferente daquele onde o controle será exercido. Em matéria orçamentária, quer dizer o controle que a Câmara Municipal exerce sobre o uso que o Prefeito confere ao dinheiro público. A realização da tarefa é, no entanto, desempenhada com o auxílio do Tribunal de Contas. É isto que determinam os artigos 70, caput e 71, caput, da Constituição Federal que estabelecem: 
“Art. 70. A fiscalização contábil, financeira, orçamentária, operacional e patrimonial da União e das entidades da administração direta e indireta, quanto à legalidade, legitimidade, economicidade, aplicação das subvenções e renúncia de receitas, será exercida pelo Congresso Nacional, mediante controle externo, e pelo sistema de controle interno de cada Poder". ${ }^{561}$ (grifos nossos)

"Art. 71. O controle externo, a cargo do Congresso Nacional, será exercido com o auxílio do Tribunal de Contas da União, ao qual compete: (...)". ${ }^{562}$ (grifos nossos).

Pedimos vênia, no entanto, para discordar das afirmações colocadas nesses dispositivos. Não que com isso queiramos dizer que as normas constitucionais contidas nos artigos 70, caput e 71, caput, são inconstitucionais. Apenas propomos outra interpretação para os dispositivos mencionados.

Em nosso entendimento, a melhor interpretação seria a de que a tarefa de controle externo é conferida à Câmara Municipal e ao Tribunal de Contas. Isto porque, partindo, novamente, do conceito de controle externo - o realizado por órgão diferente daquele onde o controle será exercido - pensamos que ela "se encaixa" perfeitamente na relação que ocorre entre o Tribunal de Contas e a prestação das contas de governo feitas pelo Prefeito. É dizer, o Tribunal de Contas, ao elaborar o parecer prévio sobre as contas de governo prestadas pelo Prefeito controla (externamente) o uso que o Prefeito confere ao dinheiro público, da mesma forma que a Câmara dos Vereadores, quando procede ao julgamento das contas. A diferença, neste aspecto, encontra-se na maneira como cada qual desempenha sua competência: o Tribunal de Contas elaborando parecer prévio, técnico e obrigatório, que contém a apreciação das contas de governo do Prefeito e a Câmara Municipal, julgando-as.

Assim, embora esteja o Tribunal de Contas inserido na Seção IX (“Da Fiscalização Contábil, Financeira e Orçamentária”), do Capítulo I ("Do Poder Legislativo"), do Título IV ("Da Organização dos Poderes”), podendo dar a falsa impressão de que é um órgão dependente do Poder Legislativo, pensamos que a melhor técnica legislativa seria reservar-lhe um Capítulo específico dentro do mesmo Título IV,

\footnotetext{
561 BRASIL. Constituição (1988). Constituição da República Federativa do Brasil: promulgada em 5 de outubro de 1988: atualizada até a Emenda Constitucional no 67, de 22-12-2010. 45 a ed. ampl. São Paulo: Saraiva, 2011. p. 69.

562 BRASIL. Constituição (1988). Constituição da República Federativa do Brasil: promulgada em 5 de outubro de 1988: atualizada até a Emenda Constitucional no 67, de 22-12-2010. $45^{\mathrm{a}}$ ed. ampl. São Paulo: Saraiva, 2011. p. 69.
} 
denominado, por exemplo, como "Dos Órgãos de Cooperação", na medida em que não há dúvidas de que a competência que desempenha - fiscalização contábil, financeira, orçamentária, operacional e patrimonial das contas públicas - consiste, também, em controle externo. Com esta medida eliminar-se-iam as divergências doutrinárias acerca de considerar o Tribunal de Contas como um órgão constitucional autônomo ou como um órgão dependente. Como órgão constitucional autônomo exerce, o Tribunal de Contas, a função de controle externo das contas de governo prestadas pelo Prefeito, tal qual o Poder Legislativo.

Reforçam nosso entendimento as palavras do Ministro Carlos Ayres Britto, do Supremo Tribunal Federal, em que pese entenda o autor que o controle externo pertence ao Poder Legislativo e é executado por este e pelo Tribunal de Contas:

"No âmbito da função legislativa, que é a função mais típica do
Parlamento ou a função que empresta seu nome ao Poder que dela se
encarrega, o prestígio que a Lei Maior confere ao Parlamento mesmo é o
maior possível: ele é quem dá a última palavra a respeito de todo e
qualquer ato legislativo (mesmo quando se trate da edição de "medidas
provisórias"). Mas não é assim que ocorre no círculo da função de
controle externo, pois algumas atividades de controle nascem e
morrem do lado de fora das Casas Legislativas. A partir da
consideração de que as próprias unidades administrativas do Poder
Legislativo Federal são fiscalizadas é pelo Tribunal de Contas da União
(inciso IV do art. 71 da CF)". ${ }^{563}$ (grifos nossos) Continua o Ministro asseverando que estão sob o crivo do Poder Legislativo julgar as contas do Chefe do Poder Executivo e fiscalizar e controlar os atos do Poder Executivo, incluídos os da administração indireta, de acordo com o que dispõem os incisos IX e X do artigo 49 da Constituição Federal.

Verifica-se, então, que todos os outros atos, insertos nos incisos II a XI do artigo 71 da Constituição Federal, são de competência exclusiva do Tribunal de Contas. A única exceção é a do inciso I - apreciar as contas de governo do Prefeito -, cuja competência é exclusiva do Tribunal de Contas, porém, o seu julgamento final depende da manifestação da Câmara Municipal.

3. Outro ponto que merece destaque é que o Tribunal de Contas tem a natureza, para nós, de órgão constitucional autônomo. Esta afirmação é corroborada pelo

${ }^{563}$ BRITTO, Carlos Ayres. Op. cit. p. 63. 
posicionamento consistente em a Corte de Contas receber tratamento diferenciado do conferido ao Poder Legislativo. Ademais, tal órgão não pertence à estrutura de nenhum dos Poderes. E, ainda, encontra toda a sua fundamentação, exceto uma ${ }^{564}$, na Constituição Federal, isto é, deriva diretamente da Lei Maior, o que o coloca ao lado dos Poderes Executivo, Legislativo e Judiciário, que também emanam diretamente da Constituição Federal. Pode-se dizer, então, como fez o Ministro Carlos Ayres Britto, do Supremo Tribunal Federal, que o Tribunal de Contas se encontra "a latere" do Poder Legislativo. Nas palavras do Ministro: "Sua atuação jurídica [do Tribunal de Contas] se dá 'a latere' do Congresso, junto dele, mas não do lado de dentro". 565

Além disso, considerar o Tribunal de Contas como órgão constitucional autônomo, com as características anteriormente descritas, nos leva a crer que o "auxílio" exposto no artigo 71 da Constituição Federal nada mais quer dizer do que cooperação. Auxílio não é, pois, dependência, subordinação ou atuação secundária do Tribunal de Contas. Aliás, se assim fosse, qual seria a razão de a Constituição Federal exigir a maioria qualificada de dois terços dos votos dos membros da Câmara Municipal para derrubar o parecer prévio elaborado pelo Tribunal de Contas relativo à apreciação das contas de governo prestadas pelo Prefeito? Auxílio, na espécie, traduz-se como cooperação e, pois, como soma, possuindo, Tribunal de Contas e Câmara Municipal, competências distintas, porém complementares na aprovação das contas municipais. Ao Tribunal de Contas compete o controle técnico e à Câmara dos Vereadores o julgamento político.

4.

Analisemos, neste momento, a questão referente à proibição constitucional para a criação de novos Tribunais de Contas no âmbito dos Municípios. Quanto a este tema, verificamos que a Constituição Federal de 1988 prestigiou os Municípios quando os alçou a entes federativos, dotando-os de autonomia. Contudo,

\footnotetext{
${ }^{564}$ Trata-se da competência relativa à aplicação das sanções, que depende de lei. De acordo com o inciso VIII do artigo 71 da Constituição Federal: "aplicar aos responsáveis, em caso de ilegalidade de despesa ou irregularidade de contas, as sanções previstas em lei, que estabelecerá, entre outras cominações, multa proporcional ao dano causado ao erário". (grifos nossos). BRASIL. Constituição (1988). Constituição da República Federativa do Brasil: promulgada em 5 de outubro de 1988: atualizada até a Emenda Constitucional n ${ }^{\circ}$ 67, de 22-12-2010. $45^{\text {a }}$ ed. ampl. São Paulo: Saraiva, 2011. p. 70.

${ }^{565}$ BRITTO, Carlos Ayres. Op. cit. p. 65
} 
contrapondo-se à autonomia referida, vedou a criação de Tribunais, Conselhos ou órgãos de Contas Municipais, na exegese do $\S 4^{\text {o566 }}$ do artigo 31.

Verifica-se que a vedação é somente para a criação de Tribunais ou Conselhos de Contas 'Municipais. Não para os órgãos estaduais. Isto é, o ordenamento vigente não admite a criação de Tribunal de Contas do Município além dos dois já existentes, que são os de São Paulo e do Rio de Janeiro. Ressalte-se que estes Tribunais analisam as contas municipais somente das Capitais dos Estados a que se referem. Não veda, a Constituição Federal, no entanto, a criação de novos Tribunais de Contas dos Municípios, além dos já existentes na Bahia, no Ceará, em Goiás e no Pará, que são órgãos estaduais, mas que examinam as contas dos Municípios localizados nestes Estados, e nem a criação de Tribunais de Contas Estaduais, que se prestam ao exame das contas dos demais Municípios, excluídos os já citados.

Defendemos, entretanto, ser uma injustiça constitucional a proibição à criação de novos Tribunais de Contas no âmbito dos Municípios, Tribunais estes, repita-se, municipais e destinados a analisar as contas dos Municípios a que se refiram. Isto porque, conforme já expusemos, o Tribunal de Contas figura como um órgão constitucional autônomo, que encontra o seu fundamento de validade na Constituição, de onde retira sua importância. Além disso, consoante explicado no item 3.2 (A independência e a autonomia do Tribunal de Contas brasileiro) e no item 4.4.2 (A vedação constitucional para a criação de novos Tribunais, Conselhos ou órgãos de Contas Municipais), entendemos que a existência de Tribunais de Contas nas esferas municipais reforçaria a autonomia dos Municípios.

Permitimo-nos indagar, por pertinente, o motivo pelo qual os Municípios de Belo Horizonte ou de Porto Alegre, por exemplo, Capitais de seus Estados, com elevados contingentes populacionais e orçamentos de monta, não possuem um Tribunal de Contas próprio. Manoel Gonçalves Ferreira Filho já asseverou e nós apontamos no item 4.4.2 (A vedação constitucional para a criação de novos Tribunais, Conselhos ou órgãos de Contas Municipais), que "as contas dos administradores dos Municípios de grande arrecadação seriam mais atentamente examinadas por tribunal

566 “Art. 31. (...). § $4^{\circ}$. É vedada a criação de Tribunais, Conselhos ou órgãos de Contas Municipais". BRASIL. Constituição (1988). Constituição da República Federativa do Brasil: promulgada em 5 de outubro de 1988: atualizada até a Emenda Constitucional no 67, de 22-12-2010. 45 a ed. ampl. São Paulo: Saraiva, 2011. p. 40. 
próprio (...) ${ }^{, 567}$, realçando que os Municípios mais ricos poderiam arcar com as despesas para a instalação e manutenção dos próprios Tribunais de Contas.

Assim, o primeiro critério que nos parece razoável para a criação de novos Tribunais de Contas nos Municípios, nos moldes dos existentes em São Paulo e no Rio de Janeiro, seria o fato de o Município ser Capital do Estado. E isto em razão da importância que as Capitais representam para os seus Estados. Tal critério, aliás, respeitaria o pacto federativo brasileiro.

Não se admitiria, assim, que o Município de Rio Branco, que, segundo o Censo de $2010^{568}$ tem 336.038 (trezentos e trinta e seis mil e trinta e oito) habitantes e receita orçamentária ${ }^{569}$, esta referente a 2009, de $\mathrm{R} \$ 430.724 .905,73$ (quatrocentos e trinta milhões, setecentos e vinte e quatro mil e novecentos e cinco reais e setenta e três centavos); ou que Macapá, com 398.204 (trezentos e noventa e oito mil e duzentos e quatro) habitantes, com receita orçamentária de $\mathrm{R} \$ 358.897 .740,78$ (trezentos e cinquenta e oito milhões, oitocentos e noventa e sete mil e setecentos e quarenta reais e setenta e oito centavos) não fossem providos de Tribunais de Contas próprios, somente porque sua população e receita orçamentária são menores que as de Porto Alegre, com 10.693.929 (dez milhões, seiscentos e noventa e três mil e novecentos e vinte e nove) habitantes e receita realizada de $\mathrm{R} \$ 3.122 .661 .659,68$ (três bilhões, cento e vinte e dois milhões, seiscentos e sessenta e um mil e seiscentos e cinquenta e nove reais e sessenta e oito centavos); ou de Belo Horizonte, que, utilizando-se os mesmos padrões de referência, possui população de 2.375.151 (dois milhões, trezentos e setenta e cinco mil e cento e cinqüenta e um) habitantes e receita orçamentária realizada de $\mathrm{R} \$$ 4.825.925.739,42 (quatro bilhões, oitocentos e vinte e cinco milhões, novecentos e vinte e cinco mil e setecentos e trinta e nove reais e quarenta e dois centavos).

Nessa senda, para respeitar o princípio da isonomia, não discriminando os Municípios Capitais de seus Estados e em observância ao equilíbrio do

\footnotetext{
${ }^{567}$ FERREIRA FILHO, Manoel Gonçalves. Comentários... Op. cit. p. 221.

${ }^{568}$ IBGE. População nos Estados. Disponível em: <http://www.ibge.gov.br/estadosat/index.php>, acesso em 30 de dez. 2011.

569 IBGE. Finanças Públicas nas Cidades. Os sites para as cidades de Rio Branco, Macapá, Porto Alegre e Belo Horizonte são, respectivamente: Disponível em: <http://www.ibge.gov.br/cidadesat/link.php?uf=ac >,< http://www.ibge.gov.br/cidadesat/link.php?uf=ap>, <http://www.ibge.gov.br/cidadesat/link.php?uf=rs> e <http://www.ibge.gov.br/cidadesat/link.php?uf=mg>, acesso em 30 de dez. 2011.
} 
pacto federativo, defendemos que tais Municípios deveriam possuir os seus próprios Tribunais de Contas, o que, como já explanamos, reforçaria a autonomia de tais entes.

Entretanto, tendo em vista o Brasil contar com mais de cinco mil Municípios, pensamos ser necessário o estabelecimento de outro critério para que os demais Municípios fossem contemplados com Tribunal de Contas e isto em razão das discrepâncias existentes entre eles em relação ao contingente populacional e à receita orçamentária.

Para ilustrar a afirmação, citamos o Município de Caxias do Sul, no Rio Grande do Sul que, no Censo de 2010, apresentou população de 435.564 (quatrocentos e trinta e cinco mil e quinhentos e sessenta e quatro) habitantes e receita orçamentária ${ }^{570}$ realizada, em 2009, de R \$906.925.762,62 (novecentos e seis milhões, novecentos e vinte e cinco mil, setecentos e sessenta e dois reais e sessenta e dois centavos). Por seu turno, o Município de Capitão, também no Rio Grande do Sul, observados os mesmos parâmetros, possui apenas 2.636 (dois mil e seiscentos e trinta e seis) habitantes e receita orçamentária de $\mathrm{R} \$$ 9.630.401,85 (nove milhões, seiscentos e trinta mil, quatrocentos e um reais e oitenta e cinco centavos).

Então, para os Municípios que não são Capitais de Estados, o critério que nos parece razoável concerne, assim, ao preenchimento, de forma cumulativa, de requisitos consistentes em: possuir determinado número de habitantes e contar com orçamento superior a certo montante, tudo de acordo com o que a Constituição dispusesse, por via de Emenda Constitucional, vez que, no sistema atualmente vigente, é vedada a criação de novas Cortes Municipais de Contas, a teor do disposto no artigo 31, § $4^{\circ}$, da Lei Maior.

5.

Outro ponto que merece nosso exame pormenorizado diz respeito ao prazo para o julgamento das contas municipais na Câmara dos Vereadores.

Quanto a este tema, é sabido que o Prefeito tem o prazo de sessenta dias, a contar da abertura da sessão legislativa, para prestar as suas contas relativas ao exercício anterior. Por outro lado, o Tribunal de Contas também tem o prazo de sessenta dias, a contar do seu recebimento, para apreciá-las, elaborando o parecer prévio de acordo

\footnotetext{
${ }^{570}$ IBGE. Finanças Públicas nas Cidades. Os sites para as cidades de Caxias do Sul e Capitão é: Disponível em: <http://www.ibge.gov.br/cidadesat/link.php?uf=rs>.
} 
com o que dispõe a Lei Maior (artigos 84, XXIV e 71, I, respectivamente). Assim, por exemplo, no Município de São Paulo, a sessão legislativa inicia-se no dia 01 de fevereiro e o prazo final para o Prefeito encaminhar suas contas é dia 31 (trinta e um) de março. Apresentadas pelo Prefeito, começa a viger o prazo - de noventa dias na Capital Paulista, de acordo com o disposto no artigo 48, $\mathrm{I}^{571}$, da Lei Orgânica -, o que significa que o Tribunal de Contas do Município de São Paulo tem até o dia 30 (trinta) de junho de cada ano para enviar o parecer prévio à Câmara Municipal, para que esta proceda ao julgamento político das contas referentes ao exercício anterior.

Ocorre que, diferentemente do que acontece com o Prefeito e com o Tribunal de Contas, não há previsão de prazo para que a Câmara Municipal julgue as contas do Prefeito. A justificativa para tal ausência é que ela feriria o princípio da separação de Poderes.

Também aqui discordamos da sistemática constitucional. Pensamos que a fixação de prazo para o julgamento das contas é necessária para se coadunar com o sistema de checks and balances, bem como com o princípio republicano. E, caso fosse considerada a nossa sugestão, também neste caso seria necessária a mudança da Constituição por meio de Emenda Constitucional.

Entendemos que a fixação de um prazo para a Câmara Municipal julgar as contas de governo prestadas pelo Prefeito, que tem direito subjetivo a esse julgamento (o Prefeito tem direito de ter as suas contas julgadas pela Câmara Municipal), também constituiria um freio, pelo Poder Executivo e pela própria sociedade, à tentativa de a Casa do Povo não realizar o julgamento.

Ademais, de que adianta a obrigação de o Prefeito apresentar suas contas e de o Tribunal de Contas as apreciar em prazo determinado, se a Câmara Municipal não as julga? E mais. E se se passarem anos sem que a Câmara as julgue? Imaginemos a hipótese de um parecer prévio que tenha desaprovado as contas do Prefeito.

571 “Art. 48. O controle externo, a cargo da Câmara Municipal, será exercido com o auxílio do Tribunal de Contas do Município de São Paulo, ao qual compete: I - apreciar as contas prestadas anualmente pelo Prefeito, (...) mediante parecer prévio que deverá ser elaborado em 90 (noventa) dias, a contar da data de seu recebimento, que terá seu terno final em 31 de março de cada exercício". BRASIL. Lei Orgânica do Município de São Paulo: atualizada com a Emenda Constitucional n 28/2006. José Fernando Ferreira Brega (Org.). São Paulo: Páginas \& Letras Editora e Gráfica: Associação dos Procuradores do Município de São Paulo, 2006. p. 37. 
Significa que, ao menos do ponto de vista do controle técnico, o Prefeito usou inadequadamente o dinheiro que pertence ao povo. Não tem o povo o direito de ver as contas julgadas pela Casa que o representa, a fim de que contra o mau gestor seja imposta a responsabilidade política, ficando o Prefeito inelegível? Sem o julgamento, pensamos, o povo fica "sem resposta" sobre a boa ou a má versação dos recursos públicos e, ainda, os supostos maus gestores continuam a participar de pleitos eleitorais.

Demais disso, a "relação de confiança" estabelecida entre o vereador e o eleitor, no momento do voto, é quebrada, já que o primeiro descumpre, ao não julgar as contas, as suas obrigações assumidas perante o segundo.

Assim, ainda que se afirme que não se admite a fixação de prazo para o Legislativo julgar, sob pena de ferimento ao princípio da separação de Poderes, para nós, a ausência deste prazo configura desrespeito ao princípio republicano, que também é constitucional. Mais. Fere o direito do povo de ter uma resposta sobre a utilização dos recursos públicos antes de as eleições ocorrerem novamente. Lembre-se que o povo aprova ou desaprova a gestão do Prefeito e, pois, as suas contas, nas urnas, mas as eleições só ocorrem de quatro em quatro anos. Fica o povo, pois, "a descoberto", quando a Câmara dos Vereadores, no caso específico do controle das contas municipais, não as julga. Daí porque entendemos ser recomendável exigir da Câmara dos Vereadores o julgamento das contas municipais em prazo estabelecido.

Por isso, nossa sugestão é a fixação de prazo para a Câmara Municipal julgar as contas do Prefeito, de modo que as contas do exercício anterior sejam julgadas até o dia 31 de dezembro de cada ano, sob pena de, não o fazendo, ser negado o registro da candidatura ao Parlamentar (inelegibilidade), para a legislatura seguinte ou por um prazo determinado. Com esta sistemática, pensamos, as contas seriam julgadas anualmente, exercendo, a Câmara dos Vereadores, o seu controle político sobre os atos contas - do Poder Executivo. Respeitar-se-iam, com isso, o princípio republicano e o povo, este último, titular do Poder.

Não se admitindo o critério de julgamento até o dia 31 (trinta e um) de dezembro de cada ano, pensamos que outra possibilidade - independente da anterior seria o Poder Executivo não repassar à Câmara dos Vereadores os duodécimos respectivos, até o julgamento das contas. Os duodécimos correspondem ao orçamento da Câmara 
Municipal que foi aprovado e que a cada mês é repassado pelo Poder Executivo à Casa das Leis. Funciona, este critério, também como um freio a cargo do Poder Executivo em face da omissão do Poder Legislativo municipal em julgar as contas.

Ressaltamos, outrossim, que a adoção de qualquer destas duas medidas - inelegibilidade de Vereadores que não julgarem as contas municipais até o dia 31 (trinta e um) de dezembro de cada ano ou não repasse dos duodécimos - requer a alteração da legislação federal referente à inelegibilidade e da Constituição Federal, respectivamente.

6. Outro ponto que merece nossa análise pormenorizada diz respeito ao parecer prévio. Em nosso entender, o parecer prévio que o Tribunal de Contas elabora, contendo a apreciação técnica das contas de governo prestadas pelo Prefeito, não tem natureza meramente opinativa. Isto porque a Constituição Federal estabelece, para a esfera municipal, que é necessária a maioria qualificada de dois terços - superior à maioria de três quintos exigida para a aprovação de emenda constitucional - dos votos dos membros da Câmara Municipal para derrubar o parecer prévio que tenha opinado pela aprovação ou pela rejeição das contas.

Não podemos, no entanto, entender que o parecer prévio seja vinculante. Se fosse assim, pensamos, não seria necessária a manifestação da Câmara Municipal ou, se o fosse, serviria ela como mero órgão revisor ${ }^{572}$ do Tribunal de Contas.

\footnotetext{
572 O Ministro Marco Aurélio se manifestou em julgamento do Recurso Extraordinário n 132.747-2/Distrito Federal, onde se discutia se a rejeição das contas do Prefeito, decorrente de parecer prévio elaborado pelo Tribunal de Contas, era capaz de gerar a inelegibilidade do mandatário sem que tivesse havido o julgamento político da Câmara Municipal. O julgamento ocorreu em 1992 e, portanto, antes da vigência da Lei da "Ficha Limpa". Já àquela época o Ministro Marco Aurélio, Relator, pronunciou-se pela impossibilidade de o parecer prévio vincular e causar a inelegibilidade do Prefeito que teve as suas contas rejeitadas pelo Tribunal de Contas. Assim se manifestou o Ministro: "Longe fica de emprestar à apreciação das contas pelo Tribunal [de Contas] contornos de verdadeiro julgamento, só alcançado mediante ato da Câmara Municipal. Sem que ocorra o exame pelos membros que a integram, a peça ofertada pelo Tribunal de Contas, seja favorável ao Prefeito, seja-lhe contrária, permanece como os contornos que lhes são próprios, ou seja, com o valor que lhe é atribuído pela Constituição Federal, de pronunciamento opinativo prévio, a instruir processo perante à Câmara. Aliás, é incongruente a proposição revelada até aqui no enquadramento constitucional da matéria. A uma, porque acaba por apontar que o Tribunal de Contas não possui competência para julgar as contas anuais do Prefeito, muito embora o tenha para contratos dos diversos setores da administração e em relação aos quais o chefe do Poder Executivo apenas esteve ligado como ordenador da despesa. (...) A três, porque implica relegar o papel da Câmara Municipal na fiscalização do Executivo ao de mero Órgão revisor, (...)”. (grifos nossos). Recurso Extraordinário no 132.747-2/Distrito Federal. Relator Min. Marco Aurélio. "Por maioria de votos, em conhecer do recurso e lhe dar provimento, para afastar a declaração de inelegibilidade, vencido o Ministro Carlos Velloso, que dele não conhecia". Julgado em 17/06/92 e publicado no Diário de Justiça de 07/12/95. pp. 18-19. Disponível em: <http://www.stf.jus.br/portal/jurisprudencia/listarJurisprudencia.asp?s1=\%28RE\%24\%2ESCLA\%2E+E+132
} 
Daí porque, com a devida vênia, rechaçamos em parte o entendimento do Professor Hely Lopes Meirelles $^{573}$ de que, em âmbito municipal teria sido criado um sistema misto, em que o parecer prévio vincula até ser julgado pela Câmara e, se obtiver a maioria de dois terços passa a ser meramente opinativo.

Para nós, há, de fato, um sistema híbrido em seara municipal, só que este sistema é formado por duas vontades: a do Tribunal de Contas e a da Câmara Municipal, cada qual realizando sua função preestabelecida: controle técnico pelo primeiro, controle político pelo segundo. Não se sustenta a apreciação do parecer prévio sem o julgamento político e, de outro lado, este não pode ser dado alterando-se o conteúdo do que ficou decidido no parecer prévio. Vale dizer, não se admite que a Câmara dos Vereadores aprove ou desaprove as contas de governo prestadas pelo Prefeito por outros motivos que não os contidos no parecer prévio.

Trata-se, portanto, de uma função - a de controle externo desempenhada por dois órgãos - o Tribunal de Contas e a Câmara Municipal -, órgãos estes que se complementam. Como afirmado pelo Ministro Carlos Ayres Britto, mas naquela ocasião comparando o Poder Judiciário e o Ministério Público, no exercício da função jurisdicional:

"Não se pode exercer a jurisdição senão com a participação do Ministério Público. Senão com a obrigatória participação ou o compulsório auxílio do Ministério Público. Uma só função (a jurisdicional), com dois diferenciados órgãos a servi-la. Sem que se possa falar de superioridade de um perante o outro". ${ }^{574}$ (grifos nossos)

A proposição se encaixa no nosso caso. A função de controle externo é uma só, porém, exercida por dois órgãos: o Tribunal de Contas e a Câmara Municipal, sem que se possa falar em superioridade de um sobre o outro. Daí porque, mais uma vez, asseveramos que o auxílio não é subordinação e sim cooperação obrigatória. Ainda, consoante o Ministro Carlos Ayres Britto:

747\%2ENUME $\% 2 \mathrm{E} \% 29+\mathrm{OU}+\% 28 \mathrm{RE} \% 2 \mathrm{EACMS} \% 2 \mathrm{E}+\mathrm{ADJ} 2+132747 \% 2 \mathrm{EACMS} \% 2 \mathrm{E} \% 29 \&$ base $=$ baseAc ordaos>, acesso em 07 de jan. 2012.

${ }^{573}$ MEIRELLES, Hely Lopes. Direito administrativo... Op. cit. p. 701.

${ }^{574}$ BRITTO, Carlos Ayres. Op. cit. p. 62. 
"Assim como não se pode exercer a jurisdição com o descarte do 'Parquet', também é inconcebível o exercício da função estatal de controle externo sem o necessário concurso ou o contributo obrigatório dos Tribunais de Contas" ${ }^{575}$ (grifos nossos)

Por serem imprescindíveis as presenças e manifestações dos dois órgãos, cada qual com a sua função já devidamente estabelecida, é que afirmamos, conforme já abalizado no item 5.4 (Há controle político quando o Tribunal de Contas elabora o parecer prévio apreciando as contas de governo apresentadas pelo Prefeito?), que o parecer prévio elaborado pelo Tribunal de Contas, contendo a apreciação técnica das contas de governo prestadas pelo Prefeito não tem o condão de - sozinho - causar a inelegibilidade política do mau gestor, tampouco de gerar consequências enquanto as contas não forem julgadas.

Vale dizer, somente o parecer prévio não faz incidir o $\operatorname{artigo~} 1^{\circ}, \mathrm{I}$, “g”, da Lei n 64/90, com as alterações conferidas pela Lei Complementar $n^{\circ}$ 135/10, a Lei da "Ficha Limpa". A responsabilidade política só incidirá se se tratar de decisão irrecorrível da Câmara Municipal e desde que fique comprovado que o Prefeito praticou "irregularidade insanável que configure ato doloso de improbidade administrativa",576. Nesta situação, o Prefeito é apenado com a inelegibilidade por oito anos em decorrência do julgamento político final proferido pela Câmara dos Vereadores. Esta é, aliás, mais uma razão para afirmarmos a imprescindibilidade do julgamento das contas pela Câmara Municipal, tal como defendido anteriormente.

Incide, ademais, a responsabilidade política nas urnas, podendo os eleitores confirmar ou não a continuidade do mandato do Prefeito, por meio do instituto da reeleição ou, então, elegê-lo ou não para cargo diferente. Mas, atente-se que esta modalidade de responsabilidade política só ocorre de quatro em quatro anos, nas urnas.

\footnotetext{
${ }^{575}$ Idem. p. 63.

${ }^{576}$ Dispõe o artigo $1^{\circ}$, I, "g", da Lei no 64/90 com redação dada pela Lei Complementar no 135/10: Art. 1 $^{\text {. }}$. São inelegíveis: I - para qualquer cargo: g) os que tiverem suas contas relativas ao exercício de cargos ou funções públicas rejeitadas por irregularidade insanável que configure ato doloso de improbidade administrativa, e por decisão irrecorrível do órgão competente, salvo se esta houver sido suspensa ou anulada pelo Poder Judiciário, para as eleições que se realizarem nos 8 (oito) anos seguintes, contados a partir da data da decisão, aplicando-se o disposto no inciso II do art. 71 da Constituição Federal, a todos os ordenadores de despesa, sem exclusão de mandatários que houverem agido nessa condição. BRASÍLIA (BR). Lei Complementar $n^{\circ}$ 64, de 18 de maio de 1990, com redação dada pela Lei Complementar $n^{\circ} 135$, de 4 de junho de 2010. Estabelece, de acordo com o art. 14, § $9^{\circ}$ da Constituição Federal, casos de inelegibilidade, prazos de cessação, e determina outras providências. Diário Oficial da União de 18 de maio de 1990
} 
Resta claro, portanto, que o controle político pertence ao povo e é exercido por ele nas urnas ou na Câmara Municipal, por meio de seus representantes, quando esta julga as contas apresentadas pelo Prefeito. Não cabe tal controle ao Tribunal de Contas, porque neste órgão os que exercem o poder não são representantes do povo. Não se estabelece, portanto, a "relação de confiança", decorrente do mandato, entre povo e Conselheiros do Tribunal de Contas, relação esta que é necessária para ensejar o controle político e fazer incidir a responsabilidade política.

Contudo, consoante por nós já explicado, o Tribunal de Contas, tem "certa função política",577, porque participa da função de controle externo, que termina com o julgamento político na Câmara dos Vereadores. É dizer, a aprovação das contas municipais requer a participação conjunta do Tribunal de Contas elaborando o parecer prévio e da Câmara dos Vereadores realizando o julgamento político. Ademais, o que se avalia com o julgamento das contas municipais não é somente a gestão do Prefeito durante o ano, como também a sua própria pessoa, através das urnas, que confirmarão ou não sua permanência no Poder. E o Tribunal de Contas, através do parecer prévio, "participa" deste julgamento político, exercendo, pois, esta "certa função política" a que nos referimos, sem que com isso se queira afirmar que exerce controle político, vez que este pertence, como já aduzido, somente ao povo.

7.

Por fim, compete-nos reforçar que, para nós, a natureza da competência exercida pelo Tribunal de Contas e pela Câmara Municipal na aprovação das contas municipais é compartilhada entre estes dois órgãos.

A relação entre a Corte de Contas e a Câmara dos Vereadores é de verdadeira cooperação, como já foi por nós adiantado. Há, portanto, entre este Poder e aquele órgão constitucional autônomo verdadeira distribuição do poder político, tal como ensina Karl Loewenstein, consoante já exposto no item 5.5 (A natureza da competência exercida pelo Tribunal de Contas e pela Câmara Municipal na aprovação das contas municipais):

"O Estado constitucional se fundamenta no princípio da distribuição do poder. A distribuição do poder existe quando vários e independentes detentores do poder ou órgãos estatais participam da formação da vontade estatal. As funções que lhes foram conferidas estão submetidas

\footnotetext{
${ }^{577}$ MAGALHÃES, Roberto Barcellos de. Op. cit. p. 216.
} 
a um controle respectivo por meio dos outros detentores do poder. Pelo fato de estar distribuído, o exercício do poder está necessariamente controlado". ${ }^{578}$ (grifos e tradução nossos)

Vale reafirmar: a distribuição do poder político existe entre um Poder (o Legislativo) e um órgão constitucional autônomo (o Tribunal de Contas), cada qual possuindo uma competência preestabelecida na aprovação das contas municipais: o Tribunal de Contas, realizando o controle técnico por meio da elaboração de um parecer prévio em que aprecia as contas de governo anualmente prestadas pelo Prefeito e a Câmara Municipal, julgando-as e exercendo, com isso, o controle político sobre as contas mencionadas. Não se admite, ademais, a interferência de um órgão na atividade desempenhada pelo outro, sob pena de haver desvio de finalidade.

Agindo assim, cada qual no exercício de sua função preestabelecida, por meio de competência compartilhada, o poder político estará distribuído e, portanto, limitado.

\footnotetext{
578 "El Estado constitucional se basa em el principio de la distribución del poder. La distribución del poder existe cuando varios e independientes detentadores del poder u órganos estatales participan en la formación de la voluntad estatal. La s funciones que les han sido asignadas están sometidas a un respectivo control a través de los otros detentadores del poder; como está distribuido, el ejercicio del poder político está necesariamente controlado". LOEWENSTEIN, Karl. Op. cit. p. 50.
} 


\section{BIBLIOGRAFIA}

[s. n.]. Tribunais de Contas e instituições congêneres em diferentes países. Gabinete do Conselheiro Presidente. Lisboa: 1992. p. 228.

AGESTA, Luis Sanchez. Princípios de teoria política. 2a impresión. Madrid: Editora Nacional, 1967.

AGUIAR, Afonso Gomes; AGUIAR, Márcio Paiva de. O Tribunal de Contas na ordem constitucional. $2^{\text {a }}$ ed. Belo Horizonte: Fórum, 2008.

AMARAL JÚNIOR, José Levi Mello do. O Poder Legislativo na democracia contemporânea: a função de controle político dos parlamentos na democracia contemporânea. Revista de Informação Legislativa. Ano 42, n. 168. Brasília: out./dez., 2005. pp. 7-17. Disponível em: <http://www2.senado.gov.br/bdsf/item/id/905>, acesso em 15 de jan. 2010.

ANDRADA, Antonio Carlos Doorgal de. A natureza jurídica do parecer prévio emitido pelos Tribunais de Contas estaduais e admissibilidade de recurso. Disponível em: <http://www.antoniocarlosandrada.com.br/files/artigos/130420101521395500.pdf>, acesso em 12 de dez. 2010.

ANDRADA, Antonio Carlos Doorgal; BARROS, Laura Correa de. O Parecer Prévio como instrumento de transparência, controle social e fortalecimento da cidadania. Revista do Tribunal de Contas do Estado de Minas Gerais. Ano XXVIII, v. 77, n. 4. Belo Horizonte: out./nov./dez, 2010. pp. 51-73.

ARAÚJO, Edmir Netto de. Curso de direito administrativo. $4^{\mathrm{a}}$ ed. rev. e atual. São Paulo: Saraiva, 2009.

ARAÚJO, Julio Cesar Manhães de. Controle da atividade administrativa pelo Tribunal de Contas na Constituição de 1988. Curitiba: Juruá, 2010.

ARAÚJO, Marcos Valério de. Como controlar o Estado: reflexões e propostas sobre o controle externo nas Américas, Portugal e Espanha. Brasília: UNITEC, 1992. Trabalho premiado pelo Tribunal de Cuentas de Espana e pela Sociedad Estatal Quinto Centenário. 
Biblioteca Digital do Tribunal de Contas da União. Disponível em: $<$ http://portal2.tcu.gov.br/portal/pls/portal/docs/2058856.PDF>, acesso em 20 de out. 2011.

ARISTÓTELES. A política. Tradução de Nestor Silveira Chaves. São Paulo: Edições Cultura Brasileira S/A, [s.n].

ATALIBA, Geraldo. República e Constituição. $2^{\mathrm{a}}$ ed. $4^{\mathrm{a}}$ tiragem. atual. por Rosalea Miranda Folgosi. São Paulo: Malheiros, 2007.

AULETE, Caldas. Minidicionário contemporâneo da Língua Portuguesa. Rio de Janeiro: Nova Fronteira, 2004.

BARBOSA, Ruy. Commentarios á Constituição Federal Brasileira. v. VI: art. 72 (conclusão) a 91 (Disposições Geraes) e Disposições Transitorias. São Paulo: Livraria Acadêmica, Saraiva, 1934.

BASTOS, Celso Ribeiro; MARTINS, Ives Gandra. Comentários à Constituição do Brasil (promulgada em 5 de outubro de 1988). $3^{\text {a }}$ ed. atual. v. 4. Tomo II: arts. 70 a 91. São Paulo: Saraiva, 2002.

BERGERON, Gérard. Fonctionnement de l'État. $2^{\mathrm{a}}$ ed. Paris: Librairie Armand Colin, $1965 . \quad$ pp. 77-78. Disponível em: <http://classiques.uqac.ca/contemporains/bergeron_gerard/fonctionnement_de_Etat/fonctio nnement_de_Etat_sommaire.html>, acesso em 21 de ago. 2011.

BOBBIO, Norberto. Teoria geral da política: a filosofia política e as lições dos clássicos. BOVERO, Michelangelo (Org.). Tradução de Daniela Beccaccia Versiani. 6 a Tiragem. Rio de Janeiro: Campus, 2000.

BONAVIDES, Paulo. Ciência política. 10ª ed. rev. e atual. São Paulo: Malheiros, 2000.

BORJA, Rodrigo. Derecho político y constitucional. $2^{\text {a }}$ ed. Primera reimpresión. México: Fondo de Cultura Económica, 1992.

BOSON, Erik. O direito fundamental ao governante probo, a análise da vida pregressa do candidato e a presunção de inocência/não culpa: uma análise à luz da Lei da "Ficha Limpa”. Revista da Procuradoria Geral do Estado de São Paulo. n. 72. São Paulo: jul./dez., 2010. pp. 115-138. 
BRAGUIM, Roberto Tanzi. Tribunais de Contas: presente e futuro. In: TCM 40: edição comemorativa dos 40 anos do Tribunal de Contas do Município de São Paulo. São Paulo: Imprensa Oficial do Estado de São Paulo, 2008. pp. 35-41.

BRAIBANT, QUESTIAUX E WIENER, Le contrôle de l'administration et la protection des citoyens. Paris: Cujas, 1973. p. 305. Apud MEDAUAR, Odete. Controle da administração pública. São Paulo: Revista dos Tribunais, 1993.

BRITTO, Carlos Ayres. O regime constitucional do Tribunal de Contas. In: SOUZA, Alfredo José de... et al. O novo Tribunal de Contas: órgão protetor dos direitos fundamentais. $3^{\text {a }}$ ed. rev. e ampl. Belo Horizonte: Fórum, 2005. pp. 59-75.

BUGARIN, Paulo Soares. O princípio constitucional da economicidade na jurisprudência do Tribunal de Contas da União. 2a ed. rev. e ampl. Belo Horizonte: Fórum, 2011.

CAGGIANO, Monica Herman Salem. A emergência do Poder Judiciário como contraponto ao bloco monocolor Legislativo/Executivo. In: MORAES, Alexandre de (Coord.). Os 20 anos da Constituição da República Federativa do Brasil. São Paulo: Atlas, 2009. pp. 99-123.

. Controle parlamentar da administração. Revista de Direito Público.

Ano 24, n. 96. São Paulo: Revista dos Tribunais, out/dez., 1990. pp. 148-153.

. Direito parlamentar e direito eleitoral. Barueri, SP: Manole, 2004. . Sistemas eleitorais x representação política. São Paulo: [s.n], 1987.

Oposição na política: propostas para uma rearquitetura da democracia. São Paulo: Angelotti, 1995.

CAGNONI, Jose Anibal. El derecho constitucional uruguayo. $2^{\mathrm{a}}$ ed. actual. e ampl. Uruguay: UY Libros, 2006.

CANOTILHO, J. J. Gomes de; MOREIRA, Vital. Constituição da República Portuguesa Anotada. v. I. São Paulo: Revista dos Tribunais; Coimbra: Coimbra Editora, 2007.

CASTARDO, Hamilton Fernando. O Tribunal de Contas no ordenamento jurídico brasileiro. Campinas, SP: Millenium, 2007. 
CASTRO, José Nilo de. Direito municipal positivo. $7^{\text {a }}$ ed. rev. e atual. Belo Horizonte: Del Rey, 2010.

CAVALCANTI, Augusto Sherman. Aspectos da competência julgadora dos Tribunais de Contas. Revista de Direito Administrativo. v. 237. Rio de Janeiro: Renovar, jul.-set., 2004. pp. 327-339.

CHAVES, Francisco Eduardo Carrilho. Controle externo da gestão pública: a fiscalização pelo Legislativo e pelos Tribunais de Contas. $2^{\mathrm{a}}$ tiragem. Niterói: Impetus, 2007.

CORRALO, Giovani da Silva. O Poder Legislativo municipal: aportes teóricos e práticos para a compreensão e o exercício da função parlamentar nas Câmaras de Vereadores. São Paulo: Malheiros, 2008.

COSTA, Antonio Tito. O vereador e a Câmara Municipal: problemas municipais. São Paulo: Revista dos Tribunais, 1964.

COTTA, Maurizio. Verbete parlamento. In: BOBBIO, Norberto; MATTEUCCI, Nicola (Coord.). Dicionário de política L-Z. Gianfranco Pasquino (redator). Tradução de José Aricó e Jorge Tula. 2a ed. Madrid: Siglo Veintiuno de España Editores, 1983.

CRETELLA JÚNIOR, José. Comentários à Constituição Brasileira de 1988. $2^{\mathrm{a}}$ ed. v. V (arts. 38 a 91). Rio de Janeiro: Forense Universitária, 1997.

DALLARI, Adílson Abreu. Controle compartilhado da administração da justiça. In: FIGUEIREDO, Marcelo; PONTES FILHO, Valmir (Org.). Estudos de Direito Público em homenagem a Celso Antônio Bandeira de Mello. São Paulo: Malheiros, 2006. pp. 19-45.

DALLARI, Dalmo de Abreu. Elementos de teoria geral do Estado. 22a ed. atual. São Paulo: Saraiva, 2001.

Estado de Direito e direitos fundamentais. In: FIGUEIREDO, Marcelo; PONTES FILHO, Valmir (Org.). Estudos de Direito Público em homenagem a Celso Antônio Bandeira de Mello. São Paulo: Malheiros, 2006. pp. 217-232.

DELMONDES, Edna. A interação do Tribunal de Contas com o parlamento. Rio de Janeiro: Renovar, 2007. 
DI PIETRO, Maria Sylvia. Coisa julgada: aplicabilidade a decisões do Tribunal de Contas da União. Revista do Tribunal de Contas da União.v. 27. n ${ }^{\circ}$ 70. Brasília: out./dez., 1996. pp. 23-36.

Direito administrativo. $21^{\text {a }}$ ed. São Paulo: Atlas, 2008.

DICIONÁRIO Eletrônico Houaiss da Língua Portuguesa. Instituto Antônio Houaiss. Rio de Janeiro: Objetiva, 2001. 1 CD-ROM.

DICIONÁRIO Melhoramentos da Língua Portuguesa. Antônio Houaiss (apresentação). São Paulo: Melhoramentos, 1994.

FAGUNDES, M. Seabra. O contrôle dos atos administrativos pelo Poder Judiciário. $4^{\mathrm{a}}$ ed. atual. Rio de Janeiro: Forense, 1967.

FAGUNDES, Tatiana Penharrubia. A função do Tribunal de Contas no Estado Democrático de Direito brasileiro. In: MESSA, Ana Flávia; THEOPHILO JÚNIOR, Roque (Org.). Estado e Economia: estudos em homenagem a Ademar Pereira. São Paulo: Saraiva, 2011. pp. 233-247.

Reforma política no Peru. Cadernos de Pós-Graduação em Direito: estudos e documentos de trabalho. Tendências e desafios do constitucionalismo latinoamericano. n. 3. São Paulo: Comissão de Pós-Graduação da Faculdade de Direito da USP, 2011. pp. 73-84.

FARIA, Rodrigo Oliveira de. Título VIII - Do controle da execução orçamentária. In: Orçamentos públicos: a Lei 4.320/1964 comentada. CONTI, José Maurício (Coord.). São Paulo: Revista dos Tribunais, 2008. pp. 221-248.

FERNANDES, Francisco. Dicionário de Sinônimos e Antônimos da Língua Portuguesa: de acordo com a ortografia oficial brasileira. $43^{\mathrm{a}}$ ed. rev. e ampl. por Celso Luft. São Paulo: Globo, 2005.

FERNANDES, Jorge Ulisses Jacoby. Tribunais de Contas do Brasil: jurisdição e competência. $2^{\mathrm{a}}$ ed. Belo Horizonte: Fórum, 2005.

FERREIRA FILHO, Manoel Gonçalves. A democracia no limiar do século XXI. São Paulo: Saraiva, 2001. 
Comentários à Constituição Brasileira de 1988. $3^{\mathrm{a}}$ ed. atual. v. 1 (arts. $1^{\circ}$ a 103). São Paulo: Saraiva, 2000.

. Curso de direito constitucional. $34^{\mathrm{a}}$ ed. rev. e atual. São Paulo:

Saraiva, 2008.

. O poder e seu controle. Revista de Informação Legislativa. Ano 21, n. 84. Brasília: out./dez., 1984. pp. 69-94.

Poder Judiciário na Constituição de 1988: judicialização da política e politização da justiça. In: FERREIRA FILHO, Manoel Gonçalves. Aspectos de direito constitucional contemporâneo. $2^{a}$ ed. São Paulo: Saraiva, 2009. pp. 189-217.

Princípios fundamentais do direito constitucional. São Paulo:

Saraiva, 2009.

FERREIRA, Cláudio. O julgamento das contas públicas e o sistema de controle parlamentar do governo na Constituição Brasileira de 1988. Dissertação de Mestrado. Orientador Prof. Elival da Silva Ramos. Faculdade de Direito. São Paulo: 2011.

FIGUEIREDO, Marcelo. A crise no entendimento clássico do princípio da legalidade administrativa e temas correlatos. In: FIGUEIREDO, Marcelo; PONTES FILHO, Valmir (Org.). Estudos de Direito Público em homenagem a Celso Antônio Bandeira de Mello. São Paulo: Malheiros, 2006. pp. 424-444.

O controle da moralidade na Constituição. $1^{\mathrm{a}}$ ed. $2^{\mathrm{a}}$ tiragem. São Paulo: Malheiros, 2003.

FUGAGNOLI, Maria Carolina Barros Carvalho. Da competência do Tribunal de Contas para julgar as contas do Prefeito ordenador de despesas: uma análise do artigo 71, incisos I e II da Constituição Federal, aplicado simetricamente no âmbito municipal. Revista da ESMAPE. v. 12, n. 25. Recife: [s.n], jan./jun. 2007. pp. 889-914.

GOMES, Emerson Cesar da Silva. Tribunais de Contas do Brasil: composição, organização e competências. Conteúdo Jurídico: Brasília-DF: 22 jun. 2009. Disponível em: <http://www.conteudojuridico.com.br/?artigos\&ver=2.24213>, acesso em 07 de jul. 2011. 
GUALAZZI, Eduardo Lobo Botelho. Regime jurídico dos Tribunais de Contas. São Paulo: Revista dos Tribunais, 1992.

GUIMARÃES, Fernando Augusto Mello. Julgamento das contas anuais pelo Tribunal de Contas (aspectos controvertidos). Revista do Tribunal de Contas do Estado do Paraná. n. 117. Curitiba: jan./mar., 1996. pp. 71-91.

LEMBO, Cláudio. A pessoa: seus direitos. Barueri, SP: Manole, 2007. . Eles temem a liberdade. Barueri, São Paulo: Minha Editora; São Paulo: CEPES, 2006. . Participação política e assistência simples no direito eleitoral. Rio de Janeiro: Forense Universitária, 1991. . Visões do cotidiano. Barueri, São Paulo: Manole, 2012.

LOCKE, John. Segundo tratado sobre o governo civil e outros escritos: ensaio sobre a origem, os limites e os fins verdadeiros do governo civil. Tradução de Magda Lopes e Marisa Lobo da Costa. $4^{\mathrm{a}}$ ed. Bragança Paulista: Editora Universitária São Francisco; Petrópolis: Vozes, 2006.

LOEWENSTEIN, Karl. Teoría de la Constitución. Traducción y estudio sobre la obra por Alfredo Gallego Anabitarte. Barcelona: Editorial Ariel, 1976.

LOMBA, Pedro. Teoria da responsabilidade politica. Coimbra: Coimbra Editora, 2008.

MAGALHÃES, Roberto Barcellos de. A Constituição Federal de 1967 comentada Tomo I: arts. 1 a 106. Rio de Janeiro: José Konfino Editor, 1967.

MAZZILli, Hugo Nigro. O Ministério Público no Tribunal de Contas. Revista dos Tribunais. Ano 78. v. 650. São Paulo: Revista dos Tribunais, dez., 1989. pp. 40-52.

MEDAUAR, Odete. Controle da administração pública pelo Tribunal de Contas. Revista de Informação Legislativa. Ano 27, n. 108. Brasília: out./dez., 1990. pp. 101-126. Controle da administração pública. São Paulo: Revista dos Tribunais, 1993. 
Direito administrativo brasileiro. $13^{\mathrm{a}}$ ed. rev. e atual. São Paulo:

Revista dos Tribunais, 2009.

MEIRELLES, Hely Lopes. Direito administrativo brasileiro. $31^{\text {a }}$ ed. atual. por Eurico de Andrade Azevedo, Délcio Balestero Aleixo e José Emmanuel Burle Filho. São Paulo: Malheiros, 2005.

Direito municipal brasileiro. $10^{\mathrm{a}}$ ed. atual. por Izabel Camargo Lopes Monteiro e Célia Marisa Prendes. São Paulo: Malheiros, 1998.

MELlO, Oswaldo Aranha Bandeira de. Princípios gerais de direito administrativo. v. 2. Rio de Janeiro: Forense, 1979. p. 575 Apud DI PIETRO, Maria Sylvia Zanella. Direito administrativo. $21^{\text {a }}$ ed. São Paulo: Atlas, 2008. p. 219.

. Princípios gerais de direito administrativo. v. 2. Rio de Janeiro:

Forense, 1979. p. 575 Apud DI PIETRO, Maria Sylvia Zanella. Coisa julgada: aplicabilidade a decisões do Tribunal de Contas da União. Revista do Tribunal de Contas da União.v. 27. no 70. Brasília: out./dez., 1996. pp. 27-28.

MILESKI, Helio Saul. O controle da gestão pública. São Paulo: Revista dos Tribunais, 2003.

MIRANDA, Pontes de. Comentários à Constituição de 1946. $2^{\mathrm{a}}$ ed. rev. e aum. v. II (arts. 15-97). São Paulo: Max Limonad, 1953.

MONTESQUIEU, Charles-Louis de Secondat, Baron de La Brède et de. O espírito das leis. Apresentação de Renato Janine Ribeiro. Tradução de Cristina Murachco. $3^{\mathrm{a}}$ ed. São Paulo: Martins Fontes, 2005.

O espírito das leis: as formas de governo, a federação, a divisão dos poderes, presidencialismo versus parlamentarismo. Introdução, tradução e notas de Pedro Vieira Motta. $7^{\text {a }}$ ed. São Paulo: Saraiva, 2000.

MORAES, Alexandre de. Direito constitucional. 24a ed. São Paulo: Atlas, 2009.

MORAES, Filomeno. Verbete Poder. In: BARRETO, Vicente de Paulo (Coord.). Dicionário de filosofia do direito. São Leopoldo: Unisinos e Rio de Janeiro: Renovar, 2006. pp. 640-642. 
MOREIRA NETO, Diogo de Figueiredo. O Parlamento e a sociedade como destinatários do trabalho dos Tribunais de Contas. In: SOUSA, Alfredo José de et al. O novo Tribunal de Contas: órgão protetor dos direitos fundamentais. $3^{\mathrm{a}}$ ed. rev. e ampl. Belo Horizonte: Fórum, 2005. pp. 77-130.

MUSSO, Enrico Spagna. Diritto costituzionale. II ed. Padova: CEDAM - Casa Editrice Dott. Antonio Milani, 1986.

RANIERI, Nina Beatriz Stocco. Aspectos jurídicos da autonomia universitária no Brasil. Revista CEJ. n. 31. Brasília: out./dez., 2005. pp. 19-30.

- Governabilidade e Estado Democrático de Direito: o uso e o controle das medidas provisórias. In: GARCIA, Maria. (Coord.). Democracia hoje. Um modelo político para o Brasil. São Paulo: Instituto Brasileiro de Direito Constitucional, Celso Bastos Editor, 1997. pp. 115-133.

REALE, Miguel. Teoria do direito e do estado. $5^{\mathrm{a}}$ ed. rev. São Paulo: Saraiva, 2000.

SALDANHA, Nelson. O estado moderno e a separação de poderes. São Paulo: Saraiva, 1987.

SANSON, Alexandre. Dos institutos de democracia semidireta (plebiscito, referendo e iniciativa popular) como fontes de fortalecimento da cidadania ativa. Dissertação de Mestrado apresentada na Universidade Presbiteriana Mackenzie. São Paulo, 2007.

SANTOS, Jair Lima. Tribunal de Contas da União \& controles estatal e social da administração pública. $1^{\mathrm{a}}$ ed. $4^{\mathrm{a}}$ tiragem. Curitiba: Juruá, 2006.

SCHMITT, Carl. Teoría de la Constitución. Traducción de Francisco Ayala. Madrid: Editorial Revista de Derecho Privado, 1934.

SILVA, José Afonso da. Curso de direito constitucional positivo. $25^{\mathrm{a}}$ ed. rev. e atual. São Paulo: Malheiros, 2005.

Processo constitucional de formação das leis. $2^{\mathrm{a}} \mathrm{ed}, 2^{\mathrm{a}}$ tiragem. São Paulo: Malheiros, 2007. 
SMANIO, Gianpaolo Poggio. A conceituação da cidadania brasileira e a Constituição Federal de 1988. In: MORAES, Alexandre de. (Coord.). Os 20 anos da Constituição da República Federativa do Brasil. São Paulo: Atlas, 2009. pp. 333-346.

As dimensões da cidadania. Revista da Jurídica: novos direitos e proteção da cidadania. Ano 2. São Paulo: Escola Superior do Ministério Público de São Paulo, jan./jun, 2009. pp. 13-23.

SOUSA, Alfredo José. O Tribunal de Contas de Portugal na actualidade. In: SOUSA, Alfredo José et al. O novo Tribunal de Contas: órgão protetor dos direitos fundamentais. $3^{\mathrm{a}}$ ed. rev. e ampl. Belo Horizonte: Fórum, 2005. pp. 17-38.

STOPPINO, Mario. Verbete Poder. In: BOBBIO, Norberto; MATTEUCCI, Nicola (Coord.). Dicionário de política L-Z. Gianfranco Pasquino (redator). Tradução de José Aricó e Jorge Tula. 2a ed. Madrid: Siglo Veintiuno de España Editores, 1983.

TAVARES, José F. F.. O Tribunal de Contas: do visto em especial: conceito, natureza e enquadramento na actividade de administração. Coimbra: Almedina, 1998.

VALENZUELA, Francisco Berlín. Derecho parlamentario. $4^{\mathrm{a}}$ reimpresión. México: Fondo de Cultura Económica, 2000.

VASCONCELOS, Pedro Carlos Bacelar de. Teoria geral do controlo jurídico do poder público. Lisboa: Edições Cosmos, 1996.

VILAÇA, Marcos. Tema II: As relações das Instituições Supremas de Controlo com o Parlamento. IV Encontro das Instituições Supremas de Controlo da CPLP. p. 43. Disponível em: <http://www.tcontas.pt/pr/publicacoes/outras/enc_cplp/4enc.pdf>, acesso em 14 de abr. 2011.

WALINE, Jean. L'evolution du contrôle de l'administration depuis um siècle. Revue du Droit Public et de la Science Politique. set-out., 1984. p. 1349. Apud MEDAUAR, Odete. Controle da administração pública. São Paulo: Revista dos Tribunais, 1993. p. 110.

WILLEMAN, Marianna Montebello. O princípio republicano e os Tribunais de Contas. Revista Interesse Público. Ano X, n. 50. Belo Horizonte: jul./ago, 2008. pp. 277-302. 


\section{Textos Legais:}

BRASÍlLIA (BR). Lei Complementar no 25, de 25 de agosto de 1994. Dispõe sobre a Lei Orgânica do Tribunal de Contas dos Municípios do Pará e dá outras providências. Disponível em: <http://www.tcm.pa.gov.br/component/rokdownloads/downloads/leis/39lei-organica-do-tcmpa-1994.html>, acesso em 17 de nov. 2011.

BRASIL. Constituição (1988). Constituição da República Federativa do Brasil: promulgada em 5 de outubro de 1988: atualizada até a Emenda Constitucional $\mathrm{n}^{\circ}$ 67, de 22-12-2010. 45 ed. ampl. São Paulo: Saraiva, 2011.

BRASIL. Deliberação no 34, de 10 de março de 1983. Institui o Regimento Interno do Tribunal de Contas do Município do Rio de Janeiro. Disponível em: <http://www.tcm.rj.gov.br/Noticias/Informa/RI2.pdf>, acesso em 17 de nov. 2011.

BRASIL. Lei Complementar nº 006, de 06 de dezembro de 1991, alterada pela Lei Complementar $\mathrm{n}^{\circ}$ 14, de 25 de abril de 1998. Trata da Lei Orgânica do Tribunal de Contas dos Municípios do Estado da Bahia e dá outras providências. Disponível em: <http://www.tcm.ba.gov.br/leiorg.shtml>, acesso em 17 de nov. 2011.

BRASIL. Lei Complementar nº 01, de 9 de maio de 1994 (Lei Orgânica do Tribunal de $\begin{array}{llllll}\text { Contas do Distrito } & \text { Federal). Disponível }\end{array}$ <http://www.tc.df.gov.br/web/site/biblioteca-de-documentos>, acesso em 10 de jan. 2012.

BRASIL. Lei Complementar $n^{\circ}$ 269, de 22 de janeiro de 2007. Trata da Lei Orgânica do Tribunal de Contas do Estado de Mato Grosso. Disponível em: <http://www.tce.mt.gov.br/legislacao?categoria=4>, acesso em 10 de jan. 2012;

BRASIL. Lei Complementar $\mathrm{n}^{\circ}$ 48, de 28 de junho de 1990, com as alterações da Lei Complementar $n^{\circ}$ 117, de 2005. Trata da Lei Orgânica do Tribunal de Contas do Estado do $\begin{array}{lllll}\text { Mato Grosso } & \text { do } & \text { Sul. } & \text { Disponível }\end{array}$ <http://www.tce.ms.gov.br/portal/legislacao_servico_consulta>, acesso em 10 de jan. 2012;

BRASIL. Lei $\mathrm{n}^{\circ}$ 13.877, de 23 de julho de 2004. Dispõe sobre a reorganização administrativa do Tribunal de Contas do Município de São Paulo e de seu Quadro de Pessoal, altera dispositivos das Leis $\mathrm{n}^{\circ} 9.167$, de 3 de dezembro de 1980 e $\mathrm{n}^{\circ} 11.548$, de 21 de junho de 1994, procede às adaptações necessárias às normas da EC 19/98 e 20/98 e dá 
outras

providências.

Disponível

em:

<http://www.tcm.sp.gov.br/legislacao/lorgtcm/13877.htm>, acesso em 10 de jan. 2012.

BRASIL. Lei ${ }^{\circ} 15.958$, de 18 de janeiro de 2007, com as alterações da Lei $\mathrm{n}^{\circ} 16.467$, de 5 de maneiro de 2009 e da Lei $n^{\circ} 17.288$, de 19 de abril de 2011. Trata da Lei Orgânica do Tribunal de Contas dos Municípios do Estado de Goiás. Disponível em: <http://www.tcm.go.gov.br/site/legislacao/indexLegislacao.jsf $>$, acesso em 10 de jan. 2012.

BRASIL. Lei $\mathrm{n}^{\circ} 16.168$, de 11 de dezembro de 2007, com as alterações da Lei $\mathrm{n}^{\circ} 16.925$, de 02 de março de 2010 e da Lei $n^{\circ}$ 17.260, de 26 de janeiro de 2011. Trata da Lei Orgânica do Tribunal de Contas do Estado de Goiás. Disponível em: <http://tcenet.tce.go.gov.br/Downloads/Arquivos/000100/Lei\%20organica\%203.0.pdf>, acesso em 10 de jan. 2012;

BRASIL. Lei ${ }^{\circ}$ 9.167, de 03 de dezembro de 1980 com as alterações da Lei $\mathrm{n}^{\circ} 13.877$, de 23 de julho de 2004. Trata da Lei Orgânica do Tribunal de Contas do Município de São Paulo. Disponível em: <http://www.tcm.sp.gov.br/legislacao/lorgtcm/loc_t1.htm>, acesso em 10 de jan. 2012.

BRASIL. Lei Orgânica do Município de São Paulo: atualizada com a Emenda Constitucional $n^{\circ}$ 28/2006. José Fernando Ferreira Brega (Org.). São Paulo: Páginas \& Letras Editora e Gráfica: Associação dos Procuradores do Município de São Paulo, 2006.

BRASÍLIA (BR). Lei Complementar n ${ }^{\circ}$ 101, de 04 de maio de 2000. Estabelece normas de finanças públicas voltadas para a responsabilidade na gestão físcal e dá outras providências. Diário Oficial da União de 05 de maio de 2000.

BRASÍLIA (BR). Lei Complementar nº 64, de 18 de maio de 1990, com redação dada pela Lei Complementar $n^{\circ} 135$, de 4 de junho de 2010. Estabelece, de acordo com o art. 14, § $9^{\circ}$ da Constituição Federal, casos de inelegibilidade, prazos de cessação, e determina outras providências. Diário Oficial da União de 18 de maio de 1990.

BRASÍLIA (BR). Lei federal $n^{\circ}$ 9.784, de 29 de janeiro de 1999. Regula o processo administrativo no âmbito da Administração Pública Federal. Diário Oficial da União de 1 de fevereiro de 1999 e retificado em 11 de março de 1999. 
BRASÍLIA (BR). Lei $\mathrm{n}^{\mathrm{o}}$ 1.079, de 10 de abril de 1950. Disponível em: <http://www.planalto.gov.br/ccivil_03/leis/L1079consol.htm>, acesso em 06 de jan. 2012.

Constitucion du 4 de octobre de 1958. Disponível em: <http://www.conseilconstitutionnel.fr/conseil-constitutionnel/francais/la-constitution/la-constitution-du-4octobre-1958/texte-integral-de-la-constitution-de-1958.5074.html\#titre5>, acesso em 27 de nov. 2011.

Constituição da República Portuguesa com a VII Revisão Constitucional de 2005. Disponível em: <http://www.parlamento.pt/Legislacao/Paginas/ConstituicaoRepublicaPortuguesa.aspx>, acesso em 28 de nov. 2011.

Costituzione della Repubblica Italiana. Disponível em: <http://www.senato.it/documenti/repository/costituzione.pdf $>$, acesso em 26 de nov. 2011.

Emenda Constitucional $\mathrm{n}^{\mathrm{o}} 1$, de 17 de outubro de 1969. Disponível em: <http://www.planalto.gov.br/ccivil_03/constituicao/emendas/emc_anterior1988/emc0169.htm>, acesso em 06 de nov. 2011.

SÃO PAULO (SP). Constituição do Estado de São Paulo: anotada e atualizada até Emenda Constitucional $\mathrm{n}^{\mathrm{o}}$ 14, de 12.03.2002. $2^{\mathrm{a}}$ ed. rev., anotada e atual. São Paulo: Imprensa Oficial do Estado, 2002.

\section{Jurisprudência:}

Ação Direta de Inconstitucionalidade no 397-6, Rel. Min. Eros Grau, v. u., julgado em 03/08/05 e publicado no diário de Justiça de 09/12/05. Disponível em: $<$ http://redir.stf.jus.br/paginadorpub/paginador.jsp?docTP=AC\&docID=266336>, acesso em 17 de nov. 2011.

Ação Direta de Inconstitucionalidade $n^{0}$ 849-8/Mato Grosso. Rel. Min. Sepúlveda Pertence. Por maioria de votos julgada procedente a ação direta e, em consequência, declarada a inconstitucionalidade da Emenda Constitucional $n^{\circ}$ 1, de 10/12/91, do Estado do Mato Grosso. Julgado em 11 de fevereiro de 1999. Disponível em: < 
http://redir.stf.jus.br/paginadorpub/paginador.jsp?docTP=AC\&docID=266565>. Acesso em 12 de dez. 2011.

Ação Direta de Inconstitucionalidade $n^{\circ}$ 1779-1/Pernambuco. Rel. Min. Ilmar Galvão. Tribunal Pleno. Julgado em 23/04/98 e publicado no Diário de Justiça de 22/05/98. Disponível em: <http://www.stf.jus.br>, acesso em 14 de mar. 2008.

Ação Direta de Inconstitucionalidade no 1964-3/Espírito Santo. Rel. Min. Sepúlveda Pertence. "Por maioria de votos, em deferir o pedido de medida cautelar, para suspender, até a decisão final da ação direta, a eficácia das expressões 'e o Presidente da Câmara', 'e pela Mesa da Assembléia Legislativa' e 'e Mesas das Câmaras Municipais', contidas, respectivamente, no $\S 2^{\circ}$ do art. 29 , no inciso I do art. 71 e no inciso II do mesmo artigo (71), todos da Constituição do Estado do Espírito Santo". Pleno. Julgado em 25/03/99. Publicado no Diário de Justiça de 07/05/99. Disponível em $<$ http://redir.stf.jus.br/paginadorpub/paginador.jsp?docTP=AC\&docID=347354>, acesso em 22 de dez. 2011.

Ação Direta de Inconstitucionalidade $n^{\circ}$ 2.117-6/Distrito Federal (Medida Liminar), Rel. Min. Maurício Corrêa. Tribunal Pleno do Supremo Tribunal Federal. Julgada em 03/05/00 e publicada no Diário de Justiça de 07/11/03. Disponível em: http://redir.stf.jus.br/paginadorpub/paginador.jsp?docTP=AC\&docID=347443, acesso em 18 de nov. 2011.

Ação Direta de Inconstitucionalidade n 2.631-3/Pará, Rel. Min. Carlos Velloso, julgada em 29/08/02 e publicada no Diário de Justiça de 08/08/03. Disponível em: $<$ http://redir.stf.jus.br/paginadorpub/paginador.jsp?docTP=AC\&docID=266865>, acesso em 18 de dez. 2011.

Agravo Regimental em Recurso Ordinário no 396478 - Fortaleza/Ceará, Rel. Min. Aldir Guimarães Passarinho Júnior. Publicado em sessão de 07/10/2010. Disponível em: <http://www.tse.jus.br/jurisprudencia/inteiro-teor>, acesso em 08 de jan. 2012.

Agravo Regimental em recurso Ordinário nº 415441 - Fortaleza/Ceará, Rel. Min. Aldir Guimarães Passarinho Júnior, acórdão publicado em sessão de 15/09/2010. Disponível em: $<$ http://www.tse.jus.br/jurisprudencia/pesquisa-de-jurisprudencia/jurisprudencia>, acesso em 08 de jan. 2012. 
Agravo Regimental em Recurso Ordinário no 462727/Fortaleza (Ceará), Rel. Min. Marcelo Henrique Ribeiro de Oliveira, publicado no Diário da Justiça Eletrônico do dia 11/04/11, pp. 30-31. Disponível em: 〈http://www.tse.jus.br/jurisprudencia/inteiro-teor>, acesso em 15 de jun. 2011.

Agravo Regimental no Recurso Ordinário $n^{\circ}$ 1614-41.2010.6.16.0000, Rel. Min. Aldir Passarinho Junior. Agravo regimental desprovido, por maioria. Publicado em sessão de 16/11/10. Disponível em: <http://www.tse.jus.br/jurisprudencia/inteiro-teor>, acesso em 03 de dez. 2011.

Agravo Regimental no Recurso Ordinário n 4176-02.2010.6.06.0000 - Classe 37 Fortaleza - Ceará. Rel. Min. Cármen Lúcia. Negado provimento ao Agravo Regimental, v. u., julgado em 03/02/2011. Disponível em: <http://www.tse.jus.br/jurisprudencia/pesquisade-jurisprudencia>, acesso em 03 de dez. 2011.

Agravo Regimental no Recurso Ordinário no 4417-24.2010.6.15.000 - Classe 37 - João Pessoa - Paraíba, Rel. Min. Hamilton Carvalhido. “O Tribunal, por maioria, desproveu o agravo regimental, nos termos do voto do relator. Acórdão publicado na sessão de 09/11/10".

Disponível em: <http://www.tse.gov.br/internet/jurisprudencia/inteiro_teor.htm>, acesso em 04 de ago. 2011.

Apelação Cível com Revisão no 278.905-5/2-00, da Comarca de São Paulo-Fazenda Pública. Rel. Desembargadora Christine Santini. Segunda Câmara de Direito Público do Tribunal de Justiça do Estado de São Paulo, julgado em 18/12/07). Disponível em < http://esaj.tjsp.jus.br/cjsg/getArquivo.do?cdAcordao=2435542>, acesso em 01 de out. 2011.

Apelação no 994.08.164399-9, Rel. Desembargador Nogueira Diefenthäler. $7^{\text {a }}$ Câmara de Direito Público do Tribunal de Justiça do Estado de São Paulo. Julgado em 13/12/10. Disponível em: $<$ https://esaj.tjsp.jus.br/cjsg/getArquivo.do?cdAcordao=4868274\&vlCaptcha=Esxqv >. Acesso em 19 de dez. 2011. 
Consulta $n^{\circ}$ 112026/DF, Rel. Min. Hamilton Carvalhido, Tribunal Superior Eleitoral, sessão de 10.06.2010. Disponível em: 〈http://www.tse.jus.br/jurisprudencia/inteiro-teor>, acesso em 03 de dez. 2011.

Mandado de Injunção nº 670-9 - Espírito Santo. Rel. Originário Min. Maurício Corrêa. Rel. para acórdão Min. Gilmar Mendes. Tribunal Pleno. Julgado em 25/10/07. "O Tribunal, por maioria, nos termos do voto do Relator, conheceu do mandado de injunção e propôs a solução para a omissão legislativa com a aplicação da Lei $n^{\circ} 7.783$, de 28 de junho de 1989, no que couber, vencidos, parcialmente, os Senhores Ministros Ricardo Lewandowski, Joaquim Barbosa e Marco Aurélio, que limitavam a decisão à categoria representada pelo sindicato e estabeleciam condições específicas para o exercício das paralisações. Votou a Presidente, Ministra Ellen Gracie. Não votou o Senhor Ministro Menezes Direito por suceder ao Senhor Ministro Sepúlveda Pertence, que proferiu voto anteriormente. Ausente, justificadamente, a Senhora Ministra Cármen Lúcia, com voto proferido em assentada anterior. Plenário, 25.10.2007". Disponível em: $<$ http://www.stf.gov.br/portal/processo/verProcessoAndamento.asp?numero=712\&classe= MI\&origem=AP\&recurso=0\&tipoJulgamento=M>, acesso em 05 de abr. de 2008.

Mandado de Segurança no 142.463-0/9-00, Rel. designado Desembargador Ivan Sartori. Órgão Especial do Tribunal de Justiça do Estado de São Paulo. Por maioria de votos, conheceram da impetração e, no mérito, por unanimidade, denegaram a ordem. Julgado em 26/09/07. Disponível em: <https://esaj.tjsp.jus.br/cjsg/getArquivo.do?cdAcordao=2399320\&vlCaptcha=jdhnW>. Acesso em 19 de dez. 2011.

Mandado de Segurança ${ }^{\circ}$ 23.550-1/DF, Rel. Min. Marco Aurélio. Rel. para o acórdão: Min. Sepúlveda Pertence. Tribunal Pleno. Julgado em 04/04/01. Disponível em: < http://redir.stf.jus.br/paginadorpub/paginador.jsp?docTP=AC\&docID=85979>, acesso em 28 de ago. 2011.

Med. Caut. em Ação Direta de Inconstitucionalidade 2.238-5/Distrito Federal. Rel. Original Min. Ilmar Galvão. Rel. para o acórdão Min. Carlos Ayres Britto. Tribunal Pleno. No tocante ao artigo 56, caput, cautelar deferida, à unanimidade, nos votos do Relator. Julgado em 09/08/07 e publicado no Diário Oficial da União de 12/09/08. Disponível em 
$<$ http://redir.stf.jus.br/paginadorpub/paginador.jsp?docTP=AC\&docID=547193>， acesso em 31 de out. 2011.

Medida Cautelar em Ação Direta de Inconstitucionalidade no 215-5/Paraíba. Rel. Min. Celso de Mello. Por v.u., deferido em parte o pedido liminar para suspender, até o julgamento final da ação, a vigência do $\S 6^{\circ}$ do artigo 71 da Constituição do Estado da Paraíba e, no $\S 7^{\circ}$ do artigo 13, da mesma Constituição, as expressões "findo o qual, não havendo manifestação, entender-se-á como recomendada a aprovação" e, ainda, no artigo 12 do Ato das Disposições Transitórias da mesma Constituição, as seguintes expressões "Considerando-se como recomendada a sua aprovação se, findo este prazo, não tiver havido manifestação a respeito". Também por unanimidade o Tribunal indeferiu o pedido de liminar quanto ao inciso II, do art. 71, da Constituição do Estado da Paraíba. Julgada em 07/06/90. Disponível em: http://redir.stf.jus.br/paginadorpub/paginador.jsp?docTP=AC\&docID=346256>, acesso em 12 de dez. 2011.

Processo no 0404493-06-1994.8.26.0053. 11ª Vara da Fazenda Pública. Ação Ordinária. Disponível em: $<$ http://esaj.tjsp.jus.br/cpo/pg/show.do?processo.codigo=1HZWZF0CT0000\&processo.for $\mathrm{o}=53$ > . Acesso em 02 de dez. 2011.

Recurso Extraordinário n ${ }^{\circ}$ 132.747-2/Distrito Federal. Relator Min. Marco Aurélio. "Por maioria de votos, em conhecer do recurso e lhe dar provimento, para afastar a declaração de inelegibilidade, vencido o Ministro Carlos Velloso, que dele não conhecia”. Julgado em 17/06/92 e publicado no Diário de Justiça de 07/12/95. Disponível em: <http://www.stf.jus.br/portal/jurisprudencia/listarJurisprudencia.asp?s1=\%28RE\%24\%2ES $\mathrm{CLA} \% 2 \mathrm{E}+\mathrm{E}+132747 \% 2 \mathrm{ENUME} \% 2 \mathrm{E} \% 29+\mathrm{OU}+\% 28 \mathrm{RE} \% 2 \mathrm{EACMS} \% 2 \mathrm{E}+\mathrm{ADJ} 2+132747$ \%2EACMS\%2E\%29\&base=baseAcordaos>, acesso em 07 de jan. 2012.

Recurso Extraordinário nº 633.703/Minas Gerais, Rel. Min. Gilmar Mendes. "Recurso Extraordinário conhecido para: a) reconhecer a repercussão geral da questão constitucional atinente à aplicabilidade da $\mathrm{LC} \mathrm{n}^{\circ} 135 / 2010$ às eleições de 2010, em face do princípio da anterioridade eleitoral (art. 16 da Constituição), de modo a permitir aos Tribunais e Turmas Recursais do país a adoção dos procedumentos relacionados ao exercício de retratação ou declaração de inadmissibilidade dos recursos repetitivos, sempre que as decisões recorridas 
contrariarem ou se pautarem pela orientação ora firmada; b) dar provimento ao recurso, fixando a não aplicabilidade da Lei Complementar $n^{\circ}$ 135/2010 às eleições gerais de 2010". Julgado em 23/03/11 e publicado no diário de Justiça de 18/11/11. Disponível em $<$ http://redir.stf.jus.br/paginadorpub/paginador.jsp?docTP=AC\&docID=629754>, acesso em 19 de dez. 2011.

Recurso Ordinário nº 67033 - Palmas/TO. Rel. Min. Aldir Guimarães Passarinho Junior. Publicado em Sessão de 07/10/10. Disponível em: <http://www.tse.jus.br/internet/jurisprudencia/index.htm>, acesso em 15 de jun. 2011.

Recurso Ordinário no 75179/TO, Rel. Min. Arnaldo Versiani, sessão 08/09/10. Disponível em: <http://www.tse.jus.br/jurisprudencia/pesquisa-de-jurisprudencia>, acesso em 03 de dez. 2011.

Repercussão Geral em Recurso Extraordinário n 597.362-0/Bahia. Rel. Min. Eros Grau. Reconhecida a Repercussão Geral em 20 de março de 2009. Pronunciamento do Min. Marco Aurélio quanto à existência de Repercussão Geral em 25 de março de 2009. Disponível em:

http://redir.stf.jus.br/paginadorpub/paginador.jsp?docTP=AC\&docID=595603>, acesso em 14 de dez. 2011.

\section{Sites Consultados:}

Assembleia da República de Portugal. Disponível em: <http://www.parlamento.pt/Legislacao/Paginas/ConstituicaoRepublicaPortuguesa.aspx>, acesso em 07 de jan. 2012.

Biblioteca Virtual de Direitos Humanos da Universidade de São Paulo. Disponível em <http://www.direitoshumanos.usp.br>, acesso em 07 de jan. 2012.

Câmara dos Deputados. Disponível em: < http://www2.camara.gov.br/>, acesso em 17 de jan. 2011 e, especificamente, Coordenação de Relacionamento, Pesquisa e Informação (Corpi) do Centro de Documentação e Informação (Cedi) da Câmara dos Deputados, Anexo II. E-mail: informa.cedi@camara.gov.br. Acesso em 17 de jan. 2011. 
Câmara Municipal de São Paulo. Disponível em: < http://www.camara.sp.gov.br/index.php>, acesso em 16 de mar. 2011.

Conseil Constitutionnel. Disponível em: <http://www.conseil-constitutionnel.fr/conseilconstitutionnel/francais/page-d-accueil.1.html>, acesso em 07 de jan. 2012.

Escola de Governo. Disponível em: <http://www.escoladegoverno.org.br/biblioteca/125declaracao-1789>, acesso em 13 jul. 2011.

IBGE. Disponvível em: 〈http://www.ibge.gov.br/estadosat/index.php>, acesso em 30 de dez. 2011.

Ouvidoria do Parlamento - Câmara Municipal de São Paulo. Disponível em: <http://www.camara.sp.gov.br/index.php>, acesso em 16 de mar. 2011.

Planalto. Disponível em: <http://www.planalto.gov.br>, acesso em 06 de jan. 2012.

Senato della Repubblica. Disponível em: <http://www.senato.it/documenti/repository/costituzione.pdf>, acesso em 26 de nov. 2011.

Supremo Tribunal Federal. Disponível em: 〈http://www.stf.jus.br〉, acesso em 05 de abr. de 2008 .

Tribunal de Contas do Distrito Federal. Disponível no site: <http://www.tc.df.gov.br/web/site/biblioteca-de-documentos>, acesso em 10 de jan. 2012.

Tribunal de Contas do Estado de Goiás. Disponível em: <http://tcenet.tce.go.gov.br/Downloads/Arquivos/000100/Lei\%20organica\%203.0.pdf>, acesso em 10 de jan. 2012.

Tribunal de Contas do Estado de Mato Grosso. Disponível em: <http://www.tce.mt.gov.br/legislacao?categoria=4>, acesso em 10 de jan. 2012;

Tribunal de Contas do Estado do Mato Grosso do Sul. Disponível em: <http://www.tce.ms.gov.br/portal/legislacao_servico_consulta>, acesso em 10 de jan. 2012;

Tribunal de Contas do Município de São Paulo. Disponível em: $<$ http://www.tcm.sp.gov.br> 
Tribunal de Contas dos Municípios do Estado da Bahia. Disponível em: <http://www.tcm.ba.gov.br/leiorg.shtml>, acesso em 17 de nov. 2011.

Tribunal de Contas dos Municípios do Estado de Goiás. Disponível em: <http://www.tcm.go.gov.br>, acesso em 10 de jan. 2012.

Tribunal de Contas dos Municípios do Estado do Pará. Disponível em: <http://www.tcm.ba.gov.br/leiorg.shtml>, acesso em 17 de nov. 2011.

Tribunal de Justiça do Estado de São Paulo. Disponível em: 〈http://www.tj.sp.gov.br>, acesso em 19 de dez. 2011.

Tribunal Superior Eleitoral. Disponível em: <http://www.tse.gov.br>, acesso em 04 de ago. 2011.

\section{Outros:}

Balanço Geral ao Exercício de 1991, Prefeita Luíza Erundina de Souza. Parecer Prévio nos autos do TC n 72.003.008.92-00. Rel. Conselheiro Eurípedes Sales. Julgado em 24 de junho de 1992. V.u. contrário à aprovação das contas do Executivo. pp. 432-465.

Balanço Geral ao Exercício de 2000, Prefeito Celso Roberto Pitta do Nascimento. Parecer Prévio nos autos do TC no 72.001.839.01-83. Rel. Conselheiro Substituto Djalma Donato. Voto em separado proferido pelo Conselheiro Revisor, Antonio Carlos Caruso. Julgado em 24 de junho de 1992. V.u. contrário à aprovação das contas do Executivo. pp. 522-523.

Balanço Geral ao Exercício de 2010, Prefeito Gilberto Kassab. Parecer Prévio nos autos do TC n ${ }^{\circ}$ 72.000.923.11-24, Rel. Conselheiro Antonio Carlos Caruso. Julgado em 28 de junho de 2011. v.u. favorável à aprovação das contas do Executivo.

Declaração Universal dos Direitos do Homem e do Cidadão de 1789. Disponível em: <http://www.direitoshumanos.usp.br/index.php/Documentos-anteriores-à-criação-daSociedade-das-Nações-até-1919/declaracao-de-direitos-do-homem-e-do-cidadao1789.html>, acesso em 05 de jan. 2012.

Entrevista Ellen Gracie Northfleet. Revista Veja. Edição 2232. São Paulo: Abril, 31 de agosto, 2011. p. 22. 
IBGE. Finanças Públicas nas Cidades. Os sites para as cidades de Porto Alegre, Belo Horizonte, Rio Branco e Macapá são, respectivamente: Disponível em: <http://www.ibge.gov.br/cidadesat/link.php?uf=rs> <http://www.ibge.gov.br/cidadesat/link.php?uf=mg>, <http://www.ibge.gov.br/cidadesat/link.php?uf=ac> <http://www.ibge.gov.br/cidadesat/link.php?uf=ap>, acesso em 30 de dez. 2011.

IBGE. População nos Estados. Disponvível em: <http://www.ibge.gov.br/estadosat/index.php>, acesso em 30 de dez. 2011.

Notícias do STF. Disponível em: <http://stf.jus.br/portal/cms/verNoticiaDetalhe.asp?idConteudo=195649>, acesso em 07 de jan. de 2012.

Parecer Prévio à prestação de Contas da Prefeitura da Cidade do Rio de Janeiro: exercício de 2010. Tribunal de Contas do Rio de Janeiro. Rel. Conselheiro Nestor Guimarães Martins da Rocha, julgado em 11 de julho de 2011. Rio de Janeiro: TCM-RJ, 2011. 